UNIVERSIDADE DE SÃO PAULO

SANDRO JOSÉ MONTEIRO

ESTUDO DO PROBLEMA DA COMUNICAÇÃO EM TEMPO REAL COM O CONSUMIDOR NA SITUAÇÃO DE INTERRUPÇÃO DE FORNECIMENTO DE ENERGIA ELÉTRICA EM DIAS CRÍTICOS 



\title{
ESTUDO DO PROBLEMA DA COMUNICAÇÃO EM TEMPO REAL COM O CONSUMIDOR NA SITUAÇÃO DE INTERRUPÇÃO DE FORNECIMENTO DE ENERGIA ELÉTRICA EM DIAS CRÍTICOS
}

\author{
Dissertação Apresentada à Escola \\ Politécnica da Universidade de São \\ Paulo para obtenção do título de \\ Mestre em Engenharia Elétrica
}

Área de Concentração:

Sistemas de Potência

Orientador: Prof. Dr.

Carlos Márcio Vieira Tahan. 


\section{AUTORIZO A REPRODUÇÃO TOTAL OU PARCIAL DESTE TRABALHO, POR QUALQUER MEIO CONVENCIONAL OU ELETRÔNICO, PARA FINS DE ESTUDO E PESQUISA, DESDE QUE CITADA A FONTE.}

Este exemplar foi revisado e alterado em relação à versão original, sob responsabilidade única do autor e com a anuência de seu orientador.

São Paulo, 13 de Abril de 2007.

Assinatura do autor

Assinatura do orientador

\section{FICHA CATALOGRÁFICA}

Monteiro, Sandro José.

Estudo do problema da comunicação em tempo real com o consumidor na situação de interrupção de fornecimento de energia elétrica em dias críticos / S.J. Monteiro;

-- ed. rev. -- São Paulo, 2007.

$151 \mathrm{f}$.

Dissertação (Mestrado) - Escola Politécnica da Universidade de São Paulo. Departamento de Engenharia de Energia e Automação Elétricas.

1. Energia Elétrica (Qualidade). 2. Transmissão de Energia Elétrica. 3. Tempo real. Comunicação. I. Universidade de São Paulo. Escola Politécnica. Departamento de Energia e Automação Elétricas. II.t. 


\section{DEDICATÓRIA}

Ao Matteo, meu filho. 


\section{AGRADECIMENTOS}

Agradecimentos ao Prof. Dr. Carlos Márcio Vieira Tahan pela dedicação de seu tempo ao orientar esta pesquisa, guiando e norteando passos antes difusos.

Agradecimentos ao Prof. Dr. Marcos Gouvêa, ao Prof. Dr. Nelson Kagan e Prof. Dr. Marcelo Pelegrini por pautarem, complementarem e sugerirem novos caminhos para esta pesquisa.

Agradecimentos aos Profs. Dr. Miguel Edgar Moraes Udaeta, Dr. José Aquiles Baesso Grimoni, Dr. Luiz Cera Zanneta Junior, Dr. Dorel Soares Ramos, todos eles do PEA, pelas disciplinas cursadas.

Agradecimentos a Universidade de São Paulo, a Escola Politécnica, e ao Departamento de Energia e Automação Elétrica, incluindo todos os colaboradores dessa destacada instituição.

Agradecimentos para a empresa DAMOVO, pelo acesso às informações técnicas de produtos, conceitos e soluções que compõem esta pesquisa, além da vivência prática nos assuntos aqui tratados.

Agradecimentos ao colega Sr. Esmeraldino da Silveira Junior, pelo auxílio na obtenção dos dados deste estudo, e também pela colaboração com a sua experiência prática vivida em centros de teleatendimento.

Agradecimentos para a empresa CPFL Paulista, com especial atenção aos Srs. Milton Biral Filho e Ronaldo Borges Franco pelo fornecimento e contribuição com dados que possibilitaram o estudo de caso.

Agradecimentos à família, pelos caminhos conjuntamente trilhados até este momento.

Agradecimentos à esposa Michele, pelo incentivo e exemplo. 


\section{RESUMO}

MONTEIRO, Sandro José. Estudo do problema da comunicação em tempo real com o consumidor na situação de interrupção de fornecimento de energia elétrica em dias críticos. 2007. 151 f.. Dissertação (Mestrado). Departamento de Engenharia de Energia e Automação Elétricas. Escola Politécnica da Universidade de São Paulo, São Paulo, 2007.

Condições meteorológicas adversas como tempestades, descargas atmosféricas e chuvas de granizos têm o potencial de danificar simultaneamente e seriamente muitos circuitos da rede de distribuição aérea. Esse tipo de dano só será solucionado quando fisicamente uma equipe estiver no local para repará-lo, o que acontecerá somente após localizar o defeito. Portanto, grandes tempestades podem resultar em um número enorme de consumidores desligados, levando horas ou até alguns dias para total restabelecimento. Enquanto isso, os consumidores preocupados tentam acessar os serviços de atendimento telefônicos, contudo sem sucesso devido ao congestionamento inevitável das linhas de comunicação. Esse fato, e outros mais apresentados, evidenciam que a excelência na comunicação com o consumidor de energia elétrica ainda se constitui em um desafio no Brasil. A boa notícia é que existem meios e possibilidades de se evoluírem os sistemas de informações atualmente implantados nas distribuidoras. Este trabalho caracteriza esse problema da comunicação em tempo real com o consumidor de energia elétrica durante as interrupções de grande abrangência na rede de distribuição em seus dias críticos, sugerindo tecnologias que aprimorem a solução deste problema. O tema é abordado de forma multidisciplinar, e organizado sob cinco dimensões e contextos distintos: dos aspectos legais, da comunicação em tempo real, da tecnologia de informação, da qualidade de serviço, e da engenharia de tráfego. O trabalho também propõe uma metodologia para previsão da quantidade de chamadas e ou contatos do consumidor para com a concessionária de energia elétrica nos Dias Críticos, procurando abordar e caracterizar todas as variáveis dessa problemática.

Palavras chave: Energia Elétrica. Distribuição. Qualidade de Energia. Comunicação. Regulação. Tecnologia da Informação. 


\begin{abstract}
MONTEIRO, Sandro José. Investigation of the real time communication problem with consumers during energy supply interruption in critical days. 2007. 151 f.. Dissertação (Mestrado). Departamento de Engenharia de Energia e Automação Elétricas. Escola Politécnica da Universidade de São Paulo, São Paulo, 2007.

Severe weather conditions such as hurricanes, lightning storms, etc. have the potential to seriously damage electric utility transmission and distribution systems. This type of damage will disrupt electrical service until the physical facilities can be replaced or repaired. Then large storms can result in a massive number of customer outages, sometimes taking from hours to days to repair. In the meantime, customers can be left without electric service during difficult conditions such as extreme cold or extreme heat - trying to access attendance services and information, without any success because the inevitable congestion in telephones lines. This fact, and others, illustrates that the excellence into relationship with electrical energy consumers still is a challenge in Brazil. The good news that there are means to upgrade existing information systems installed in the distribution sector. This work examines that communication problem with electrical energy consumer during interruptions in critical days, and suggests technologies to answer that problem. The whole theme is faced in a multidisciplinary way, and organized under five contexts: legal aspects, real time communication, information technology, quality of service, and traffic engineering. Further more, this work proposes a basic methodology to preview the amount of consumers calls in those critical days, looking for all variables.
\end{abstract}

Keywords: Electrical Energy. Distribution. Energy Quality. Communication. Regulation. Information Technology. 


\section{LISTA DE FIGURAS}

Figura 1: Reporte de falta de energia elétrica na FPL via vebsite .....................................2 27

Figura 2: Tela de Script HTML da FPL, logo depois de acessado o link da figura anterior. .. 28

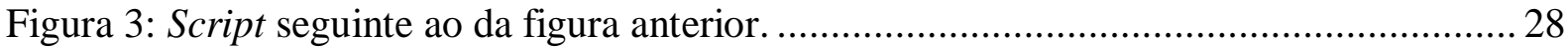

Figura 4: Formulário na Web da NIE para submissão de reclamações de falta de energia..... 30

Figura 5: Web Services da Scottish Power. ....................................................................... 31

Figura 6: Conscientização via Internet de consumidores da ConEdison, referente a dias de

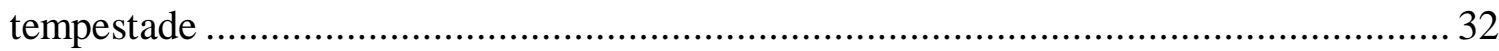

Figura 7: Exemplo de arquitetura CRM utilizando PABX integrado via CTI com telas do atendente.

Figura 8: Exemplo de arquitetura WFM utilizando um PABX, um Servidor de E-mail e de

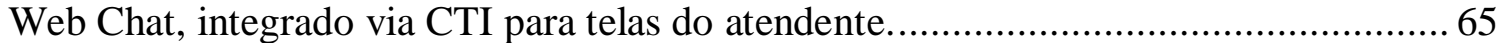

Figura 9: Exemplo de website integrado com as múltiplas mídias......................................67

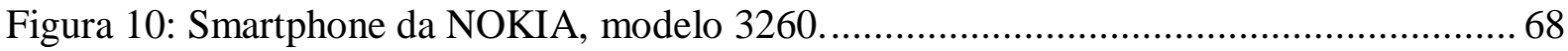

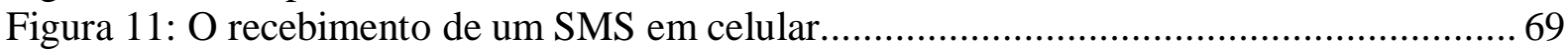

Figura 12: Pocket PC que suporta MMS e Internet Móvel (iPACK 6900) ........................... 71

Figura 13: Click-to-dial via Browser integrado em centros de atendimento com SIP e CTI. . 72

Figura 14: Exemplo de arquitetura Web para integração de voz e dados, via XML.............. 73

Figura 15: Processo de atendimento em um PABX DAC com roteamento por habilidades... 75

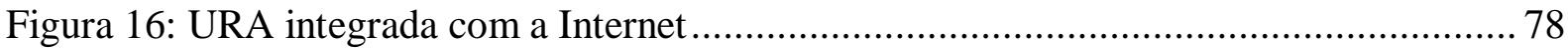

Figura 17: Discador automático de alta capacidade em formato de gabinete ...................... 79

Figura 18: Automação de recebimento de SMS a partir de plataformas SCADA. ................ 82

Figura 19: Exemplo de Web Chat entre consumidor e atendente, com sugestão de resposta por

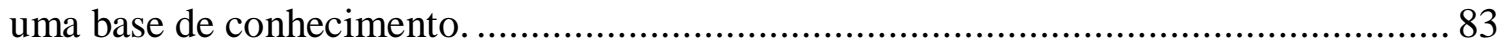

Figura 20: Demonstração de Agente Virtual em terminal celular sobre a Internet Móvel..... 84

Figura 21: Exemplo de página em website para requisição de Rechamada na Web............. 85

Figura 22: Exemplo de duas Centrais de Teleatendimento Operando em Rede. .................... 89 


\section{LISTA DE GRÁFICOS}

Gráfico 1: Índice ANEEL de Satisfação do Consumidor (IASC) e os Benchmarks Internacionais.

Gráfico 2: Porcentual de Consumo de Energia por Classe e Porcentual de Consumidores em Setembro de 2006, respectivamente, para o Estado de São Paulo. 60

Gráfico 3: Qualificação de aplicações multimídia em centros de atendimento, conforme

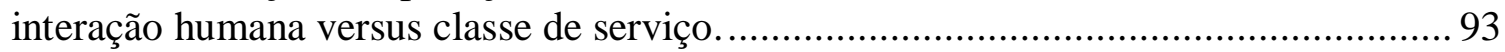

Gráfico 4: Exemplo de Distribuição de Poisson no Tráfego Telefônico ............................... 98

Gráfico 5: Exemplo de Distribuição Exponencial Negativa ............................................. 100

Gráfico 6: Exemplo de Curva Ajustada para Distribuição Gama de uma Curva Histórica ... 114

Gráfico 7: Exemplo de curva de dispersão da relação $\beta$ em função do número total de

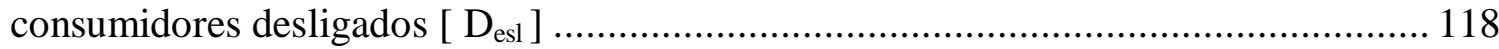

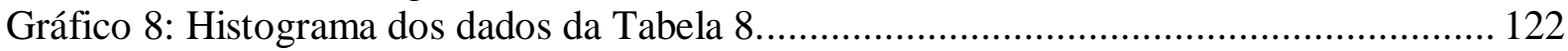

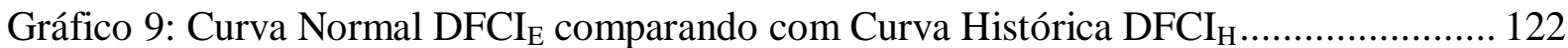

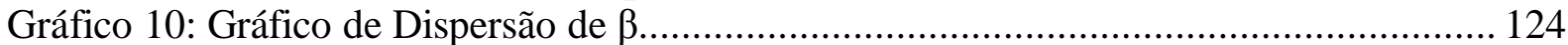

Gráfico 11: Comparativo da previsão de Quantidade de Chamadas Oferecidas (COf) em um

Dia Crítico para cinco cenários diferentes............................................................. 126 


\section{LISTA DE TABELAS}

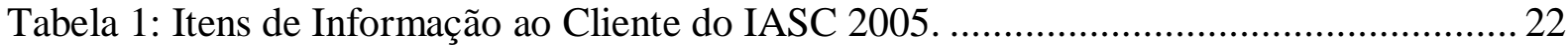

Tabela 2: Pesquisa Nacional por Amostra de Domicílios do IBGE..................................... 57

Tabela 3: Metas Anuais de Índice de Nível de Serviço da ANEEL......................................90

Tabela 4: Metas Anuais de Índice de Abandono da ANEEL.............................................. 91

Tabela 5: Metas Anuais de Índice de Chamadas Ocupadas da ANEEL................................ 92

Tabela 6: Comparação de Modelos de Tráfego Telefônico ................................................... 102

Tabela 7: Classificação das Variáveis do Modelo ................................................................ 107

Tabela 8: Distribuiçãa Histórica de Freqüências da Quantidade (diária) de Circuitos

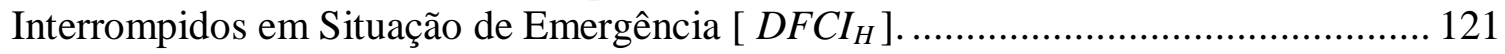

Tabela 9: Resumo dos Dados para Cálculos de Engenharia de Tráfego. ............................. 127

Tabela 10: Resultados de Engenharia de Tráfego de Acordo com os Modelos Adotados .... 127

Tabela 11: Dados Históricos de Quantidade de Chamadas Atendidas em Dias Críticos ...... 128

Tabela 12: Cálculo de Posições de Atendimento Para Dias Típicos ................................... 130

Tabela 13: Proposta de Priorização de Investimentos em Novos Serviços de Atendimento nos Contact Centers das Distribuidoras.......................................................................... 132

Tabela 14: Quantidade total diária de Circuitos Interrompidos em situação de emergência [

$\mathrm{CIH}$ ], apurado no período de 12 meses .................................................................. 146

Tabela 15: Chamadas Atendidas [ CA ], apurado no período de 12 meses .......................... 147

Tabela 16: Índice de Chamadas Ocupadas [ ICO ], apurado no período de 12 meses .......... 148

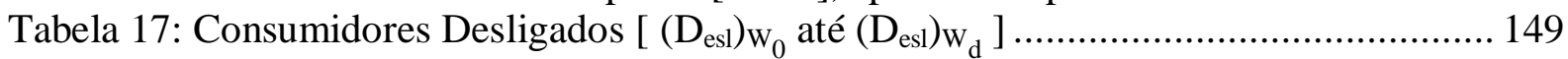

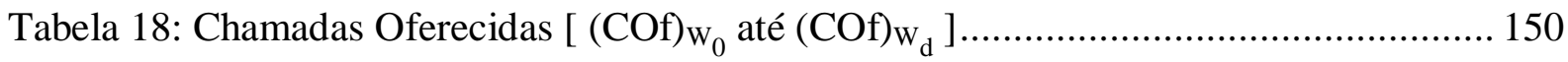

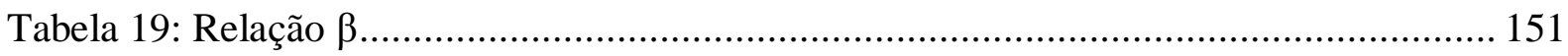




\section{LISTA DE SÍMBOLOS}

A

AP

c

CA

$\mathrm{CI}_{\mathrm{H}}$

CO

COf

$\mathbf{W}_{\mathrm{d}}$

D $_{\text {esl }}$

DFCI $_{E}$

DFCI $_{H}$

e

E( DFCI $\mathbf{I}_{\mathbf{E}}$ Média da Freqüência de Interrupções de Situação de Emergência;

$E_{1}$

$E_{2}$

Taxa média de utilização do sistema telefônico, ou tráfego médio em um sistema telefônico [Erlang];

Função probabilidade da chegada de chamadas em um sistema telefônico, segundo uma Distribuição de Poisson;

Quantidade de chamadas que entram em um sistema telefônico;

Chamadas Atendidas, sendo a quantidade diária de chamadas telefônicas atendidas eletronicamente ou não eletronicamente na Central de Teleatendimento;

Quantidade Histórica de Circuitos Interrompidos em Situação de Emergência;

Chamadas Ocupadas, sendo a quantidade diária de chamadas telefônicas que não puderam ser completadas e atendidas por falta de capacidade da Central de Teleatendimento;

Chamadas Oferecida, sendo as ligações telefônicas, não bloqueada por restrições advindas da operadora de serviço telefônico, que visa o acesso a uma Central de Teleatendimento;

Número inteiro representando o total de dias críticos e não críticos apurados para o estudo;

Para cada classe de tensão primária da distribuidora, é o mais provável número total de Consumidores Desligados;

Distribuição Esperada de Freqüências da Quantidade de Circuitos Interrompidos em Situação de Emergência;

Distribuição Histórica de Freqüências da Quantidade de Circuitos Interrompidos em Situação de Emergência;

Número neperiano;

Proporção de tempo que um sistema telefônico está totalmente ocupado; é também em termos de chamadas, a proporção de chamadas perdidas (ou não atendidas) [\%];

Probabilidade de espera ou atraso em um sistema telefônico, comumente chamada de Nível de Serviço [\%]; 
Fator K Representa a adequação de um padrão desconhecido de chegada de chamadas em um sistema telefônico para um padrão aleatório exponencial, especialmente aquele que obedece a Distribuição de Poisson;

Fator $\mathbf{P}$ Representa um padrão comportamental da população consumidora da região de concessão da distribuidora estuda;

Índice da classe de tensão dos circuitos primários, variando de 1 até $\mathbf{j}$;

IAb

ICO

INB

Índice de Abandono, é a razão entre o total de chamadas abandonadas em um sistema telefônico e o total de chamadas recebidas por atendentes [\%];

Índice diário de Chamadas Ocupadas, devido ao congestionamento das linhas de acesso da Central de Teleatendimento da distribuidora de energia, informadas pela operadora de serviço telefônico [\%];

Índice de Nível de Serviço Básico, é a razão entre o total de chamadas atendidas em até 30 segundos em um sistema telefônico e a soma obtida pelo total de chamadas atendidas, o total de chamadas abandonadas e o total de chamadas ocupadas [\%];

$j$

Número total de classes de tensão de circuitos primários da concessionária;

$\boldsymbol{k}$

Quantidade de linhas telefônicas necessárias para um sistema telefônico;

$m$

Quantidade de servidores em um sistema de atendimento;

$\mathrm{NC}_{\mathbf{m}}$

Número médio de consumidores por circuito e classe de tensão primária;

$q$

Número inteiro multiplicador do desvio padrão $\varphi$

$S P$

Função probabilidade de atendimento de chamadas em um sistema telefônico, segundo uma Distribuição Exponencial Negativa;

T Tempo médio referente ao período de restauração de circuitos primários interrompidos em situação de emergência [minutos];

$\mathbf{t}_{\mathbf{a}} \quad$ Intervalo de tempo entre a chegada de chamadas em um sistema telefônico [minutos];

t $\quad$ Tempo de atendimento das chamadas de um sistema telefônico [s];

TMA Tempo Médio de Atendimento, é a razão entre o tempo total despendido para o atendimento em um sistema telefônico, e o total de chamadas atendidas [s];

TME Tempo Médio de Espera, é a razão entre o tempo total de espera em um sistema telefônico, e o total de chamadas em espera no mesmo período [s];

TSF Probabilidade de atraso exceder o TME [\%];

$\mathbf{V E}_{\mathbf{C o f}} \quad$ Volume Esperado de Chamadas Oferecidas para um Dia Crítico; 
VMax $_{\text {Cof }}$ Volume Máximo Esperado de Chamadas Oferecidas para um Dia Crítico;

VMed $_{\text {Cof }} \quad$ Volume Médio Esperado de Chamadas Oferecidas para um Dia Crítico;

VMax $_{\text {COf DIAS TIPICOS }}$

Volume Máximo Esperado de Chamadas Oferecidas para um Dia Típico;

\section{VMed $_{\text {COf DIAS TIPICOS }}$}

Volume Médio Esperado de Chamadas Oferecidas para um Dia Típico;

W Determinado dia crítico ou não crítico da operação da rede de distribuição primária da concessionária de estudo;

$\alpha$

Quantidade de posições de atendimento em um sistema telefônico;

$\beta$ Relação entre a quantidade total de Chamadas Oferecidas e o número total de Consumidores Desligados;

$\lambda \quad$ Média da Distribuição de Poisson, ou a taxa média de chegada de chamadas em um sistema telefônico [chamadas/minuto];

$\boldsymbol{\mu} \quad$ Inverso do tempo médio de atendimento de um sistema telefônico $\left[\mathrm{s}^{-1}\right]$;

$\boldsymbol{\rho} \quad$ Taxa de utilização do sistema de sistemas telefônicos, comumente chamado de tráfego telefônico [Erlang];

$\boldsymbol{\sigma}\left(\mathbf{D F C I}_{\mathbf{E}}\right)$ Desvio Padrão da Freqüência de Interrupções de Situação de Emergência;

$\varphi$ Desvio padrão do Fator $\mathbf{P}$. 


\section{SUMÁRIO}

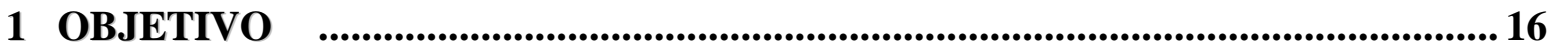

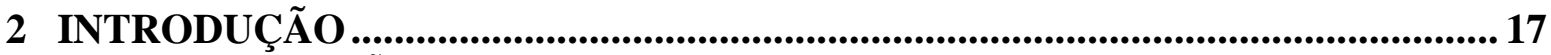

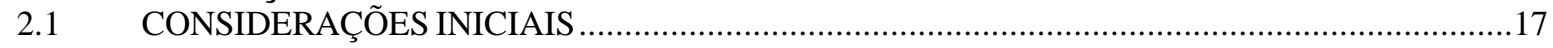

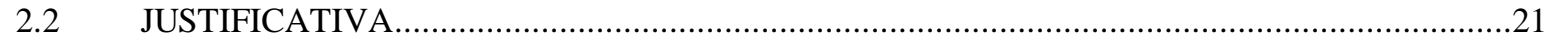

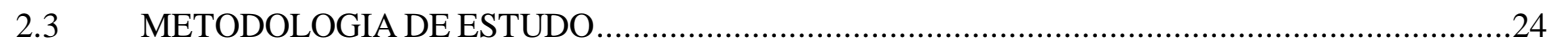

3 O ESTADO DA ARTE DA COMUNICAÇÃO DURANTE EMERGÊNCIAS........26

3.1 DISPONIBILIZAÇÃO DE INFORMAÇÕES EM TEMPO REAL ………………………………...26

3.2 A GESTÃO DAS INFORMAÇÕES NAS DISTRIBUIDORAS ......................................................33

3.3 A GESTÃO DA TECNOLOGIA DE INFORMAÇÃO ………………………………………......36

3.4 OS PLANOS DE RESPOSTA A EMERGÊNCIAS ENERGÉTICAS ………………………….......37

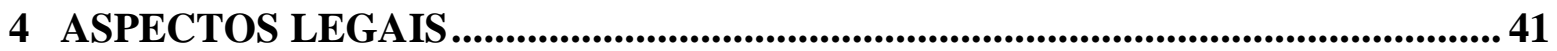

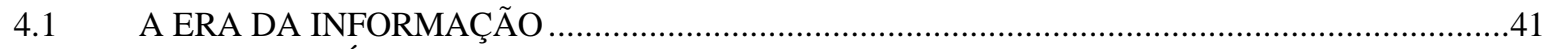

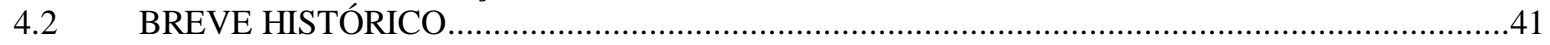

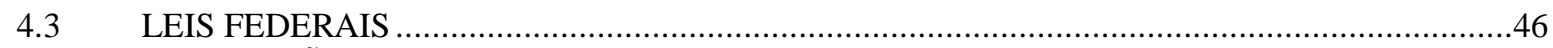

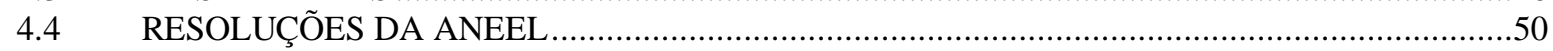

5 ALGUNS ASPECTOS DA COMUNICAÇÃO EM TEMPO REAL ........................55

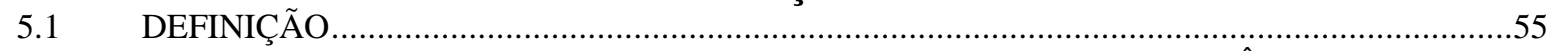

5.2 O COMPORTAMENTO DO CONSUMIDOR: MOBILIDADE E CONVERGÊNCIA .....................56

5.3 OS VEÍCULOS DE COMUNICAÇÃO CERTOS PARA CADA PÚBLICO......................................58

5.4 A MENSAGEM E A LINGUAGEM DE COMUNICAÇÃO …………………………………...59

5.5 A RESPOSTA PRÓ-ATIVA ÀS SITUAÇÕES DE EMERGÊNNCIA.........................................................60

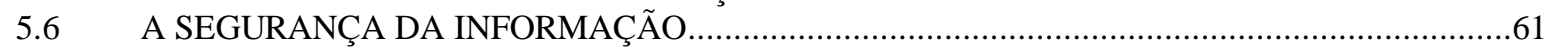

5.7 O MARKETING ONE TO ONE VERSUS MARKETING DE MASSA ………………………....62

6 O CONTEXTO DA TECNOLOGIA DA INFORMAÇÃO A SERVIÇO DA COMUNICAÇÃO ....................................................................................................64

$6.1 \quad$ PRINCIPAIS TECNOLOGIAS DE INFORMAÇÃO………………………………………....64

6.2 PRINCIPAIS APLICAÇÕES NOS CONTACT CENTERS ....………………………………….....73

6.3 OS CENTROS DE ATENDIMENTO EM REDE …………………………………………....86

7 O CONTEXTO DA QUALIDADE DE SERVIÇO ........................................................90

7.1 AS MÉTRICAS DE QUALIDADE DE ATENDIMENTO SEGUNDO A ANEEL …………….....90

7.2 CLASSIFICAÇÃO DOS SERVIÇOS DE ATENDIMENTO ……………………………………....92

7.3 QUALIDADE DE SERVIÇOS NA INFRA-ESTRUTURA DE COMUNICAÇÃO...........................94

8 O CONTEXTO DA ENGENHARIA DE TRÁFEGO TELEFÔNICO.......................97

8.1 OBJETIVOS DO DIMENSIONAMENTO DE TRÁFEGO TELEFÔNICO........................................97

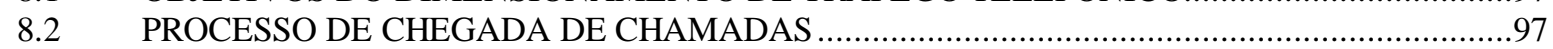

8.3 PADRÃO DE ATENDIMENTO DE CHAMADAS ………………………………………….....99

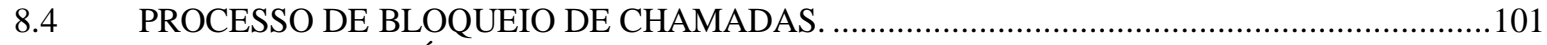

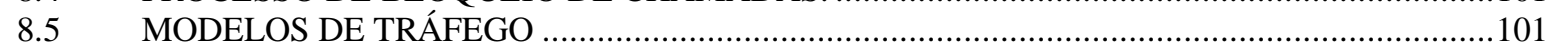

9 PROPOSTA DE PREVISÃO DE CHAMADAS OFERECIDAS PARA DIAS

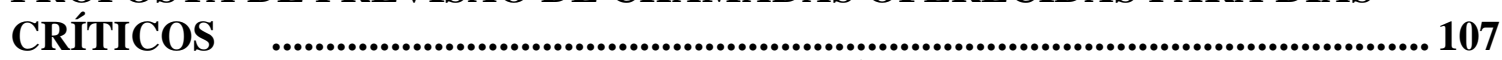

9.1 IDENTIFICAÇÃO E CLASSIFICAÇÃO DAS VARIÁVEIS ………………………………....107

9.2 ESTUDO DE CASO PARTICULAR ……………………………………………………...111

9.3 MODELAMENTO ESTATÍSTICO DAS CHAMADAS OFERECIDAS …………………………...112

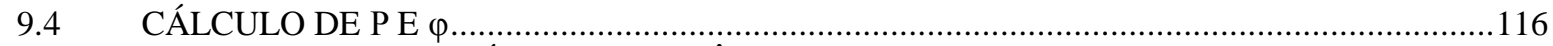

9.5 ENGENHARIA DE TRÁFEGO TELEFÔNICO........................................................................118

10 APLICAÇÃO DO MÉTODO PROPOSTO ......................................................... 121

10.1 MODELAMENTO ESTATÍSTICO DAS CHAMADAS OFERECIDAS ……………………......121

10.2 ENGENHARIA DE TRÁFEGO TELEFÔNICO.................................................................127

11 DISCUSSÃO DOS RESULTADOS....................................................................128

11.1 VALIDAÇ̃̃OO DO MODELAMENTO ESTATÍSTICO DAS CHAMADAS OFERECIDAS …....128

11.2 ENGENHARIA DE TRÁFEGO TELEFÔNICO.......................................................................128

12 CONSIDERAÇÕES FINAIS .................................................................................. 131 


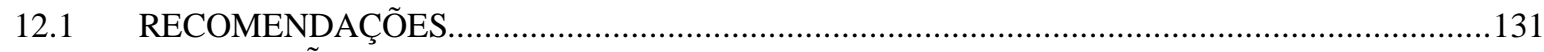

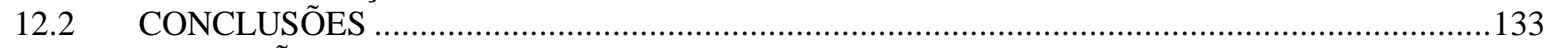

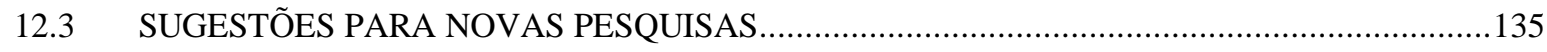

13 REFERÊNCIAS .............................................................................................. 137

APENDICE A

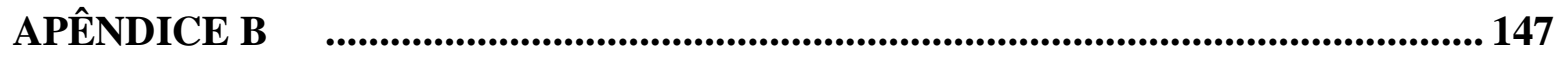

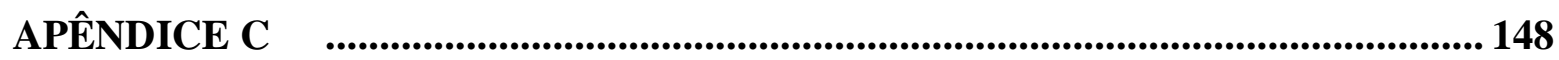

APENDICE D

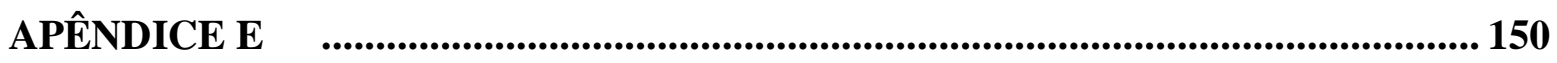

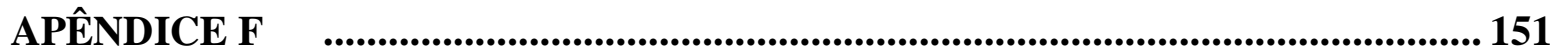




\section{OBJETIVO}

Este trabalho visa à caracterização do problema da comunicação em tempo real com o consumidor de energia elétrica durante as interrupções de grande abrangência na rede de distribuição, ou seja, em seus dias críticos, descrevendo o estado da arte, além de identificar e sugerir processos e tecnologias que aprimorem a solução deste problema que as concessionárias de distribuição enfrentam.

O trabalho visa também propor uma metodologia para previsão do volume de chamadas e ou contatos do consumidor para com a concessionária de energia elétrica nos dias críticos, procurando abordar e caracterizar todas as variáveis dessa problemática. Com base nos resultados dessa previsão é calculada, através de métodos tradicionais de engenharia de tráfego telefônico, a quantidade requerida de linhas telefônicas e posições de atendimento na Central de Teleatendimento de uma distribuidora. 


\section{INTRODUÇÃO}

\subsection{CONSIDERAÇÕES INICIAIS}

Segundo a Resolução № 24 de 27 de Janeiro de 2000 da Agência Nacional de Energia Elétrica (ANEEL), uma Interrupção de Longa Duração é toda interrupção do sistema elétrico com duração maior ou igual a 3 minutos. Uma Interrupção de Situação de Emergência é a interrupção motivada por caso fortuito ou de força maior, a ser comprovada documentalmente pela concessionária de distribuição, desde que não se caracterize como de sua responsabilidade técnica, por falta de manutenção ou de investimentos em seu sistema. Um Dia Crítico é o dia em que a quantidade de ocorrências, associadas à Interrupção em Situação de Emergência, em um determinado conjunto de unidades consumidoras, supera a média acrescida de três desvios padrões dos valores diários. A média e o desvio padrão a serem usados serão os relativos aos 24 meses anteriores ao mês em curso.

Uma Central de Teleatendimento (CTA), segundo a Resolução № 57 de 12 de Abril de 2004 da ANEEL, é a unidade composta por estruturas física e de pessoal adequadas, que tem por objetivo centralizar o recebimento de ligações telefônicas, distribuindo-as automaticamente aos atendentes, possibilitando o atendimento do solicitante pela concessionária.

Supõe-se agora uma CTA de concessionária de distribuição de energia elétrica, dimensionada e construída conforme a Resolução № 57/2004:

- Empresa que se enquadra no Grupo I de Concessionárias, ou seja, que tenha acima de 1.150.000 consumidores;

- Número telefônico único divulgado ao consumidor, do tipo ligação gratuita, com disponibilidade de 24 horas diárias;

- Unidade de Resposta Audível (URA), que tem a função de segmentar e classificar as chamadas que entram em um número único, e depois transferir para as Posições de Atendimento (PA). As chamadas devido à interrupção de fornecimento de emergência são classificadas de acordo com Anexo I da Resolução № 57 ;

- Central Telefônica PABX com função Distribuidor Automático de Chamadas (DAC), operando 24 horas por dia;

- Um Índice de Nível de Serviço Básico ${ }^{1}$ (INB) de 85\%;

- Tempo Médio de Atendimento (TMA) de 120 segundos;

\footnotetext{
${ }^{1}$ Ver definições de INB, TMA, TME, IAb, IÇO no Capítulo 7 deste trabalho.
} 
- Tempo Médio de Espera (TME) na fila de 30 segundos;

- Índice de Abandono (IAb) na fila de espera de 10\%;

- Taxa de repetição de chamadas de $10 \%$, ou seja, igual a IAb;

- Índice de Chamadas Ocupadas (ICO) de 15\%;

- Uma taxa média de chegada de chamadas sendo 2.500 chamadas por hora.

O porte deste tipo de CTA se calcula tradicionalmente pelas Equações de Erlang (como será visto mais no decorrer da dissertação). Para um Dia Típico, definido pela Resolução № 57/2004 como sendo o dia que apresenta volume de chamadas recebidas que não ultrapassa a $20 \%$ em relação à média dos últimos 4 dias correspondentes em semanas anteriores, com apuração realizada individualmente por dia da semana, será preciso no mínimo um PABX DAC de: 77 linhas com a operadora de serviço telefônico; e 89 posições de atendimento (PA).

Considerando agora a eventualidade de uma série de eventos simultâneos de Interrupção de Emergência na rede de distribuição primária nessa concessionária, nas seguintes condições:

- Um Dia Crítico convencional, quando ocorre um acréscimo da ordem de $100 \%$ na demanda normal de ligações para a CTA; nessas condições, a quantidade de Posições de Atendimento (PA) deve subir para 173 para manter o Índice de Nível de Serviços Básico (INB) em 85\%;

- Um Dia Crítico excepcional, quando pode ocorrer um acréscimo da ordem de até $300 \%$ na demanda normal de ligações para a CTA; nessas condições, a quantidade de Posições de Atendimento (PA) deve subir para 256 para manter o Índice de Nível de Serviços Básico (INB) em 85\%.

Para um Dia Crítico convencional, entre as medidas pró-ativas do supervisor da CTA geralmente encontra-se:

- De forma antecipada prever, para os períodos chuvosos do ano, posições de atendimento extras;

- Convocar, logo depois de percebido o fato, um efetivo extra de posições de atendimento, como por exemplo, atendentes previstos inicialmente para outro turno;

- Acelerar a conversação com o consumidor, visando reduzir o Tempo Médio de Atendimento (TMA);

- Tornar disponíveis para atendimento emergencial todas as posições de atendimento que atendem prioritariamente outros tipos de chamadas; 
- Ativar canais sobressalentes da URA, visando reter o cliente na URA, ou reter por mais tempo do que o disposto na Resolução № $57 / 2004$.

Nos Dias Críticos excepcionais, essas medidas são apenas paliativas. Sempre haverá, nesses dias, um déficit de Posições de Atendimento (PA) e natural queda do Índice de Nível de Serviço Básico (INB). Como conseqüência direta, haverá congestionamento e bloqueio das linhas de entrada da URA e do PABX, pois o tempo de espera aumentará consideravelmente. A mesmo consumidor inconsolável fará diversas tentativas de chamadas, impossibilitando assim que outros consumidores façam contato devido a sinalização de ocupado. Considere-se agora a questão dos custos: nas centrais de teleatendimento em geral, os maiores custos estão nos recursos humanos (KOOLE, 2003), o que demonstra também a inviabilidade de ter à disposição um demasiado excedente de PAs disponíveis de forma constante.

Demonstrado assim que uma Central de Teleatendimento (CTA) convencional tende a não dar vazão à demanda de tráfego telefônico nos Dias Críticos, fica caracterizado um problema de comunicação em tempo real do consumidor de energia elétrica com as concessionárias de distribuição nos dias críticos.

Algumas distribuidoras vêm buscando soluções para esse problema, que é muito amplo, e que exige ação sob diversos focos. Este trabalho propõe-se a descrever as inovadoras experiências das distribuidoras estrangeiras e brasileiras (particularmente de algumas concessionárias do Estado de São Paulo $^{2}$ ) ao providenciar informações em tempo real ao consumidor nos Dias Críticos, o que implica em melhor gerir ou dimensionar tecnologias, administrar informações (internas e externas), bem como conduzir, junto com as autoridades públicas, as situações de emergências que se apresentam repentinamente.

Além do mais, a distribuidora de energia elétrica, ao relacionar-se em tempo real com os seus consumidores, deparara-se com enormes dificuldades. Neste contexto da comunicação em tempo real, algumas dificuldades serão abordadas. Iniciar-se-á pela definição de comunicação em tempo real, e depois pela análise do fenômeno social que é a demanda crescente por informação em tempo real. Em seguida será observada a legislação brasileira, e posteriormente uma abordagem pelos critérios de escolha do veículo de comunicação de massa (ou modernamente chamada mídia). Serão também discutidas as dificuldades de desenvolvimento de uma linguagem adequada de comunicação para com distintos tipos de consumidores, as dificuldades da gestão de emergências e da segurança da informação. Do mesmo modo, serão exploradas novas visões do marketing moderno.

\footnotetext{
${ }^{2}$ Todavia, certamente há experiências inovadoras em distribuidoras fora do Estado de São Paulo, mas devido as restrições de tempo e acesso às informações não foi possível incluí-las neste trabalho.
} 
Outro problema que a concessionária de distribuição enfrenta junto aos seus consumidores é que em breve as centrais de teleatendimento tradicionais, ou call centers, passarão a serem chamados de centros de relacionamento, ou contact centers. Esses nascerão com a missão de unificar as atividades de atendimento ao consumidor em um só sistema muito mais completo. No contact center será possível não só atender uma chamada ou solicitação, mas antecipar problemas, soluções e negócios, conforme indica a INTEL (2004b). A demanda dos consumidores por serviços dessa amplitude de flexibilidade e rapidez será crescente, e inevitável (BLACKIE, LINGIE; BROWN, 1999). Nessa mesma linha, segundo a empresa AVAYA (2006), a tecnologia de informação avança sob a ótica do seu usuário final quando, por exemplo, observa-se que há uma tendência de que em alguns anos cada aparelho de comunicação irá computar, e cada computador irá se comunicar. Uma nova gama de serviços irá utilizar vídeo, áudio, dados e texto, através da combinação de comunicadores portáteis, e-mails, auto-atendimento e serviços sob a Internet. Muito em breve os modernos contact centers deverão ser capazes de praticar:

- Computer Telephony Integration (CTI);

- Acesso multimídia (voz, dados, texto e vídeo);

- Controle avançado das chamadas;

- Auto-atendimento com respostas interativas;

- Ferramentas de análise de dados históricos e de tempo real.

Porém, encontrar essas tecnologias de informação e o mix mais adequado destas tecnologias para cada contact center pode consumir tempo. Este trabalho busca identificar e reunir essas tecnologias, e relacionar a prioridade de implantação de cada uma delas.

Distinto aspecto do problema é que a partir do crescimento exponencial de pessoas que têm acesso a rede mundial Internet no Brasil, a tendência é de aumentar os contatos de consumidores através de e-mail, Chat e e-Collaboration com as empresas (TELETIME, 2006). Hoje em dia, praticamente toda distribuidora possui uma página publicada na Internet visando relacionamento com o seu consumidor, páginas que podem ser aperfeiçoadas. Será observado neste trabalho que as modernas tecnologias de comunicação juntas podem aprimorar a qualidade dos serviços de atendimento nos contact centers das distribuidoras. Serão abordados os critérios da qualidade de serviço de atendimento telefônico segundo a ANEEL (ponderando a sua validade para os Dias Críticos), propondo critérios mais alinhados com a comunicação multimídia e mais focados na diferenciação do consumidor. 
Também serão analisados métodos tradicionais de engenharia de tráfego telefônico para o aprimoramento do dimensionamento das Centrais de Teleatendimento (CTA), métodos esses que poderão ser aplicados para os Dias Críticos.

Este trabalho visa fundamentalmente contribuir com o setor elétrico sugerindo também uma metodologia para previsão da quantidade de Chamadas Oferecidas (COf) pelo consumidor para as Centrais de Teleatendimento (CTA) das distribuidoras na situação de Interrupção de Emergência nos Dias Críticos. Segundo a Resolução № 57/2004 da ANEEL, as Chamadas Oferecidas são as ligações telefônicas, não bloqueadas por restrições advindas da operadora de serviço telefônico, que visam o acesso à Central de Teleatendimento. Essa metodologia proposta surgiu de um estudo de caso real de uma distribuidora, e abrange também cálculos de engenharia de tráfego e uma análise de resultados.

\subsection{JUSTIFICATIVA}

As distribuidoras de energia estão atravessando algumas mudanças em seu negócio, principalmente a partir de modificações no campo regulatório, que permitiu a entrada de competidores, criando o conceito de mercado livre para consumidores. Essas mudanças, aliada à dependência de energia elétrica por parte da sociedade moderna, conduzem à necessidade de reorganização de recursos e novos investimentos para atender uma demanda crescente, sobretudo pela qualidade da energia e qualidade de serviços.

A ANEEL criou o Índice ANEEL de Satisfação do Consumidor (IASC), cujo objetivo principal é avaliar, a partir da percepção dos usuários, o grau de satisfação com as concessionárias distribuidoras de energia elétrica. No IASC de 2005 (ANEEL, 2006) foi divulgado o critério de Qualidade Percebida, com três dimensões. Na dimensão "Informações ao Consumidor", houve um decréscimo significativo em relação a 2004 (1,5\%), movimento este que se repete desde 2003 (Tabela 1). Entretanto, na dimensão "Acesso à Empresa", o resultado global apresentou crescimento de 1,21\%, em relação ao ano anterior, e na dimensão “Confiabilidade nos Serviços", o resultado global brasileiro apresentou crescimento de 3,38\%, em relação ao ano anterior ${ }^{3}$.

\footnotetext{
${ }^{3}$ As respostas do IASC foram obtidas de consumidores através de notas de 1 a 10, variando de Muito pior que o esperado, Pior que o esperado, Como o esperado/ Igual ao esperado, Melhor que o esperado, Muito melhor que o esperado, respectivamente. Existe no IASC também o conceito de Benchmark, que seria a empresa referência para as demais, pois possui o melhor desempenho dentro do mesmo setor produtivo.
} 
Tabela 1: Itens de Informação ao Cliente do IASC $2005^{4}$.

\begin{tabular}{|l|c|c|c|c|c|c|c|}
\hline \multicolumn{1}{|c|}{ Informações ao Cliente } & 2000 & 2001 & 2002 & 2003 & 2004 & 2005 & Var. \\
\hline $\begin{array}{l}\text { Explicação sobre o uso adequado da } \\
\text { energia. }\end{array}$ & 58,99 & 64,25 & 63,95 & 60,85 & 58,65 & 58,25 & $-0,68 \%$ \\
\hline Segurança no valor cobrado. & 57,55 & 61,06 & 60,56 & 58,64 & 55,65 & 56,00 & $0,63 \%$ \\
\hline $\begin{array}{l}\text { Atendimento igualitário a todos os } \\
\text { consumidores. }\end{array}$ & 54,46 & 65,62 & 68,23 & 66,36 & 64,22 & 63,78 & $-0,69 \%$ \\
\hline $\begin{array}{l}\text { Informação/Orientação sobre riscos } \\
\text { associados ao uso da energia. }\end{array}$ & 64,48 & 61,35 & 61,73 & 59,75 & 57,92 & 57,88 & $-0,07 \%$ \\
\hline $\begin{array}{l}\text { Esclarecimentos sobre seus direitos e } \\
\text { deveres. }\end{array}$ & 55,61 & 60,11 & 59,30 & 58,02 & 55,44 & 55,78 & $0,61 \%$ \\
\hline Detalhamento das contas. & 52,82 & 67,65 & 69,04 & 66,56 & 64,45 & 65,55 & $1,71 \%$ \\
\hline
\end{tabular}

Fonte: ANEEL, 2006

O resultado geral do IASC é numerado pelo Índice de Satisfação Global. O Brasil, para 2005, apresentou pequeno acréscimo em relação a 2004: de 58,88 (2004) para 61,38 (2005) pontos (variação positiva de 4,25\%). Mas deve-se comparar estes índices de satisfação com os índices dos países EUA e Hong Kong (ver Gráfico 1). Enquanto o Índice de Satisfação Global brasileiro nos últimos cinco anos está estabilizado na média de 62,4, no EUA este índice em 2005 esteve em 73,00 e em Hong Kong em 72,80.

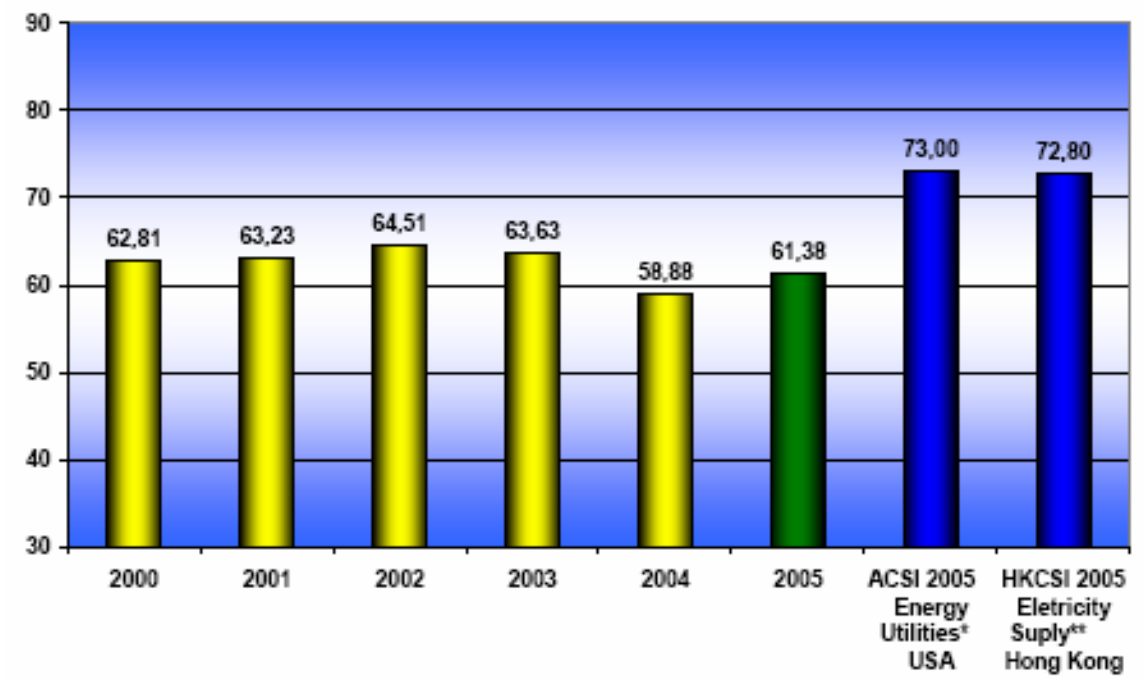

Fonte: ANEEL, 2006

Gráfico 1: Índice ANEEL de Satisfação do Consumidor (IASC) e os Benchmarks Internacionais.

Consta no próprio IASC 2005 que: a) os valores de Benchmark indicam um grande potencial de crescimento e melhoria de desempenho para diversas concessionárias, tanto em relação às distribuidoras de melhor desempenho no Brasil, quanto ao desempenho das distribuidoras dos EUA; b) a maioria dos resultados para cada dimensão e para todos os subitens encontra-se na faixa de "Como Esperado" (com pior resultado para o Norte, Nordeste e Centro-Oeste).

\footnotetext{
${ }^{4} \mathrm{O}$ Benchmark neste indicador alcançou 78,17 pontos.
} 
Portanto, de uma forma geral, a excelência no relacionamento com o consumidor ainda se constitui em um desafio no Brasil, pois ainda está para ser alcançada.

Como particularização desse processo de busca pela qualidade de serviços, há as situações de desligamento em massa, denominadas Dias Críticos. Condições meteorológicas adversas como tempestades, descargas atmosféricas e chuvas de granizo têm o potencial de danificar simultaneamente e seriamente muitos circuitos da rede de distribuição aérea. Esse tipo de dano só será solucionado quando fisicamente uma equipe estiver no local para reparálo, o que acontecerá somente após localizar o defeito. Assim, grandes tempestades podem resultar em um número enorme de consumidores desligados, levando horas ou até alguns dias para total restabelecimento. Enquanto isso, os consumidores preocupados tentam acessar os serviços de atendimento ao consumidor; contudo sem sucesso devido ao congestionamento inevitável das linhas de comunicação. Espera-se, aliás, que devido as evidentes mudanças climáticas no planeta, as fortes tempestades sejam eventos cada vez mais freqüentes.

A boa notícia é que para esses eventos de desligamento em massa há meios e possibilidades de se evoluírem os sistemas de informações atualmente implantados nas distribuidoras (CEGRELL, EKSTEDT e FORSGREN, 2002). E uma das estratégias fundamentais para essa evolução tem sido adotar tecnologias de informação integradas à rede de distribuição elétrica. Entre esses sistemas encontram-se comumente o Supervisory Control And Data Acquisition (SCADA) e o Geographic Information System (GIS). Entretanto há ainda tecnologias em fase inicial de implementação como o Force Field Automation (FFA), o Enterprise Resource Planning (ERP), o Customer Relation Management (CRM), os sistemas de tarifação remota Automatic Meter Reading (AMR), sistemas de Power Line Comunication (PLC), os centros de atendimento multimídia (voz, fax, mensagens de texto) baseados em Computer Telephony Integration (CTI), e os serviços baseados na Web (serviços de Internet). Este trabalho esforça-se em detalhar alguns desses sistemas.

Entende-se este cenário como campo de oportunidades aos meios acadêmicos e fornecedores de tecnologia ao proporem métodos ou soluções aos problemas práticos das distribuidoras de energia. E devido também a grande semelhança entre as utilities - mesmo atuando em mercados diferentes, como eletricidade, gás, água, e outros serviços públicos diversos - as soluções adotadas para as distribuidoras de energia elétrica podem ser extrapoladas para outras empresas e vice-versa.

Desse modo, faz-se necessário o estudo destas tecnologias e processos de comunicação em tempo real, em conjunto com os conceitos de distribuição de energia elétrica. 


\subsection{METODOLOGIA DE ESTUDO}

\subsubsection{Estrutura do Trabalho}

Este trabalho está divido em quatro partes, conforme descrito a seguir.

\subsubsection{Parte 1: Introdução.}

É parte inicial da dissertação, que contém a delimitação da pesquisa: Considerações Iniciais, Justificativas e Metodologia de Estudo. Estão contidos nos Capítulos 1 e 2.

\subsubsection{Parte 2: Revisão da Literatura e Desenvolvimento}

\subsection{Estado da Arte da Comunicação Durante Emergências}

No Capítulo 3 é descrito o estado da arte, o que inclui as experiências nacionais e internacionais no setor da distribuição de energia elétrica.

\subsection{Caracterização dos Problemas}

O problema da comunicação em tempo real com o consumidor em Dias Críticos é um assunto amplo, e deve ter sua análise delimitada através de alguns temas que auxiliam a compreensão do caso. Os Capítulos abaixo citados compreendem cinco dimensões e contextos distintos do problema estudado:

- Capítulo 4: Aspectos Legais, onde são examinadas as exigências regulatórias pertinentes, bem como um breve histórico do arcabouço legal;

- Capítulo 5: Aspectos da Comunicação em Tempo Real, onde é definida comunicação em tempo real, e revista a questão os veículos de comunicação versus tipos de audiências, a mensagem versus linguagem, estratégias de marketing e a resposta às emergências;

- Capítulo 6: Contexto da Tecnologia de Informação, onde são identificadas as mais avançadas tecnologias de comunicação de massa, e quais serviços de atendimento ao consumidor que estas possibilitam;

- Capítulo 7: Contexto da Qualidade de Serviços, onde são transcritas as métricas de qualidade definidas pela ANEEL para os serviços de atendimento telefônico, apontado critérios complementares, além de identificar outros critérios de qualidade para as redes de comunicação multimídia das concessionárias; 
- Capítulo 8: Contexto da Engenharia de Tráfego Telefônico, onde são revistos a Teoria das Filas e as recomendações internacionais neste campo, além do significado teórico de nível de serviço, de tempos máximos de espera e porcentagem aceitável de abandono e de bloqueio.

\subsubsection{Parte 3: Proposta de Método}

Entre os objetivos desta pesquisa está o de propor uma metodologia para previsão da quantidade de chamadas e ou contatos do consumidor para com a concessionária de energia elétrica nos Dias Críticos, procurando abordar e caracterizar todas as variáveis dessa problemática. Esta proposta é apresentada no Capítulo 9. No Capítulo 10 está uma aplicação do método proposto. O Capítulo 11 contém a discussão dos resultados do método aplicado.

\subsubsection{Parte 4: Considerações Finais}

No Capítulo 12 estão contidas recomendações para as distribuidoras visando solucionar o problema apontado, sugestões de novas pesquisas que complementariam este trabalho, e também contém as conclusões correspondentes aos objetivos previamente definidos.

\subsubsection{Procedimento de Coleta de Dados}

Algumas distribuidoras de energia elétrica do Estado de São Paulo foram consultadas no processo de elaboração deste trabalho. Esses dados foram importantes para validar os resultados da pesquisa. Os dados coletados não representam a totalidade das empresas nacionais, mas permitem delinear uma tendência e uma linha de pensamento.

\subsubsection{Terminologias e Conceitos}

Este trabalho considera que o leitor está familiarizado com a maioria das terminologias e conceitos utilizados. Caso contrário sugere-se a consulta de:

- Tecnologia da Informação: Walter (1998), Alencar (1998), INTEL (2003), Jeszensky (2004);

- Teoria das Filas: Cox (1971);

- Engenharia de Tráfego Telefônico: Bear (1976), Teletraffic Engineering Handbook (2005) da International Telecomunication Union (ITU);

- Centros de Atendimento Telefônicos: Koole (2003). 


\section{O ESTADO DA ARTE DA COMUNICAÇÃO DURANTE EMERGÊNCIAS}

\subsection{DISPONIBILIZAÇÃO DE INFORMAÇÕES EM TEMPO REAL}

Pesquisas mostram que a disponibilização de acesso de informações em tempo real aos consumidores de energia elétrica, no mundo e no Brasil, durante os eventos de interrupção de emergências de grande abrangência, ainda apresenta espaço para aprimoramento. As empresas distribuidoras têm focado mais no processo de restauração, e menos no da comunicação.

Nos EUA, ocorreram no final dos anos 1990 certos movimentos do setor de mídia especializada e de algumas poucas distribuidoras no sentido de ressaltar a questão, segundo indica Lavesque (2000). Audiências públicas sobre o tema foram realizadas em Nova Iorque pelo New York Public Service Commision em Julho de 2000, mas nada de concreto foi determinado. A mesma linha pode ser observada em outros relatórios do governo.

Já em 2001, uma lei que exigiria que as utilities de energia elétrica informassem os grandes consumidores sobre interrupções prolongadas (mais de 4 minutos) foi proposta pelo senador norte-americano John Campbell. A proposta foi chamada de ABX1 52, conforme indicam documentos do California State Senate (2006), e teve o suporte do setor de manufaturas e de tecnologias do estado da Califórnia. Contudo, somente sete senadores votaram a favor, sendo necessários no mínimo vinte e um votos para aprovação. Essa proposta foi decorrente da recente crise energética na Califórnia, quando ocorreram diversos desligamentos devido à crise (ALLBUSINESS.COM, 2006).

Apesar disso, em 2005 certos Estados norte-americanos estavam bem preparados 5 . Durante e após a passagem do furacão Katrina, a distribuidora Florida Power\&Light (FPL) manteve on-line e atualizado seu website, onde era possível obter informações sobre a estimativa de tempo de restauração em uma unidade de consumo individual.

As Figuras 1, 2 e 3 são retratos do website da FPL. Acessando <http://www.fpl.com/residential/customer_service.shtml>, basta entrar com certos dados, como o número da conta de energia, para obter a informação.

\footnotetext{
${ }^{5}$ Vide também item 5.5 deste trabalho.
} 
Esse método da FPL é adequado para aqueles consumidores que mantêm planos de contingência de energia elétrica, como é comum na Flórida, envolvendo principalmente a instalação de pequenos geradores a diesel, que podem ser compartilhados inclusive entre os vizinhos. Outro método de contingência são as baterias e no’breaks, amplamente utilizadas na informática. $\mathrm{O}$ acesso à Internet também deve ser contingenciado, e para isso a comunicação sem fio, muito aplicada nos EUA, é uma saída.

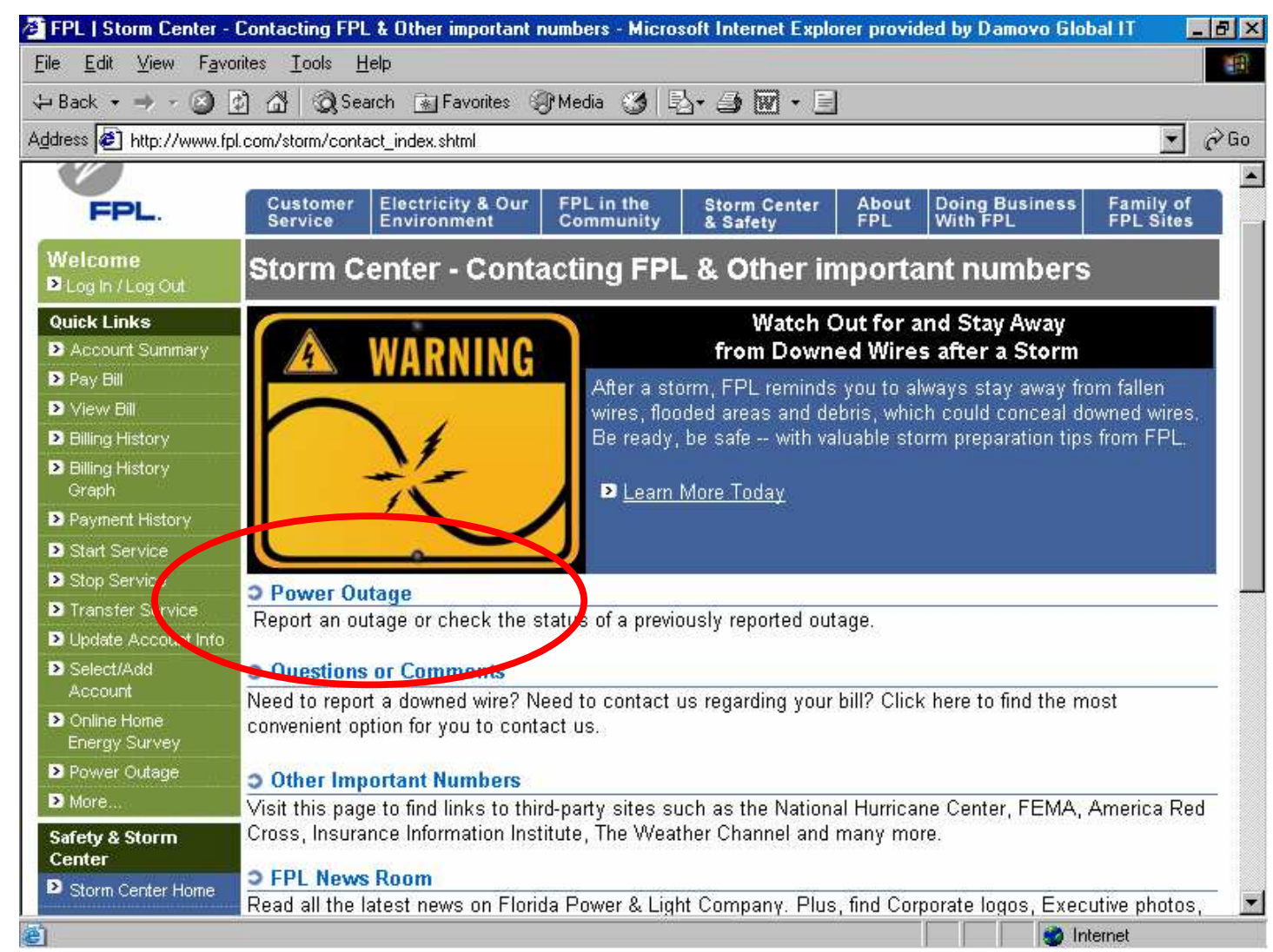

Fonte: Florida Power \& Light, 2005

Figura 1: Reporte de falta de energia elétrica na FPL via vebsite

Em destaque o link para conferir a situação do fornecimento de energia de uma unidade consumidora. 


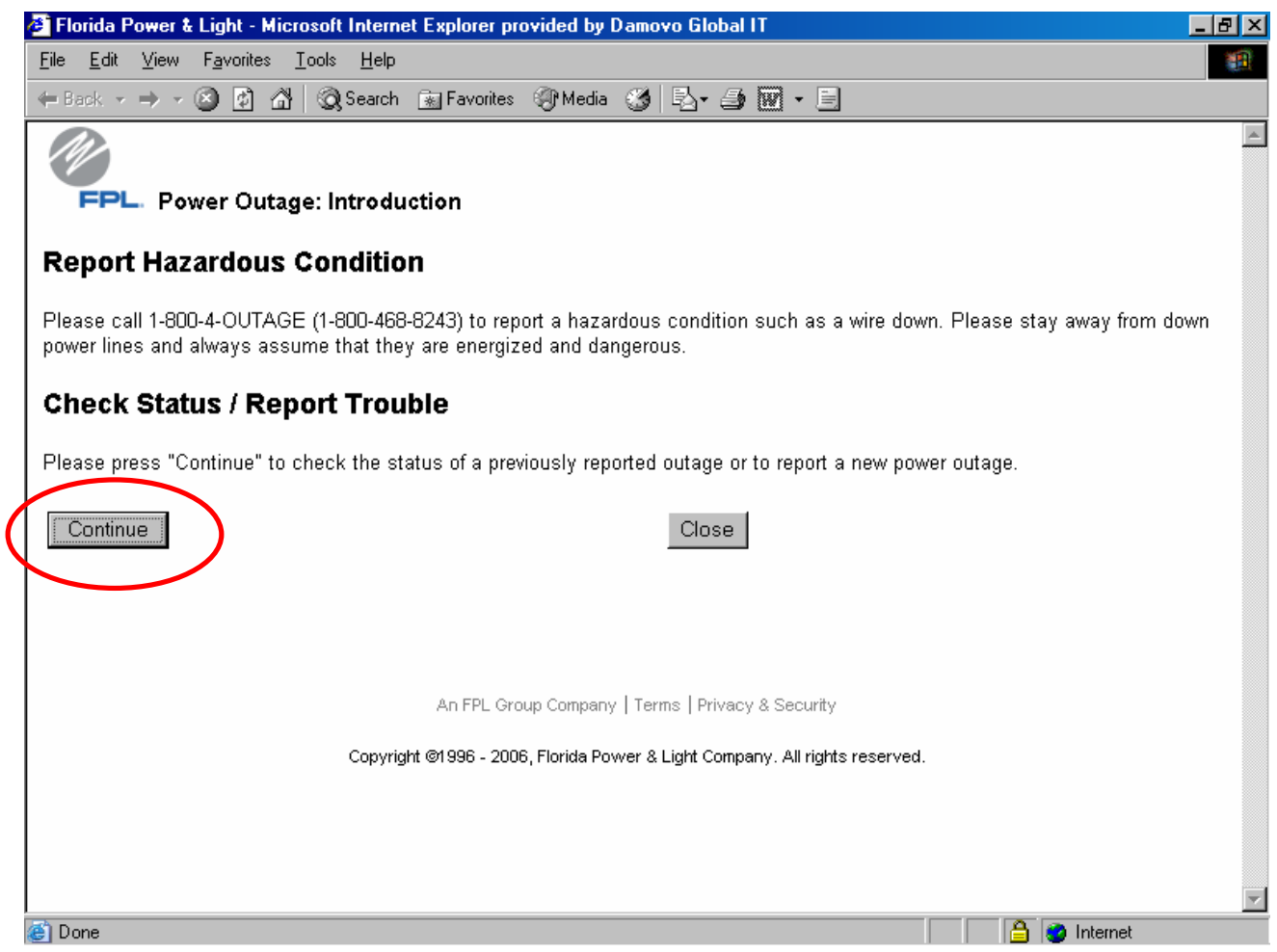

Fonte: Florida Power \& Light, 2005

Figura 2: Tela de Script HTML da FPL, logo depois de acessado o link da figura anterior.

Em destaque, botão para continuar processo. Observe que para reportar uma interrupção, permanece o serviço telefônico como canal preferencial.

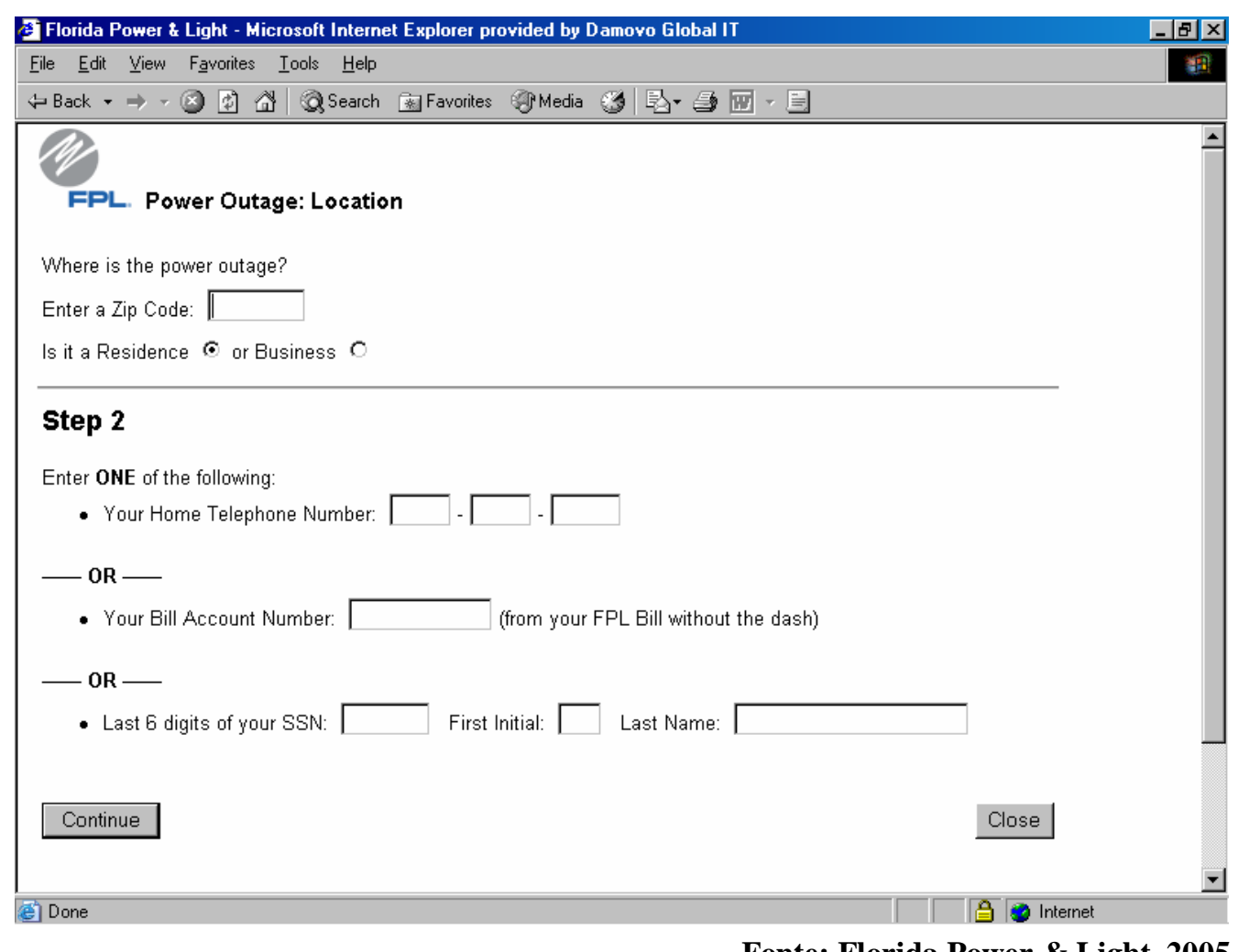

Figura 3: Script seguinte ao da figura anterior.

O consumidor identifica sua unidade consumidora, e dessa forma obtém estimativa de tempo de reparo de seu circuito alimentador. 
O Office for the Regulation of Electricity \& Gas (OFREG), órgão regulador britânico, vem recomendando já há alguns anos (OFREG, 2001) que as concessionárias locais adotem, para com os consumidores, um sistema de comunicação mais efetivo nas situações de desligamento em massa. Entre as principais recomendações pode-se citar:

1) Detectar com agilidade os pontos de falha nos circuitos;

2) Tratar as informações dos consumidores para melhor localizar os defeitos, agilizando a solução dos problemas;

3) Implantar sistemas de mensagens automatizadas para vencer a grande demanda de ligações, e que as mensagens estejam sempre atualizadas;

4) Prover maneiras de avisar os consumidores sobre o tempo de restabelecimento de seus circuitos.

As recomendações da OFREG expandem-se para os processos de gestão de incidentes e emergências na rede de distribuição, exigindo também remodelação tecnológica nessa área e nos procedimentos da operação de rede.

Modificações na Central de Teleatendimento (CTA) da Northern Ireland Electricity (NIE) foram executadas após o calamitoso dia de 26 de dezembro de 1998, quando 680.000 consumidores ficaram nas escuras por até alguns dias devido a uma tempestade de neve na Irlanda do Norte. Muitos dos consumidores estavam conectados através de circuitos primários que em torno de um dia foram restaurados, mas houve dificuldade de identificar desligamentos em circuitos secundários, o que acarretou mais atrasos no restauro. A NIE não conseguia se comunicar com seus consumidores para localizar as faltas, e teve prejuízos da ordem de US\$14,7 milhões somente com indenizações para 80 mil consumidores. Desde então a NIE, em linha com as recomendações da OFREG, permite que seus consumidores reportem falhas nos circuitos através de um formulário na Web, conforme indicado em $<$ http://www.nie.co.uk/contactus/index.htm> e na Figura 4. 


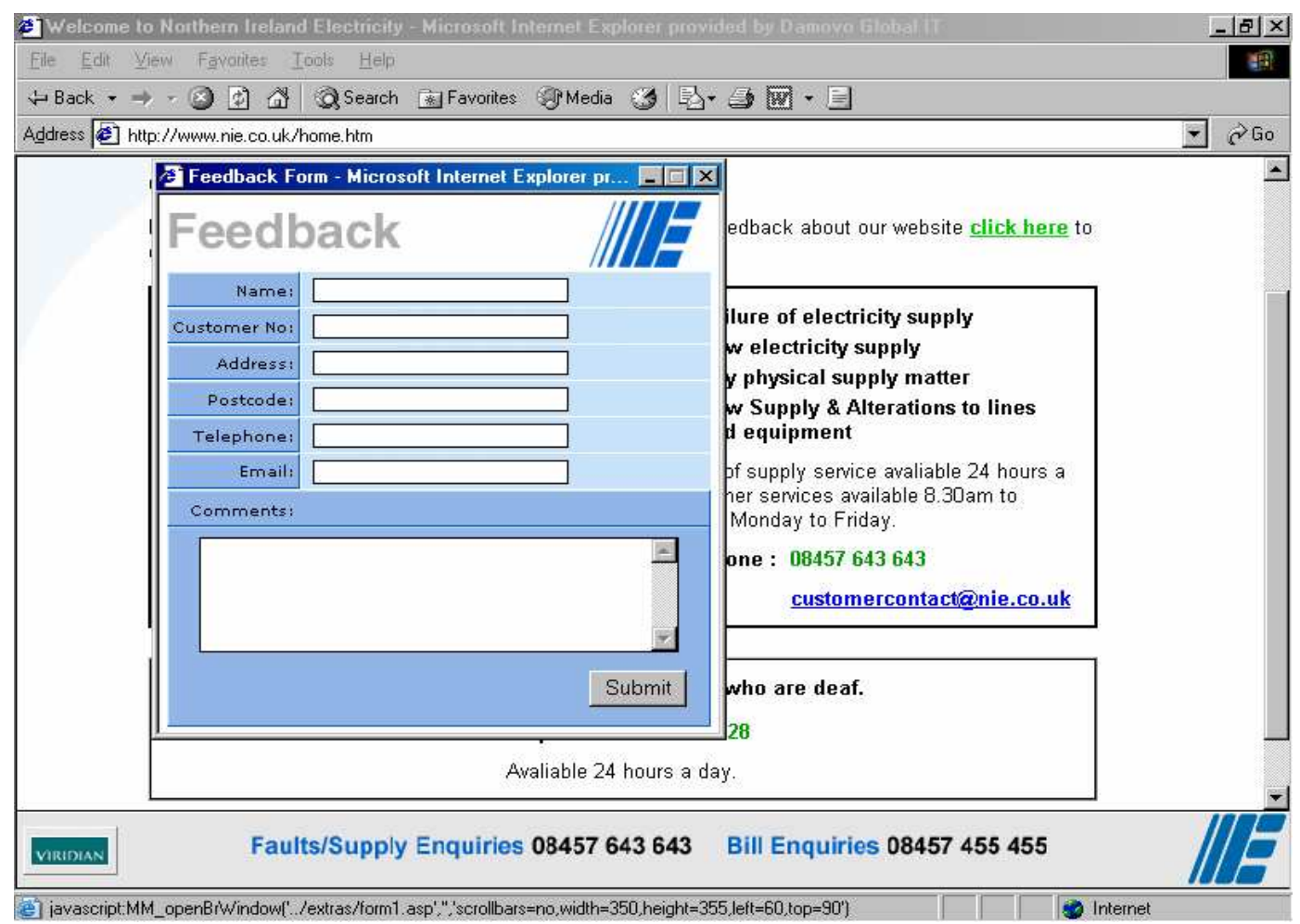

Fonte: NIE, 2006

Figura 4: Formulário na Web da NIE para submissão de reclamações de falta de energia.

A NIE também implantou serviços avançados de auto-atendimento via telefone, divulgando números telefônicos diferenciados para contato a respeito de reporte de falta de energia e emergências (suportando até 200.000 ligações por hora), e também permite agora contato via e-mail. A NIE possui ainda um registro de consumidores com necessidades especiais (médicas, etc.), para os quais é garantida instalação gratuita de um gerador com motor a combustão para o caso de falhas elétricas.

O segundo exemplo europeu é o da Scotish Power. Esta distribuidora escocesa permite acesso a informações especiais em seu website (ver Figura 5), de forma que cada consumidor pode obter um usuário (e-mail address) e senha (password) para este acesso (login). A partir do acesso on-line, pode-se comprar energia (pré-paga) ou ver o próprio gasto (através de tecnologia de AMR). O mesmo pode ser feito por um serviço de atendimento automático por telefone, via Unidade de Resposta Audível (URA). Assim como a NIE, a Scottish Power também divulga e-mails de contato, e números telefônicos diferenciados para contato a respeito de falta de energia. 


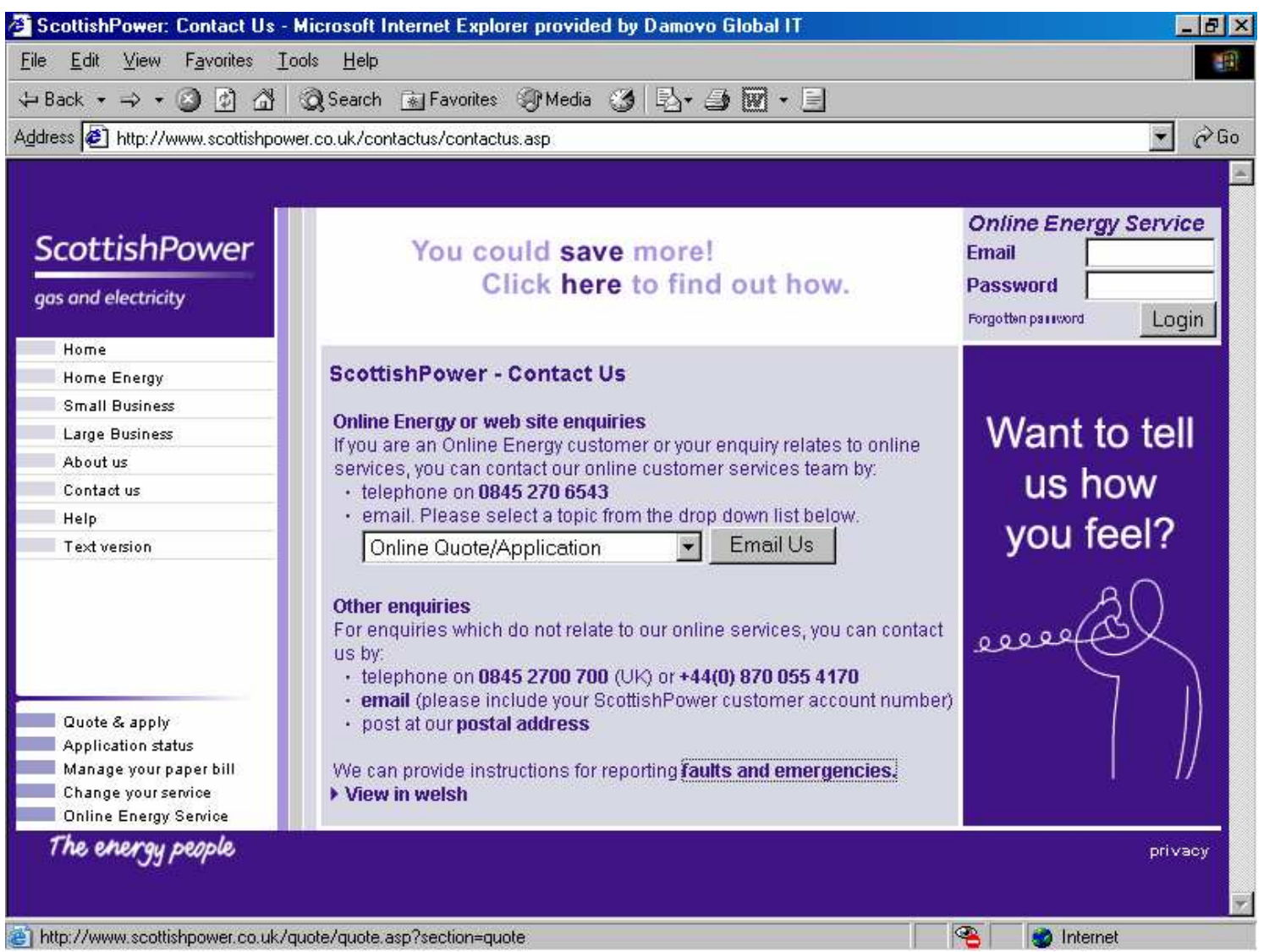

Fonte: Scotish Power, 2006

Figura 5: Web Services da Scottish Power.

O que parece ser comum entre os casos internacionais citados é a preocupação quanto à conscientização prévia do consumidor, o que visa evitar ligações nas centrais de teleatendimento e até mesmo desgaste à imagem pública. Um exemplo dessa atitude é o da ConEdison (2005), distribuidora da região norte americana de Nova Iorque. A Figura 6 é ilustrativa de sua campanha de conscientização via Internet.

Mas segundo Levesque (2000), o provável motivador das distribuidoras nos EUA para aprimorar sua comunicação com o consumidor está no medo de penalidades regulatórias e judiciais, e não o desejo da completa satisfação do consumidor. O fato é que as distribuidoras dos EUA não negam que a expectativa dos consumidores por informações tem crescido, e por isso Lavesque sugere realização de pesquisas entre os consumidores sobre o assunto.

Quanto as distribuidoras brasileiras, obteve-se ciência que a AES Eletropaulo, distribuidora da região da Grande São Paulo, já possui estudos sobre formas alternativas de atingir o consumidor nestes casos de desligamento em massa ${ }^{6}$.

\footnotetext{
${ }^{6}$ Atualmente muito de seu website <http://www.eletropaulo.com.b>r já automatiza os serviços comerciais em dias de situação normal.
} 
Uma dessas ações foi divulgada pela AES Eletropaulo no XVI Seminário Nacional de Distribuição de Energia Elétrica (SENDI), um projeto de pesquisa e desenvolvimento (P\&D), denominado Sistema Ativo de Aviso de Interrupções no Fornecimento de Energia Elétrica (DAMAS, MIRANCOS e ARIEIRO, 2004). Atualmente parte desse sistema já está funcional.

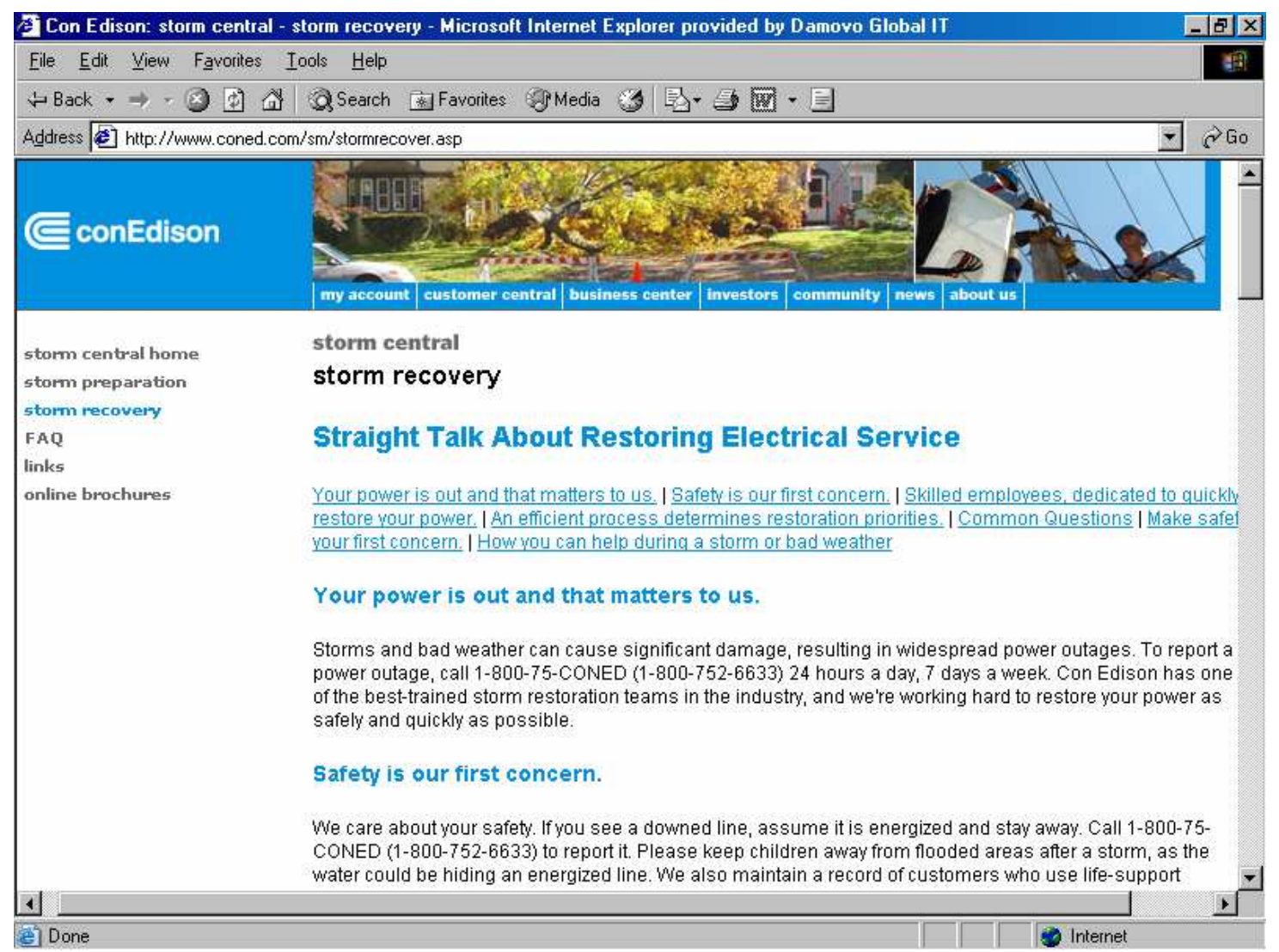

Fonte: ConEdison, 2006

Figura 6: Conscientização via Internet de consumidores da ConEdison, referente a dias de tempestade

A AES Eletropaulo possui ainda uma Unidade de Resposta Audível (URA) de 270 canais de acesso simultâneo, canais esses ativados conforme a necessidade. Quanto ao atendimento humano, nos meses mais críticos do ano (tipicamente na estação chuvosa), é programado um número maior de posições de atendimento de plantão. Eventualmente, para os dias mais críticos, há estratégias de transbordo de chamadas para um centro de atendimento de uma prestadora de serviços terceirizada ${ }^{7}$. Esse tipo de estratégia de transbordo de chamadas aumenta virtualmente a capacidade de atendimento da empresa, sem incremento permanente de despesas.

\footnotetext{
7 A terceirização é hoje uma tendência mundial com benefícios comprovados. No caso dos centros de atendimento e da tecnologia de informação, a terceirização vem evoluindo e o seu foco não está mais limitado na redução de custos. Cada vez mais as empresas terceirizam processos de negócios, buscando melhorar o nível de serviço oferecido a seus clientes, e garantir escalabilidade e flexibilidade ao seu negócio [MOREIRA, 2006]. A previsão é que o mercado de terceirização de call center cresça anualmente 20\% até 2010 [FERREIRA, 2006].
} 
Ao mesmo tempo, recentemente a Eletropaulo também aprimorou seus serviços de ouvidoria, além de divulgar número telefônico diferenciado para reclamações de falta de energia. Também tem adotado uma política pró-ativa de comunicar-se com o consumidor nos Dias Críticos, através de entrevistas concedidas em canais de rádio local (AM/FM) de grande audiência.

A CPFL, maior distribuidora do interior do Estado de São Paulo, também possui ações específicas e inovadoras. A CPFL possui uma URA cuja função é atender $100 \%$ das chamadas dirigidas à CTA, incluindo as interrupções de emergência, sendo capaz de identificar os consumidores. A identificação se dá pela validação do número da linha telefônica do consumidor, que foi previamente cadastrado ${ }^{8}$. Depois, é automaticamente consultado sobre a sua situação de fornecimento em um sistema denominado TRIAGEM, sendo analisado em tempo real a situação de diversos circuitos primários e secundários. $\mathrm{O}$ banco de dados do TRIAGEM é alimentado pelo SCADA (que monitora on-line alguns pontos críticos da rede elétrica), mas também pelo pessoal de campo, ou mesmo por consumidor que tenha reportado à CTA interrupções. Assim sendo, a CPFL é capaz de fazer interpolações, e predizer quais consumidores estão interrompidos.

Caso o consumidor tenha sido identificado como desligado, este é transferido dentro da URA para uma rotina de mensagem que verbaliza que a CPFL já conhece a situação e qual é o tempo de restauro previsto. O tempo de restauro é atualizado com certa frequiência pelo pessoal de campo, de modo a manter os consumidores up-to-dates. No final da mensagem, o cliente tem a opção de desligar a chamada ou ser transferido para o atendimento pessoal para obter maiores informações. Mas a experiência tem mostrado que este tipo de implementação de URA filtra muitas ligações, e consegue reduzir a necessidade de atendimento pessoal. Caso o cliente identificado na URA for do Grupo A de consumidores, a URA transfere para um atendimento pessoal específico e mais especializado.

\subsection{A GESTÃO DAS INFORMAÇÕES NAS DISTRIBUIDORAS}

Prevalecer em um cenário de grande demanda de chamadas e prover meios de informar consumidores sobre o tempo de restauração de seus circuitos interrompidos, garantindo informações atualizadas, remete a:

- Profundas questões sobre integração de sistemas;

- Gerenciamento em tempo real de informações.

\footnotetext{
${ }^{8}$ Vide <http://www.cpfl.com.br/new/brasil/saiba_mais.asp>.
} 
Estes desafios demandam ajustes e atualizações tecnológicas por parte das concessionárias, principalmente em seus centros de controle e gerenciamento de informações. Internacionalmente, tais temas têm sido resolvidos com o apoio e a inovação de técnicas de Inteligência Artificial, conforme pesquisas e relatos de Balakrishnan e Pahwa (1990), Kirschen e Volkmann (1991), Kearney (1998), e Sridharan e Schulz (2001).

Estudos de Lubkeman e Julian (2001) indicam que o gerenciamento de informações para eventos de desligamentos em massa devido a tempestades difere dos desligamentos convencionais principalmente na escala de danos físicos à rede, requerendo um grande número de equipes de reparo para serviços de restauro até a ponta do consumidor. Muitas vezes chega-se ao ponto de sub-contratar equipes terceiras para atender a demanda repentina. Nos desligamentos convencionais, não se opera tradicionalmente em modo pró-ativo. $\mathrm{Na}$ situação de desligamento em dias de tempestades, já ocorre essa necessidade de ações próativas, situação que exige ampla disponibilidade de informações em tempo real e apoio de sistemas inteligentes.

Todavia, há muitas distribuidoras utilizando sistemas dimensionados e desenhados para atender situações de desligamentos convencionais para atender situações de desligamento em massa em dias de tempestades; quando não muito, utilizam ferramentas que nasceram para atender demandas convencionais, mas que foram customizadas para a situação de desligamento em massa.

Usando um sistema de gerenciamento de informações adequado, o operador deste sistema pode rastrear os desligamentos, consumidores afetados, locais onde estão as equipes, e coordenar as demais atividades e esforços para o processo de reparo, tornando-as mais eficientes. Informações do sistema de gerenciamento são providas por:

- Comunicação direta com os consumidores;

- Relatórios de equipes de campo;

- Sistemas de $A M R$;

- Sistemas SCADA;

- Agências de emergência ou de notícias;

- Previsões de aplicações de inteligência artificial visando localização de defeitos de rede (exemplo: redes neurais).

Baseado nessas informações, o sistema de gerenciamento tem como dado de saída principal a estimativa do tempo de restauro de cada consumidor afetado. Dessa forma, a distribuidora estará pronta, ao menos nesse sentido, para responder às requisições dos 
consumidores a respeito de suas ações e atitudes quanto ao desligamento, e também sobre o tempo de restauro estimado.

É válido ainda citar que há também muitas aplicações de suporte à gestão de informações que fazem parte de uma solução completa de uma Central de Teleatendimento. As principais são os sistemas de Front Office para atendentes e supervisores. Essas são aplicações que permitem visualizar dados históricos dos contatos de clientes, atualizar os dados, automatizar o fluxo de trabalho dos atendentes, entre outras funções. Sistemas de Gestão de Relacionamento com Clientes tais como o produto SAP CRM da empresa SAP incluem módulos de Front Office. Citam-se ainda sistemas de Back Office para gerenciar funções de retaguarda da Central de Teleatendimento: logística, entrada e acompanhamento de solicitações, e suporte técnico aos atendentes. Exemplos internacionais na implantação desses sistemas de suporte podem ser encontrados na Northern Ireland Eletricity (NIE), distribuidora da Irlanda do Norte (MURPHY, BALLENTINE e ROONEY, 2001) e na ScotishPower, distribuidora da Escócia (MACFARLANE, 1998).

No Brasil, a própria AES Eletropaulo, principalmente para a estação chuvosa, atualmente conta com um sistema de gerenciamento de turmas e a instalação de equipamentos de Global Positioning System (GPS) - sistema de navegação baseado na recepção de sinais via satélite - na frota de serviço, conjuntamente com softwares ${ }^{9}$ meteorológicos em sua Central de Operações. Quando o cliente da AES Eletropaulo liga para a Central de Teleatendimento reclamando da falta de energia, uma ordem de serviço é gerada e encaminhada para os Centros de Distribuição de Serviços de todas as unidades regionais. Os operadores transmitem por rádio a ordem de serviço para as equipes na rua, conforme a natureza do pedido. $\mathrm{O}$ gerenciador de turmas permite aos funcionários dos Centros de Despachos de Serviços visualizarem no mapa eletrônico a localização em tempo real da equipe mais próxima para atender a ocorrência. O GPS do mesmo modo pode traçar automaticamente o trajeto ideal (com mão e contramão) para que a equipe chegue mais rapidamente ao local de desligamento (ELETROPAULO, 2005).

$\mathrm{Na}$ CPFL, cerca de $40 \%$ da operação da rede elétrica já conta com o apoio do Geographic Information System (GIS), e esforços vem sendo empreendidos no sentido de completar esta porcentagem.

\footnotetext{
${ }^{9}$ Esses softwares são capazes de prever a queda de chuvas, velocidade de ventos e descargas elétricas que podem provocar o desligamento de circuitos na região metropolitana da capital de São Paulo.
} 


\subsection{A GESTÃO DA TECNOLOGIA DE INFORMAÇÃO}

Como melhor será demonstrado em Capítulos posteriores deste trabalho, a Tecnologia da Informação (TI) é peça chave para resolver o problema de comunicação em tempo real com o consumidor. Então uma melhor gestão neste campo das empresas implica em um produto ou um serviço de melhor qualidade para os seus clientes.

Uma tendência internacional na área de gestão de Tecnologia de Informação (incluindo como as empresas devem se relacionar com o seu público externo), e que afeta principalmente as empresas norte americanas e as suas subsidiárias espalhadas pelo mundo, é a implementação do The Sarbanes-Oxley Act of 2002, também conhecido como The Public Company Accounting Reform and Investor Protection Act of 2002, mais comumente como SOX.

O SOX é uma lei federal dos EUA preparada em resposta aos escândalos da Enron e WorldCom. Esses escândalos resultaram no declínio da confiança pública nas práticas tradicionais de gestão empresarial, principalmente nas questões relativas às informações divulgadas à população em geral. Essa legislação foi estabelecida e padronizada para todas as grandes corporações norte-americanas, responsabilizando criminalmente a diretoria executiva das empresas envolvidas.

Os principais itens dessa lei versam sobre a independência das auditorias e governança corporativa principalmente dos recursos de tecnologia de informação. Cabe, de acordo com o SOX, ao Chief Information Officer (CIO) da empresa analisar os riscos, implantar itens de controle e de monitoração, além de gerenciar atividades nos sistemas de comunicação e informação da empresa. Segundo a revista Computer World (2006), muitos investimentos estão sendo feitos pelas empresas norte-americanas e suas afiliadas para adaptação de suas instalações à nova lei, e a maioria (67\%) já adotou sistemas diferenciados para essa adaptação.

A adequação ao The Sarbanes-Oxley Act of 2002 tem impulsionado uma outra tendência internacional na gestão de Tecnologia de Informação, que é o Control Objetives for Information Related Technology (COBIT), basicamente um guia de melhores práticas e governança em TI. Ao seguir o modelo do COBIT, a empresa fortalece sua capacidade de observação e controle do ambiente de TI. O COBIT também aponta o que deve ser melhorado, embora não diga como fazer. Há framework diversos, ou seja, metodologias desenvolvidas para implementação do COBIT, como o Itil, BS7799, CMMi, e Balanced Scorecard. Quem decide qual framework usar é a própria empresa. 
O COBIT foi desenvolvido inicialmente pelo instituto norte-americano IT Governance Institute (ITGI). Atualmente, na versão 4.0 (de dezembro de 2005), é composto de 34 processos de TI, como a definição de plano estratégico, gerenciamento de projetos, avaliação de riscos, gerenciamento de mudanças, entre outros. Seu principal benefício é trazer informações organizacionais integradas em uma mesma estrutura: planejamento e organização; aquisição e implementação; entrega e suporte; e por fim, monitoramento e evolução [TERZIAN, 2006].

Cita-se ainda a ISO/IEC 27001, denominada Information Technology - Information Security Management Systems Requirements, norma internacional de gestão de segurança de informação, publicada pela International Organization for Standardization (ISO) e pela International Electrotechnical Commission (IEC) em outubro de 2005. A ISO 27001 é aplicada em conjunto com a norma ISO 17799 (Código de Boas Práticas da Gestão de Segurança de Informação), e juntas as duas normas são atualmente as principais referências para as empresas que buscam tratar a questão da segurança de informação de forma eficiente.

Ainda são poucas empresas certificadas na ISO 27001, certificação que segue o mesmo esquema das já tradicionais ISO 9001 e ISO 14001. Não há nenhuma distribuidora de energia brasileira certificada ${ }^{10}$. Entretanto, no Brasil ${ }^{11}$ há grandes distribuidoras como a Eletropaulo, CPFL e a COPEL realizando movimentos para adaptação ao The Sarbanes-Oxley Act of 2002.

\subsection{OS PLANOS DE RESPOSTA A EMERGÊNCIAS ENERGÉTICAS}

De acordo com Jefkins (1994), seguindo uma investigação sobre 1500 corporações norte-americanas, apenas $53 \%$ dessas empresas tinham um plano que as habilitaria a se comunicarem rapidamente com seu público de consumidores e com a imprensa em casos de emergências. A maior parte destes planos foi desenvolvida depois de já ter ocorrido uma crise. Ao invés disso, a maioria das organizações procuram estar preparadas para reduzir as probabilidades de virem a se defrontar com grandes emergências.

\footnotetext{
${ }^{10}$ A relação das empresas com certificação ISO 27001 pode ser acessada em <http://iso17779.safemode.org/index.php?page=ISO_27001_Certifications>

${ }^{11}$ Muitas de nossas distribuidoras de energia são controladas por empresas cuja sede ou matriz é norteamericana.
} 
Nem sempre isso é totalmente viável, principalmente quando se lida com as forças da natureza, como indica o caso do Estado da Flórida (nos EUA), que é exemplo do uso de inovadoras práticas de planejamento, de comunicação com seu público e de trabalho conjunto de autoridades locais. Durante 2004, na Flórida, quatro grandes furacões causaram muita destruição. Particularmente o furacão Francys interrompeu um total de 4.270.000 consumidores, com tempo de religamento de até 15 dias. A restauração foi coordenada pelas distribuidoras, mas com total colaboração das autoridades locais e de um centro regional de resposta à emergência. A experiência de 2004 foi descrita em relatório denominado Florida State's Energy Emergency Response to the 2004 Hurricanes, e divulgada pelo National Association of State of Energy (2005). Os eventos de 2004 foram experiência para os mais graves de 2005 (como o furacão Katrina).

Desde então as autoridades da Flórida têm planejado a salvaguarda energética, mirando na excelência. As autoridades municipais, estaduais, regulatórias e as organizações privadas do setor energético desenvolveram guias para as emergências. Existem planos e acordos mútuos, incluindo procedimentos operacionais e reservas de fontes energéticas, visando a restauração de circuitos em curto prazo, além da informação e a segurança do povo. E em Fevereiro de 2005 o United States Department of Energy regulamentou diversas normas obrigando que as distribuidoras tomassem medidas de precaução aos eventos desse tipo num prazo de até 10 meses. A questão da necessidade de treinamento para simular a capacidade das organizações nessas ocasiões também foi levada em consideração.

Abaixo os resultados dessas ações de planejamento de resposta a emergências energéticas do estado da Flórida em 2005:

- Em 2005, o Estado da Flórida, e de mesmo modo o Estado de Lousiana, sofreram a pior temporada de furações em décadas (muito superior aos eventos de 2004), devastando toda a rede de distribuição aérea. As autoridades da Flórida, ao lado da distribuidora Florida Power \& Ligth (FPL), já haviam mapeado todos os riscos, e haviam tomado medidas preventivas, organizando-se, inclusive alertando os moradores locais sobre procedimentos de segurança. Foram montados planos de contingência, de monitoração, de comunicação com a comunidade, de reparo, etc., ao todo envolvendo 12 comitês interdependentes (FLORIDA POWER \& LIGHT, 2005b). 
- Em 26 de agosto de 2005, dia posterior à passagem do furacão Katrina, foi divulgado o primeiro relatório de danos do USA Departament of Energy, através do OFFICE OF ELECTRICITY DELIVERY AND ENERGY RELIABILITY (2005a) que relatava, às 10:30 hs da manhã, aproximadamente 1.221.500 consumidores sem eletricidade. Nesse relatório nenhuma expectativa de tempo de restauração fora dada. O total de consumidores da Flórida é de 9.081.958, ou seja, 13\% haviam sofrido interrupção, a maioria dentro da região da FPL. A FPL mobilizava naquele instante mais de 3.000 funcionários, além de mais de 4.000 extras (FLORIDA POWER \& LIGHT, 2005a).

- No dia 29 de agosto de 2005, às 16:00 hs, o OFFICE OF ELECTRICITY DELIVERY AND ENERGY RELIABILITY (2005b) tinha informado, em seu relatório número 8 sobre os danos, que o estado de Lousiana tinha naquele momento, $42 \%$ dos consumidores desligados, aproximadamente 905.000 consumidores. Entre as distribuidoras mais afetadas estava a Entergy Louisiana, que teve 63\% dos consumidores desligados, ou seja, 409.400 aproximadamente.

- Neste mesmo dia a FPL informava que apenas 264.200 consumidores estavam desligados devido ao Katrina. A FPL antecipava que 90\% destes consumidores estariam religados até o dia 30 de agosto ao final da noite.

No Brasil, e particularmente no Estado de São Paulo, é possível contar com a DEFESA CIVIL (2006), um órgão ligado ao Gabinete do Governador. Como órgão estadual tem a missão de gerenciar as emergências locais, cabendo também coordenar e supervisionar as ações de defesa civil, manter e atualizar informações específicas, elaborar e implantar projetos dessa natureza.

A Defesa Civil do Estado de São Paulo desenvolve os chamados Planos Preventivos de Defesa Civil (PPDC). O PPDC envolve um trabalho de articulação de recursos técnicos e humanos, com preparo, estruturação e treinamento das equipes municipais e da comunidade, monitoramento meteorológico e pluviométrico, emissão de boletins Meteorológicos e de Alertas que são repassados para as Prefeituras, Corpo de Bombeiros, Polícia Militar, Regionais de Defesa Civil e as Coordenadorias Municipais de Defesa Civil. O objetivo do PPDC é aperfeiçoar os recursos existentes e antecipar situações de risco, articulando o trabalho com diversas agências e departamentos públicos e privados. 
Um desses PPDC é a Operação Verão, período do ano que na região sudeste é de chuvas intensas. A ativação do plano acontece de 01 de dezembro a 31 de março de cada ano. Na Operação Verão da Defesa Civil são também reforçadas ações preventivas, de preparação, de resposta e recuperativas, visando prevenir ou minimizar as conseqüências típicas geradas pelas chuvas, haja vista que as conseqüências mais comuns do período de verão são: inundações, alagamentos, escorregamentos de terra (deslizamentos), vítimas de raios, vítimas de vendavais e granizo, e prejuízos aos serviços essenciais (energia elétrica, água, saneamento e saúde). Os órgãos envolvidos na Operação Verão são:

- Coordenação geral: Coordenadoria Estadual de Defesa Civil (CEDEC), por meio de suas Coordenadorias Regionais de Defesa Civil (REDEC);

- Municípios: Coordenadorias Municipais de Defesa Civil (COMDEC) e Secretarias municipais;

- Instituto de Pesquisas Tecnológicas (IPT);

- Instituto Geológico (IG);

- Departamento de Águas e Energia Elétrica (DAEE);

- Órgãos e Institutos de Meteorologia, que concentram suas informações no Centro de Gerenciamento de Emergências (CGE) ${ }^{12}$;

- Polícia Militar do Estado de São Paulo;

- Corpo de Bombeiros da Polícia Militar;

- Lideranças comunitárias (principalmente as residentes nas áreas de risco);

- Prestadores de serviços públicos essenciais (energia elétrica, água, saneamento e saúde).

Ainda no Estado de São Paulo, existe o Sistema de Alerta a Inundações de São Paulo $\left(\right.$ SAISP) ${ }^{13}$, operado pela Fundação Centro Tecnológico de Hidráulica (FCTH), que gera a cada cinco minutos boletins sobre as chuvas e suas conseqüências na cidade de São Paulo. O monitoramento hidrológico do SAISP é feito pela Rede Telemétrica de Hidrologia do Departamento de Águas e Energia Elétrica do Estado de São Paulo (DAEE) e pelo Radar Meteorológico de São Paulo, de propriedade do DAEE e adquirido em convênio com a Fundação de Amparo a Pesquisa do Estado de São Paulo (FAPESP). As concessionárias de energia elétrica podem acessar continuamente o SAISP, visando antecipar ações de emergência em sua rede de distribuição primária ou secundária.

\footnotetext{
${ }^{12}$ Ver <http://www.cgesp.com.br $>$.

${ }^{13}$ Ver <http://www.saisp.br>.
} 


\section{ASPECTOS LEGAIS}

\subsection{A ERA DA INFORMAÇÃO}

O fato é que os seres humanos se comunicam, e demandam informação. Essa é uma verdade especial do Século XXI, logo se vive hoje na era da sociedade da informação. Esta sociedade caracteriza-se pelo elevado número de atividades produtivas que dependem da gestão de informação e da comunicação entre as pessoas e empresas, com intenso uso de tecnologias multimídias. Tal situação tem se acentuado principalmente porque os modos de produção capitalista interferem nos mecanismos culturais das sociedades. Isso gera complexa interconexão entre as instituições e indivíduos, estimulando e favorecendo novas referências e necessidades de vida.

A era da informação é a era da comunicação de massa, através da convergência tecnológica que elimina os limites entre os meios e que cancela a validade de fronteiras entre serviços e informação. Nessa nova era a informação é também mercadoria e, portanto, pode gerar lucro, nascendo daí o debate sobre a democratização da informação. Conduzindo-nos necessariamente a conceber a inevitabilidade da ação pública e governamental nos setores que transportam e ou divulgam informação, sobretudo pela figura das agências reguladoras (MIRANDA, 2000).

A ocorrência dessa nova era, aliada a crescente dependência da sociedade em relação a energia elétrica ${ }^{14}$, nos remete a importância de discutir o direito à informação, e principalmente sobre a necessidade que a legislação de nosso país possa assegurar este mundo moderno, até porque a informação é uma ferramenta fundamental para o crescimento econômico (LASTRES, 1999). Além disso, do ponto de vista empresarial, não só atender, como também, em alguns casos, exceder dispositivos da legislação vigente, é crucial sob diversos aspectos do marketing. Conseqüentemente, é fundamental analisar a regulamentação passada e vigente no Brasil, e se possível sugerir avanços.

\subsection{BREVE HISTÓRICO}

\subsubsection{De 1880 até 1969}

Nos anos de 1880 a 1900, a eletricidade foi introduzida no Brasil por pequenas firmas privadas que forneciam energia para a iluminação de locais públicos e para diversos tipos de

\footnotetext{
${ }^{14}$ Ver Tabela 2 deste trabalho.
} 
atividades econômicas (mineração, pequenas empresas de manufatura e processamento de determinados produtos agrícolas), e a maior parte da energia era de origem térmica. E dessa maneira o serviço de iluminação elétrica na cidade de São Paulo foi inaugurado em 1887 (BAER, MACDONALD, 1997).

Em 1881, após decisão do Conselho de Estado, era concedida à Telephone Company do Brasil, através do Decreto № 8.065 , a permissão "para fazer negócio de construir e fazer trabalhar linhas telephonicas da cidade do Rio de Janeiro e seus subúrbios e na cidade de Nictheroy”. Esta empresa foi, portanto, a primeira a explorar o serviço público de telefonia no Brasil com fins comerciais. Em 1883 foi instituída a regulamentação para concessão de linhas telefônicas através do Decreto № 8.935 .

Já nos primeiros anos do Século XX, o grupo canadense Sao Paulo Railway, Light and Power Company Ltd. (Light) dominava o mercado de fornecimento de energia elétrica nas cidades de São Paulo e Rio de Janeiro, sendo que outras cidades eram servidas por pequenas firmas em operação, todas com base em arranjo concessionário com os municípios. Cada município utilizava critérios próprios para concessão. Na mesma linha, em São Paulo, em 1896 era inaugurada a Companhia Rede Telefônica Bragantina, também pertencente ao grupo Light.

Os anos 1920 foram caracterizados por um processo ainda maior de concentração do setor elétrico nas firmas maiores, sobretudo nas de propriedade estrangeira. Em 1930, o fornecimento de energia de quase todas as regiões mais desenvolvidas era dominada pela Light e pela American and Foreign Power Co. (AMFORP). Até 1930, o Estado brasileiro, personalizado nos governos municipais, interveio muito pouco no setor, quase sempre apenas regrando os princípios da concessão e reajustes tarifários (BAER, MACDONALD, 1997).

A partir de 1931, o Governo Federal passou a efetuar mudanças institucionais significativas no setor elétrico. As condições da época (Grande Depressão) tornaram possível a publicação em 1934 do Código das Águas através do Decreto Federal № 24.643, decreto esse que se tornou o instrumento básico para o Governo Federal regular o setor de energia elétrica, tirando assim competência dos governos municipais. O Código das Águas incumbiu o Serviço de Águas do Departamento Nacional de Produção Mineral (DNPM), ligado ao Ministério da Agricultura, como o órgão competente do Governo Federal para fiscalizar o serviço de produção, transmissão e distribuição de energia elétrica. 
Portanto, o Código das Águas foi a primeira legislação abrangente do setor elétrico no Brasil visando assegurar serviço adequado, atribuindo possibilidades de multas e taxas de fiscalização, impondo melhoramentos na qualidade e quantidades das instalações, bem como exigindo a divulgação de diversas informações de ordem técnica pelo concessionário.

Todavia, o Código das Águas trouxe como consequência adversa um declínio dos investimentos diretos no setor por parte das empresas estrangeiras nos anos 1930 e 1940, e dessa forma o Brasil começou a experimentar situações de risco de escassez de energia. Assim, a partir do fim da $2^{\underline{a}}$ Guerra Mundial, coube ao Estado fazer a maior parcela de investimentos no setor elétrico, de maneira a sustentar o desenvolvimento industrial do país.

Em 1928, foi inaugurada a primeira central telefônica automática na cidade de São Paulo, serviço público já então sob concessão da empresa privada Companhia Telephonica Brasileira (CTB), sucessora da Companhia Rede Telefônica Bragantina.

De 1939 até 1960, a regulamentação governamental do setor elétrico foi confiada ao Conselho Nacional de Águas e Energia Elétrica (CNAEE) e ao Ministério da Agricultura, quando a competência do CNAEE e DNPM foi transferida para o Ministério das Minas e Energia e ao Departamento Nacional de Águas e Energia Elétrica (DNAEE) através da Lei Federal № 3.782 de 22 de Julho de 1960.

Ocorreu em 1962 a criação do Código Brasileiro de Telecomunicaçoes, através da Lei № 4.117, marcando o início da política nacional para o setor, surgindo também o Conselho Nacional de Telecomunicações (CONTEL) com órgão regulador e fiscalizador.

Em 1965, ocorreu a transformação da Divisão de Águas do DNPM no Departamento Nacional de Águas e Energia (DNAE), através da Lei Federal № 4.094 de 17 de Dezembro de 1965, que reorganizou o Ministério das Minas e Energia. O CNAEE foi mantido.

Foi também nos anos 1960 que começou a ocorrer a gradual nacionalização do setor de energia elétrica no Brasil. Foi criada em 1961 a ELETROBRÁS, holding estatal, fatos que culminaram com a compra da AMFORP (1964) e o Grupo Ligth (1979) pelo governo brasileiro. Deu-se ênfase também à interligação de várias empresas e a construção de linhas de transmissão. Em 1969, deu-se a extinção do Conselho Nacional de Águas e Energia Elétrica (CNAEE), cujas atribuições passaram à competência do DNAEE (Decreto-Lei № 689 de 1969). 
Em 1965, surge a Empresa Brasileira de Telecomunicações (EMBRATEL), estatal federal cujo fim era de possibilitar a interligação das redes telefônicas estaduais e de fazer melhorias nas comunicações internacionais. Em 1968 foi criado o Ministério das Comunicações.

\subsubsection{De 1970 até 1997}

Em 1972, a EMBRATEL completa a implantação do Sistema Básico de Microondas, interligando todos os Estados e Territórios por troncos de rádio microondas. Em Novembro do mesmo ano, instala-se a Telecomunicações Brasileiras S.A. (TELEBRAS), empresa estatal holding do setor, responsável pela modernização das empresas governamentais de serviços públicos de telecomunicações no País, e também por criar diversos padrões para o setor. Os primeiros "orelhões" (telefones públicos nas calçadas) são instalados no Rio de Janeiro e em São Paulo. Em 1973 foi assinada a Ata de Constituição da Telecomunicações de São Paulo S/A (TELESP), que assumiu os serviços da CTB.

Em 17 de Abril de 1978, o DNAEE editou a Portaria № 46, definindo os números máximos no tocante a quantidade e duração de interrupções de fornecimento de energia elétrica.

Em 1990 é publicada a Lei Federal № 8.078, que dispõe sobre a proteção dos consumidores em geral, dando garantias quanto à informação e serviços adequados. No mesmo ano, o Rio de Janeiro torna-se a primeira cidade brasileira a usar a Telefonia Móvel Celular. Em 1993, a telefonia celular chega ao Estado de São Paulo. Em 1995 é implantada a Internet comercial no Brasil.

No entanto, a crise fiscal do Estado brasileiro iniciada no final dos 1970, e a crescente falta de recursos para investimentos aliada a uma onda neo-liberal, levou o governo ao processo de privatização das empresas de serviços públicos, e a liberalização do setor elétrico e de telecomunicações iniciou-se nos meados dos anos 1990.

A Constituição Federal de 1988 forneceu a base dessa mudança, e as Leis das Concessões (Lei Federal № 8.987 de 13 de Fevereiro de 1995 e a Lei Federal № 9.074 de 7 de julho de 1995) regulamentaram o artigo 175 da Constituição, prevendo que nas concessões o usuário poderia participar da supervisão dos serviços, e que as revisões tarifárias considerariam a evolução dos custos das empresas, garantindo assim os investimento necessários para a manutenção do sistema e a melhoria de sua qualidade. 
Em 1996, a Câmara dos Deputados criou um novo órgão regulador para o setor elétrico, a Agência Nacional de Energia Elétrica (ANEEL), substituindo o DNAEE. Em 1997 foi editada a Lei Federal № 9.472 - Lei Geral de Telecomunicações, criando também a Agência Nacional de Telecomunicações (ANATEL), que assumiu as funções do CONTEL.

A privatização do setor elétrico e das telecomunicações ocorreu em um clima amigável ao investidor estrangeiro, dado o contexto econômico da época e a necessidade urgente brasileira do capital estrangeiro para o ajuste fiscal. Uma decorrência desse fato é que a privatização de diversas empresas do setor elétrico ocorreu na ausência de um arcabouço regulatório claramente definido. Dessa forma, a regulação deficitária dos segmentos considerados monopólios naturais mereceria redobrada atenção nos anos seguintes, o que levou os governos estaduais a melhor atuar na fiscalização desses serviços.

A primeira privatização do setor elétrico aconteceu em Julho de 1995. Finalizado o processo, a ELETROBRAS existe hoje como sociedade de capital misto, permanecendo sócia de algumas distribuidoras estaduais. Em 1995 é iniciado o processo de privatização do setor de telecomunicaçoes, concluído em 1998. A empresa TELEBRAS ainda existe hoje em função do seu contencioso judicial e micro-acionário remanescente.

\subsubsection{De 1997 aos tempos atuais}

No Estado de São Paulo, através da Lei Complementar № 833 de 17 de Outubro de 1997, foi instituída a Comissão de Serviços Públicos de Energia (CSPE). Na área de energia elétrica, a CSPE foi criada para exercer a fiscalização técnica, comercial e econômicofinanceira das concessionárias de distribuição de energia elétrica que atuam no Estado de São Paulo, por meio de convênio de delegação e descentralização firmado com a ANEEL. A CSPE é uma entidade autárquica, vinculada à Secretaria de Energia, Recursos Hídricos e Saneamento, criada tendo como objetivo melhorar a qualidade do serviço prestado.

Em 12 de Novembro de 1997, o DNAEE publicou a Portaria $\mathrm{N}^{\circ} 466^{15}$. Foi o início de uma onda que garantiria novos direitos de informação ao consumidor de energia elétrica. Em 17 de Novembro do mesmo ano, começa a operar o primeiro serviço celular digital nacional da Banda B, em Brasília.

Em 2000, inicia-se a implantação do serviço de Internet em banda larga em São Paulo. No mesmo ano, a Telesp Celular o serviço WAAAP, sendo a primeira operadora no Estado de São Paulo a oferecer o serviço de Internet no celular.

\footnotetext{
${ }^{15}$ Posteriormente substituída pela Resolução da ANEEL N № 456 de 29 de Novembro de 2000.
} 
Em 2001, a ANATEL começa a apurar as metas de qualidade e universalização do acesso ao sistema de telefonia fixa brasileira, caracterizando a primeira década do Século XXI como sendo de explosão da oferta e demanda nos meios de comunicação. A Lei № 10.438 , de 26 de abril de 2002, alterada pela Lei № 10.762, de 11 de novembro de 2003, em seu Art. 14 atribuiu à ANEEL a tarefa de estabelecer metas de universalização do acesso ao serviço público de energia elétrica.

Até 2004, quando a ANEEL publicou Resolução Normativa № 54/2004 (melhor dispondo sobre o atendimento telefônico ao consumidor de energia elétrica na situações de interrupções de emergência), a CSPE realizou espontaneamente fiscalizações pontuais planejadas sobre a qualidade desses serviços nas concessionárias, em consideração as reclamações de consumidores junto à Ouvidoria, e as notícias publicadas pela mídia e solicitações diversas. Mesmo ocorrendo lacuna normativa sobre o assunto até 2004, através dos processos abertos pela Ouvidoria a CSPE programou fiscalizações específicas quanto ao atendimento prestado pelas centrais telefônicas das concessionárias de distribuição, avaliando serviço adequado com relação aos aspectos de facilidade de acesso, presteza, correção das informações e retornos oferecidos. Essa fiscalização usava o arcabouço legal existente até então para caracterização de serviço telefonico inadequado.

Por fim, o Governo Federal e as respectivas agências reguladoras empenham-se atualmente em criar concorrência entre as empresas privadas de distribuição de eletricidade, bem como entre as operadoras de telecomunicações.

Ressaltam-se a seguir leis e normas pertinentes a este trabalho. Como regra, o estudo segue inicialmente pelas leis mais abrangentes, e depois pelas normas específicas do setor elétrico.

\subsection{LEIS FEDERAIS}

\subsubsection{Constituição Federal}

De acordo com a Constituição da República Federativa do Brasil (1988), há o Artigo $5^{\circ}$ da Constituição, inciso XXXII, dando direitos ao cidadão:

“[...] todos tem direito a receber dos órgãos públicos informações de seu interesse particular, ou de interesse coletivo ou geral, que serão prestados no prazo da lei, sob pena de responsabilidade."

O Artigo $174^{\circ}$ trata da ordem econômica e financeira, e rege os princípios gerais da atividade econômicas: 
"[...] Como agente normativo e regulador da atividade econômica, o Estado exercerá, na forma da lei, as funções de fiscalização, incentivo e planejamento, sendo este determinante para o setor publico e indicativo para o setor privado."

No Artigo $175^{\circ}$, escreveu-se sobre a concessão de serviços públicos."

“[...] incumbe ao poder público, na forma da lei, diretamente ou sob regime de concessão ou permissão, sempre através de licitação, a prestação dos serviços públicos. A lei disporá de ... II - os direitos dos usuários; ... IV - a obrigação de manter serviço adequado."

O serviço público, como atividade econômica, e estando sob concessão de empresas privadas ou empresas públicas, deve manter um serviço adequado, e ser físcalizado pelo Estado brasileiro.

\subsubsection{Lei $\mathrm{N}^{\mathbf{0}} \mathbf{8 . 0 7 8}$}

Nota-se definições importantes na Lei Federal № 8.078 (1990), que dispõe sobre a proteção do consumidor. Observa-se em seu Capítulo I que:

“[...] Art. $2^{\circ}$ Consumidor é toda pessoa física ou jurídica que adquire ou utiliza produto ou serviço como destinatário final.

Art. $3^{\circ}$ Fornecedor é toda pessoa física ou jurídica, pública ou privada, nacional ou estrangeira, bem como os entes despersonalizados, que desenvolvem atividade de produção, montagem, criação, construção, transformação, importação, exportação, distribuição ou comercialização de produtos ou prestação de serviços.

$\S 1^{\circ}$ Produto é qualquer bem, móvel ou imóvel, material ou imaterial.

$\S 2^{\circ}$ Serviço é qualquer atividade fornecida no mercado de consumo, mediante remuneração, inclusive as de natureza bancária, financeira, de crédito e securitária, salvo as decorrentes das relações de caráter trabalhista."

Pela mesma lei foram definidos os deveres do Estado brasileiro para com o consumidor, que obriga a este primeiro usar de instrumentos de enriquecimento da qualidade nos serviços públicos. Em seu Capítulo II (Da Política Nacional de Relações de Consumo), há que:

“[...] Art. $4^{\circ}$ A Política Nacional de Relações de Consumo tem por objetivo o atendimento das necessidades dos consumidores, o respeito a sua dignidade, saúde e segurança, a proteção de seus interesses econômicos, a melhoria da sua qualidade de vida, bem como a transparência e harmonia das relações de consumo, atendidos os seguintes princípios: 
... V - incentivo à criação, pelos fornecedores, de meios eficientes de controle de qualidade e segurança de produtos e serviços, assim como de mecanismos alternativos de solução de conflitos de consumo;

... VII - racionalização e melhoria dos serviços públicos.

[...] Art. 22 Os órgãos públicos, por si ou suas empresas, concessionárias, permissionárias ou sob qualquer outra forma de empreendimento, são obrigados a fornecer serviços adequados, eficientes, seguros e, quanto aos essenciais, contínuos."

Ainda na mesma lei, no Capítulo III (Dos Direitos Básicos do Consumidor), foram garantidos os direitos do consumidor quanto à informação e serviços adequados:

“[...] Art. $6^{\circ}$ São direitos básicos do consumidor:

... III - a informação adequada e clara sobre os diferentes produtos e serviços, com especificação correta de quantidade, características, composição, qualidade e preço, bem como sobre os riscos que apresentem;

... X - a adequada e eficaz prestação dos serviços públicos em geral.

\subsubsection{Lei № 8.987}

Pela Lei Federal № 8.987 (1995), que dispõe sobre o regime de concessão e permissão da prestação de serviços públicos previsto no Art. 175 da Constituição Federal, há dois artigos de maior interesse para o consumidor do setor elétrico, pois neles há uma definição exata para serviço adequado, e neles são limitadas as obrigações ao prestador de serviço público quanto a continuidade da entrega do serviço. Constata-se que:

“[...] Art. $6{ }^{\circ}$ Toda concessão ou permissão pressupõe a prestação de serviço adequado ao pleno atendimento dos usuários, conforme estabelecido nesta Lei, nas normas pertinentes e no respectivo contrato.

$\S 1$ o Serviço adequado é o que satisfaz as condições de regularidade, continuidade, eficiência, segurança, atualidade, generalidade, cortesia na sua prestação e modicidade das tarifas.

$\S 2{ }^{\circ} \mathrm{A}$ atualidade compreende a modernidade das técnicas, do equipamento e das instalações e a sua conservação, bem como a melhoria e expansão do serviço.

$\S 3^{\circ}$ Não se caracteriza como descontinuidade do serviço a sua interrupção em situação de emergência ou após prévio aviso, quando:

I - motivada por razões de ordem técnica ou de segurança das instalações;

[...] Art. $7^{\circ}$. Sem prejuízo do disposto na Lei $\mathrm{N}^{\mathrm{o}}$ 8.078, de 11 de setembro de 1990, são direitos e obrigações dos usuários:

I - receber serviço adequado." 
Por estes dois artigos observa-se que o fornecimento de energia elétrica pode ser interrompido sem caracterizar serviço inadequado, contanto que sejam utilizadas técnicas modernas de controle e gestão do evento, além da cortesia com consumidor durante o episódio.

\subsubsection{Lei № 9.074}

Na Lei Federal № 9.074 (1995) está estabelecido normas para outorga e prorrogações das concessões e permissões de serviços públicos, e regulamenta em seu Art. $25^{\circ}$ a necessidade de estabelecer padrões mínimos de qualidade do concessionário de serviço publico.

\footnotetext{
"Art. 25. As prorrogações de prazo, de que trata esta Lei, somente terão eficácia com assinatura de contratos de concessão que contenham cláusula de renúncia a eventuais direitos preexistentes que contrariem a Lei $\mathrm{N}^{\mathrm{o}}$ 8.987, de 1995.

$\S 1^{\circ}$ Os contratos de concessão e permissão conterão, além do estabelecido na legislação em vigor, cláusulas relativas a requisitos mínimos de desempenho técnico do concessionário ou permissionário, bem assim, sua aferição pela fiscalização através de índices apropriados.

$\S 2^{\circ}$ No contrato de concessão ou permissão, as cláusulas relativas à qualidade técnica, referidas no parágrafo anterior, serão vinculadas a penalidades progressivas, que guardarão proporcionalidade com o prejuízo efetivo ou potencial causado ao mercado."
}

No setor elétrico da distribuição já foram criados, dentre outros, índices próprios de fiscalização, como os de continuidade DIC, DEC, FIC e o FEC, atendendo o Art. 25 da Lei 9.074. Mas visando a eventual extinção da concessão, serviços inadequados ou insatisfação generalizada dos consumidores não são razões suficientes para tanto.

\subsubsection{Lei № 9.427}

A Lei Federal № $9.427(1996)^{16}$ instituiu a Agência Nacional de Energia Elétrica ANEEL. No seu Art. $2^{\circ}$, define-se:

"[...] A Agência Nacional de Energia Elétrica - ANEEL tem por finalidade regular e fiscalizar a produção, transmissão, distribuição e comercialização de energia elétrica, em conformidade com as políticas e diretrizes do governo federal.“

\footnotetext{
${ }^{16}$ Posteriormente complementado pelo Decreto Lei № 2.325 de 6 de Outubro de 1997.
} 
E na seqüência serão analisadas as resoluções que a ANNEL criou exercendo o seu papel de órgão regulador, no sentido da defesa e da garantia de informações aos consumidores.

\subsection{RESOLUÇÕES DA ANEEL}

\subsubsection{RN № $456 / 2000$}

A Resolução Normativa № 456 (2000) da ANEEL, estabelece, de forma atualizada e consolidada, as Condições Gerais de Fornecimento de Energia Elétrica. Ficou estabelecido em seu Art. 83 que a fatura de energia elétrica deverá conter as seguintes informações:

“[...] o) número de telefone da Central de Teleatendimento e/ou outros meios de acesso à concessionária para solicitações e/ou reclamações;

p) número de telefone da Central de Teleatendimento da Agência Reguladora Estadual conveniada com a ANEEL, quando houver; e

q) número 0800612010 da Central de Teleatendimento da ANEEL."

E no Art. 98 determinou que:

"[...] A concessionária deverá dispor de estrutura de atendimento adequada às necessidades de seu mercado, acessível a todos os consumidores da sua área de concessão possibilitando a apresentação das solicitações e reclamações.

$\S 1^{\circ}$ : Estrutura adequada é aquela que possibilita ao consumidor ser atendido em todas as suas solicitações e reclamações sem que, para tanto, tenha que se deslocar do município onde reside."

\subsubsection{RN No 24 / 2000}

Pela Resolução Normativa № 24 (2000) da ANEEL, foram estabelecidas as disposições relativas à Continuidade da Distribuição de energia elétrica às unidades consumidoras. Em seu Art. $2^{\circ}$, foi reconhecido que:

“[...] A continuidade dos serviços públicos de energia elétrica deverá ser supervisionada, avaliada e controlada por meio de indicadores coletivos que expressem os valores vinculados a conjuntos de unidades consumidoras, bem como indicadores individuais associados a cada unidade consumidora e ponto de conexão."

No Art. $3^{\text {o }}$ foram definidos termos importantes que serão utilizados ao longo deste trabalho, como Dia Crítico, Interrupção de Longa Duração, Interrupção Programada, Interrupção de Urgência e Interrupção de Situação de Emergência, ressaltando: 
- Interrupção de Longa Duração: "Toda interrupção do sistema elétrico com duração maior ou igual a 3 (três) minutos".

- Interrupção de Situação de Emergência: "Interrupção motivada por caso fortuito ou de força maior, a ser comprovada documentalmente pela concessionária de distribuição, desde que não se caracterize como de sua responsabilidade técnica, por falta de manutenção ou de investimentos em seu sistema”.

- Dia Crítico: “Dia em que a quantidade de ocorrências, associadas à Interrupção em Situação de Emergência, em um determinado conjunto de unidades consumidoras, superar a média acrescida de três desvios padrões dos valores diários. A média e o desvio padrão a serem usados serão os relativos aos 24 (vinte e quatro) meses anteriores ao mês em curso".

No Art. $24^{\circ}$ é definido também Serviço Essencial como sendo serviço ou atividade caracterizado como de fundamental importância para a sociedade, desenvolvido em unidade consumidor. A mesma Resolução № 24 exemplificou os serviços essenciais:

$$
\text { "[...] }
$$

- unidade operacional do serviço público de tratamento de água e esgotos;

- unidades hospitalares, institutos médico-legais, centros de hemodiálise e de armazenamento de sangue, centros de produção, armazenamento e distribuição de vacinas e soros antídotos;

- unidade operacional de serviço público de comunicações;

- centro de controle público de tráfego aéreo, marítimo e urbano;

- instalações que atendam ao sistema rodoferroviário e metroviário;

- unidade operacional de segurança pública;

- câmaras de compensação bancária e unidades do Banco Central do Brasil."

No Art. $4^{\circ}, \S 2^{\circ}$, estão sujeitas as distribuidoras:

“[...] para cada conjunto afetado por interrupções de longa duração deverão ser registradas as seguintes informações:"

I - número de unidades consumidoras do conjunto em cada mês da apuração; e

II - código de identificação do conjunto".

No Art. $4^{\circ}, \S 3^{\circ}$, obrigou-se as distribuidoras que:

“[...].para cada interrupção de longa duração ocorrida no conjunto deverão ser registradas as seguintes informações:"

I - fato gerador;

II - data, hora e minutos do início e restabelecimento da interrupção; e

III - número de unidades consumidoras atingidas em cada interrupção".

No Art. $14^{\circ}$ é exigido que: 
“[...] a concessionária deverá avisar a todos os consumidores da respectiva área de concessão sobre as interrupções programadas, informando a data da interrupção, horário de início e término."

E finalmente segundo o Art. $16^{\mathrm{o}}$

“[...] a concessionária de distribuição deverá dispor de sistemas ou mecanismos de atendimento emergencial, acessíveis aos consumidores, para que os mesmos apresentem suas reclamações quanto a problemas relacionados ao serviço de distribuição de energia elétrica, sem prejuízo do emprego de outras formas de sensoriamento automático da rede.

$\S 1^{\circ}$ Para que o atendimento emergencial seja considerado adequado, a concessionária deverá dispor de, no mínimo, serviço de atendimento telefônico gratuito, disponíveis todos os dias durante 24 (vinte e quatro) horas, acessível de qualquer localidade de sua área de concessão."

\subsubsection{RN № 615 / 2002}

Para os consumidores de baixa tensão, a ANEEL criou a Resolução Normativa № 615 (2002) que visa estabelecer modelo de Contrato de Prestação de Serviço Público de Energia Elétrica para Unidades Consumidoras Atendidas em Baixa Tensão.

Foi definido que:

“[...] INTERRUPÇÃO DO FORNECIMENTO: desligamento temporário da energia elétrica para conservação e manutenção da rede elétrica e em situações de casos fortuitos ou de força maior."

A distribuidora apura todas as interrupções de fornecimento, mas para fins de penalização as Interrupções de Emergência não são consideradas pelo órgão regulador.

Porém, nota-se grande avanço no direito do consumidor quanto a informação. Entre os principais direitos do CONSUMIDOR estão:

“[...]

1. Receber energia elétrica em sua unidade consumidora, nos padrões de tensão e de índices de continuidade estabelecidos;

6. Ter o serviço de atendimento telefônico gratuito disponível 24 (vinte e quatro) horas por dia para a solução de problemas emergenciais;

8. Ser informado, no prazo máximo de 30 (trinta) dias, sobre providências quanto às solicitações ou reclamações;

17. Ser informado sobre a ocorrência de interrupções programadas, por meio de jornais, revistas, rádio, televisão, ou outro meio de comunicação, com antecedência mínima de 72 (setenta e duas) horas; 
18. Ser informado por documento escrito e individual, sobre as interrupções programadas, com antecedência mínima de 5 (cinco) dias úteis, quando existir na unidade consumidora pessoa que dependa de equipamentos elétricos indispensáveis à vida.

Todavia, entre os principais deveres do CONSUMIDOR estão:

“[...]

Manter os dados cadastrais atualizados junto à CONCESSIONÁRIA".

ou seja, uma ferramenta legal de apoio às concessionárias para conduzir seus consumidores a fornecer dados importantes para viabilizar a comunicação efetiva entre as partes.

\subsubsection{RN № 57 / 2004}

No sentido de melhor especificar o conteúdo das RN № 24 e № 615, a ANEEL criou a Resolução Normativa № 57 (2004), estabelecendo as condições de atendimento por meio de Central de Teleatendimento (CTA) das concessionárias ou permissionárias, critérios de classificação de serviços e metas de atendimento.

Esta resolução é de extrema importância para este trabalho, e pelo momento é necessário citar somente alguns poucos artigos. A ANEEL, nesta resolução, reconheceu que:

"[...] existe a necessidade de padronizar os procedimentos referentes ao serviço de teleatendimento prestado pelas concessionárias ou permissionárias de distribuição de energia elétrica aos solicitantes, visando seu aprimoramento, sem prejuízo da obrigação de instalar e manter os postos de atendimento pessoal reconhecidos nas revisões tarifárias periódicas."

Nos artigos $3^{\circ}, 6^{\circ}, 7^{\circ}$ e $9^{\circ}$ está o conteúdo básico da norma:

“[...] Art. $3^{\circ}$ A concessionária deverá disponibilizar atendimento telefônico, sem prejuízo da oferta de atendimento pessoal por meio de postos de atendimento, fixo ou móvel;

II - atendimento até o segundo toque de chamada;

III - acesso em toda área de concessão, incluindo os municípios atendidos a título precário, segundo regulamentação;

IV - estar disponível todos os dias, 24 (vinte e quatro) horas por dia; e

$\mathrm{V}$ - todo atendimento deverá gerar um número de identificação ao solicitante (protocolo), a ser informado ao mesmo antes do término do atendimento.

$\S 1^{\circ}$ Os atendimentos serão classificados conforme disposto no Anexo I desta Resolução.

$\S 2^{\circ}$ A concessionária deverá disponibilizar condições para que o solicitante acompanhe o atendimento prestado pela mesma, que compreende o acesso a todos 
os dados registrados sob o número de protocolo informado, mediante consulta telefônica, ou por escrito, desde que solicitado.

[...] Art. $6^{\circ}$ É permitido à concessionária a utilização de atendimento automatizado, via URA, com oferta de menu de opções de direcionamento ao solicitante.

Parágrafo único. Em caso de recebimento da chamada diretamente via URA ou por menu de opções, deverão ser respeitadas as seguintes características:

I - atendimento até o segundo toque de chamada, caracterizando o recebimento da chamada;

II - a última opção do menu principal deverá ser a de espera por atendimento por atendente e obrigatoriamente disponibilizada como opção de número 9 (nove);

III - o tempo decorrido entre o recebimento da chamada e o anúncio da opção de espera para atendimento por atendente será de, no máximo, 30 (trinta) segundos;

IV - deverá ser facultada ao solicitante a possibilidade de acionar a opção desejada a qualquer momento, sem que haja necessidade de aguardar o anúncio de todas as opções disponíveis; e

$\mathrm{V}$ - o menu principal poderá apresentar menus consecutivos ou sub-menus aos solicitantes, à exceção das opções de emergência e de atendimento por atendente.

[...] Art. $7^{\circ}$ A concessionária deverá disponibilizar ao solicitante a possibilidade de acesso diferenciado entre atendimento comercial e emergencial, incluindo as seguintes opções:

I - números telefônicos diferenciados para atendimento comercial e de emergência; ou II - número telefônico unificado com atendimento prioritário para emergência.

[...] Art. $9^{\circ}$ A qualidade do atendimento telefônico ao solicitante será mensurada por indicadores, tendo em vista padrões estabelecidos para períodos mensais e diários." 


\section{ALGUNS ASPECTOS DA COMUNICAÇÃO EM TEMPO REAL}

\subsection{DEFINIÇÃO}

O termo comunicação apresenta diversas definições. Uma definição mais geral é que se trata de um processo de emissão, recepção ou afluência de conteúdo informativo, síncrono ou assíncrono, através de protocolo comum. A comunicação de massa é um termo mais especializado, focado nas relações com amplas audiências, não segmentadas e uniformizadas, e se contrapõe à comunicação pessoal (GOVERNPUB, 2006).

A comunicação pode ser ainda unilateral ou bilateral, interativa, intencional ou não intencional, interna ou externa, multimídia. Também pode ser verbal ou não verbal. E o mais importante, a comunicação pode ser em TEMPO REAL.

O conceito de COMUNICAÇÃO EM TEMPO REAL está ligado ao tempo de resposta entre as partes. Um sistema de comunicação em tempo real apresenta tempo de resposta reduzido, ou imediato, e é considerado de missão crítica. Muitas vezes sistemas de comunicação em tempo real se confundem com sistemas de alta performance ou capacidade. E tecnologicamente, a moderna existência de sistemas de comunicação em tempo real está associada a computação em tempo real, onde uma grande quantidade de dados pode ser processada quase instantaneamente.

Os componentes dos sistemas de comunicação são vários. Basta lembrar que a comunicação ocorre quando o emissor (ou fonte da informação) emite uma mensagem (ou sinal) ao receptor (ou decodificador), através de um canal (ou meio). O receptor interpretará a mensagem que pode ter chegado até ele com algum tipo de barreira (ruído, bloqueio, filtragem) e, a partir daí, dará o feedback ou resposta, completando o processo de comunicação.

A mensagem é o objeto da comunicação. Dependendo do contexto, o termo pode ser aplicado tanto ao conteúdo da informação quanto à sua forma de apresentação. Existem diversas formas de um emissor transmitir uma mensagem para o receptor, como será melhor visto no Capítulo 6. 


\subsection{O COMPORTAMENTO DO CONSUMIDOR: MOBILIDADE E CONVERGÊNCIA}

Destacam-se informações divulgadas em 2006 pelo Instituto Brasileiro de Geografia e Estatística (IBGE), conforme aponta a Tabela 2. Segundo o IBGE (2006), 85,8\% de homens brasileiros com mais de 15 anos de idade possuíam telefone móvel celular no final de 2005 . Da mesma maneira, pesquisas do IBGE também indicam que 13,7\% dos domicílios tinham microcomputador com acesso à Internet em 2005. Na região Sudeste este número eleva-se para $18,9 \%$. Outra indicação precisa deste novo mundo móvel e convergente observa-se na revista especializada TELETIME, que informa que em 2005 havia 81,239 milhões de usuários de telefonia móvel no Brasil (93\% desse número em zona urbana) contra 52,226 milhões de usuários de telefonia fixa. De quase 6 mil cidades brasileiras, das quais 3 mil com cobertura de celular, um total de 2.648 já consta com serviço de dados via telefonia móvel disponível, e o ritmo é crescente (TELETIME, 2006).

Dados de meados de 2006 da Agência Nacional de Telecomunicações (ANATEL) ampliam estes números, indicando que ao final de 2005 havia 94.904 .998 terminais móveis do Serviço Móvel Celular (SMC) e Serviço Móvel Pessoal (SMP). Segundo a ANATEL (2006), houve um crescimento geral de 31,4\% de terminais em 2005 em relação ao ano anterior. Um crescimento maior se deu especificamente nas Bandas $\mathrm{D}$ e $\mathrm{E}^{17}$. Comprova-se também que a presença de computadores móveis e portáteis como os Personal Digital Assistances (PDAs) e celulares multimídias têm contínua expansão no mercado brasileiro.

Por outro lado, a quantidade de usuários de TV por assinatura permanece inalterada na faixa de 3 e 4 milhões de assinantes desde o ano de 2001, segundo a própria ANATEL; o que, em parte, explica o cenário atual que favorece o aumento de teledensidade multimídia e convergente muito mais personificado nos modernos aparelhos celulares.

\footnotetext{
${ }^{17}$ Bandas concedidas às operadoras celulares TIM Celular e Oi, que adotam o padrão GSM de rede. A Banda D cresceu 57,9\%, e a Banda E cresceu 137,7\% em 2005 em relação ao ano anterior, segundo a ANATEL (2006).
} 
Tabela 2: Pesquisa Nacional por Amostra de Domicílios do IBGE

\begin{tabular}{|c|c|c|c|c|c|c|}
\hline \multirow[b]{2}{*}{ ITENS PESQUISADOS } & \multicolumn{3}{|c|}{ BRASIL } & \multicolumn{3}{|c|}{ REGIÃO SUDESTE } \\
\hline & $\begin{array}{c}\text { Ano } \\
2004(\%)\end{array}$ & $\begin{array}{c}\text { Ano } \\
2005(\%)\end{array}$ & $\begin{array}{l}\text { Variação } \\
(\%)\end{array}$ & $\begin{array}{c}\text { Ano } \\
2004(\%)\end{array}$ & $\begin{array}{c}\text { Ano } \\
2005(\%)\end{array}$ & $\begin{array}{l}\text { Variação } \\
(\%)\end{array}$ \\
\hline Domicílios com energia elétrica & 96,8 & 97,2 & 0,41 & 99,4 & 99,4 & 0,00 \\
\hline Domicílios com linha telefônica & 65,4 & 71,6 & 9,48 & 75,8 & 81,2 & 7,12 \\
\hline Domicílios com televisão & 90,3 & 91,4 & 1,22 & 92,5 & 96,1 & 3,89 \\
\hline Domicílios em rádio $\mathrm{AM} / \mathrm{FM}$ & 87,8 & 88,0 & 0,23 & 92,5 & 92,4 & $-0,11$ \\
\hline $\begin{array}{l}\text { Domicílios com } \\
\text { microcomputador }\end{array}$ & 16,3 & 18,6 & 14,11 & 22,0 & 24,8 & 12,73 \\
\hline $\begin{array}{l}\text { Domicílios em microcomputador } \\
\text { e acesso a Internet }\end{array}$ & 12,2 & 13,7 & 12,30 & 16,8 & 18,9 & 12,50 \\
\hline $\begin{array}{l}\text { Homens com } 15 \text { anos ou mais } \\
\text { que possuem telefone celular }\end{array}$ & ND & 85,8 & ND & ND & 85,2 & ND \\
\hline $\begin{array}{l}\text { Mulheres com } 15 \text { anos ou mais } \\
\text { que possuem telefone celular }\end{array}$ & ND & 80,6 & ND & ND & 81,2 & ND \\
\hline
\end{tabular}

Fonte: IBGE, 2006. ND: Não Disponível.

Esse cenário traduz-se numa demanda e expectativa também crescentes por parte dos consumidores em termos de disponibilidade de informações precisas em tempo real. Combinando os novos padrões de comunicação com consumidores mais exigentes, a indústria global prevê o início de um círculo virtuoso entre novos serviços e novos equipamentos. $\mathrm{O}$ modelo tradicional de comunicação das Centrais de Teleatendimento - as quais recebem uma chamada telefônica vinda da rede pública de telefonia fixa originada por um consumidor abstrato - irá ser substituído por um modelo muito mais rico em experiências colaborativas que acontecerão por variados mecanismos de comunicação, afirma a INTEL (2004b).

Confirmando este cenário, a Associação Brasileira de E-Business (2006) indica que 80\% das grandes empresas brasileiras consideram a Internet como imprescindível para relacionamento com o consumidor e como modelo de valor agregado aos serviços, pesquisa assinalando também um estágio inicial de interação presente nos portais na Web das empresas. A grande tendência está no provimento de conteúdo para dispositivos móveis com $76 \%$ de pretensão de uso, seguido pelo Web Chat, com 59\%. 


\subsection{OS VEÍCULOS DE COMUNICAÇÃo CERTOS PARA CADA PÚBLICO}

A utilização de meios de comunicação de massa implica logicamente em organizações geralmente amplas, complexas, com grande número de profissionais. Mas talvez a mais típica característica dos meios de comunicação de massa é a possibilidade que apresentam de atingir simultaneamente uma vasta audiência, ou, dentro de breve período de tempo, atingir centenas de milhares de consumidores ${ }^{18}$.

De acordo com o IBGE (2006) a televisão e rádio são juntos os meios de acesso a informação em tempo real mais difundidos nos domicílios do Brasil, e estando em terceiro lugar o telefone fixo. Mas ao contrário da televisão e rádio, o telefone não é originalmente um veículo de comunicação de massa, e sim de comunicação pessoal. Uma extensão deste fato é que a quantidade de telefones fixos hoje no Brasil é menor que a quantidade de telefones móveis.

Segue um exemplo da diversidade de audiência: um consumidor de energia elétrica da classe Comercial, o qual se pode supor terá disponível diversas mídias para contato; já o consumidor Residencial terá restrições de acesso a um amplo conjunto de mídias, principalmente os de classe menos favorecidas economicamente. $\mathrm{O}$ consumidor que tem uma atividade essencial (hospitais e departamento de polícias, por exemplo) também terá disponíveis meios de comunicação diferenciados do consumidor Residencial e Comercial.

Exemplo que nos conduz a uma questão fundamental: qual é o meio de comunicação mais adequado para manter informado o maior número de consumidores possíveis numa situação de desligamento em massa? A conclusão deste trabalho sugere uma resposta a esta pergunta.

Como alternativa e complemento aos inevitáveis centros de teleatendimento multimídia, algumas distribuidoras no Brasil estão implantando (ou já possuem implantado) redes de atendimento pessoal, embora estas não sejam capazes de dar vazão à comunicação de massa necessária nas situações de interrupção de emergência nos Dias Críticos. Essas redes de atendimento pessoal são constituídas principalmente de:

- Agências próprias, já tradicionais desde quando o setor era de domínio estatal;

- Megalojas, localizadas em pontos estratégicos de grande afluência do público, capacitadas para prestarem a maioria dos serviços que o consumidor requisita.

\footnotetext{
${ }^{18}$ Essa audiência, além de heterogênea e geograficamente dispersa é, por definição, constituída por membros anônimos para a fonte, ainda que a mensagem esteja dirigida especificamente para uma parcela determinada de público.
} 


\subsection{A MENSAGEM E A LINGUAGEM DE COMUNICAÇÃO}

Em qualquer sistema de informação, para que a transmissão de mensagem tenha sucesso, alguns cuidados devem ser adotados de modo a evitar barreiras. Uma dessas barreiras é a linguagem. A linguagem do emissor deve ter proximidade com a linguagem do receptor (RABAÇA, 2001).

No processo de comunicação com consumidores de energia elétrica ocorre sempre uma dificuldade adicional que é o da escolha de linguagens adequadas para com os diferentes interlocutores. Criar uma interface (sonora ou visual) apropriada depende também da mensagem e seu conteúdo. Isso porque a linguagem adequada se refere ao nível de conhecimento do receptor, o seu nível cultural, a sua instrução. Quando a linguagem utilizada pelo emissor em uma determinada mensagem está em um nível acima da que seria adequada para o receptor, existe incompatibilidade de níveis de linguagem e a apreensão da mensagem em sua totalidade pelo receptor é impossível. O desenvolvimento da mensagem para com um consumidor de energia elétrica deve considerar esta matéria da linguagem, tentando buscar que o emissor (distribuidoras de energia elétrica) esteja sempre próximo, se torne aparentemente "íntimo", e seja interessante para que o seu receptor (consumidor) entenda e aceite a mensagem (ARANHA; 1986).

Parece ser padrão entre as distribuidoras brasileiras que o maior número de consumidores esteja na classe Residencial, embora o maior consumo encontre-se no segmento Industrial, como demonstram dados da Secretaria da Energia e Recursos Hídricos do Governo do Estado de São Paulo (2006) mostrados no Gráfico 2. Portanto, em qualquer programa de desenvolvimento de linguagem de comunicação, os consumidores residenciais devem ter prioridade.

Esses fenômenos da comunicação podem ser encarados de uma maneira mais exata e formal. Um método de análise científica foi criado por Claude E. Shannon (SHANNON, 1948), que fundou um sub-ramo da matemática que lida com sistemas de comunicação, transmissão de dados, criptografia, codificação, ruídos, correção de erros, compressão de dados, etc. 

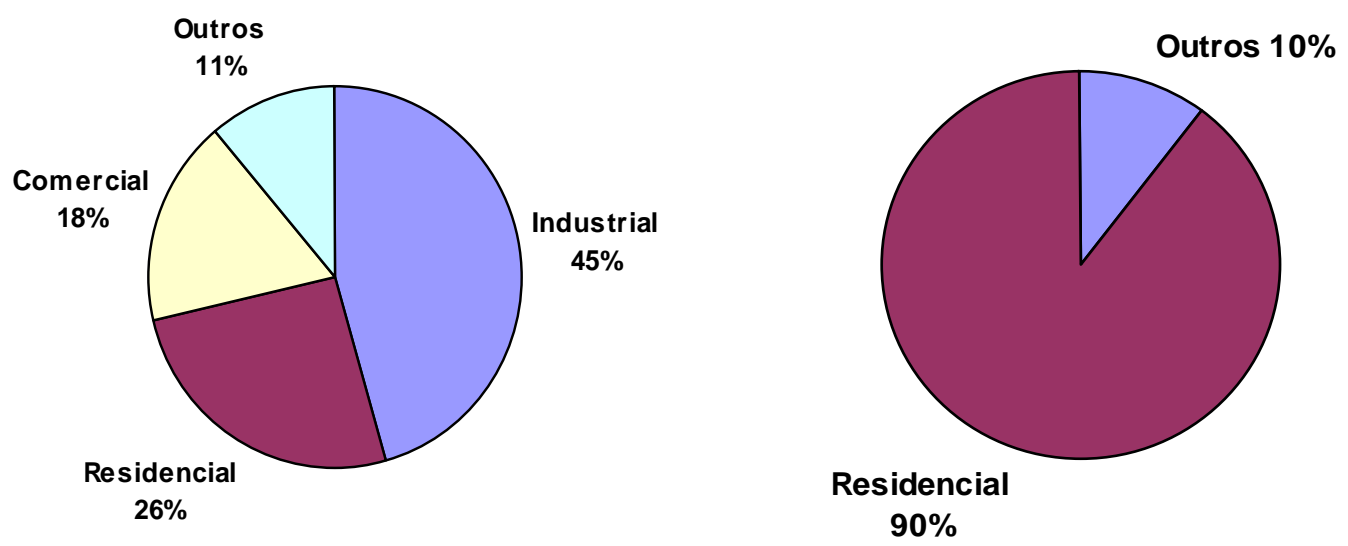

Fonte: Governo do Estado de São Paulo, 2006

Gráfico 2: Porcentual de Consumo de Energia por Classe e Porcentual de Consumidores em Setembro de 2006, respectivamente, para o Estado de São Paulo.

Entretanto, independente de qualquer método científico, a experiência adquirida por cada concessionária é de vital importância para definir a solução do problema de linguagem, pois o perfil dos consumidores também varia de acordo com a região de concessão. Ou seja, cada concessionária deve buscar conhecer seus consumidores. Para tanto há modernas técnicas de Marketing de Relacionamento que podem ser auxiliar neste tópico, como indica o item o 5.7 .

\subsection{A RESPOSTA PRÓ-ATIVA ÀS SITUAÇÕES DE EMERGÊNCIA}

As emergências são crises, e a gestão de crises envolve a comunicação com o público externo. No entanto, constata-se que a maioria das organizações não confere muita relevância à resposta a situações de emergência e muitas vezes socorre-se de um profissional de relações públicas apenas para o contato com os órgãos de imprensa (GAMA, 2000), deixando de lado o seu público consumidor.

Os fatos abordados em 3.4 nos remetem a Stocker (1997), que sugere que a gestão de crise, por definição, é a preparação e aplicação de estratégias e táticas de comunicação que possam prevenir ou modificar o impacto de grandes acontecimentos. A emergência é aquela situação que exige o uso de todas as capacidades da empresa, sob stress extremo e com constrangimentos severos de tempo, podendo afetar inclusive a credibilidade pública e a satisfação do consumidor. 
Quando uma emergência de grandes proporções ocorre, ela ultrapassa todas as fronteiras da organização para se refletir na opinião pública que irá ajuizar a maneira como a organização soube solucionar a situação. Os órgãos de imprensa geralmente assumem uma postura crítica. A posição que a empresa deve assumir é de uma postura pró-ativa e não reativa no campo da comunicação com seu público externo (JEFKINS, 1994).

\subsection{A SEGURANÇA DA INFORMAÇÃO}

A comunicação em tempo real depende dos equipamentos de informação, que por sua vez dependem da Segurança da Informação. Um incidente de segurança pode causar impacto direto e negativo no processo de comunicação, com prejuízos. Um incidente de segurança pode estar associado a um prejuízo financeiro, mas geralmente também prejudica a imagem das empresas, e por isso é um item relevante de marketing ${ }^{19}$.

O Institute of Electrical and Electronics Engineers (IEEE, 2005) abrange o tema da Segurança da Informação em três tópicos principais:

- Confidencialidade da Informação: Mecanismo de prevenção contra o uso não autorizado de informação e busca evitar a quebra de sigilo de dados;

- Integridade da Informação: Mecanismo preventivo contra as alterações da informação e busca evitar a modificação não autorizada de dados;

- Disponibilidade da Informação: Mecanismo que previne a suspensão ou lentidão no acesso a informações ou recursos; busca evitar a subtração de recursos e comprometimento da qualidade de serviços prestados.

Dos três tópicos acima, o item Disponibilidade da Informação é o de maior interesse neste trabalho. Segundo a PROMOM (2005b), muitos fatores contribuem para a perda de disponibilidade de informação. O principal deles é a falha dos recursos computacionais devido aos incidentes de segurança. Esses incidentes são gerados por diversos motivos:

- O primeiro deles é o número de vulnerabilidade dos equipamentos, como os existentes em sistemas operacionais de computadores e de banco de dados;

- Outro fator é que é trabalhoso e custoso mitigar essas vulnerabilidades. A complexidade dos sistemas de informação é assustadora;

- Cresce também a velocidade e alcance das falhas de segurança, ou seja, os incidentes não crescem somente em número. Acontecem de forma mais rápida e devastadora;

\footnotetext{
${ }^{19}$ Em última instância, um incidente de segurança prejudica a organização de cumprir sua missão e de gerar valor para o acionista e para os clientes que esta serve.
} 
- Outro fator importante é a questão social. Mais de dois terços das falhas de segurança são causadas intencionalmente por funcionários internos à organização afetada;

- As fronteiras de segurança também se expandem, na medida em que os consumidores de uma distribuidora de energia ganham a possibilidade de comunicarem-se através de diversos meios de contato. A delimitação dessas fronteiras é um problema complexo, pois pode também limitar o acesso às informações em tempo real, prejudicando o relacionamento com o consumidor.

A segurança da informação pode ser mais bem garantida, de acordo com a PROMOM (2005b), atuando na preparação das pessoas que administram os sistemas, modificando e aprimorando processos e introduzindo ferramentas tecnológicas. Em termos de processos, é importante criar uma política de segurança de informação, definindo quais informações e equipamentos são essenciais, confidenciais, e qual será métrica de desempenho desses itens.

Outros métodos de mitigação de falhas de segurança e disponibilidade foram recentemente apresentados por Lau (2006). Foram citados ainda no item 3.3 tópicos modernos de Gestão de Tecnologia de Informação que vêm de encontro com a necessidade de Segurança de Informação.

\subsection{O MARKETING ONE TO ONE VERSUS MARKETING DE MASSA}

Segundo Rizzo (2003), a evolução do relacionamento com o consumidor no século XX foi conduzida sob três orientações principais: orientação da produção, orientação do produto, orientação das vendas. Todas elas sob a ótica do marketing de massa.

De forma mais recente, já no final do século XX, Don Peppers e Martha Rogers divulgaram em seu livro The One to One Future (1993) o conceito de orientação pelo Marketing One to One $e^{20}$.

Marketing One to One é uma metodologia de marketing fundamentada no tratar clientes diferentes de formas diferentes. Veio como resposta à globalização da economia, a competição em áreas antes monopolizadas, e ao comércio eletrônico, fatores que estão provocando grande impacto no mundo dos negócios e na maneira como as empresas devem se relacionar com seus clientes.

\footnotetext{
${ }^{20}$ Marketing One to One também pode se chamado de Marketing em Tempo Real, ou Marketing de Relacionamento.
} 
O Marketing One to One é fundamentado em quatro regras: identifique seus clientes, diferencie seus clientes, interaja com seus clientes e personalize o atendimento. Quanto mais personaliza-se, mais valor agregado entrega-se ao cliente, que vê conveniência e qualidade.

$\mathrm{Na}$ verdade, o Marketing One to One foi uma redescoberta de Peppers, pois este conceito remonta aos primórdios do comércio de serviços e produtos. Nesse tempo, o fornecedor conhecia cada cliente pelo nome, onde viviam, que tipo de produtos necessitavam e quando os necessitavam. Sabia como queriam que os produtos fossem entregues, como queriam pagar suas contas e quanto tinham de dinheiro para gastar. Conscientemente ou não, o fornecedor dividia seus clientes em grupos de maior ou menor valor para o negócio. Dessa forma, personalizava os serviços e produtos, para que fossem adequados às necessidades de cada cliente (PEPERS AND ROGERS GROUP, 2001). Porque o fornecedor fazia isso? Principalmente para criar um diferencial competitivo ${ }^{21}$.

O Marketing One to One se contrapõe ao Marketing de Massa, que predomina atualmente desde a Revolução Industrial. O Marketing de Massa trata dos mercados de massa (ou mesmo até mesmo de mercados de monopólio natural), ou seja, da oferta de artigos e serviços comuns, vendidos no atacado e depois no varejo, com padrão satisfatório para a maioria dos consumidores, com preços fixados em nível acessível (RIZZO, 2003). Em vez de lidar com cada cliente de forma individual para conhecer suas necessidades, uniformiza-se os serviços e produtos. É a comoditização dos bens e serviços.

Parte do Marketing de Massa está em extinção, junto com a tendência da segmentação dos mercados. Um dos motivos é que somente de forma recente o Marketing One to One tornou-se viável para ser implantado para a maioria dos grandes mercados, principalmente devido aos baixos custos dos recursos de Tecnologia de Informação. As mídias, também estão se fragmentando, e a comunicação com o consumidor de forma maciça está se tornando onerosa e dificultosa, exigindo dessa forma estratégias típicas do Marketing One to One.

No Marketing One to One, o contact center é o núcleo de interação com os clientes. Nele, a capacidade da empresa em criar e manter diálogos com seus clientes define o futuro e a duração desse relacionamento. Em um contact center focado no cliente, o importante é medir a eficácia no desenvolvimento de aprendizado mútuo (PEPERS AND ROGERS, 2001), e não a produtividade em relação a quantidade de chamadas versus tempo de atendimento. Nesse moderno contact center é possível incluir como métrica, por exemplo, quantos problemas foram resolvidos na primeira ligação do consumidor.

\footnotetext{
${ }^{21}$ Para o setor elétrico, particularmente na concessão da distribuição, a competição está sendo lentamente introduzida após a desregulamentação desse segmento.
} 


\section{O CONTEXTO DA TECNOLOGIA DA INFORMAÇÃO A SERVIÇO DA COMUNICAÇÃO}

\subsection{PRINCIPAIS TECNOLOGIAS DE INFORMAÇÃO}

A seguir, são identificadas, relacionadas e brevemente descritas as mais avançadas tecnologias de comunicação a serviço da comunicação, ressaltando que não é o foco esgotar o assunto da tecnologia de informação nesta dissertação.

- Computer Telephony Integration (CTI): CTI é uma tecnologia criada para unir o poder de processamento de informações dos sistemas computacionais ao poder de alcance e acessibilidade dos sistemas de telefonia baseados em Private Automatic Branch eXchange (PABX). A necessidade do CTI surge do fato de que o telefone ainda é o meio mais fácil e acessível de se comunicar à distância; porém, nenhum sistema telefônico sozinho atinge o grau de sofisticação de processamento de informações atingido por um sistema computacional. Para uma empresa, unir as duas tecnologias faz com que seu poder de comunicação interna e externa, bem como sua eficiência e eficácia, aumente consideravelmente (INTEL, 2001). Um dos padrões mais conhecidos de CTI é o Computer-Supported Telephony Application (CSTA). Também são largamente usadas as Application Programming Interfaces (API) em conjunto com o CTI (WALTER, 1998).

O CTI também pode integrar outras mídias além do Telefone como, por exemplo, Fax, Email e Web Chat, assim como chamadas entrantes e saintes. Também integra estas mídias com outras plataformas, como plataformas de Customer Relationship Management (CRM), de Work Force Management (WFM), de Enterprise Resource Planning (ERP), ou mesmo de Field Force Automation (FFA), conforme mostram as Figuras 7 e 8 . Essa capacidade inerente permite que a distribuidora de energia elétrica construa um contact center verdadeiramente multimídia, capaz de prover serviços de atendimento de qualidade superior a um baixo custo operacional (ERICSSON, 2004b). 


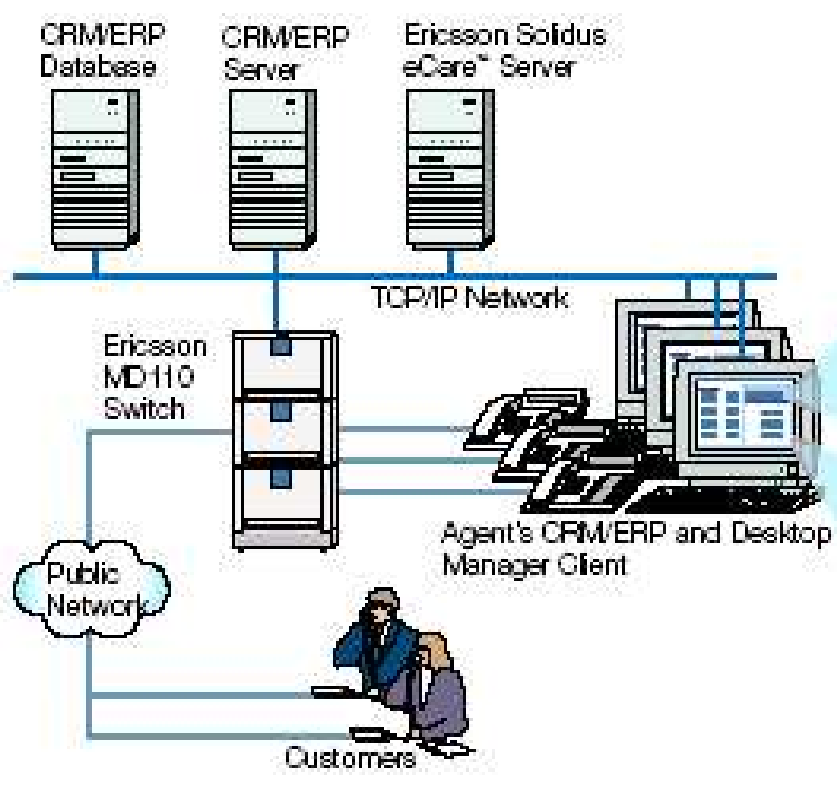

CRM/ERP Architecture

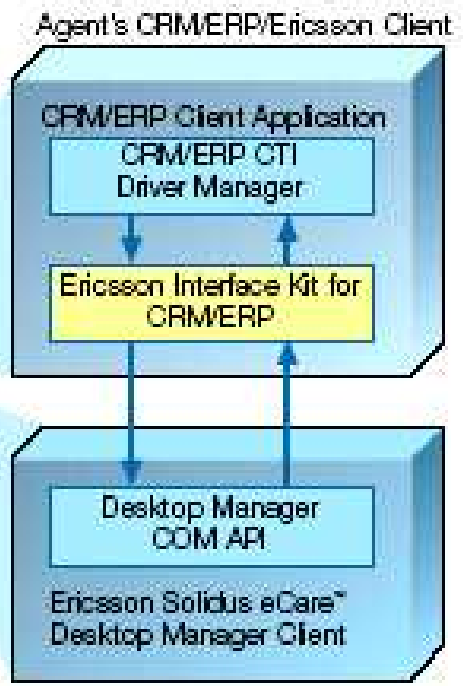

Fonte: ERICSSON, 2004b.

Figura 7: Exemplo de arquitetura CRM utilizando PABX integrado via CTI com telas do atendente.

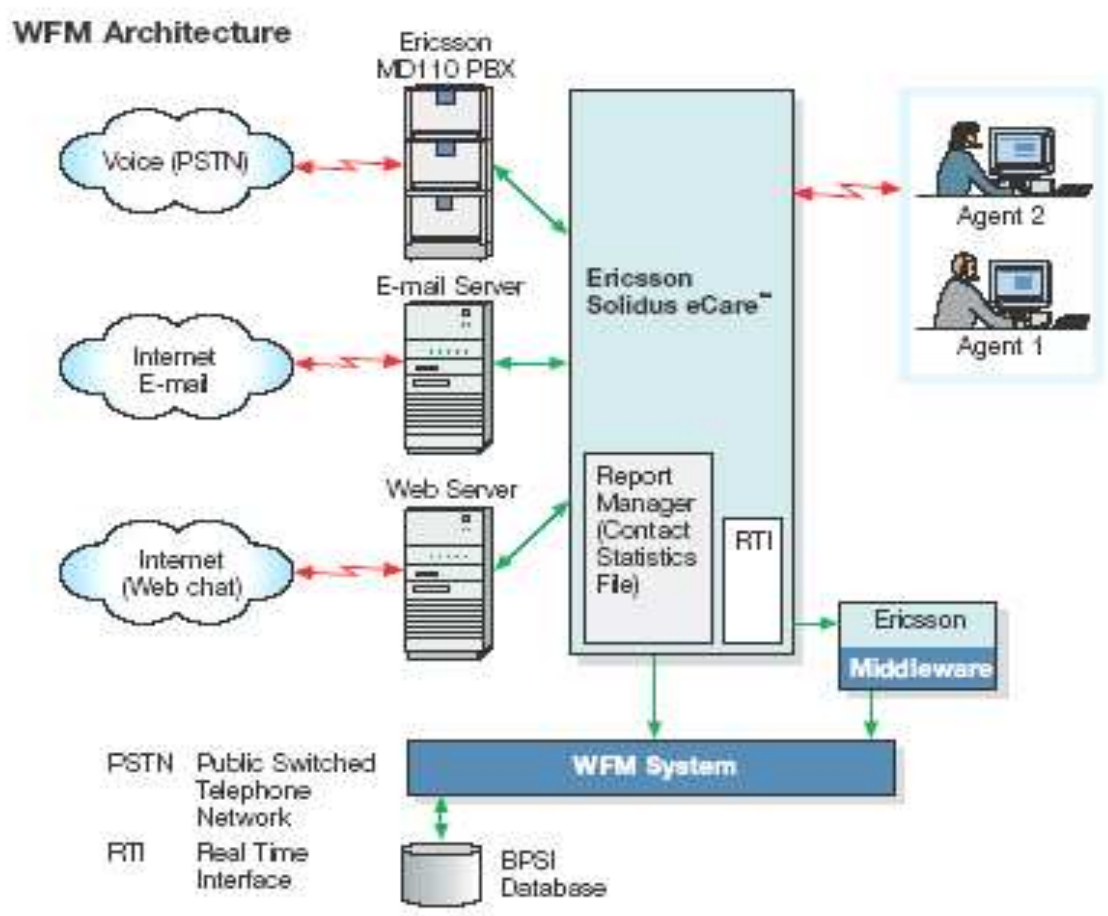

Fonte: ERICSSON, 2004b.

Figura 8: Exemplo de arquitetura WFM utilizando um PABX, um Servidor de E-mail e de Web Chat, integrado via CTI para telas do atendente. 
- $\quad$ Reconhecimento de Voz: Softwares deste tipo permitem que computadores equipados com microfones interpretem a fala humana, por exemplo, para transcrição ou como método de comando por voz. Tais sistemas podem ser classificados por requererem ou não que o usuário treine o sistema a reconhecer seus padrões particulares de fala, por ter a habilidade de reconhecer fala contínua ou por requerer que o usuário fale pausadamente, e pelo tamanho do vocabulário que é capaz de reconhecer (pequeno, da ordem de dezenas a centenas de palavras, ou grande, com milhares de palavras). Sistemas que requerem pouco treinamento podem capturar continuamente a fala com um amplo vocabulário em um ritmo normal com uma precisão de cerca de $98 \%$ (duas palavras erradas em cem), e sistemas que não requerem treinamento podem reconhecer um número pequeno de palavras (por exemplo, os dez dígitos do sistema decimal), de acordo com a INTEL (2001).

- Text-to-speech (TTS): Uma forma de comunicar-se com os clientes é via a tecnologia TTS. TTS é uma modificação dos softwares de reconhecimento de voz, transformando textos em discursos. Pode ser usado para ler e-mails, mensagens de texto ou textos baseados em Web. Nas novas formas de TTS o discurso não é completamente gerado a partir dos algoritmos que traduzem texto, mas sim também em conjuntos de sons prégravados, conforme indica a INTEL (2001).

- Knowledge Base: É uma base de dados que é utilizada principalmente por Agentes Virtuais (não humanos), como para a funcionalidade de resposta automática para emails ou para Short Messages Services (SMS) e, também para apresentar sugestões de respostas aos agentes durante atendimento de Chat. Vários tipos de conteúdo podem ser adicionados a esta base, incluindo textos, diagramas, links para páginas Web e mensagens institucionais. Informações podem ser continuamente acrescentadas a esta base, formando um valioso recurso tanto para consumidores quanto para os atendentes, que podem obter automaticamente informações cada vez mais completas. Com esta ferramenta, as empresas podem montar uma base de dados composta por perguntas e respostas mais freqüentes, e palavras-chave correspondentes. À medida que a base vai sendo enriquecida com mais informações, as aplicações de atendimento automático na Internet e resposta automática de e-mails e SMS tornam-se mais precisas, finalizando mais atendimentos sem intervenção humana (ERICSSON, 2005). 
- Web Services: O desejo pela redução de custos conduziu as empresas para uma única rede de informação, uma rede mais moderna e de mais ampla possibilidade de desenvolvimento de aplicações integradas. Essa necessidade por uma única infraestrutura de comunicação está levando as empresas e os centros de atendimento a desenvolverem aplicações baseadas na Internet, conforme nos atenta a INTEL (2004a). A Web é um novo padrão de acesso universal, no qual diversas transações são possíveis. A essas transações pela Web se denomina Web Services, e a principal característica de um Web Service é que este pode ser universalmente acessado por qualquer dispositivo que se comunique com a Internet. O protocolo de comunicação mais utilizado para acesso é o HyperText Transfer Protocol (HTTP), mas também pode ser feito pelo Simple Mail Transfer Protocol (SMTP) ou pelo File Transfer Protocol (FTP). A Figura 9 é um exemplo destes serviços.

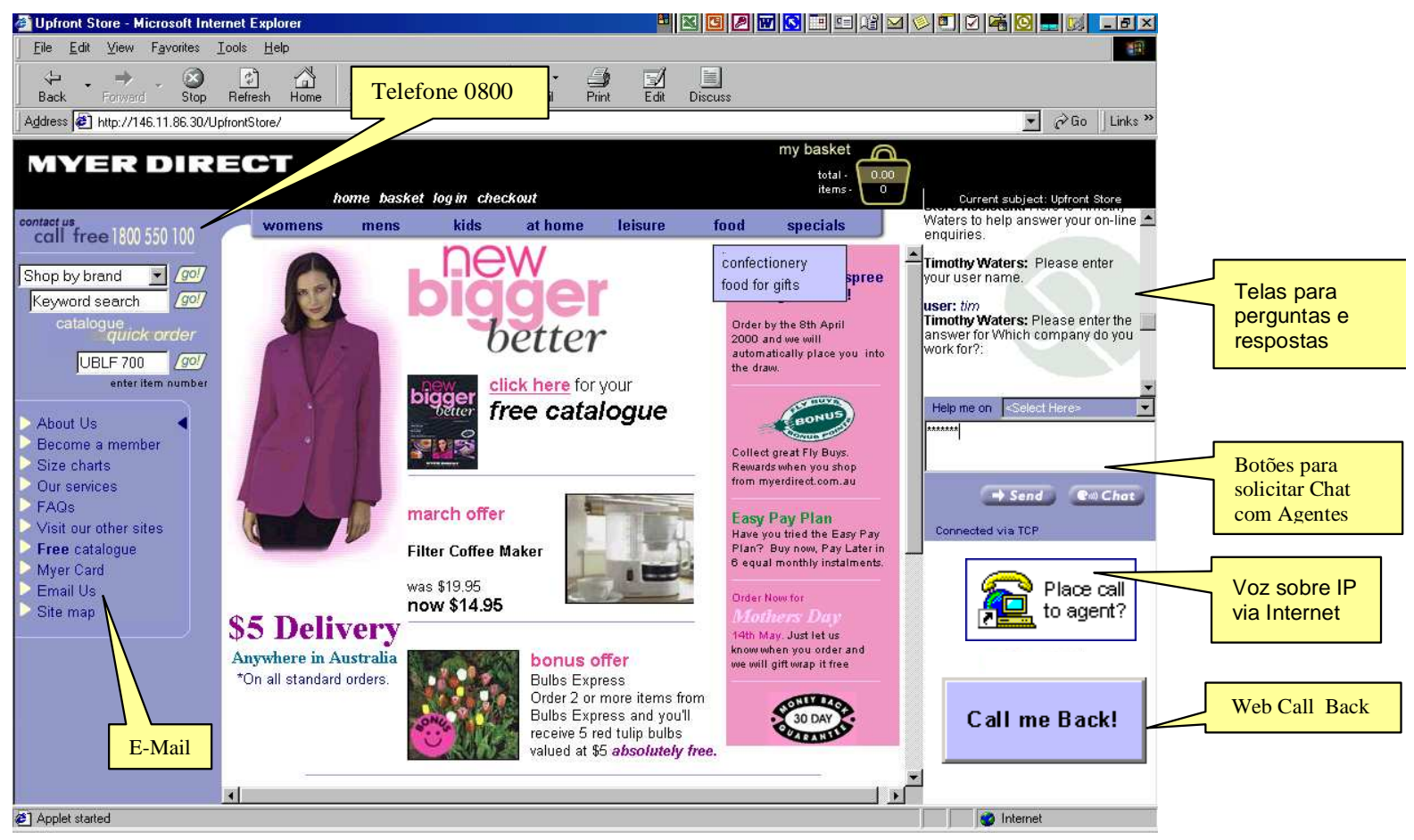

Fonte: ERICSSON, 2005.

Figura 9: Exemplo de website integrado com as múltiplas mídias. 
- Internet Móvel: A comunicação sem fio é a maior tendência global das telecomunicações (ERICSSON, 2004a), ou seja, será a era da mobilidade ${ }^{22}$. De forma mais abundante, a Internet Móvel está sendo oferecida pelas concessionárias de telecomunicações que possuem a autorização da ANATEL de prestarem o Serviço Móvel Pessoal (SMP) ou Serviço Móvel Celular (SMC) (em suas várias bandas) através de terminais móveis celulares que utilizam as redes celulares de nova geração. Outra forma de acesso a Internet Móvel, mas ainda não tão abundante, é através das redes de padrão Wirelles Fidelity (WiFi), que são redes do tipo Internet Protocol (IP) sem fio de alta velocidade, transferindo dados e voz por rádio em frequiências não licenciadas (PROMOM, 2005a). Para se ter acesso à Internet Móvel através de uma rede WiFi devese: a) estar no raio de ação de um ponto de acesso (normalmente um hotspot) ou em um local público que opere uma rede sem fio conectada a Internet; e b) usar um dispositivo móvel, como um computador portátil (laptop ou Pocket PC) com capacidades de comunicação sem fio compatível com o padrão Wi-Fi, ou mesmo um smartphone (ver Figura 10). Uma terceira forma de acessar a Internet Móvel é usando o padrão criado pelo WiMax, que adicionalmente oferece aos usuários a habilidade de comunicação de vídeo, provendo dessa forma interatividade adicional (GARCIA, 2005).

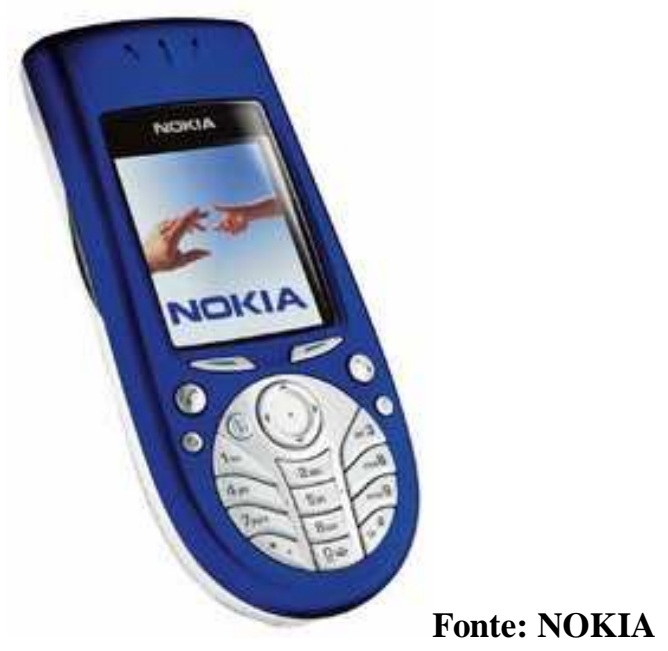

Figura 10: Smartphone da NOKIA, modelo 3260.

\footnotetext{
${ }^{22} \mathrm{O}$ termo mobilidade aqui se refere ao caso urbano, ou seja, no deslocamento dentro das áreas metropolitanas. Em geral o usuário está em ambiente aberto (outdoor). Nesse cenário, as redes celulares ainda são predominantes.
} 
- $\quad$ Short Message Service (SMS): é o nome dado ao serviço de mensagens de até 160 caracteres para comunicadores móveis (celulares, Pocket PCs, smartphones) (ver Figura 11). É um serviço de comunicação que surgiu em 1991 na Europa, através das redes celulares Global System Mobile (GSM) que na época já incluía em seus serviços iniciais a transmissão das mensagens de texto. Atualmente as redes celulares Code Division Multiple Access (CDMA) também dispõem desse serviço. Ao redor do mundo, especialmente nos EUA, o SMS é amplamente utilizado para prover conteúdos diferenciados tais como notícias e alertas. Os clientes inscritos para receberem um SMS com este conteúdo diferenciado pagam normalmente uma taxa fixa ou variável, conforme o tipo de serviço. As tecnologias de redes evoluíram e uma variedade de serviços foi agregada, incluindo serviços de informação, tais como indicadores econômicos.

O processo de envio e recebimento de SMS é simples. Para o sistema que manda as mensagens através de um computador conectado à Internet, o processo é semelhante ao do envio de um e-mail, com a possibilidade de encaminhar uma mesma mensagem para uma lista de destinatários, por exemplo. Para quem recebe o SMS a mensagem aparece na tela do celular ou de um computador móvel logo após o envio. É ideal para quando é desejado que as informações transmitidas cheguem rápido ao seu destinatário (o tempo médio do envio e recebimento no celular é de até 10 segundos) e precisa ser lida no momento do recebimento (a taxa de leitura de um SMS é de quase 100\%) (NOKIA, 2006).

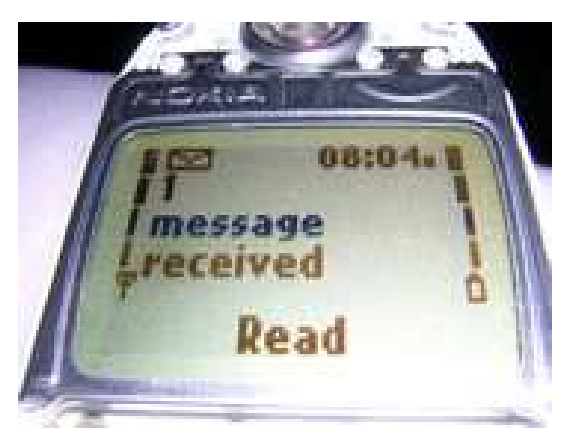

Fonte: NOKIA, 2006

Figura 11: $O$ recebimento de um SMS em celular.

Segundo Nogueira (2005), o SMS, integrado com um sistema de comunicação fixa permite:

- Envio de uma única mensagem a vários usuários; 
- Notificações tais como confirmação de entrega de mensagens, televoto, etc.;

- Política de tentativas, em caso de usuário com a linha ocupada e terminais que não atendem.

Nogueira (2005) ainda observa que outros exemplos de serviços possíveis dentro do SMS:

- Broadcast: um provedor de conteúdo pode enviar mensagens tais como: anúncios de publicidade, Bolsa de Valores, notícias de tempo, esportes etc., a centenas ou milhares de usuários;

- E-Mail para SMS: cada usuário pode receber e-mails (limitado a 640 caracteres e sem anexos) dentro de um endereço tipo mailto:123456@telecom-sms.com.br ;

- Roteamento de mensagens para outro número, por exemplo, o usuário pode transferir a mensagem fixa para o número de seu celular ou para o número de sua casa caso esteja em férias;

- Ativação ou desativação de outros serviços: o usuário pode desabilitar ou habilitar um serviço enviando uma mensagem a um número especial que provê esta facilidade.

- $\quad$ Multimedia Messaging Service (MMS): uma tecnologia que permite aos terminais celulares, PDAs (ver Figura 12) e smartphones enviar e receber mensagens multimídia. É uma evolução do SMS, e da mesma maneira, o MMS permite a distribuição automática e imediata das mensagens pessoais. Entretanto, diferentemente do SMS, o MMS permite ao usuário de celular enriquecer suas mensagens incorporando som, imagens e outros conteúdos elaborados (superiores a 160 caracteres), transformando-as em mensagens visuais e sonoras personalizadas, ou seja, oferece ampliação do conteúdo das mensagens. Com MMS, não só é possível enviar mensagens multimídia de telefone para telefone, como também de telefone para e-mail e vice-versa, além de outros serviços como comércio eletrônico, download de arquivos, acesso a Internet via Wirelles Application Protocol (WAP), e integração de softwares da categoria Enterprise Information. Esse recurso aumenta consideravelmente as possibilidades da comunicação móvel para recebimento de informações em tempo real. O MMS é independente da portadora, o que significa que não está limitado às redes Global System Mobile (GSM) ou CDMA (Code Division Multiple Access), mas geralmente envolvem esses serviços das operadoras concessionárias do Serviço Móvel Celular (SMC) ou do Serviço Móvel Pessoal (SMP). 


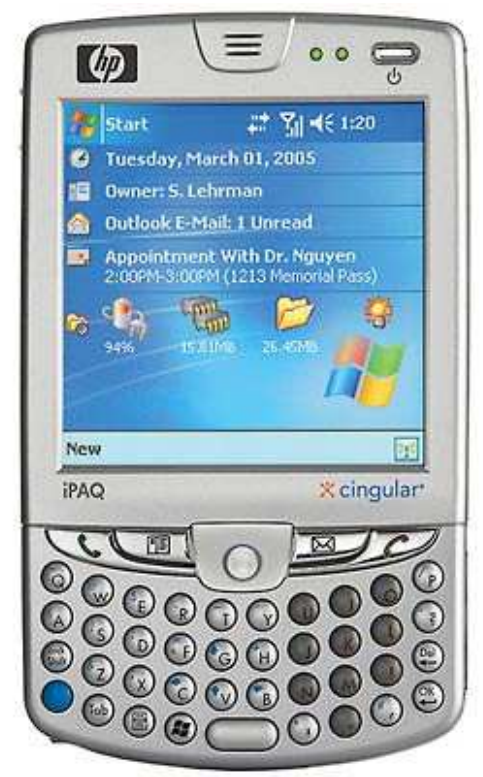

Fonte: Hewlett-Packard

Figura 12: Pocket PC que suporta MMS e Internet Móvel (iPACK 6900)

- Session Initiation Protocol (SIP): é um padrão da Internet Engineering Task Force (IETF), um protocolo de comunicação para estabelecer chamadas e conferências através de redes IP. A sua principal característica é que o estabelecimento da chamada (sessão) ou o seu término é independente do tipo de mídia ou aplicação que será usada; uma chamada pode utilizar diferentes tipos de dados, incluindo voz, dados, áudio, vídeo e muitos outros formatos, ou seja, é um protocolo multimídia. O SIP também tem a habilidade de responder a uma chamada com um tipo diferente de mídia: permite, por exemplo, que uma voz seja respondida por uma página da web ou por um e-mail. Outro recurso interessante é a "informação de presença" - o usuário pode opcionalmente deixar indicar que está presente (disponível para atender a chamada) ou ausente (não disponível para atender a chamada) para os outros usuários do sistema. O SIP, junto aos CTI links, permite integração com os sistemas legados ${ }^{23}$ dos centros de atendimento tradicionais, de forma a construir sistemas de comunicação multimida. Exemplos notáveis incluem o Windows Messenger da Microsoft Cooporation, que transforma um microcomputador em um software de telefone com as ferramentas adicionais de vídeo e Web Chat. Outro exemplo desta tecnologia é a disponibilização de um canal de comunicação de voz para clientes dentro de uma página Web, de forma que a voz percorra a Internet e chegue ao PABX da empresa. Esse serviço é chamado de click-todial pela empresa norte-americana NET.com, conforme exemplo da Figura 13.

\footnotetext{
${ }^{23}$ Ver item 7.3.2.
} 


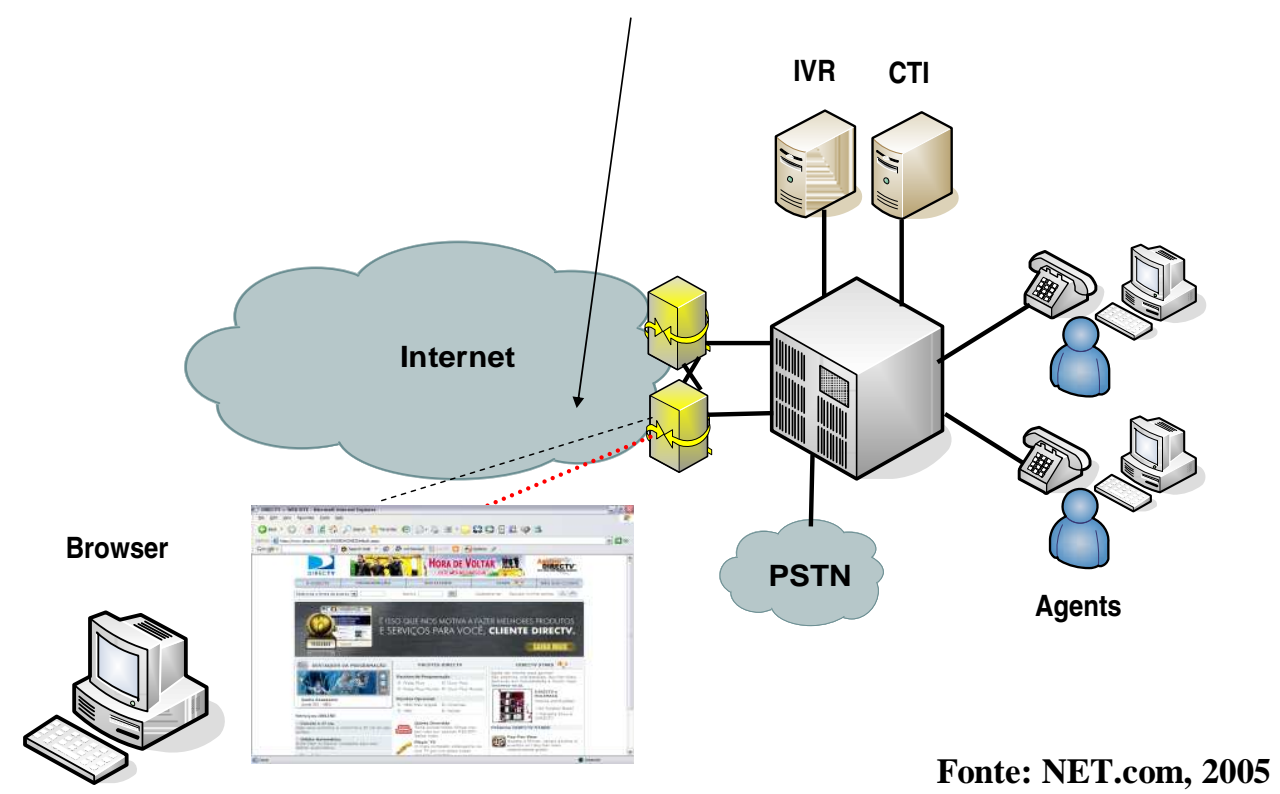

Figura 13: Click-to-dial via Browser integrado em centros de atendimento com SIP e CTI.

- VoiceXML: O crescimento da WWW foi catalisador do desenvolvimento dos padrões HTML de programação, e também da aceitação de padrões de serviços de telefonia pela Internet. O VoiceXML (Voice eXtensible Markup Language) é o maior exemplo dessa tendência e esforço de padronização, de acordo com o VoiceXML Forum (2006). O VoiceXML permite que sejam providos serviços na Web através de interfaces de voz e telefonia conjugadas às interfaces de texto. É uma linguagem que suporta conjuntamente algoritmos de reconhecimento de voz, de sintetização de voz através de técnicas de Text-to-speech, reconhecimento de Dual Tone MultiFrequential (DTMF), SIP, SMS, e controle de outros equipamentos por CTI. Pode-se desenvolver sistemas completos de atendimento automático usando essa tecnologia, o que significa novos e amplos serviços para os clientes, conforme indica a Figura 14. Devido às características dessa tecnologia, o acesso às bases de dados também é facilitado (INTEL, 2004a, 2004b). 


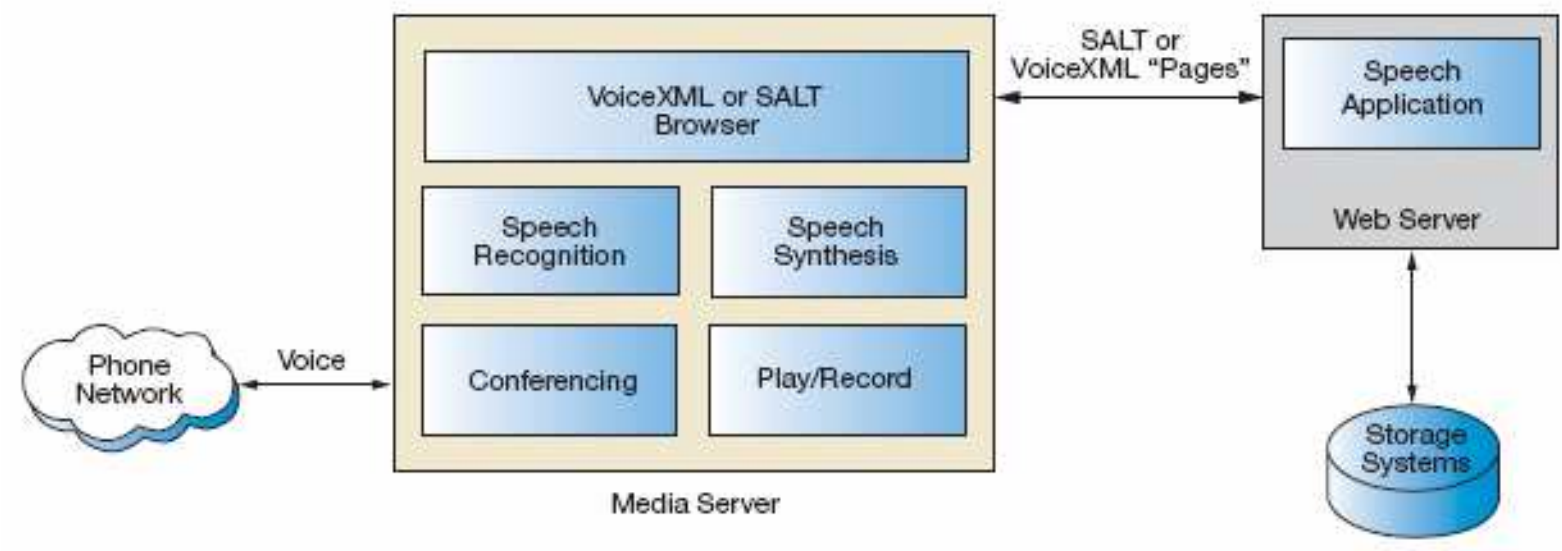

Fonte: INTEL, 2004a.

Figura 14: Exemplo de arquitetura Web para integração de voz e dados, via XML.

- Java: A tecnologia Java foi criada para ser processada dentro de dispositivos heterogêneos, visando integração com a Internet. Desde seu lançamento, em maio de 1995, a plataforma Java foi adotada rapidamente. O Java tornou-se popular e hoje possui seu ambiente de execução presente em web browsers, mainframes, celulares, palmtops e smart cards, entre outros, sempre através dos Applets Java ou dos Java Scripts. No Brasil, por exemplo, a maioria das instituições bancárias utiliza a tecnologia Java para construir seus home banks, que são acessados por milhares de usuários diariamente. Grandes websites como o eBay utilizam Java para garantir alta performance. Interessante é notar que os códigos em Java são programas que não são traduzidos para a linguagem de máquina como outras linguagens compiladas, mas sim para uma representação intermediária, chamada de bytecodes (AMORIM, 2005). Os bytecodes são interpretados por máquinas virtuais Java (Java Virtual Machine) (Sun Microsystems, 2006).

\subsection{PRINCIPAIS APLICAÇÕES NOS CONTACT CENTERS}

As tecnologias de informação não são suficientes em si sem que sejam desenvolvidos sistemas integrados que aproveitem essas tecnologias de forma útil e específica ao serviço desejado. Ou seja, é a tecnologia aplicada que é a verdadeira necessidade das distribuidoras de energia elétrica para enfrentar o problema da comunicação em tempo real com o seu consumidor. A lista a seguir indica algumas dessas aplicações:

- $\quad$ DAC em PABX;

- URA;

- Discadores Automáticos; 
- Auto envio de Fax;

- Auto resposta de Fax;

- $\quad$ Auto resposta de email;

- $\quad$ Auto resposta de SMS;

- Formulários na Web;

- Auto envio de SMS;

- Auto envio de email;

- Web Chat;

- Agentes virtuais;

- Web call back;

- Interceptação de chamadas.

A seguir são descritas as aplicações acima listadas, e o que estas possibilitam.

- Distribuidor Automático de Chamadas (DAC) em PABX: um PABX com a aplicação de DAC, ou em inglês Automated Call Distribuition (ACD), consiste em um comutador de ligações telefônicas capaz de receber chamadas telefônicas dos clientes, estabelecer grupos de atendimento distintos e filas de espera conforme cada grupo e, posteriormente, conforme a ordem de chegada e prioridades definidas, distribuir as chamadas para os atendentes conforme o número do serviço chamado ou de acordo com regras pré-estabelecidas de roteamento (ALENCAR, 1998).

A principal regra de roteamento, e a mais tradicional, é a de transferir a chamada que há mais tempo está na fila de espera para o atendente disponível (livre) há mais tempo (INTEL, 2003). Recentemente, houve um avanço no algoritmo de distribuição de chamada e de roteamento quanto à diferenciação do cliente no processo de atendimento. Evolui-se do estático critério de agente presente em grupos de serviços para o dinâmico critério de agentes com a melhor habilidade para atender a chamada, o que permite tratar de forma distinta cada consumidor transferindo a sua chamada para o atendente disponível melhor preparado para responder determinada informação. 
Outro grande avanço no DAC foi a introdução da possibilidade de priorizar clientes não somente conforme a ordem de chegada na fila, mas também conforme sua importância como consumidor, como por exemplo valores de faturamento mensal, ou natureza da empresa (hospitais, segurança pública, etc.), ou conforme o número discado (ERICSSON, 2000; 2005). As chamadas de longa distância que chegam através de número gratuito 0800 podem ter prioridade diferente na fila para chamadas locais através de número gratuito 0800 - o que leva a uma economia de tarifa telefônica pela distribuidora. A seguir Figura 15 explicitando o processo de um DAC com roteamento por habilidade e identificação do cliente.

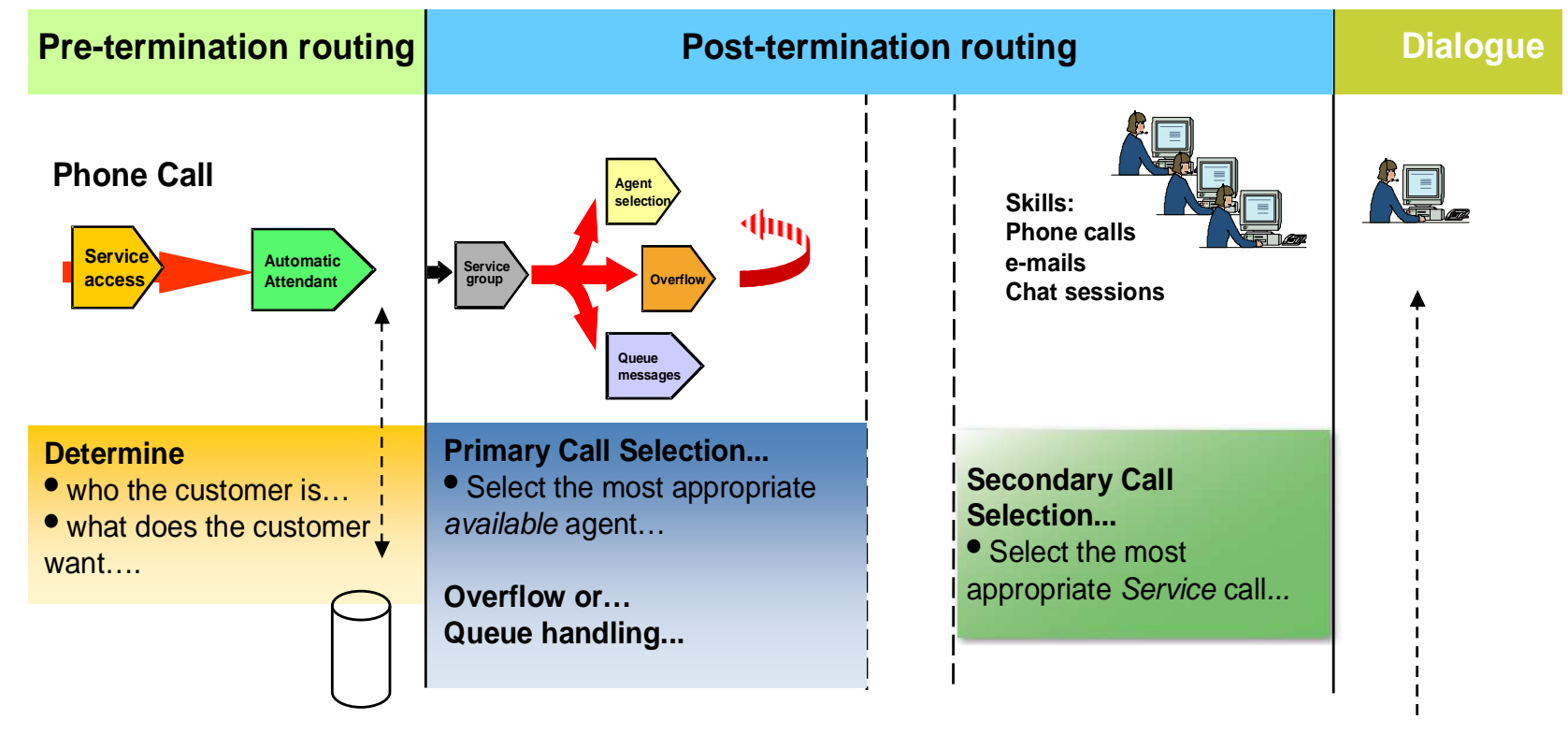

Fonte: ERICSSON, 2005.

Figura 15: Processo de atendimento em um PABX DAC com roteamento por habilidades.

Além disso, citam-se outros recursos avançados de DAC em PABX:

- Gerenciamento em tempo real das chamadas por microcomputador de supervisores;

- Free Seating: os agentes não precisam mais ter uma estação de trabalho fixa. Os agentes têm a flexibilidade de atender as chamadas em qualquer posição de atendimento;

- Agentes Remotos: a atendente pode ter sua estação de trabalho em qualquer local físico;

- Mensagens de espera em fila diferenciadas por serviço ou grupo de atendimento. 
- Regras de roteamento de chamadas dinamicamente alteradas pelo administrador do call center;

- Mudança de prioridade de fila conforme tempo da chamada em espera;

- O encaminhamento condicional de chamadas para atendimento conforme número de agentes disponíveis, número de chamadas na fila e tempo médio de fila;

- Classificação da chamada conforme número chamado (DNIS), número discado (ANI) ou através de Unidade de Resposta Audível (URA);

- Classificação de chamadas feita pelo atendente ao final da ligação;

- Gerenciamento em tempo real das informações do PABX.

- Unidades de Resposta Audível (URA): há duas categorias de URA:

- A primeira categoria é aquela chamada de máquina atendedora ou segmentadora. É a mais usada pelas empresas distribuidoras de energia. Uma máquina segmentadora apenas redireciona e transfere chamadas de clientes conforme a opção escolhida (Para vendas digite 1, para suporte digite 2, etc.);

- A segunda categoria é da URA com consulta aos bancos de dados, que pode desempenhar o mesmo papel da máquina segmentadora, mas ela também é capaz de efetuar consultas a bancos de dados para prover serviços de informações automáticos, tais como saldos. Este tipo de URA permite que os consumidores obtenham informações que desejam sem necessitar serem transferidos aos atendentes humanos. A URA também pode permitir que o cliente se identifique, poupando tempo de todos os envolvidos, e sendo redirecionado conforme essa identificação.

Uma URA com consulta a banco de dados pode coletar um código de identificação que o consumidor digitou (Por favor, digite seu código de consumidor ou Por favor, digite o seu $(P F)$. Uma vez identificado o consumidor, este pode ser transferido em consonância com os critérios definidos no PABX com DAC, como por exemplo, de agente com melhor habilidade ou consumidor preferencial ou prioritário. A URA pode tem também diversos status manualmente manipulados ou conforme agenda do sistema: noturno, diurno, feriado, emergencial, etc. 
Em um possível status emergencial, a URA pode identificar automaticamente o consumidor pelo número de assinante pelo qual o consumidor discou, e relacionar via banco de dados o código de consumidor com o número de assinante telefônico. Caso identifique que o consumidor está sendo alimentado por um circuito primário ou secundário desligado, a URA com consulta a banco de dados pode verbalizar automaticamente uma mensagem com a informação do tempo restante para restauro do seu circuito alimentador, sem transferir para atendimento humano. Mas caso a URA não consiga resolver por completo as dúvidas do consumidor, essa URA pode ter diferentes tipos de integração CTI, transferindo posteriormente para um atendente humano a chamada juntamente com informações de cadastro e de circuito do consumidor.

De acordo com a Ericsson (2000), diversos recursos avançados de URA podem ser citados:

- Criação de menus com múltiplos níveis;

- Coleta de dígitos discados pelo cliente, opcionalmente com dígitos Dual Tone MultiFrequential (DTMF);

- Acesso a banco de dados, tradicionalmente através de Open Data Base Connectivity (ODBC);

- Gravação e reprodução de mensagens, permitindo oferecer na própria URA a facilidade de o próprio cliente deixar mensagem de voz caso não haja agente disponível;

- Reconhecimento Natural de Voz, possibilitando uma interface mais natural para os clientes navegarem, evita menus de atendimento extremamente longos;

- Conversão de texto para voz, que permite que a URA possa ler para o cliente textos armazenados em uma base de dados, de acordo com o exemplo de arquitetura da Figura 16;

- Call Back: uma URA pode agendar rechamadas, conforme opção a ser deixada no menu de navegação. As ligações de rechamada são colocadas em fila de espera virtualmente, e encaminhadas ao agente logo após a ligação ser completada;

- Integração com outras mídias e serviços, como portais de voz pela Internet. 


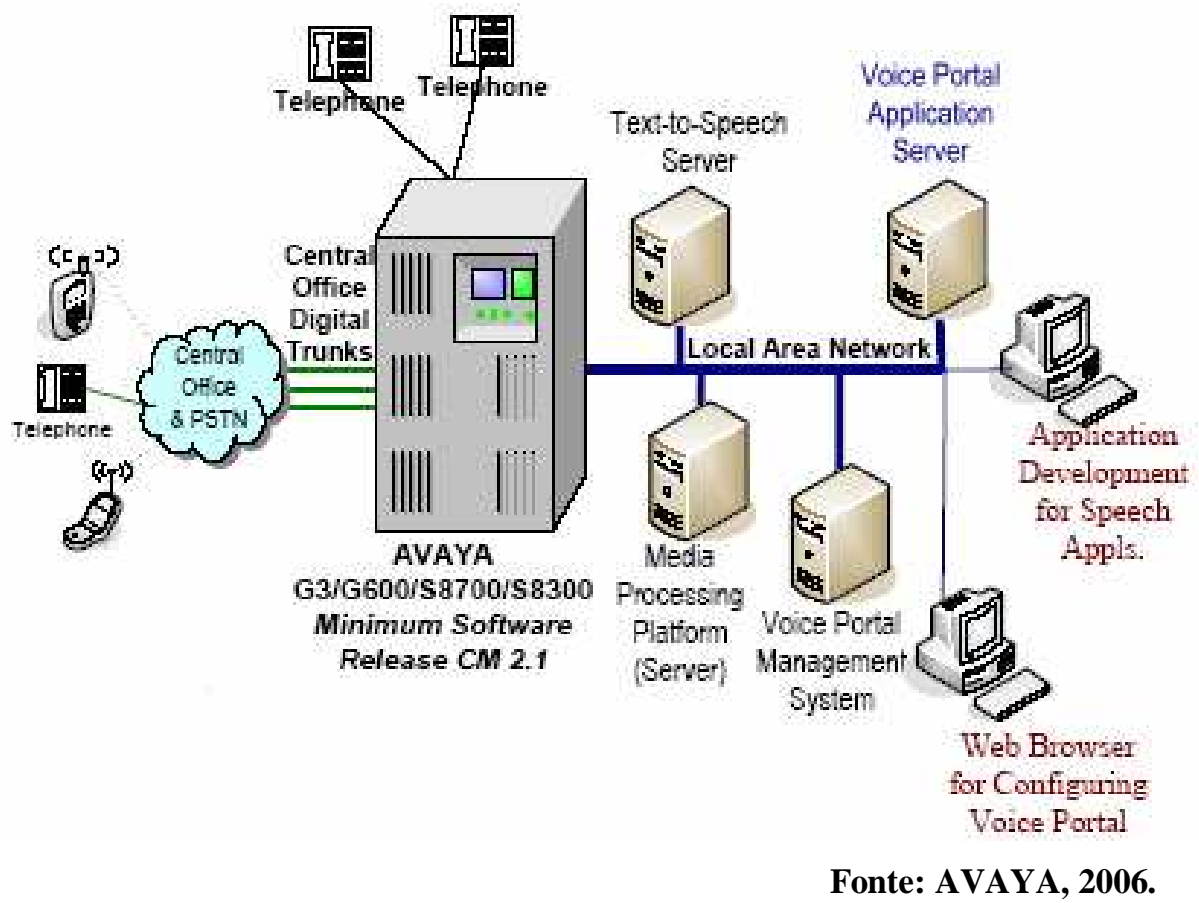

Figura 16: URA integrada com a Internet

- Discadores Automáticos: um computador com a aplicação de discador telefônico se encarrega de discar para um número a partir de uma lista de consumidores interrompidos (campanha), aguardar o tom de discagem, esperar que alguém atenda, e se uma pessoa atender, transfere a chamada para uma mensagem falada (pré-gravada ou dinamicamente alterada) sobre o tempo de restauro do circuito. O discador também tem a capacidade de lidar com diferentes situações de não atendimento: telefone ocupado, ninguém atende, atendimento por secretária eletrônica, modem, atendimento por máquina de fax. A chamada só deve ser transferida para uma mensagem se de fato for atendida. Em caso de não atendimento ou ocupado, o discador faz outra tentativa mais tarde. Há três tipos de discadores automáticos, conforme o algoritmo de discagem: power, preview e predictive dialer, cada um com sua vantagem própria. Normalmente, tem sido mais instalado o power dialer, por sua capacidade e facilidade de instalação (WALTER, 1998).

Entre outros recursos avançados dos discadores automáticos se encontra: conexão com PABX, gerenciamento de múltiplas listas de discagem, possibilidade de um cliente ser chamado através de diversos números cadastrados, múltiplas discagens simultaneamente para diversos clientes, ferramentas de acompanhamento em tempo real das listas e de métricas de campanha de discagem, interfaces abertas de integração (AVAYA, 2003). Na Figura 17, uma foto de um discador de alta capacidade. 


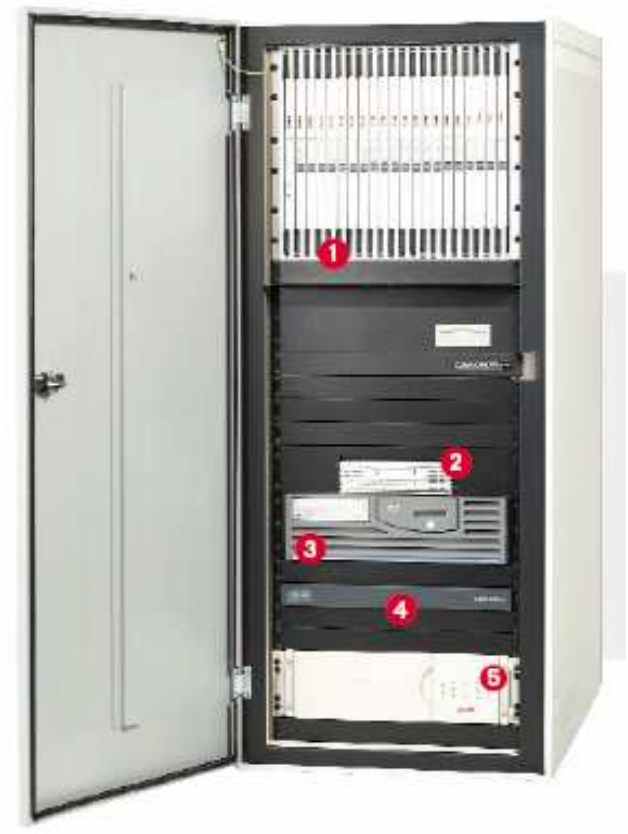

Fonte: AVAYA, 2003.

Figura 17: Discador automático de alta capacidade em formato de gabinete

- Auto resposta de Fax: consiste em o cliente ligar para uma URA e solicitar um fax contendo a informação sobre o restauro de sua energia elétrica. A URA coleta em um banco de dados as informações solicitadas e utiliza um outro computador que controla faxes para enviá-lo automaticamente para o cliente.

- Auto envio de Fax: consiste em enviar automaticamente para os consumidores, de forma ativa, um fax com as informações relativas ao desligamento emergencial de energia, incluindo o tempo de restauro.

- Auto resposta de e-mails: os e-mails recebidos pelo contact center podem ser redirecionados para um sistema de inteligência artificial responder. Com a aplicação de resposta automática de e-mails as solicitações dos consumidores podem ser respondidas imediatamente, com informações precisas, minimizando a necessidade do contato mais custoso de agentes reais. Sistemas como esses são baseados em máquinas virtuais que analisam o conteúdo das mensagens através de palavras-chave contidas no campo "assunto" ou dentro do texto do e-mail para encontrar, dentro de uma Base de Conhecimento, dados para uma proposta de resposta mais adequada. Se a resposta proposta pela máquina virtual satisfizer determinado critério de confiança, a máquina virtual responderá diretamente ao cliente. Caso a confiança não seja adequada, o email é redirecionado para que um agente humano possa editar a resposta proposta pela máquina virtual antes da resposta definitiva. 
Por exemplo: se no campo Assunto estiver escrito "Energia desligada" e/ou "Problema na Luz”, um sistema integrado pode acessar dados em tempo real sobre a situação do circuito elétrico primário do grupo o qual pertence o consumidor, e responder automaticamente com uma mensagem padrão introdutória e adicionalmente um texto com o tempo previsto de retorno. As máquinas mais avançadas podem analisar até a sintaxe de frases completas. Como requerimento adicional, além da aplicação de auto resposta de e-mail, é também necessário um Servidor de E-mails com uma caixa postal e endereço divulgado de forma dedicada ao serviço (ERICSSON, 2004b).

Outros recursos avançados deste sistema, de acordo com a Siemens (2001):

- Personalização de cabeçalhos e rodapé para cada e-mail de resposta;

- Quando se responde um e-mail, é anexado automaticamente o e-mail que gerou a resposta;

- Inserir outros anexos no e-mail;

- Suporte a corretor multi-idioma para correção do texto do e-mail antes de envio;

- Controle dos e-mails conforme as mesmas regras de DAC do PABX.

- Auto resposta de SMS: o mecanismo de auto resposta de SMS é semelhante ao da auto resposta de e-mails. Contudo, uma máquina virtual de SMS pode responder a uma mensagem de SMS de um consumidor enviando uma mensagem SMS de volta ao seu originador, ou responder a uma chamada de voz enviando uma mensagem SMS para um destino externo. Dois tipos de conectividades são possíveis: a) certa quantidade (dependendo do tráfego esperado) de Modem GSM ou CDMA conectadas a aplicação de SMS, pois é através deste modem que as mensagens de SMS serão recebidas e enviadas ou; b) um SMS Center, o qual habilitará o contact center enviar e receber vasta quantidade de SMS com conexão direta com o gateway da concessionária de telefonia móvel de telefonia que transporta o SMS (ERICSSON, 2005). 
- Formulários na Web: praticamente toda distribuidora possui website na Internet. De uma maneira geral, um formulário na Web por ser definido como um portal que provê aos usuários da Internet um meio de acessar o conteúdo de uma empresa via textos. Desenvolver formulários na Web, de modo a prover serviços aos clientes das empresas, é uma tendência crescente na indústria da comunicação. Tecnologias já consolidadas como HTML, HTTP, e IP combinadas com novas linguagens como o VoiceXML e XML, além de interfaces padrões como o WSDL, SOAP, e UDDI estão acelerando esse movimento (INTEL, 2004). Exemplos de formulários da Web podem ser vistos nas figuras do item 3.1.

- Auto envio de SMS: consiste em enviar automaticamente para os consumidores, de forma ativa, uma mensagem de SMS para seus terminais celulares, com as informações relativas ao desligamento emergencial de energia, incluindo o tempo de restauro. Considera-se que o SMS apresenta três fatores que reforçam o valor da informação para os usuários de celulares: personalização, rapidez e mobilidade. A aplicação desses três fatores pelas distribuidoras permitirá que aumentem a sua atratividade para os usuários de celulares. Além disso, campanhas de SMS podem ser criadas, de forma a divulgar, por exemplo, esse novo canal de informação. É possível, com esta aplicação, que o consumidor registre-se no website da distribuidora para receber mensagens SMS pelo seu celular pessoal (CONNEX, 2006). A partir de então, nos futuros desligamentos, o sistema SCADA da rede elétrica enviará comandos para o sistema de auto-envio de SMS para que este determinado consumidor receba certas mensagens de SMS referente o circuito elétrico primário em questão (KLINKMAN, 2005). A Figura 18 demonstra um exemplo desse serviço.

- $\quad$ Auto envio de E-mail: sistema semelhante ao auto-envio de SMS. Consiste em enviar automaticamente para os consumidores, de forma ativa, uma mensagem de e-mail para seus computadores ou terminais móveis, com as informações relativas ao desligamento emergencial de energia, incluindo o tempo de restauro. 


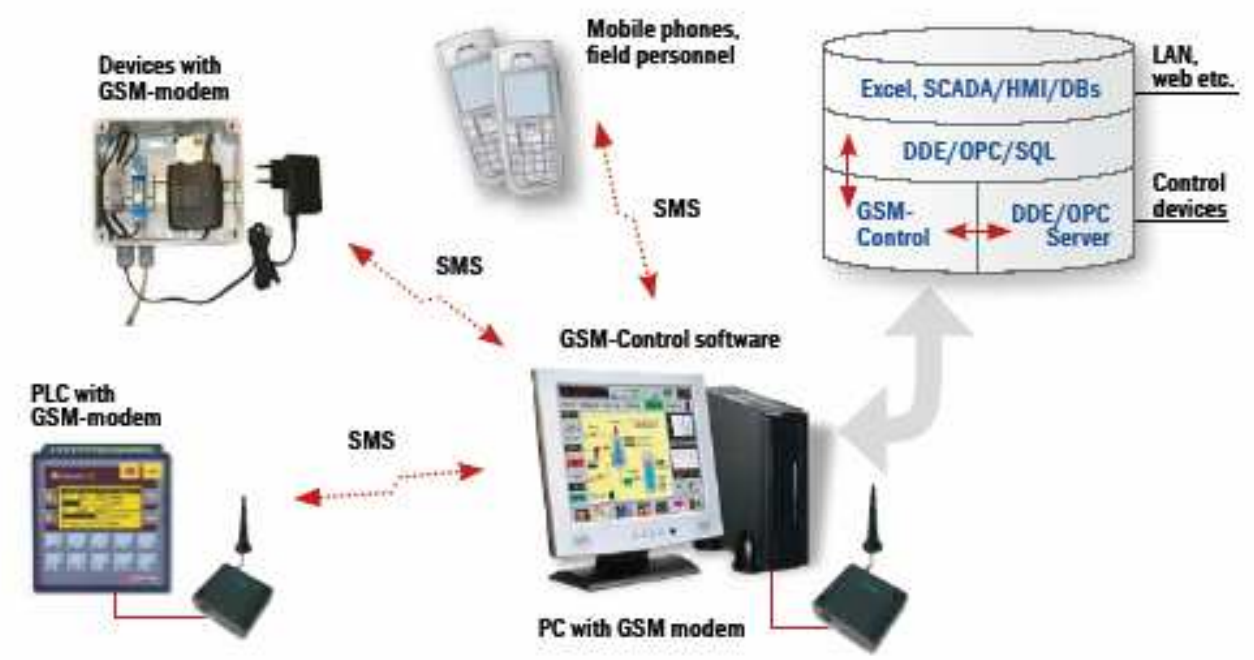

Fonte: Klinkman, 2005.

Figura 18: Automação de recebimento de SMS a partir de plataformas SCADA.

- Web Chat: consiste em permitir a um consumidor que navegar na Internet iniciar uma sessão de conversa via texto em tempo real com um atendente. O Web Chat é o mecanismo utilizado em salas de bate-papo de websites, porém no caso de um contact center, o Chat é um meio de contato entre clientes e atendentes, e é gerenciado tendo em vista a qualidade e rapidez do atendimento. $\mathrm{O}$ atendente pode estar conectado com vários clientes ao mesmo tempo, e o conteúdo da conversa que este teve com o cliente pode ser enviado por e-mail se o cliente desejar. Há sistemas que fornecem roteiros para as respostas às questões do cliente, de modo que o agente envie respostas prédigitadas aos clientes, garantindo padronização e rapidez. Algumas respostas inclusive podem ser automáticas ou sugeridas por uma base de conhecimento, desde que a pergunta seja simples o suficiente (ERICSSON, 2005), conforme indica a Figura 19. 


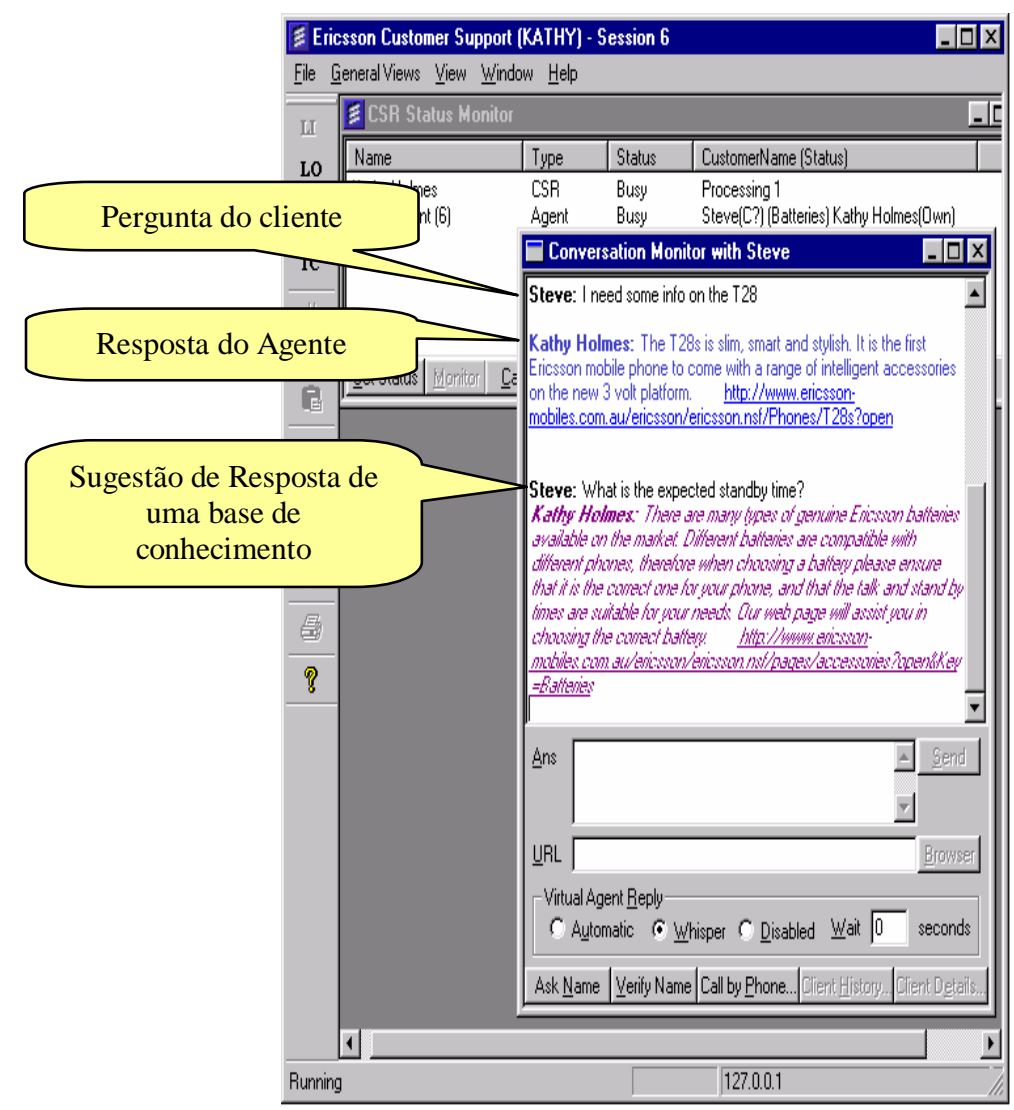

Fonte: ERICSSON, 2005.

Figura 19: Exemplo de Web Chat entre consumidor e atendente, com sugestão de resposta por uma base de conhecimento.

- $\quad$ Agentes Virtuais: é uma aplicação que implementa o serviço de auto-atendimento na página da Internet das empresas, ou em máquinas instaladas em locais públicos de grande circulação. Permitem que o contact center responda automaticamente às solicitações do cliente de forma rápida e precisa, usando uma base de conhecimento de respostas, minimizando a interação de um agente humano. Os Agentes Virtuais integram-se basicamente a Internet, mas permitem também que sejam desenvolvidas aplicações de Agentes Virtuais para quiosques em supermercados, farmácias, shopping center, ou mesmo para terminais de televisão, e principalmente para celulares (Internet Móvel). O Agente Virtual não se limita a fornecer respostas de texto, ele possui a capacidade de enviar mensagens de voz ou mesmo multimídia, enriquecendo assim a experiência on-line dos clientes. O Agente Virtual pode assumir várias personalidades para poder projetar a imagem mais apropriada da empresa. Pode-se ainda configurar para que o cliente digite uma senha e identifique-se para utilizar o serviço do Agente Virtual. 
Resolvendo a maior parte das solicitações rotineiras, os agentes reais ficam livres para fornecer mais serviços de valor agregado aos clientes diferenciados. Mas clientes que solicitam ou necessitam de atendimento pessoal podem ser previamente atendidos por um Agente Virtual, e depois direcionados para um agente real habilitado. O agente humano que recebe este contato redirecionado recebe também o histórico das interações do cliente com o Agente Virtual, podendo ver que perguntas já foram feitas e respectivas respostas dadas pelo Agente Virtual (CODEBABY, 2006).

A aplicação Agente Virtual pode ser integrada facilmente a qualquer website e implementada com a tecnologia Java (ver Figura 20). Esta aplicação pode ficar como um frame (divisão) na página Web, ou pode ficar em uma janela separada.

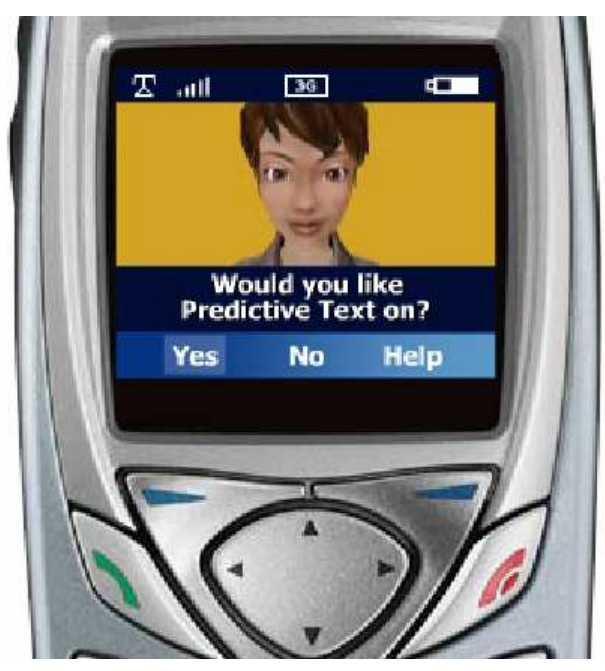

Fonte: CodeBaby, 2006.

Figura 20: Demonstração de Agente Virtual em terminal celular sobre a Internet Móvel.

- $\quad$ Rechamada agendada pela Web (Web call back): no website da empresa o cliente seleciona um link com um texto do tipo "ligue para mim"; ao clicar neste link, surge uma página na qual o cliente digita seu nome e um número de telefone para contato e a hora em que quer ser contatado, e também pode adiantar qual o assunto que quer tratar. Na hora marcada, o cliente recebe a ligação de um atendente da empresa - ver Figura 21. Os softwares que implementam esta facilidade devem automatizar os processos de coletar os dados do cliente, iniciar a ligação na hora marcada e transferir a chamada a um atendente, informando na tela do atendente os dados do cliente (ERICSSON, 2000; 2005). 


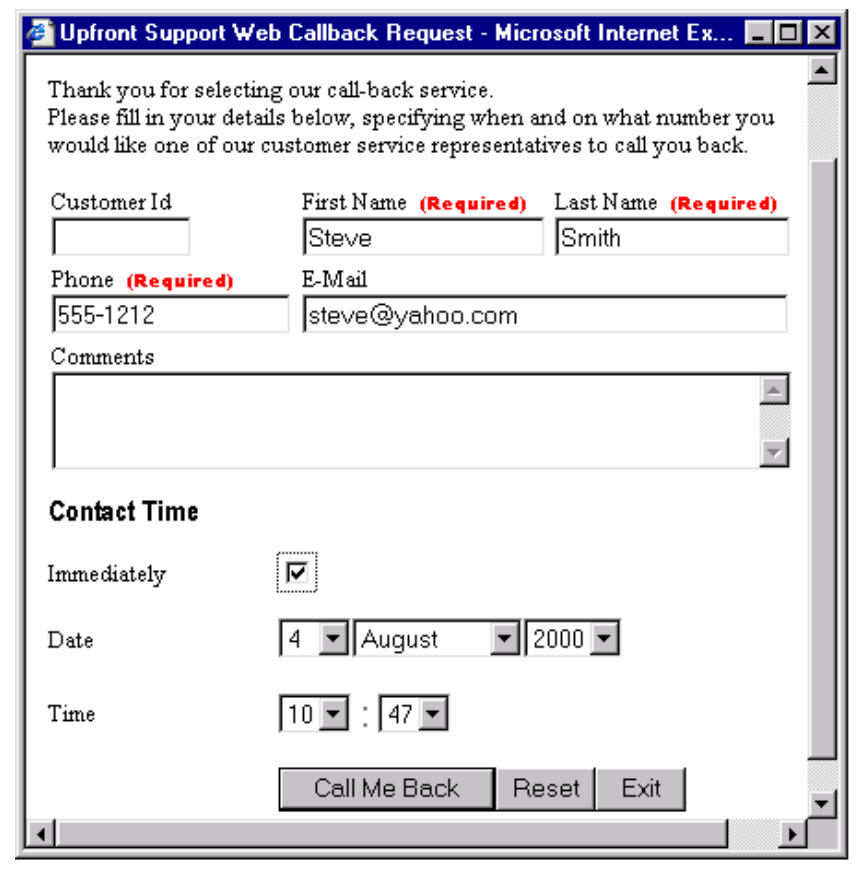

Fonte: ERICSSON, 2005.

Figura 21: Exemplo de página em website para requisição de Rechamada na Web.

- Interceptação de chamadas telefônicas: o serviço autorizado de interceptação de chamadas telefônicas é amparado pela Lei Federal № 9.296 de 24 de julho de 1996 e pela Resolução da ANATEL № 252 de 20 de dezembro de 2000. A interceptação é autorizada mediante casos excepcionais citados no artigo 56 da Resolução № 252/2000, ou seja, nas condições de: código de acesso mudado, terminal fora de serviço, código de seleção de prestadora incorreto, código nacional incorreto, e demanda excepcional na Rede de Telecomunicações. A interceptação de chamadas fora dessas condições depende de autorização especial pela ANATEL.

Segundo a ANATEL (2000), o congestionamento dos meios de acesso a certo assinante do Serviço Telefônico Fixo Comutado (STFC) pode ser previamente monitorado, de forma que as chamadas excedentes em direção a este assinante serão automaticamente redirecionadas para um Sistema de Mensagens Gravadas. Ou seja, ao invés de a concessionária local do STFC sinalizar rede inacessível ou ocupada nos casos de congestionamento no acesso a determinado assinante, o consumidor de energia elétrica receberá, de acordo com a Resolução № 252/2000 da ANATEL, um sinal de encaminhamento para Sistema de Interceptação de Chamadas, sinal constituído por uma frase musical (duração 3 segundos) e uma mensagem inicial com a seguinte fraseologia: "Sua chamada está sendo encaminhada para a caixa de mensagens e estará sujeita a cobrança após o sinal". 
Após a mensagem inicial, o usuário é redirecionado para o Sistema de Mensagens Gravadas, com mensagem construída de modo a fornecer todas as informações necessárias para esclarecer o usuário, sobre o que se passa com a sua chamada, ou auxiliá-lo para a finalização de sua chamada. Quando da indisponibilidade ou do esgotamento da capacidade do atendimento do Sistema de Interceptação, os usuários do STFC devem ser liberados e enviados a eles o sinal de Rede Inacessível ou Rede Ocupada.

De acordo com Leite (2005), o método de interceptação que apresenta maior eficiência em relação ao volume e à qualidade de dados interceptados é aquele executado diretamente na central telefônica digital da concessionária do STFC. Todas as funções utilizam o próprio hardware implementado na central, sem a necessidade de dispositivos externos. Todavia, em 29 de Janeiro de 2003 a ANATEL publicou a Resolução № 32 que reconheceu a dificuldade que certas concessionárias de telefonia tem em implementar essas funções de interceptação de chamadas, e está reavaliando um novo regulamento.

\subsection{OS CENTROS DE ATENDIMENTO EM REDE}

Foi dedicado um item à parte para esta avançada tecnologia, devido a sua importância como solução prática que vai de encontro aos objetivos desta pesquisa. Atualmente é possível que as Centrais de Teleatendimento individuais sejam interligadas em rede e que funcionem juntas como um único centro virtual. Quando o volume de chamadas telefônicas fica muito grande em uma Central de Teleatendimento, e os alarmes de Tempo Médio de Espera (TME) começam a disparar, as configurações de limite definidas permitem que as chamadas excedentes sejam desviadas para uma outra Central de Teleatendimento. Deste modo, é possível transformar diversas centrais de teleatendimento isoladas em um único contact center virtual, reduzindo os custos e aumentando a eficiência e rapidez de atendimento (ERICSSON, 2005). 
Para entender melhor esta facilidade, é considerado o exemplo abaixo:

- A distribuidora XYZ possui sua área de concessão na região $\mathrm{A}$, e por sua vez a distribuidora XPTO tem sua área de concessão na região B. Ambas as empresas tem centrais de Teleatendimento independentes, que atendem somente a sua própria região de concessão;

- A distribuidora XYZ enfrenta os seguintes problemas:

- Nos Dias Críticos, ocorrem horas de alto volume de chamadas telefônicas, e conseqüentemente muita perda de chamadas na sua central de teleatendimento, enquanto que a central de teleatendimento da distribuidora XPTO trabalha com capacidade ociosa, pois os Dias Críticos nas regiões de concessão não são coincidentes;

- A empresa XYZ gostaria de transferir parte das chamadas excedentes para serem atendidas pela empresa XPTO, mas de forma integrada e unificada, sem perder a independência e o gerenciamento, todavia dando também condições para que a empresa XPTO tenha acesso às informações necessárias ao atendimento do consumidor da empresa XYZ;

- Ao transferir uma chamada para atendimento pela empresa XPTO, caso um dos atendentes da empresa XPTO necessite pedir ajuda a um especialista da empresa XYZ, deverá possuir meios de fazê-lo sem transferir novamente a chamada ou pedir ao cliente para ligar de novo mais tarde;

- A empresa XYZ usa um sistema de Front Office para acessar e atualizar dados, e gostaria de integrá-lo ao atendimento da empresa XPTO;

A solução, nesse exemplo, envolve primordialmente um espírito de colaboração e confiança mútua. Envolve também, em termos da tecnologia de informação:

- Estabelecer uma conexão de dados privativa via Internet Protocol (IP) conectando as duas redes de computadores das centrais de teleatendimento;

- Estabelecer uma conexão de voz privativa via Integrated Service Digital Network (ISDN) conectando os dois PABX de cada central de teleatendimento;

- Em cada localidade, implantar um computador servidor de Computer Telephony Integration (CTI) conectado ao PABX local e a rede de computadores local, de forma a possibilitar controle de chamadas e integração;

- Os servidores CTI de ambas as localidades devem comunicar-se entre si através da rede privativa IP; 
- Os clientes de cada região podem continuar ligando para as respectivas centrais de teleatendimento de sua distribuidora local, mas agora o sistema permite transbordar automaticamente chamadas de forma transparente para o cliente, através da rede privativa ISDN. Para tomar a decisão de transbordo, o servidor CTI local compara dados de desempenho de cada grupo de atendimento, levando em conta o Tempo Estimado de Espera (TME), número de chamadas em fila e quantidade de atendentes disponíveis em cada local;

- O gerenciamento em tempo real da central de teleatendimento é descentralizado. Os gerentes e supervisores da central de teleatendimento da empresa XYZ poderão acompanhar somente desempenho em tempo real das suas próprias chamadas;

- Os relatórios históricos de toda a central de teleatendimento virtual também são gerados de forma descentralizada, ou centralizada e consolidada, conforme opção. Ou seja, não é necessário gerar relatórios de cada local separadamente e depois comparálos: pode-se gerar um único relatório histórico incluindo desempenho de atendentes dos dois locais;

- Se um agente da região B estiver atendendo uma chamada e necessitar de ajuda especializada da região A, este pode localizar em tempo real quais são os especialistas com competência para ajudá-lo, através da rede privativa de dados via IP (usando, por exemplo, aplicações de mensagens instantâneas tipo Session Initiation Protocol (SIP), ou mesmo o Windows Live Messenger ${ }^{24}$ ) e através das funcionalidades avançadas de uma rede privativa de voz ISDN;

- As interfaces dos servidores CTI permitirão integrá-los ao sistema Front Office de cada empresa. Os agentes recebem os dados do cliente na tela, simultaneamente às chamadas, e ao transferir a chamada, mesmo entre cidades diferentes, a tela também é transferida.

Foi descrita a situação de duas centrais de teleatendimento operando em rede, mas é possível ampliar essa rede para diversos nós. É admissível integrar até dezenas de localidades. Na Figura 22 consta um diagrama típico de implantação da solução com dois locais. É importante notar em que ambos os locais há uma infra-estrutura própria para atendimento.

\footnotetext{
${ }^{24}$ É o nome para a nova geração do "MSN Messenger". O "MSN Messenger" é um programa de mensagens instantâneas criado pela Microsoft Corporation. O programa permite que um usuário da Internet se comunique por voz, vídeo ou texto com outro que tenha o mesmo programa em tempo real, podendo ter uma lista de contatos "virtuais" e acompanhar quando eles entram e saem da rede.
} 


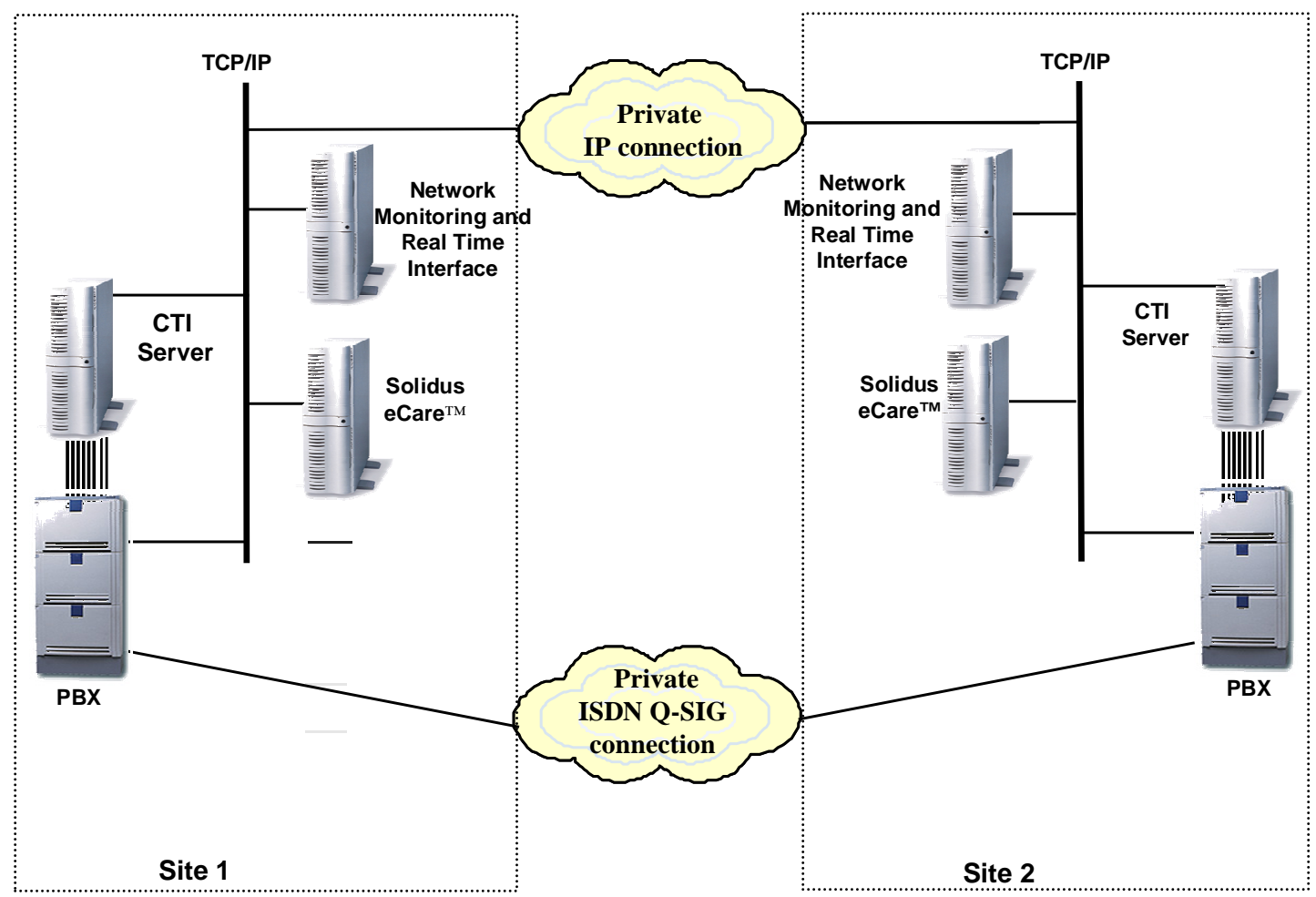

Fonte: ERICSSON, 2005.

Figura 22: Exemplo de duas Centrais de Teleatendimento Operando em Rede. 


\section{O CONTEXTO DA QUALIDADE DE SERVIÇO}

\subsection{AS MÉTRICAS DE QUALIDADE DE ATENDIMENTO SEGUNDO A ANEEL}

A ANEEL definiu, através da Resolução Normativa № 57 de 2004, que a Qualidade do Atendimento Telefônico é o conjunto de atributos dos serviços proporcionados pela concessionária objetivando satisfazer, com adequado nível de presteza e cortesia, as necessidades dos solicitantes, segundo determinados níveis de eficiência e eficácia.

A ANEEL, por essa mesma resolução, estabeleceu os níveis de eficiência necessários, que são as métricas de atendimento telefônico. Essas métricas não são válidas para os Dias Críticos, mas devem ser adotadas pelas distribuidoras como referência ou meta de qualidade de serviço.

Em sistemas telefônicos, a maneira tradicional de definir Nível de Serviço é olhando para a fração de chamadas que excedem a certo tempo de espera para serem respondidas. E dessa visão nasce o conceito de Acceptable Waiting Time (AWT), ou Tempo Médio de Espera (TME). O "padrão da indústria" é que $80 \%$ das chamadas devem ter resposta em até 20 segundos, mas outros números são possíveis (KOOLE, 2006).

O Artigo 11 da Resolução № 57 de 2004 da ANEEL fixa metas anuais do Índice de Nível de Serviço Básico (INB) para cada grupo de concessionárias, conforme Tabela 3:

Tabela 3: Metas Anuais de Índice de Nível de Serviço da ANEEL.

\begin{tabular}{|c|c|c|c|c|c|c|c|}
\hline A partir do ano & $\mathbf{2 0 0 5}$ & $\mathbf{2 0 0 6}$ & $\mathbf{2 0 0 7}$ & $\mathbf{2 0 0 8}$ & $\mathbf{2 0 0 9}$ & $\mathbf{2 0 1 0}$ & $\mathbf{2 0 1 1}$ \\
\hline Grupo I & $80 \%$ & $85 \%$ & $90 \%$ & $95 \%$ & $95 \%$ & $95 \%$ & $95 \%$ \\
\hline Grupo II & $77 \%$ & $80 \%$ & $85 \%$ & $90 \%$ & $95 \%$ & $95 \%$ & $95 \%$ \\
\hline Grupo III & $77 \%$ & $80 \%$ & $85 \%$ & $90 \%$ & $95 \%$ & $95 \%$ & $95 \%$ \\
\hline Grupo IV & $70 \%$ & $74 \%$ & $77 \%$ & $80 \%$ & $85 \%$ & $90 \%$ & $95 \%$ \\
\hline
\end{tabular}

Fonte: ANEEL. Resolução Normativa N 57/2004.

O INB representa a porcentagem de Chamadas Atendidas (CA) em até 30 segundos.

A porcentagem de chamadas que são atendidas antes de TME é geralmente chamada de Telephone Service Factor (TSF), ou Fator de Serviço. O TSF é comumente usado como métrica em centros de teleatendimento, mas é mais interessante prestar atenção nas diferentes interpretações desse número, até do ponto de vista do consumidor. Segundo Koole (2006), se for considerado o tradicional "padrão da indústria", deve-se assumir que $80 \%$ dos consumidores receberão bons serviços, e $20 \%$ maus serviços. 
Outro modo de definir Nível de Serviço é pelo número de Chamadas Abandonadas $(\mathrm{CAb})$. Consumidores abandonam as Chamadas em Espera (CE) porque estes não têm paciência de esperar em fila por uma posição de atendimento disponível. Consumidores geralmente tem uma paciência limitada a um minuto, e a esse tempo denomina-se Tempo Médio de Abandono (TMAb). É claro que a taxa de abandono é fortemente relacionada com o Tempo Médio de Espera (TME), e por isso geralmente os gestores dos centros de teleatendimento escolhem parâmetros de forma a diminuir o Índice de Abandono (IAb). Porcentagens entre 3 ou 5\% são consideradas aceitáveis, de acordo com conclusões de Koole (2006).

O Artigo 11 da Resolução № 57 de 2004 da ANEEL fixa metas anuais do Índice de Abandono (IAb) para cada grupo de concessionárias, conforme Tabela 4:

Tabela 4: Metas Anuais de Índice de Abandono da ANEEL.

\begin{tabular}{|c|c|c|c|c|c|c|c|}
\hline A partir do ano & $\mathbf{2 0 0 5}$ & $\mathbf{2 0 0 6}$ & $\mathbf{2 0 0 7}$ & $\mathbf{2 0 0 8}$ & $\mathbf{2 0 0 9}$ & $\mathbf{2 0 1 0}$ & $\mathbf{2 0 1 1}$ \\
\hline Grupo I & $15 \%$ & $10 \%$ & $7 \%$ & $4 \%$ & $4 \%$ & $4 \%$ & $4 \%$ \\
\hline Grupo II & $17 \%$ & $12 \%$ & $8 \%$ & $6 \%$ & $4 \%$ & $4 \%$ & $4 \%$ \\
\hline Grupo III & $17 \%$ & $15 \%$ & $12 \%$ & $8 \%$ & $6 \%$ & $4 \%$ & $4 \%$ \\
\hline Grupo IV & $20 \%$ & $18 \%$ & $15 \%$ & $12 \%$ & $8 \%$ & $6 \%$ & $4 \%$ \\
\hline
\end{tabular}

Fonte: ANEEL. Resolução Normativa N ${ }^{0}$ 57/2004.

Um centro de teleatendimento pode eliminar toda a possibilidade de congestionamento alocando número de linhas de acesso igual ao número de Chamadas Oferecidas (COf) simultâneas. Óbvio que este tipo de prática não é possível nas centrais de teleatendimento de concessionárias de energia elétrica, embora seja possível em serviços específicos de natureza privada (exemplo, agendamento de consultas médicas em clínicas). Dessa forma, sempre haverá a possibilidade de sinal de ocupado ao consumidor de energia elétrica que chama em Dias Críticos. Essa possibilidade chama-se Índice de Chamadas Ocupadas (ICO). Koole (2006) indica que porcentagens entre 5 ou 10\% são consideradas aceitáveis.

O Artigo 11 da Resolução № 57 de 2004 da ANEEL fixa metas anuais do Índice de Chamadas Ocupadas (ICO) para cada grupo de concessionárias, conforme Tabela 5: 
Tabela 5: Metas Anuais de Índice de Chamadas Ocupadas da ANEEL.

\begin{tabular}{|c|c|c|c|c|c|c|c|}
\hline A partir do ano & $\mathbf{2 0 0 5}$ & $\mathbf{2 0 0 6}$ & $\mathbf{2 0 0 7}$ & $\mathbf{2 0 0 8}$ & $\mathbf{2 0 0 9}$ & $\mathbf{2 0 1 0}$ & $\mathbf{2 0 1 1}$ \\
\hline Grupo I & $20 \%$ & $15 \%$ & $7 \%$ & $4 \%$ & $4 \%$ & $4 \%$ & $4 \%$ \\
\hline Grupo II & $25 \%$ & $18 \%$ & $12 \%$ & $7 \%$ & $4 \%$ & $4 \%$ & $4 \%$ \\
\hline Grupo III & $28 \%$ & $22 \%$ & $18 \%$ & $12 \%$ & $7 \%$ & $4 \%$ & $4 \%$ \\
\hline Grupo IV & $32 \%$ & $28 \%$ & $24 \%$ & $18 \%$ & $12 \%$ & $7 \%$ & $4 \%$ \\
\hline
\end{tabular}

Fonte: ANEEL. Resolução Normativa No 57/2004.

\subsection{CLASSIFICAÇÃO DOS SERVIÇOS DE ATENDIMENTO}

A despeito das métricas da ANEEL presentes na Resolução № 57/2004, é proposta deste trabalho tratar do tema da qualidade de serviço de atendimento mais sob a ótica do consumidor de energia elétrica e das comunicações multimídia, e menos sob a ótica dos sistemas telefônicos, e daí surgem as seguintes possibilidades de classificação desses serviços nas distribuidoras:

a) Conforme a Classe do Serviço: É possível qualificar os serviços de atendimento segmentando-os conforme a classe do serviço prestado versus a interação humana no processo de comunicação. Essa classificação é sugerida pela Ericsson (2005). Quanto maior a interação humana (Live Service) no processo de atendimento, maior será o custo do serviço, mas será maior também a classe (qualidade) do serviço (Serviço Premium). Quanto menor a interação humana (Auto Service), mais barato será prestar o serviço de atendimento, mas é também menor a classe do serviço (Serviço Básico). $\mathrm{O}$ ponto de equilíbrio está em mesclar o atendimento humano com o atendimento automático (Auto Live), tornando disponíveis as diversas mídias de contato para escolha e decisão do cliente. O Gráfico 3 demonstra essa classificação;

b) Conforme o Público Alvo consumidor: Os serviços de atendimento podem ser classificados conforme o público alvo consumidor: Residencial, Comercial, Industrial ou Outros (iluminação pública, autarquias, etc.), ou para todos esses (público em Geral ${ }^{25}$. O público alvo também pode ser classificado como sendo Prestador ou não de Serviço Essencial, pois aos Prestadores de Serviços Essenciais deve-se dar atenção especial;

\footnotetext{
${ }^{25}$ O público alvo consumidor ainda poderia ser classificado como de área Rural ou Urbana, além de consumidor com Ligação Fixa ou Temporária. Adicionalmente, o público alvo pode ser classificado conforme sua classe de tensão: Grupo A (acima de 2,3 KV), subdivididos ainda em A1, A2, A3 e A4; Grupo B (abaixo de 2,3 KV), de acordo com Decreto № 62.724 de 17/05/1968 e outros regulamentos pertinentes ao assunto. Todavia, nenhumas dessas classificações serão adotadas nesta dissertação.
} 


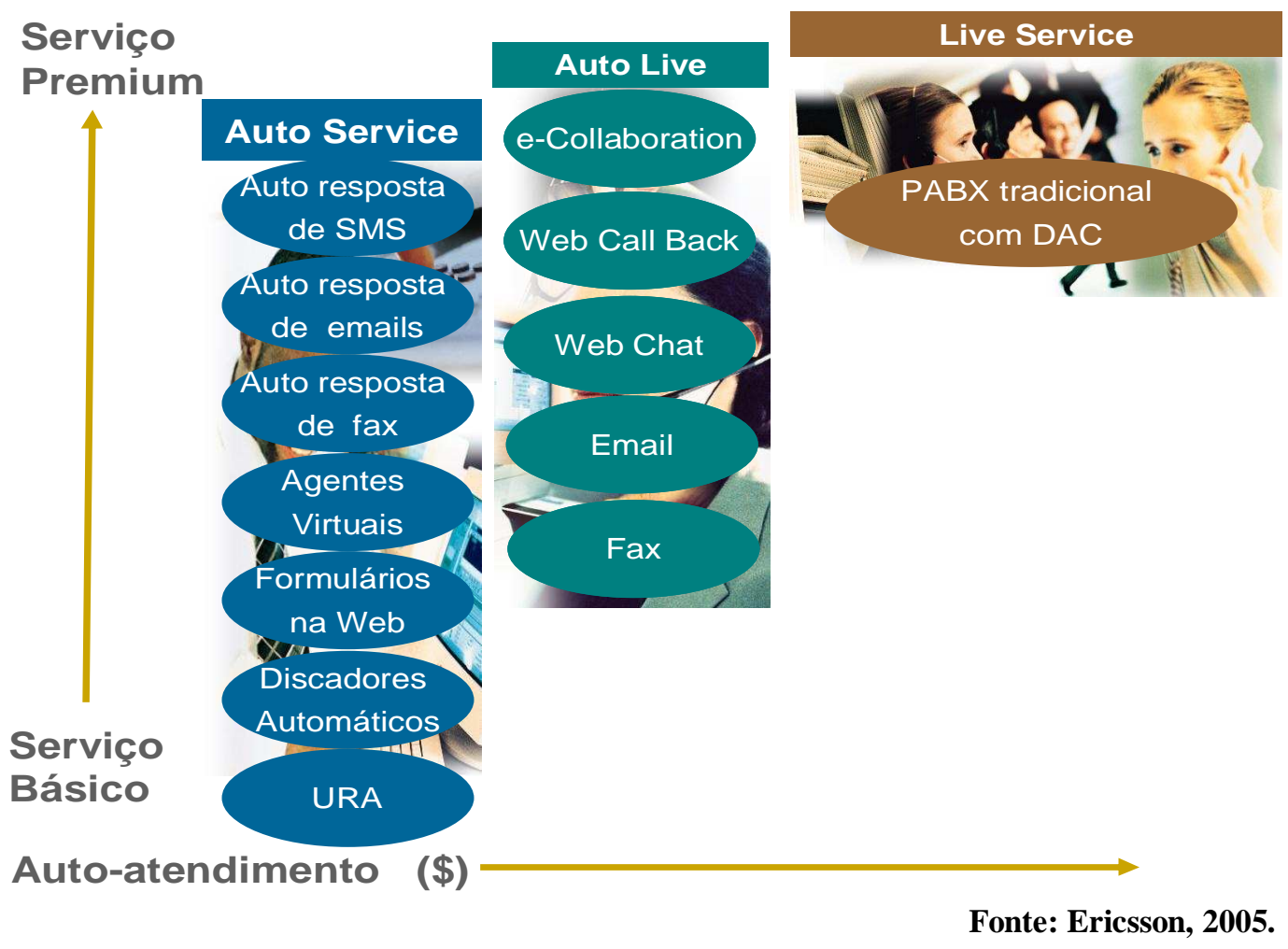

Gráfico 3: Qualificação de aplicações multimídia em centros de atendimento, conforme interação humana versus classe de serviço.

c) Quanto à Penetração: são de Ampla ou Restrita penetração os serviços de atendimento ao consumidor; geralmente para o público empresarial são de restrita penetração, pois exige destes maiores recursos tecnológicos e fonte local de energia ininterrupta para estes recursos.

d) Conforme o Uso: de acordo com o seu desempenho de papel ativo ou receptivo, ou seja:

- Uso receptivo: provê meios para que os consumidores acessem informações do sistema e para que estes reportem mais informações, de forma que esses dados sejam imputados no sistema de gerência de informações;

- Uso ativo: provê meios de informar e atingir os consumidores antes que estes procurem os meios receptivos de comunicação; 


\subsection{QUALIDADE DE SERVIÇOS NA INFRA-ESTRUTURA DE COMUNICAÇÃO.}

Até pouco tempo, as redes de comunicação suportavam uma única aplicação. As redes de voz suportavam somente ligações telefônicas, por exemplo. O mesmo conceito para as redes de dados ou de TV, independente dos meios de transmissão (cabo, rádio, satélite, fibra ótica). Mas hoje se depara com o conceito de Redes Integradas, em que uma mesma rede serve simultaneamente de suporte para todos os serviços ou tecnologias de comunicação.

$\mathrm{O}$ advento de redes integradas de comunicação em alta velocidade abre espaço para as tecnologias multimídia. Mas essas novas tecnologias impõem fortes requisitos sobre o desempenho e qualidade de serviços das Redes Integradas, já que são serviços de tempo real e geralmente são também interativas.

Segundo Stanton, Barra e Bastos (1996) é importante analisar nessas redes integradas a:

a) Implantação de arquitetura de sistemas que permitam a segregação do tráfego de comunicação de determinado serviço;

b) Conexão com legados que garanta um impacto reduzido a ser produzido pelos novos serviços multimídia, de modo a não afetar a qualidade das comunicações préexistentes.

\subsubsection{Arquitetura de Sistemas.}

Além da correta escolha dos serviços de atendimento, é preciso considerar uma série de outros fatores coadjuvantes nas práticas de projeto de um sistema de comunicação multimídia. Os desafios englobam questões como diversidades de interfaces, protocolos e linguagem distintos, compatibilidade entre equipamentos novos e existentes. Esse universo de problemas intitula-se arquitetura de sistemas, conforme é descrito a seguir:

a) O primeiro desafio que se apresenta para um projeto de sistema é a existência de diversas topologias de rede de comunicação possíveis. Um projetista deve considerar todas as possibilidades de topologia, avaliando: custo, performance, segurança, escalabilidade, crescimento tecnológico, Total Cost of Ownership (TCO), Return Over Investment (ROI), gerenciamento, suporte técnico nacional e obsolescência. Assim sendo, a estrutura topológica é uma das primeiras fases do projeto. Inicia-se o projeto a partir de considerações de onde localizar os componentes e como interligá-los, 
sujeitando-se às restrições de conectividade. O resultado dessa etapa é uma matriz de conectividade, incluindo as locações ótimas para os equipamentos;

b) Após essa etapa, o problema seguinte enfrentado pelo projetista de redes é fazer com que cada componente se conecte a todos os outros com desempenho razoável. Por exemplo, conexões com pontos remotos podem apresentar problemas de lentidão na transmissão;

c) Também é importante, quando se projeta um sistema, prever a possibilidade de termos apenas uma pequena parte instalada inicialmente (que atenda à demanda do tráfego prioritária), seguida de expansão em etapas sucessivas até a máxima capacidade do sistema (atendendo uma demanda de tráfego reprimida);

d) Passando estas fases, há a questão da confiabilidade a resolver. Em função do nível de confiabilidade definido, projeta-se o nível de redundância necessário para as instalações do sistema;

e) Por fim, o local de implantação do projeto deve atender certas necessidades, como, por exemplo, estar próximo a pontos de presença de redes de diversas concessionárias e prestadoras de serviços de telecomunicações; ter o seu fornecimento de energia elétrica assegurada em 100\%; e possibilitar escalabilidade, ou seja, permitir o aumento da área ocupada ao longo do tempo.

\subsubsection{Integração de Novas Aplicações com Sistemas Legados}

A integração de novos sistemas e novos serviços de atendimento junto com sistemas legados é um dos maiores problemas para a evolução tecnológica das plataformas de atendimento ao cliente.

Normalmente, o termo legado é aplicado a todo e qualquer sistema de informação que apresente algum tipo de obsolescência. Contudo, neste trabalho, quando um sistema for referido como legado, denotam-se apenas sistemas existentes previamente ao sistema proposto, e que deverão permanecer ainda em uso - pois complementam a solução ou não existe nada que justifique sua desativação. Portanto, define-se que sistemas legados são computadores, sistemas aplicativos, banco de dados, instalações de redes ou outros equipamentos que continuarão em uso, convivendo com um sistema mais moderno. 
Os sistemas legados devem permanecem em uso porque são essenciais ao funcionamento da empresa, apesar de apresentarem baixa compatibilidade e interoperabilidade com outros sistemas modernos. Continuam em funcionamento apenas porque o seu custo de aprimoramento ou substituição é muito elevado, ou porque ainda não surgiu uma alternativa viável para conversão do sistema legado para outra linguagem ou ambiente operacional mais integrável ou compatível com tecnologias modernas.

Os sistemas legados normalmente apresentam um ou mais características abaixo:

- Limitações de integração com outros sistemas;

- Restrições com relação ao desenvolvimento de novas funcionalidades;

- É processado em equipamento com altos custos de manutenção;

- Não são passíveis de acesso através da Internet;

- Desenvolvidos em plataformas proprietárias;

- Dificuldade para renovar equipe de desenvolvimento e suporte.

Geralmente o principal objetivo de um analista de integração é reduzir o tempo de desenvolvimento e reduzir a necessidade de adaptação dos sistemas legados. Este fim quase sempre é alcançado através dos Middlewares ${ }^{26}$. Quando se refere à integração de sistemas, na maioria das vezes trata-se do uso de Application Program Interfaces (API), também chamadas de applets, portlets, adaptadores ou conectores, sendo dessa forma o acesso mais facilitado às informações estruturadas, pois através das linguagens de programação padrão de mercado pode-se utilizar uma API que facilite o desenvolvedor de sistemas acessar as informações através de interfaces genéricas (INTEL, 2003).

\footnotetext{
${ }^{26}$ Middleware é o neologismo criado para designar camadas de software que não constituem diretamente aplicações, mas que facilitam o uso de ambientes ricos em tecnologia da informação. A camada de middleware concentra serviços como identificação, autenticação, autorização, diretórios, certificados digitais e outras ferramentas para segurança. Aplicações tradicionais implementam vários destes serviços, tratados de forma independente por cada uma delas. As aplicações modernas, no entanto, delegam e centralizam estes serviços na camada de middleware. Ou seja, o middleware serve como elemento que aglutina e dá coerência a um conjunto de aplicações e ambientes.
} 


\section{O CONTEXTO DA ENGENHARIA DE TRÁFEGO TELEFÔNICO}

\subsection{OBJETIVOS DO DIMENSIONAMENTO DE TRÁFEGO TELEFÔNICO}

Nas Considerações Iniciais desta dissertação foi demonstrado um problema de engenharia de tráfego telefônico. O objetivo da engenharia de tráfego telefônico em uma central de teleatendimento é predizer a quantidade de linhas, equipamentos e atendentes humanos através de métodos e modelos matemáticos estatísticos, de modo a atender certas métricas de qualidade de serviço.

Segundo Cox (1971), o dimensionamento de tráfego telefônico pela Teoria das Filas nos dirige pelo seguinte caminho:

a) Dimensionar o tamanho da Fonte de chamadas:

b) Inferir o Processo de Chegadas das chamadas;

c) Inferir o Processo de Atendimento das chamadas;

d) Determinar o Processo de Bloqueio de chamadas;

e) Modelar o Tráfego para cada sistema, considerando também as restrições de tamanho máximo de fila e priorização de atendimento;

f) Determinar a capacidade para o sistema suposto a partir do Modelo.

O problema indicado no subitem (a), que é o do dimensionamento do tamanho da fonte de chamadas, será mais bem explorado no Capítulo 8. Apresenta-se a seguir uma análise dos demais subitens.

\subsection{PROCESSO DE CHEGADA DE CHAMADAS}

Dentro do número de total de chamadas previstas para um Dia Crítico, as chamadas individualmente podem chegar com velocidades diferentes dentro de diferentes períodos desse dia. Quanto maior a taxa de chegada, mais canais de acesso deverá possuir o sistema de comunicação que atenderá estas chamadas. Sendo assim, há três cenários possíveis a considerar para o processo de chegadas de chamadas (Arrival Process):

- Padrão constante ou suave: tempo entre chegadas invariável, ou que varia muito pouco;

- Padrão com picos: apresenta grandes sobressaltos em relação a média, conhecido como um padrão de ordem hiperexponencial. Esse padrão é notadamente observado em dias atípicos, como Dias das Mães e Natal; 
- Padrão aleatório ou randômico: tempo entre chegadas de ordem exponencial, notadamente a Distribuição de Poisson (ver Gráfico 4).

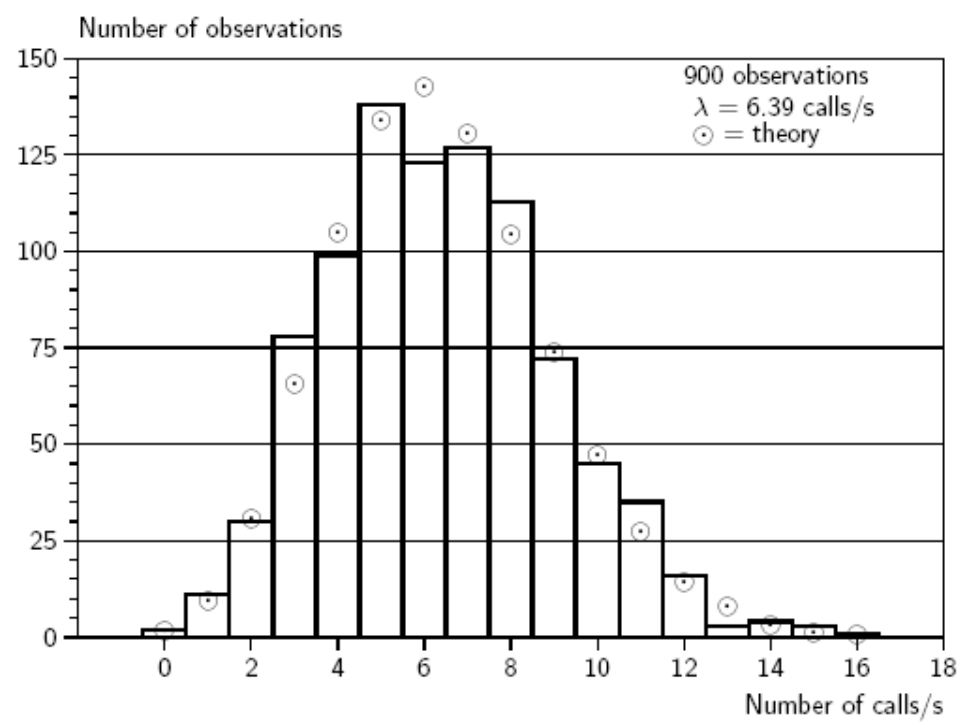

Fonte: [ITU, 2005, p. 110]

Gráfico 4: Exemplo de Distribuição de Poisson no Tráfego Telefônico

Pode-se ainda enfrentar um padrão desconhecido, como pode ser o caso dos Dias Críticos nas centrais de teleatendimento das distribuidoras de energia. Entretanto é possível ajustar esse padrão desconhecido para um determinado padrão conhecido ou previamente modelado.

As Recomendações E.733 (1998) e E.492 (1996) da International Telecomunication Union (ITU-T) sugerem um método de previsão e de ajuste, assumindo um processo exponencial. Nesse caso, é fundamental a medição precisa dos tempos entre chegadas históricos, da seguinte forma segundo a ITU-T:

- Deverá ser tomada uma série mensal de todos os meses do ano, de modo a cobrir a sazonalidade;

- Os dados mensais serão compostos de medidas de todos os dias do mês, e para cada dia deverá ser gravado a intensidade de pico (Daily Peak Period). Os períodos entre medições devem estar entre 5 a 15 minutos;

- Os dias do mês não homogêneos entre si devem ser expurgados (exemplo, finais de semana e feriados);

- Dentro de cada mês, ordenam-se os dados de pico diários, desde o menor até a maior intensidade de chegada de chamadas; 
- O dia de referência para intensidade normal de chegada de chamadas será o quarto maior dia de pico diário. O dia de referência para intensidade alta de chegada de chamadas será o segundo maior dia de pico diário;

- Recomenda-se o uso do dia de referência de intensidade normal para o dimensionamento dos sistemas, embora o dia de referência alta também possa ser considerado;

- Caso as medidas de referência entre os diversos meses sejam discrepantes, a ITU-T apresenta a Recomendação E.500 (1998), que provê um método de derivar as intensidades de tráfego normal e alto de forma anualmente representativa.

A Teoria das Filas (BEAR, 1976) indica que o padrão aleatório de chegada e a Distribuição de Poisson são aplicáveis quando as seguintes condições são satisfeitas:

- Variação randômica, devido a fatores não previsíveis;

- O número de clientes do universo do sistema é muito amplo;

- O impacto de um único cliente é muito pequeno;

- Todos os clientes tomam decisões de forma independente.

A Distribuição de Poisson para sistemas telefônicos tem a seguinte equação:

$$
A P\left(c, t_{a}\right)=\frac{e^{-\lambda \cdot t_{a}}\left(\lambda \cdot t_{a}\right)^{c}}{c !}
$$

sendo:

$\boldsymbol{A P}$ a função probabilidade da chegada de chamadas em um sistema telefônico, segundo uma Distribuição de Poisson;

c a quantidade de chamadas que entram em um sistema telefônico;

$\boldsymbol{t}_{\boldsymbol{a}} \quad \mathrm{o}$ intervalo de tempo entre a chegada de chamadas em um sistema telefônico [minutos];

$\lambda \quad$ a média da Distribuição de Poisson, ou a taxa média de chegada de chamadas em um sistema telefônico [chamadas/minuto].

\subsection{PADRÃO DE ATENDIMENTO DE CHAMADAS}

Há dois cenários possíveis a considerar para o processo de atendimento (Service Process):

- Padrão constante: tempo de atendimento invariável; 
- Padrão aleatório: tempo de atendimento de ordem exponencial negativa.

Segundo Cox (1971), a segunda alternativa é a mais provável porque o processo de atendimento, no mundo real, é influenciado pela quantidade de clientes que demandam serviço. Quanto mais demanda, mais rápido será o atendimento. Além disso, a decisão de quão longa será a conversa depende também de cada cliente. A probabilidade de um cliente fazer uma longa chamada é pequena (especialmente nos Dias Críticos).

Sabe-se que uma distribuição exponencial tem a seguinte característica (ver Gráfico 5):

$$
S P\left(t_{b}\right)=\mu \cdot e^{-\mu \cdot t_{b}}
$$

sendo:

a função probabilidade de atendimento de chamadas em um sistema telefônico, segundo uma Distribuição Exponencial Negativa;

$t_{b}$ o tempo de atendimento das chamadas de um sistema telefônico [s];

$\boldsymbol{\mu}$ o inverso do tempo médio de atendimento $\left[\mathrm{s}^{-1}\right]$;

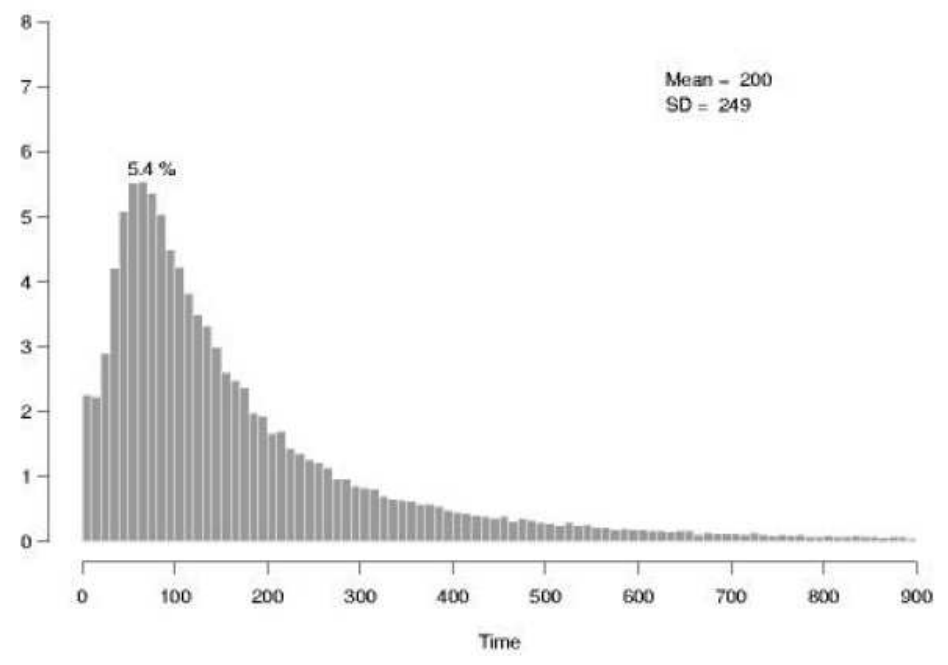

Fonte: [KOOLE, 2006b]

Gráfico 5: Distribuição de Probabilidade de Atendimento obedecendo uma Exponencial Negativa

O inverso da taxa média do tempo de atendimento $\boldsymbol{\mu}$ é um valor a ser adotado como meta interna de cada concessionária. É de se esperar que nos Dias Críticos esses valores sejam semelhantes, ou menores até, em relação aos Dias Típicos. 


\subsection{PROCESSO DE BLOQUEIO DE CHAMADAS.}

Numa situação de congestionamento de um sistema de filas quatro abordagens particulares das equações anteriores (1) e (2) são descritas por Bear (1976):

- Lost Calls Cleared (LCC): Esse modelo admite bloqueio de chamadas excedentes e a completa liberação destas do sistema, ou seja, as chamadas são definitivamente perdidas. As chamadas atendidas são imediatamente transferidas para atendimento;

- Lost Calls Retried (LCR): Assume que uma vez bloqueada uma chamada, uma porcentagem dos clientes faz novas tentativas até obter o serviço de atendimento;

- Lost Calls Delayed (LCD): As chamadas bloqueadas permanecem no sistema até o serviço de atendimento ser prestado, ou seja, as chamadas permanecem em uma espera e, portanto sofrem um atraso de atendimento;

- Lost Calls Held (LCH): Uma chamada introduzida no sistema é presa ao sistema por um finito montante de tempo. Todas as chamadas, inclusive as que foram bloqueadas, estão presas ao sistema até determinado tempo.

\subsection{MODELOS DE TRÁFEGO}

\subsubsection{Modelo Geral para $m$ Servidores (linhas)}

Segundo a Teoria das Filas, para a disciplina de fila FIFO (Fist In, Fist Out), Cox (1971) relata que:

$$
\rho=\frac{\lambda}{\mu}
$$

, sendo $\boldsymbol{\rho}$ a taxa de utilização do sistema de sistemas telefônicos, comumente chamado de tráfego telefônico, dada em Erlangs.

Todas as demais equações de modelamento de tráfego derivam da Equação (3), conforme as equações gerais abaixo:

$$
\begin{aligned}
& \rho_{1}=\frac{\lambda_{0}}{\mu_{1}} \cdot \rho_{0} \quad \rho_{2}=\frac{\lambda_{0} \lambda_{1}}{\mu_{1} \cdot \mu_{2}} \cdot \rho_{0} \\
& \rho_{2}=\frac{\lambda_{0} \lambda_{1} \ldots \lambda_{n-1}}{\mu_{1} \cdot \mu_{2} \ldots \mu_{n}} \cdot \rho_{0} \\
& \frac{1}{\rho_{0}}=S=1+\frac{\lambda_{0}}{\mu_{1}}+\frac{\lambda_{0} \cdot \lambda_{1}}{\mu_{1} \mu_{2}}+\ldots+\frac{\lambda_{0} \lambda_{1} \ldots \lambda_{n-1}}{\mu_{1} \cdot \mu_{2} \ldots \mu_{n}}
\end{aligned}
$$


Para uma fila de $\boldsymbol{m}$ servidores:

$$
\begin{array}{ll}
S=1+\frac{\lambda}{\mu}+\frac{\lambda^{2}}{2 ! \mu^{2}}+\ldots+\frac{\lambda^{m-1}}{(m-1) ! \mu^{(m-1)}}+\frac{m^{m-1}}{(m-1) !} \sum_{n=m}^{\infty}\left(\frac{\lambda}{m \mu}\right)^{n} \\
\rho=\lambda \cdot(m \cdot \mu)^{-1} & (n<m) \\
\rho_{n}=S^{-1} \cdot \frac{(m \rho)^{n}}{n !} & (n \geq m)
\end{array}
$$

Diversos modelos foram particularizados a partir das equações acima. A Tabela 6 a seguir resume de forma comparativa modelos particulares de tráfego telefônico, considerando o tamanho da fonte de chamadas, o processo de chegada, de atendimento e de bloqueio.

Tabela 6: Comparação de Modelos de Tráfego Telefônico

\begin{tabular}{|c|c|c|c|c|}
\hline Modelo de Tráfego & $\begin{array}{c}\text { Fonte de } \\
\text { Chamadas }\end{array}$ & $\begin{array}{c}\text { Padrão de } \\
\text { Chegada }\end{array}$ & $\begin{array}{c}\text { Padrão de } \\
\text { Atendimento }\end{array}$ & $\begin{array}{c}\text { Padrão de } \\
\text { Bloqueio }\end{array}$ \\
\hline Erlang B & Infinita & Aleatório & Exponencial & Cleared \\
\hline Extended Erlang B & Infinita & Aleatório & Exponencial & Retried \\
\hline Erlang $C$ & Infinita & Aleatório & Exponencial & Delayed \\
\hline Poisson & Infinita & Aleatório & Exponencial & Held \\
\hline Neal-Wilkerson & Infinita & Pico & Exponencial & Held \\
\hline Binomial & Finita & Aleatório & Exponencial & Held \\
\hline
\end{tabular}

Fonte: CISCO, 2006a.

Este trabalho detém-se aos modelos de tráfego de Erlang B, Extend Erlang B e Erlang $C$, por serem universalmente aceitos para o cálculo de centrais de atendimento telefônico. A análise dos demais modelos ficará para futuros trabalhos.

\subsubsection{Os Modelos Erlang B e Extended Erlang B}

Uma situação particular descrita por Cox (1971) indica que para chamadas em um sistema telefônico com uma sala de espera finita, tem-se:

$$
E_{1}=\rho_{n}=\frac{\frac{1}{k !}\left(\frac{\lambda}{\mu}\right)^{n}}{1+\left(\frac{\lambda}{\mu}\right)+\frac{1}{2 !}\left(\frac{\lambda}{\mu}\right)^{2}+\ldots+\frac{1}{k !}\left(\frac{\lambda}{\mu}\right)^{k}}
$$


sendo:

$\boldsymbol{E}_{\boldsymbol{I}} \quad$ a proporção de tempo que um sistema telefônico está totalmente ocupado; é também em termos de chamadas, a proporção de chamadas perdidas (ou não atendidas) [\%];

$\boldsymbol{k} \quad$ a quantidade de linhas telefônicas necessárias para um sistema telefônico;

$\mathbf{E}_{\mathbf{1}}$ é também a probabilidade de encontrar todos os troncos ocupados. A Equação (6) é chamada de Equação B de Erlang. Devido ao processo de chegadas admitir uma distribuição de Poisson, a Equação (6) também representa a proporção de chamadas congestionadas em um sistema com espera limitada (BEAR, 1976).

A.K Erlang, no ano de 1918, criou a Equação (6), considerando as seguintes premissas:

a) As chamadas ocorrem individualmente e de forma aleatória. Isso implica num número amplo de fontes chamadoras (clientes);

b) As tentativas de chamadas quando todos os troncos estão ocupados serão bloqueadas. Segundo Bear (1976), o efeito repetitivo de tentativas não bem sucedidas é ignorado, mas isso não representaria uma séria fonte de erros;

c) Distribuição de tempo do processo de atendimento conforme curva exponencial negativa;

d) Os clientes que são bloqueados não voltam a originar chamadas. Os clientes fazem uma única tentativa. Dessa forma, ela só pode ser usada quando a possibilidade de bloqueio esperada é baixa.

Posteriormente, nos meados de 1970, James Jewitt e Jacqueline Shrago desenvolveram um aprimoramento deste modelo, denominado-o Extend Erlang B, e usando as mesmas premissas originais de A.K. Erlang, com exceção da d), que leva em consideração que uma porcentagem dos clientes bloqueados inicialmente voltam a originar chamadas até obter sucesso. Esse modelo é mais comumente usado nas centrais de teleatendimento, porque descreve uma situação mais real do comportamento dos clientes. Esse comportamento de rechamadas aumenta o tráfego demandado, e também aumenta a taxa de chamadas bloqueadas. Para aplicar a equação Extend Erlang $B$ é necessário ter a porcentagem esperada de novas tentativas. 
É importante notar que as Equações de Erlang não podem ser resolvidas de modo direto, apenas de forma iterativa ou através de tabelas pré-elaboradas. Calculadoras automáticas foram recentemente desenvolvidas pelo matemático Ger Koole da Universidade de Amsterdam, e são utilizadas neste trabalho ${ }^{27}$.

\subsubsection{Modelo Erlang C}

Sistemas telefônicos sem bloqueio, ou seja, com fila infinita, também foram modelados por A. K. Erlang. As premissas anteriores de Erlang foram mantidas, com exceção da premissa d) que foi substituída por: clientes que originam chamadas quando todos os atendentes estão ocupados, esperam o tempo necessário para serem conectados, e são conectados imediatamente quando um atendente tornar-se livre.

O modelo Erlang $C$ é comumente usado em PABX com DAC, basicamente para determinar o número de Posições de Atendimento (agentes) necessários para evitar um determinado tempo máximo de fila de espera.

O modelo Erlang $C$ é representado pela equação abaixo:

$$
E_{2}=\rho_{k}=\frac{\frac{A^{k}}{\alpha !}\left(\frac{\alpha}{\alpha-A}\right)}{\left(\sum_{r=0}^{\alpha-1} \frac{A^{r}}{r !}\right)+\frac{A^{\alpha}}{\alpha !}\left(\frac{\alpha}{\alpha-A}\right)}
$$

sendo:

$\boldsymbol{E}_{2} \quad$ a probabilidade de espera ou atraso em um sistema telefônico, comumente chamada de Nível de Serviço [\%]; é também a probabilidade de todas as $\boldsymbol{\alpha}$ Posições de Atendimento estarem ocupadas;

$\alpha$ a quantidade de Posições de Atendimento em um sistema telefônico;

$\mathbf{A}$ a taxa média de utilização do sistema telefônico, ou tráfego médio em um sistema telefônico [Erlang], onde $A=\lambda / \mu$.

Para estudos considerando o horário de maior movimento, não se trabalha com os valores médios de $\boldsymbol{A}$, e sim os valores de pico.

\footnotetext{
${ }^{27}$ As calculadoras automáticas estão disponíveis on-line em: <http://www.math.vu.nl/ koole>.
} 
O Tempo Médio de Espera (TME), dados em segundos, é:

$$
T M E=\frac{E_{2}}{\alpha-A}
$$

A probabilidade, em termos porcentuais, de o atraso em fila exceder o TME é:

$$
T S F=E_{2} \cdot e^{-(\alpha-A) T \bar{M} E}
$$

Nota-se que essa probabilidade é uma exponencial negativa.

Há variantes da Equação $C$ de Erlang, onde pode ser simulada uma provável taxa de abandono de chamadas, além de calcular a cada intervalo de tempo (no período de um dia) qual seria a quantidade variável de agentes requerida para manter o sistema em equilíbrio.

\subsubsection{As Limitações do Modelamento de Erlang}

A.K. Erlang foi pioneiro no estudo da teoria das filas para sistemas telefônicos. Para isso, ele adotou em seu estudo diversas premissas, as quais ainda estão em uso e constituem a base da Engenharia de Tráfego Telefônico (Bear, 1976). Essas premissas são simplificações que ignoram certas nuances do mundo real, conforme lista abaixo:

- Tentativas repetitivas: numa primeira instância, assume-se que um cliente que ao tentar acessar um centro de atendimento telefônico, e não obtém sucesso inicialmente, não repete a tentativa de chamada ou demora a repetir a tentativa. A.K. Erlang também assumiu que existe uma proporção fixa de cliente que irão repetir com novas tentativas até obter sucesso. Mas posteriormente esse comportamento de repetição foi mais bem acurado através do modelo Extended Erlang B;

- Abandono de chamadas: admite-se que um cliente, uma vez numa fila de espera, permanece na fila até ser atendido, sendo que na verdade um longo atraso na fila causa certa proporção de abandono de fila. Normalmente este efeito é negligenciado, mas em situações de grande tráfego, a taxa de abandono pode ser significativa. De uma forma simplificada, considera-se que uma situação de equilíbrio é atingida quando os clientes estão preparados para esperar de forma exponencial negativa, mas na prática o comportamento humano muda de forma imprevisível; 
- Horário de maior movimento: O horário de maior movimento é o período do dia em que a demanda de tráfego é máxima. São pontos da curva que representam um desequilíbrio do sistema, e normalmente a taxa de bloqueio de chamadas é maior. Os modelos de tráfego de Erlang trabalham com as condições médias, logo não equacionam diretamente essa condição. A maneira mais comum de lidar com este problema é estipular uma taxa permitida de bloqueio para dada porcentagem de tráfego superior a média;

- Tamanho infinito das filas: Na prática, o recurso de fila de espera é limitado, e sujeito ao estouro de capacidade. Nesse caso, os clientes irão receber um sinal de ocupado ou um redirecionamento para outro sistema. Além disso, um PABX com DAC pode implementar estratégias de transbordo entre filas distintas, conforme o tamanho da fila principal;

- Saída de ligações: Ao contrário da chegada de chamadas, alguns atendentes podem realizar ligações de retorno aos clientes, conforme fluxo de informações ou estratégia de resolução de problemas. Essas ligações consomem recursos do sistema;

- Os atendentes são seres humanos: A. K. Erlang assumiu que todos os recursos do sistema trabalham com máxima capacidade e disponibilidade. Isso é adequado dizer para as linhas telefônicas e computadores, mas não para os recursos humanos, que por vezes precisam descansar, fazer treinamentos e ou outras tarefas, tirar férias, cuidar da saúde, etc..

Devido a essa complexidade, é de vital importância usar o bom senso na engenharia de tráfego telefônico. Em um cenário de grande volume de chamadas, a aproximação de certos fatores pode conduzir a erros significantes; logo a análise de sensibilidade é necessária para complementar o exame. 


\section{PROPOSTA DE PREVISÃO DE CHAMADAS OFERECIDAS PARA DIAS CRÍTICOS}

A construção desta proposta seguiu-se através de um processo indutivo, composto dos seguintes passos e da seguinte lógica, pela ordem:

- Identificação e classificação das variáveis por abstração;

- Estudo de caso particular;

- Modelamento matemático genérico;

- Aplicação do modelo proposto;

- Discussão e validação dos resultados.

A aplicação do método proposto está contida no Capítulo 9, e a sua discussão no Capítulo 10.

\subsection{IDENTIFICAÇÃO E CLASSIFICAÇÃO DAS VARIÁVEIS}

Prever a mais provável quantidade de Chamadas Oferecidas (COf) trata-se de prever a quantidade de consumidores interrompidos e a porcentagem destes que provavelmente tentarão estabelecer uma ligação telefônica para a Central de Teleatendimento. É uma tarefa que envolve discutir diversas variáveis. Para essas variáveis foram identificadas duas classes, as quais serão chamadas arbitrariamente de "Internas" e "Externas".conforme a Tabela 7:

Tabela 7: Classificação das Variáveis do Modelo

\begin{tabular}{|c|c|}
\hline INTERNAS & EXTERNAS \\
\hline $\begin{array}{l}\text { Número total de consumidores da região de } \\
\text { concessão }\end{array}$ & Agrupamento de consumidores em condomínios \\
\hline Número de circuitos elétricos primários & $\begin{array}{l}\text { Porcentagem de ligações normais e ligações de } \\
\text { emergência na Central de Teleatendimento }\end{array}$ \\
\hline Densidade de consumidores por $\mathrm{Km}^{2}$ & Disponibilidade da rede telefônica pelo consumidor \\
\hline $\begin{array}{l}\text { Quantidade (média) de consumidores por circuito } \\
\text { primário }\end{array}$ & Simultaneidade dos eventos de interrupção \\
\hline $\begin{array}{l}\text { Condições prévias dos circuitos primários (taxa de } \\
\text { falhas) }\end{array}$ & Tempo de interrupção dos circuitos \\
\hline \multirow[t]{3}{*}{ Concentração de carga em grandes consumidores } & Sazonalidade climática \\
\hline & Padrões comportamentais dos consumidores \\
\hline & $\begin{array}{l}\text { Obtenção de informação adequada e em tempo real } \\
\text { através de outras mídias pelo consumidor }\end{array}$ \\
\hline
\end{tabular}


As variáveis da classe "Interna" são ditadas pelas dimensões da rede de distribuição primária, e passíveis de determinação teórica pela distribuidora de energia com tanta exatidão quanto se deseje. No entanto, as variáveis da classe "Externas" são do tipo exógeno e na maioria das vezes apresentam comportamento bastante aleatório, e só podem ter seu valor estimado por pressuposições. Algumas dessas variáveis podem ser encaixadas em ambas as classes, e estas foram classificadas pelo fator julgado predominante. A seguir uma breve análise de cada uma das variáveis, de acordo com a sua classe:

\subsubsection{Variáveis Internas}

- Número total de consumidores e de circuitos elétricos primários na região de concessão: uma concessionária com poucos consumidores e, conseqüentemente, com poucos circuitos elétricos primários, certamente enfrenta baixa dificuldade em prever quantos consumidores serão afetados com uma eventual interrupção em massa. Mas seguramente este não é o caso das concessionárias dos Grupos I e II, de acordo com a definição da Resolução № 57/2004 da ANEEL. Quanto mais consumidores, e mais circuitos elétricos primários, maior será o volume esperado de consumidores interrompidos, e também, possivelmente, maior a imprecisão das previsões desse volume;

- Densidade de consumidores por $\mathrm{Km}^{2}$ : Em zonas rurais, as concessionárias contam com uma diversidade de ocorrências por conta de extensas áreas geográficas, de modo que a probabilidade de desligamentos de muitos circuitos num curto intervalo de tempo é proporcionalmente menor do que em regiões de maior densidade, o que facilita o atendimento tanto das ocorrências como das reclamações dos clientes. $\mathrm{O}$ mesmo não ocorre em zonas urbanas e metropolitanas. Ou seja, quanto maior a densidade de consumidores, maior a probabilidade de desligamentos de muitos consumidores;

- Quantidade (média) de consumidores por circuito elétrico primário: Mais consumidores por circuito elétrico primário significa maior probabilidade que muitos consumidores sejam afetados por uma eventual interrupção desses diversos circuitos; 
- Condições prévias dos circuitos primários (taxa de falhas): Há certos circuitos primários mais sensíveis às falhas, e que são interrompidos com mais frequiência. Os consumidores conectados a estes circuitos podem apresentar comportamento diverso dos demais consumidores da região de concessão;

- Concentração de carga em grandes consumidores: este tipo de consumidor geralmente representa carga concentrada nos circuitos primários, o que pode alterar a relação média consumidores por circuito. Além disso, os grandes consumidores podem encontrar canais de comunicação diferenciados, desviando suas chamadas da Central de Teleatendimento convencional.

\subsubsection{Variáveis Externas}

- Agrupamento de consumidores em condomínios: Com o crescimento de condomínios verticais, observa-se a concentração de consumidores individuais que irão se comunicar apenas entre si ou com um agente central responsável pelo condomínio (portaria, síndico). A comunicação prévia do agente condominial com a distribuidora pode adiar ou evitar a ligação individual de cada consumidor para a Central de Teleatendimento;

- Porcentagem de ligações normais e ligações de emergência na Central de Teleatendimento: Em uma região de concessão muito dispersa, os eventos de interrupção de emergência são localizados. Dessa forma, outra região distante de um evento atípico continua a gerar ligações normais como, por exemplo, a solicitação de serviços comerciais;

- Disponibilidade da rede telefônica pelo consumidor: Em eventos causados por tempestade ou tornados, é possível que a rede telefônica de parte dos consumidores interrompidos também esteja indisponível, o que impossibilita que o consumidor acesse a Central de Teleatendimento via linha telefônica fixa. Consumidores sem acesso a uma linha telefônica móvel, neste caso, não poderão originar chamadas;

- Sazonalidade climática: Diferentes períodos do ano apresentam aos circuitos aéreos diferentes riscos de interrupção. Dentro de um mesmo ano há época de piores condições climáticas. Ao ser comparado um ano com outro ano, também encontrar-seá diferenças. Na fase de coleta de dados quanto mais abrangente os períodos de observação, mais as diferenças de sazonalidade serão neutralizadas; 
- Tempo de interrupção dos circuitos: Normalmente em um evento de diversas interrupções de emergências, nem todos os circuitos primários são desligados simultaneamente, e nem todos são religados ao mesmo tempo. O tempo de religamento depende dos métodos de localização da falha, da dificuldade de reparo e da priorização que a distribuidora dará àquele circuito. Seguramente poder-se-á indicar tempos médios de religamento, mas é certo que haverá certos consumidores que serão brevemente (em termos relativos) restaurados, e haverá outros que esperarão muitas e muitas horas. Existe certa sensibilidade individual para cada consumidor, mas é também apropriado afirmar que quanto mais tempo demorar a restauração, mais a massa de consumidores dos circuitos afetados sentirão propensão a fazer uma ou mais ligações à Central de Teleatendimento;

- Padrões comportamentais do consumidor: Admite-se que nem todos os consumidores afetados por uma interrupção de emergência irão fazer contato, isso por diversas razões práticas, até mesmo psicológicas. Exemplo no caso de consumidores residenciais: uma parte não saberá para qual número ligar, alguns não estarão presentes no domicílio afetado, outros esperarão seu vizinho tomar essa atitude, mas certamente haverá certos consumidores impacientes que ligarão diversas vezes. A princípio, admite-se que o comportamento do consumidor é aleatório, ou seja, o comportamento de certo indivíduo é independente do comportamento de outro indivíduo, pois cada consumidor toma decisões próprias. À medida que o tamanho da população consumidora estudada aumenta, este comportamento aleatório torna-se mais evidente;

- Obtenção de informação adequada e em tempo real através de outras mídias pelo consumidor: Este trabalho identifica e sugere outras formas de informar em tempo real os consumidores. Na medida em que estes novos meios de comunicação forem introduzidos pela distribuidora, e dependendo do sucesso da implementação, e da abrangência e penetração desses novos meios, uma parcela (eventualmente significativa) de consumidores poderá deixar de usar o meio de comunicação telefônico tradicional. 


\subsection{ESTUDO DE CASO PARTICULAR}

A CPFL Paulista, distribuidora do interior do Estado de São Paulo, forneceu dados relevantes sobre o histórico de chamadas em sua Central de Teleatendimento, dados referentes aos anos de 2004, 2005 e de parte de 2006. Os dados continham:

- Quantidade total diária de chamadas oferecidas na Central de Teleatendimento (CTA), com medidas de hora em hora;

- Quantidade total diária de circuitos primários interrompidos;

- Porcentagem de chamadas ocupadas em relação às chamadas oferecidas à CTA, medidas mensalmente;

- Quantidade média de consumidores para a classe de tensão de $15 \mathrm{kV}$;

- Valores anualizados dos Indicadores de Qualidade FEC e DEC;

- Quantidade total de consumidores na região de concessão;

- Quantidade de Posições de Atendimento (PA) da CTA;

- Quantidade de linhas da CTA com a concessionária de serviço telefônico;

- Quantidade de canais da Unidade de Resposta (URA) da CTA;

- Informações em geral sobre estratégias de operação da CTA.

A partir destes dados foi possível o cálculo da quantidade de Chamadas Oferecidas (COf) esperado da concessionária para um Dia Crítico, comparando o valor teórico com o valor histórico. Posteriormente, tais cálculos particulares foram generalizados, transformandoos no modelo aqui proposto. 


\subsection{MODELAMENTO ESTATÍSTICO DAS CHAMADAS OFERECIDAS}

O estudo de caso mostrou que a correlação entre as variáveis identificadas tem uma complexidade tal que é difícil isolar os fatores determinando um comportamento exato. A saída encontrada neste trabalho foi usar um modelamento estatístico ${ }^{28}$.

\subsubsection{Tratamento Geral das Variáveis}

Neste trabalho serão parcialmente ou totalmente desconsiderados certos fatores, pois é uma hipótese que a introdução destes traria complexidade ao modelamento, sem efeito significativo na exatidão dos resultados:

- Condições prévias dos circuitos: admite-se em tese que circuitos primários do universo estudado têm probabilidade de falha não muito diferente entre si, e que a falha de um circuito não implica em outro, ou seja, todos os eventos de falhas são independentes. Isso pode não ser necessariamente verdadeiro quando uma subestação transformadora ou linhas de transmissão ficam inoperantes, mas espera-se que este tipo de evento seja muito menos freqüente;

- Concentração de carga nos circuitos primários: admite-se que não há região com uma concentração muito maior que as outras, ou que seja desprezível este efeito;

- Porcentagem de ligações normais e ligações de emergência: os dados referentes às ligações solicitando atendimento comercial não serão expurgados da análise;

- Disponibilidade da rede telefônica pelo consumidor desligado: admite-se que a rede telefônica estará sempre ativa, ou que o consumidor terá sempre meios de acesso à Central de Teleatendimento;

- Tempo de restauração: admite-se que todos os desligamentos serão resolvidos dentro do período de até um dia após a ocorrência, não importando encadeamento individual dos eventos de interrupção ou a sequiência da resolução dos problemas;

\footnotetext{
${ }^{28}$ Uma outra abordagem, menos convencional, seria utilizar técnicas de Inteligência Artificial, como por exemplo, Redes Neurais ou Lógica Fuzzy.
} 
As demais variáveis serão reunidas em cinco grupos, de acordo com a sua ordem de resolução:

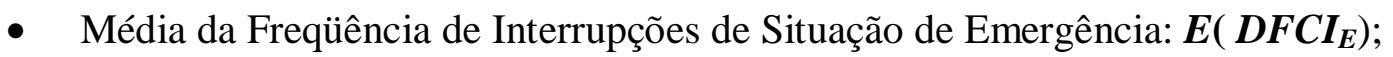

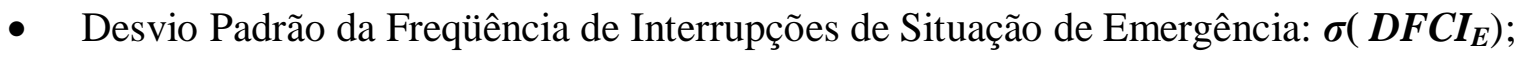

- Volume Máximo Esperado de Chamadas Oferecidas para um Dia Crítico: VMax Cof $_{\text {; }}$;

- Volume Médio Esperado de Chamadas Oferecidas para um Dia Crítico: VMed Cof $_{\text {; }}$;

- Volume Esperado de Chamadas Oferecidas para um Dia Crítico: $\boldsymbol{V E}_{\boldsymbol{C O} \boldsymbol{f}}$.

\subsubsection{Média e Desvio Padrão da Freqüiência de Interrupções de Situação de Emergência}

Segundo a Resolução № 24 de 27 de Janeiro de 2000 da ANEEL, a concessionária de distribuição deverá apurar os indicadores de continuidade considerando as interrupções com duração maior ou igual a 3 minutos, ou seja, é considerada uma interrupção de longa duração toda interrupção do sistema elétrico com duração maior ou igual a 3 minutos. De posse desses dados da concessionária, os procedimentos são:

a) Para cada classe de tensão de circuitos primários da concessionária, dispor de uma tabela da Quantidade Histórica de Circuitos Interrompidos em Situação de Emergência $\left[\boldsymbol{C I}_{\boldsymbol{H}}\right]$, numericamente definida pela quantidade diária de circuitos primários interrompidos em situação de emergência no período dos últimos 24 meses;

b) Construir o Histograma de Freqüiências de $\boldsymbol{C I}_{\boldsymbol{H}}$, determinando assim uma Distribuição Histórica de Freqüências da Quantidade de Circuitos Interrompidos em Situação de Emergência [ $D F C I_{H}$ ];

c) Escolher uma curva de distribuição teórica (Normal, Gama, Log-Normal, Poisson, etc.) que mais se ajusta aos dados históricos em $\boldsymbol{D F C I}$;

d) A partir dessa escolha, podem ser realizados testes de aderência, dos quais os mais comuns são o Qui-Quadrado e Kolmogonov-Sminnov, sendo que alguns dados históricos não homogêneos podem ser expurgados. Atualmente há disponíveis programas de computador que fazem esse ajuste de forma automática; 
e) Aceitando a escolha, obter-se-á a Distribuição Esperada de Freqüências da Quantidade de Circuitos Interrompidos em Situação de Emergência [ $D_{F C I}$ ]. Para

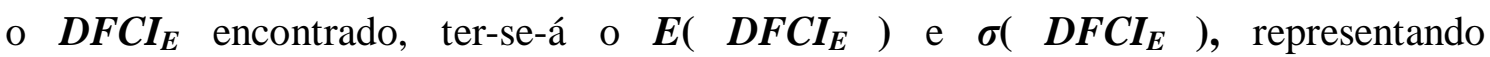

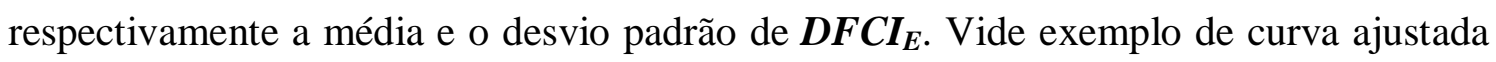
no Gráfico 6.

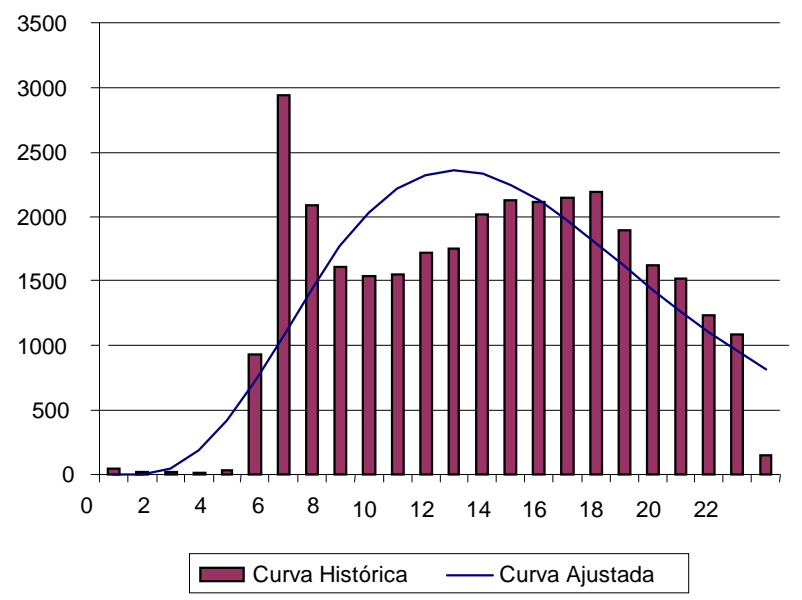

Gráfico 6: Exemplo de Curva Ajustada para Distribuição Gama de uma Curva Histórica

\subsubsection{Volume Máximo Esperado de Chamadas Oferecidas para um Dia Crítico}

Uma vez conhecido $\boldsymbol{E}\left(\boldsymbol{D F} \boldsymbol{C I} \boldsymbol{I}_{\boldsymbol{E}}\right)$ e $\boldsymbol{\sigma}\left(\boldsymbol{D F} \boldsymbol{C I} \boldsymbol{I}_{\boldsymbol{E}}\right)$ de cada classe tensão, define-se que o valor esperado para Volume Máximo de Chamadas Oferecidas [VMax $\boldsymbol{C o f}_{\text {] }}$ para um Dia Crítico qualquer será:

$$
\operatorname{VMax}_{C O f}=\sum_{i=1}^{j}\left[E_{\left(D Q C I_{C}\right)}+3 \sigma_{\left(D Q C I_{C}\right)}\right]_{i} \cdot\left(N C_{m}\right)_{i}
$$

sendo:

j o número total de classes de tensão de circuitos primários da concessionária;

$\boldsymbol{i} \quad$ o índice da classe de tensão dos circuitos primários, variando de 1 até $\mathbf{j}$;

$\boldsymbol{N C}_{\boldsymbol{m}} \quad$ o número médio de consumidores por circuito e classe de tensão primária.

Para a variável $\boldsymbol{N} \boldsymbol{C}_{\boldsymbol{m}}$, cada concessionária tem suas características. Este número varia conforme o tipo de consumidor (residencial, comercial, industrial), sua carga elétrica, tensão de fornecimento e a concentração de consumidores e de carga. Ou seja, varia de bairro a bairro, cidade a cidade, dentro da área de concessão da distribuidora. 
Todavia, de uma forma global, supõe-se que não afeta significativamente a previsão de volume de chamadas quando, para determinar a quantidade média de consumidores por circuito primário, a concessionária divida a quantidade total de consumidores pelo número total de circuitos por classe de tensão primária.

Provavelmente cada concessionária tem procedimentos internos próprios de determinar essa média sem grandes erros, mas caso a empresa tenha uma completa gerência automatizada sobre a sua rede primária e secundária, será possível determinar com exatidão a quantidade de consumidores para cada circuito primário e sua freqüência histórica de interrupção de emergência. E para estes casos, o total de $V_{M a x}$ cof será a soma parcial dos VMax $_{C o f}$ de cada circuito primário da concessionária.

\subsubsection{Volume Médio Esperado de Chamadas Oferecidas para um Dia Crítico}

Será preciso encontrar com certa precisão o padrão comportamental do consumidor de cada distribuidora, pois trabalhar com o Volume Máximo Esperado de Chamadas Oferecidas $\left[\right.$ VMax $\left._{C o f}\right]$ pode sobredimensionar desnecessariamente um sistema de atendimento.

O Volume Médio Esperado de Chamadas Oferecidas [ $\boldsymbol{V M e d}_{\boldsymbol{C o f}}$ ] pode ser obtido através da hipótese que o padrão comportamental da população consumidora da região de concessão pode ser encontrado. Esse padrão será chamado de Fator $\boldsymbol{P}$, de modo que:

$$
\text { VMed }_{\text {COf }}=\mathrm{P} \cdot \text { VMax }_{\text {COf }} \quad(0<\mathrm{P} \leq 1)
$$

Uma sugestão de como determinar o Fator $\boldsymbol{P}$, que é função do número total de Consumidores Desligados [Desl], pode ser encontrada no item 8.4.

\subsubsection{Volume Esperado de Chamadas Oferecidas para um Dia Crítico}

Tem-se a considerar que o Fator $\boldsymbol{P}$ pode variar de acordo com um desvio padrão $\boldsymbol{\varphi}$, como conseqüência da dispersão e da incerteza em relação a média adotada. Dessa forma, implica que o Volume Esperado de Chamadas Oferecidas [ $\boldsymbol{V} \boldsymbol{E}_{\boldsymbol{C} \boldsymbol{O} \boldsymbol{f}}$ ] estará entre o limite superior e inferior transcrito nas equações abaixo:

Limite superior de $V E_{C O f}=(\mathrm{P}+q \cdot \varphi) \cdot \operatorname{VMax}_{C O f}$

Limite inferior de $V E_{C O f}=(\mathrm{P}-q \cdot \varphi) \cdot \operatorname{VMax}_{C O f}$

sendo: 
um número multiplicador do desvio padrão $\boldsymbol{\varphi}$;

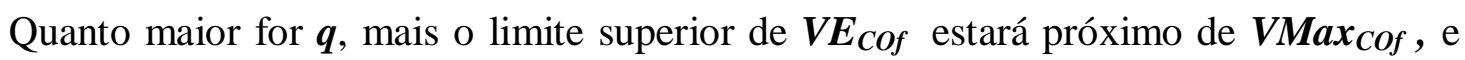
mais confiânça poder-se-á ter que os valores reais do dia-a-dia estarão dentro do intervalo projetado. Contudo, quanto maior for $\boldsymbol{q}$, maior a chance de sobredimensionar a Central de Teleatendimento.

\subsection{CÁLCULO DE P E $\varphi$}

De acordo com a Resolução № 57/2004 da ANEEL, admite-se a ciência dos seguintes dados pela distribuidora de energia:

$C A$

Chamadas Atendidas, sendo a quantidade diária de chamadas telefônicas atendidas eletronicamente ou não eletronicamente na Central de Teleatendimento;

CO Chamadas Ocupadas, sendo a quantidade diária de chamadas telefônicas que não puderam ser completadas e atendidas por falta de capacidade da Central de Teleatendimento, e apuradas em um período idêntico de $\boldsymbol{C A}$;

ICO Índice diário de Chamadas Ocupadas, devido ao congestionamento das linhas de acesso da Central de Teleatendimento da distribuidora de energia, informadas pela operadora de serviço telefônico [\%], e apuradas em um período idêntico de $\boldsymbol{C A}$;

A distribuidora de energia também deverá conhecer:

$N C_{m}$

$\boldsymbol{C I}_{\boldsymbol{H}}$ a Quantidade Histórica de Circuitos Interrompidos em Situação de Emergência, e apuradas em um período idêntico de CA;

Para cada classe de tensão primária da distribuidora, o mais provável número total de Consumidores Desligados $\left[\boldsymbol{D}_{\text {esl }}\right]$ no dia $\boldsymbol{W}$ (sendo $\boldsymbol{W}$ um Dia Crítico ou não crítico da operação da rede de distribuição primária da concessionária em estudo) de estudo será:

$$
\left(D_{e s l}\right)_{W}=N C_{m} \cdot\left(C I_{H}\right)_{W}
$$


Considerando todas as classes de tensão da distribuidora, o valor de $\boldsymbol{D}_{\boldsymbol{e s l}}$ para o dia $\boldsymbol{W}$ será:

$$
\left(D_{e s l}\right)_{W}=\sum_{i=1}^{j}\left\{\left(N C_{m}\right)_{i} \cdot\left[\left(C I_{H}\right)_{W}\right]_{i}\right\}
$$

sendo:

$j \quad$ o número total de classes de tensão de circuitos primários da concessionária;

$\boldsymbol{i} \quad$ o índice da classe de tensão dos circuitos primários, variando de 1 até $\mathbf{j}$;

Sabe-se pela Resolução № 57/2004 da ANEEL que:

$$
\begin{aligned}
& I C O=\frac{\text { Total de CO }}{\text { Total de COf }} \cdot 100 \\
& \Rightarrow C O=I C O \cdot C O f
\end{aligned}
$$

Pela definição de $\boldsymbol{C A}$, sabe-se também que:

$$
C O f=C A+C O
$$

Unindo-se a equação 17 com 18 , a quantidade total de Chamadas Oferecidas [COf] real e medido na Central de Teleatendimento no dia $\boldsymbol{W}$ é:

$$
(C O f)_{W}=(C A)_{W} \cdot \frac{1}{1-(I C O)_{W}}
$$

Para o dia $\boldsymbol{W}$, define-se a relação $\boldsymbol{\beta}$ como sendo a relação entre a quantidade total de Chamadas Oferecidas e o número total de Consumidores Desligados:

$$
(\beta)_{W}=\frac{(C O f)_{W}}{\left(D_{e s l}\right)_{W}}
$$

$\boldsymbol{W}$ pode varia de $\boldsymbol{W}_{\boldsymbol{0}}$ até $\boldsymbol{W}_{\boldsymbol{d}}$, sendo $\boldsymbol{d}$ um número inteiro representando o total de dias apurados no estudo. Para o dia $\boldsymbol{W}_{\boldsymbol{d}}$, a relação $\boldsymbol{\beta}$ será:

$$
(\beta)_{W d}=\frac{(C O f)_{W d}}{\left(D_{e s l}\right)_{W d}}
$$


Obtidos os valores de $(\boldsymbol{\beta})_{W o}$ até $(\boldsymbol{\beta})_{W d}$, é possível criar uma curva de dispersão dos valores de $\boldsymbol{\beta}$ em função do número total de Consumidores Desligados [ $\left(\boldsymbol{D}_{\text {esl }}\right)$ wo até $\left(\boldsymbol{D}_{\text {esl }}\right) \boldsymbol{W d}$ ], de forma a conhecer um padrão comportamental do consumidor. Veja exemplo no gráfico a seguir.

A partir de uma regressão, é possível encontrar a função $f\left(\mathbf{D}_{\text {esl }}\right)$ que melhor representa essa dispersão. Por questões práticas, neste trabalho optou-se por trabalhar com o valor médio dessa função. A linha vermelha do Gráfico 7 representa a média da função $f\left(\mathbf{D}_{\text {esl }}\right)$, média que foi chamada de Fator $\mathbf{P}$, e o intervalo entre a linha rosa e a vermelha o desvio padrão $\boldsymbol{\varphi}$ em relação a média.

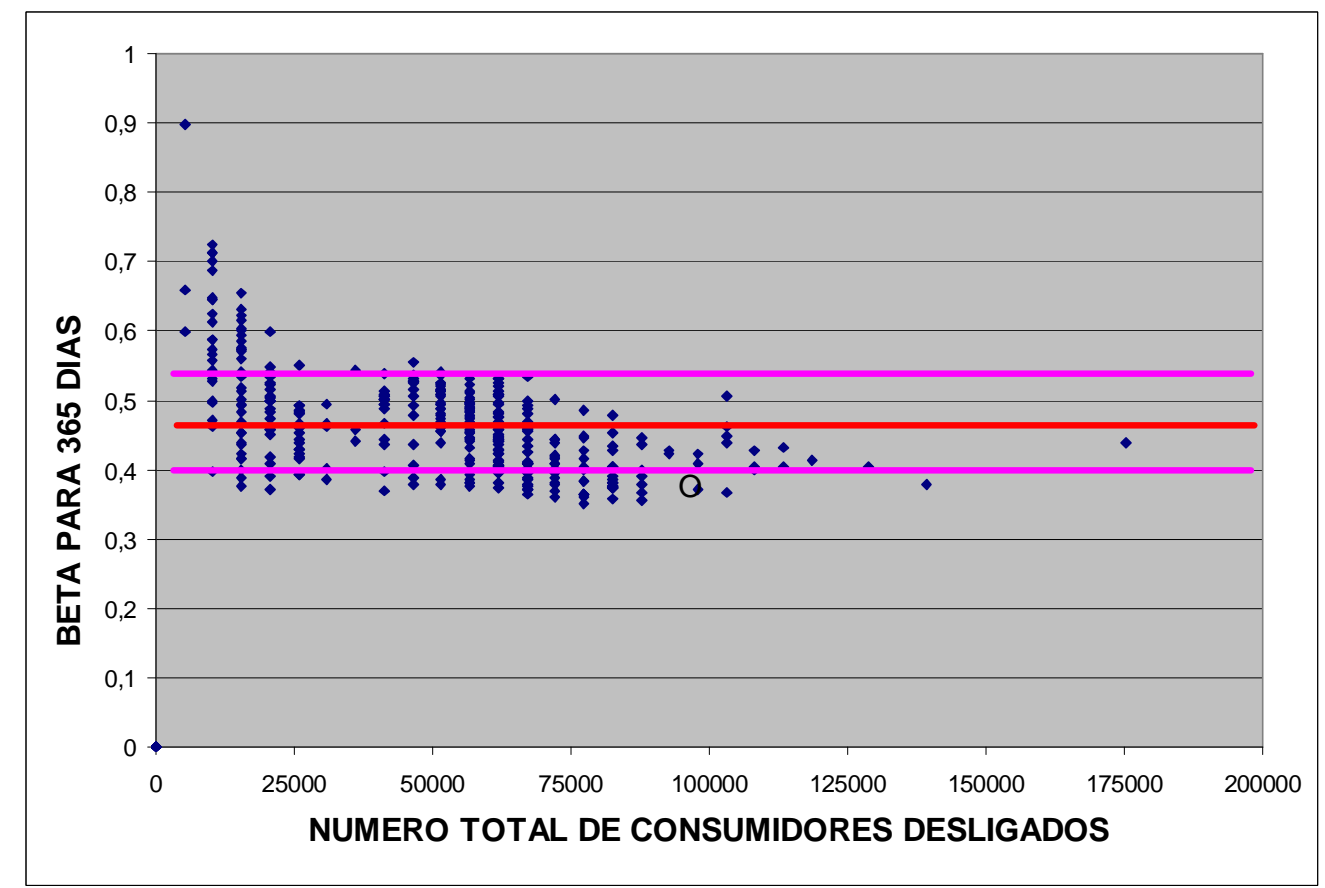

Gráfico 7: Exemplo de curva de dispersão da relação $\beta$ em função do número total de consumidores desligados $\left[D_{\text {esl }}\right]$

\subsection{ENGENHARIA DE TRÁFEGO TELEFÔNICO}

Os resultados quanto a previsão de Chamadas Oferecidas [COf] podem ser aplicados dentro do contexto do Capítulo 7, adotando o modelo a seguir:

\subsubsection{Fonte de Chamadas}

A fonte de chamadas é definida como sendo finita, mas em relação ao sistema de atendimento estudado considera-se na prática como sendo uma fonte infinita, variando entre VE $_{\text {COf. }}$ e $\operatorname{VMax}_{C O f}$. 


\subsubsection{Processo de Chegadas de Chamadas}

Sendo todas as condições satisfeitas para a adoção da Distribuição de Poisson, conforme demonstrou o Estudo de Caso, será considerado que o processo de chegada de chamadas é aleatório. Como hipótese, se propõe que o valor médio da taxa de chegada de chamadas como sendo:

$$
\lambda=\gamma \cdot \frac{V E_{C O f}}{T} \text { [chamadas por minuto] }
$$

onde:

$\boldsymbol{T}$ é o tempo médio em minutos referente período de restauração de circuitos primários interrompidos em situação de emergência apurados no período de 24 meses idêntico ao considerado para o calculo de $\mathbf{V E}_{\mathbf{C O f}}$;

$\gamma \quad$ é um fator de proporcionalidade, positivo, variando normalmente de números a partir de 0,10 até 2,0, podendo ser aproximado pela distribuidora a partir do $\lambda$ e $\boldsymbol{T}$ conhecidos nos dias típicos, dias os quais apresentam um comportamento previsível.

\subsubsection{Processo de Atendimento de Chamadas}

Propõe-se também o processo de atendimento obedece ao padrão aleatório com Distribuição Exponencial negativa, cujo Tempo Médio de Atendimento (TMA), terá um valor adotado baseado na experiência de cada distribuidora.

\subsubsection{Processo de Bloqueio de Chamadas}

Três processos de bloqueio de chamadas devem ser simulados observando as metas definidas para os anos de 2005, 2006, 2007 e 2008 na Resolução № 57 de 2004 da ANEEL:

- Lost Calls Cleared (LCC): Esse modelo admite bloqueio de chamadas excedentes, com uma meta igual ao Índice de Chamadas Ocupadas (ICO) do ano correspondente.

- Lost Calls Retried (LCR): Assume que uma vez bloqueada uma chamada, uma porcentagem dos clientes faz novas tentativas até obter o serviço de atendimento. Propõe-se empiricamente que essa porcentagem de novas tentativas seja igual a meta do Índice de Abandono (IAb) do ano correspondente. 
- Lost Calls Delayed (LCD): As chamadas permanecem em espera até o Tempo Médio de Espera (TME) de 30 segundos, com uma meta igual ao Índice de Nível de Serviços Básico (INB) do ano correspondente.

\subsubsection{Modelos de Tráfego}

Os modelos de tráfego são os Erlang B, Extend Erlang B e Erlang $\mathrm{C}$, e serão calculados usando o programa de computador de Ger Koole da Universidade de Amsterdam. 


\section{APLICAÇÃO DO MÉTODO PROPOSTO}

Os dados aqui mostrados correspondem a CPFL Paulista. O método proposto foi aplicado para essa concessionária.

\subsection{MODELAMENTO ESTATÍSTICO DAS CHAMADAS OFERECIDAS}

10.1.1 Determinação de $D F C I_{E}, E\left(D F C I_{E}\right), \sigma\left(D F C I_{E}\right), V_{M a x} C o f$

\subsubsection{Dados}

Os seguintes dados da concessionária foram considerados:

- $j=1$

- $\quad\left(N C_{m}\right)_{1}=5.000$

- Distribuição Histórica de Freqüências da Quantidade (diária) de Circuitos Interrompidos em Situação de Emergência [ $\boldsymbol{D F C I}_{\boldsymbol{H}}$ ]: Conforme a Tabela 8 e Gráfico 8.

Tabela 8: Distribuição Histórica de Freqüências da Quantidade (diária) de Circuitos Interrompidos em Situação de Emergência [ $D F C I_{H}$ ].

\begin{tabular}{|c|c|c|c|c|c|}
\hline $\mathbf{C I}_{\mathbf{H}}$ & Freqüência & $\mathbf{C I}_{\mathbf{H}}$ & Freqüência & $\mathbf{C I}_{\mathbf{H}}$ & Freqüência \\
\hline 1 & 20 & 13 & 56 & 25 & 2 \\
\hline 2 & 46 & 14 & 40 & 26 & 0 \\
\hline 3 & 66 & 15 & 30 & 27 & 2 \\
\hline 4 & 46 & 16 & 36 & 28 & 0 \\
\hline 5 & 36 & 17 & 14 & 29 & 0 \\
\hline 6 & 10 & 18 & 4 & 30 & 0 \\
\hline 7 & 6 & 19 & 6 & 31 & 0 \\
\hline 8 & 32 & 20 & 10 & 32 & 0 \\
\hline 9 & 28 & 21 & 6 & 33 & 0 \\
\hline 10 & 66 & 22 & 4 & 34 & 2 \\
\hline 11 & 86 & 23 & 2 & & \\
\hline 12 & 88 & 24 & 0 & & \\
\hline
\end{tabular}




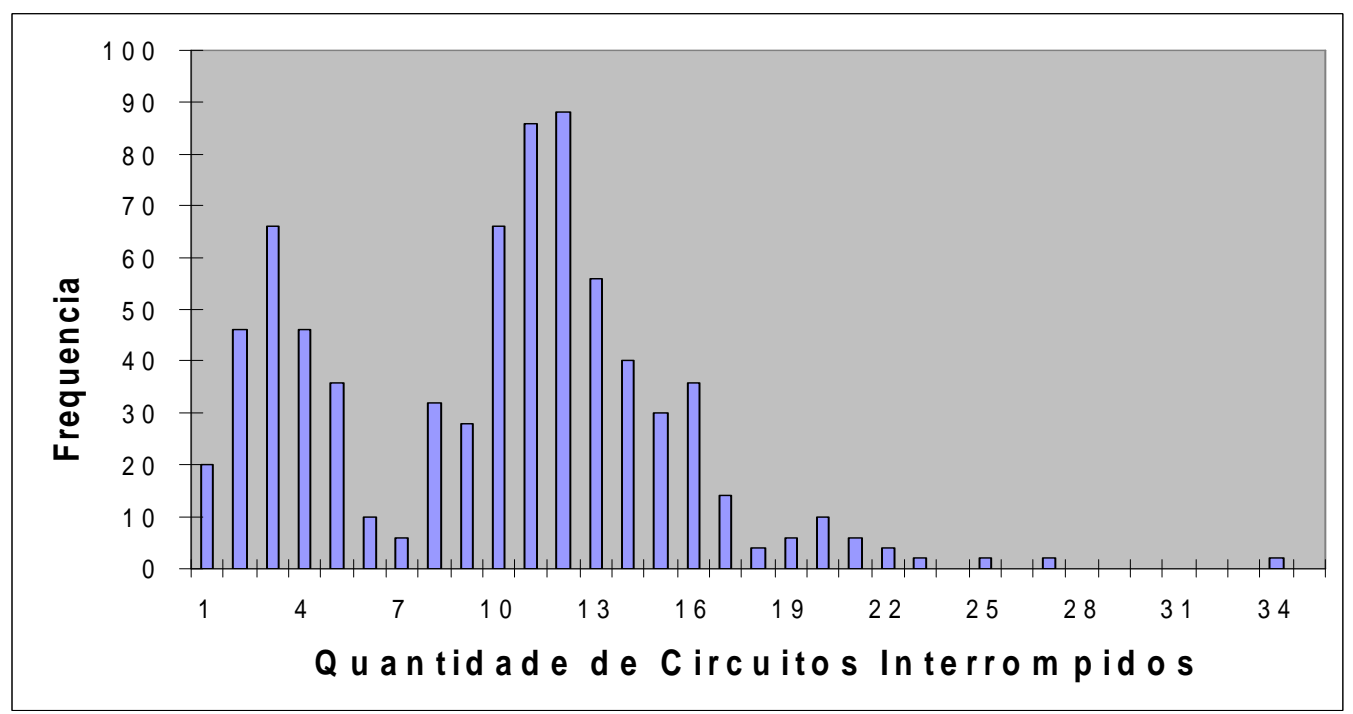

Gráfico 8: Histograma dos dados da Tabela 8.

\subsubsection{Cálculos}

- Escolha de curva ajustada de $D F C I_{H}$ :

Curva Normal, através de ajuste de curvas realizado pelo programa de computador LAB Fit desenvolvido pela Universidade Federal de Campina Grande ${ }^{29}$.

$$
\operatorname{DFCI}_{E}(X)=Y \cdot \frac{1}{\sqrt{2 \pi . \sigma}} \cdot e^{-(1 / 2)\left(\frac{X-E}{\sigma}\right)^{2}}=745 \cdot \frac{1}{\sqrt{2 \pi * 3,2}} \cdot e^{-(1 / 2)\left(\frac{X-11,3}{3,2}\right)^{2}} \cdot
$$

- Distribuição Histórica de Freqüências da Quantidade de Circuitos Interrompidos em Situação de Emergência [ $\boldsymbol{D F C I _ { E }}$ ]: Conforme Gráfico 9.

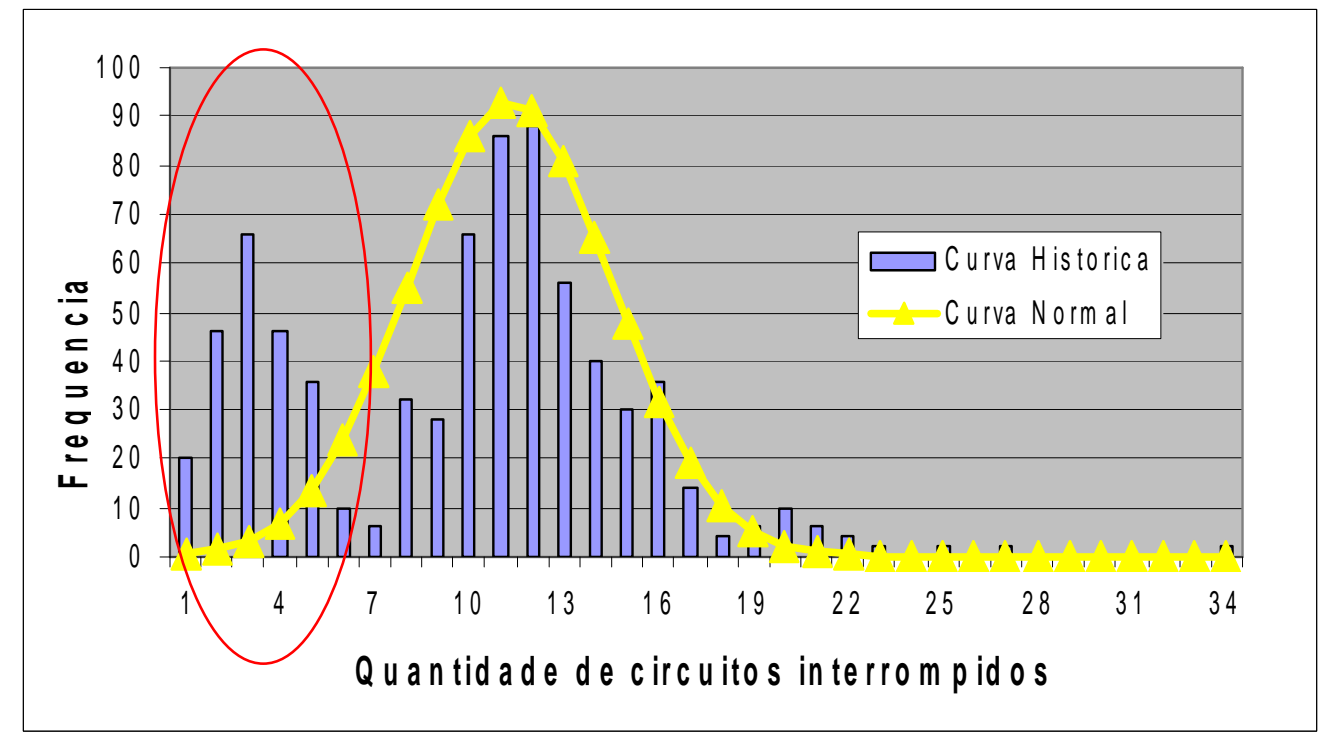

Gráfico 9: Curva Normal DFCI ${ }_{E}$ comparando com Curva Histórica DFCI $_{H}$

\footnotetext{
${ }^{29}$ O programa LAB Fit está disponível em <http://zeus.df.ufcg.edu.br/labfit/index.htm>.
} 
No Gráfico 9 nota-se duas curvas semelhantes a Normal, uma menor (a esquerda, destacado em vermelho) e uma maior (no centro). Neste ajuste em específico optou-se por considerar e dar mais importância as interrupções de grande abrangência, ou seja, os dados da Curva Normal com maior quantidade de circuito interrompidos.

- $E\left(\operatorname{DFCI}_{E}\right)=11,3 \quad \sigma\left(\operatorname{DFCI}_{E}\right)=3,2$

- $\sum_{i=1}^{j}\left[E_{\left(D Q C I_{C}\right)}+3 \cdot \sigma_{\left(D Q C I_{C}\right)}\right]_{i}=\sum_{i=1}^{1}[11,3+3 \cdot 3,2]_{1}=20,9 \cong 21$

O valor 21 representa que a suposição que todos os dias que tiverem 21 ou mais circuitos interrompidos em situação de emergência serão considerados Dias Críticos. Sendo assim, de acordo com os dados históricos, nos últimos 24 meses ocorreram 18 Dias Críticos.

- $\operatorname{VMax}_{C O f}=\sum_{i=1}^{j}\left[E_{\left(D Q C I_{C}\right)}+3 \cdot \sigma_{\left(D Q C I_{C}\right)}\right]_{i}\left(N C_{m}\right)_{i}=21 \cdot 5000=105.000$

\subsubsection{Determinação do Fator P e $\varphi$}

\subsubsection{Dados}

- $\boldsymbol{W}_{\boldsymbol{d}}=365$ dias.

- Quantidade total diária de Circuitos Interrompidos em situação de emergência [CI $\mathbf{I}_{\mathrm{H}}$, apurado no período de 12 meses: Ver APÊNDICE A.

- Chamadas Atendidas [ CA ], apurado no período de 12 meses: Ver APÊNDICE B.

- Índice de Chamadas Ocupadas [ ICO ], apurado no período de 12 meses: Ver APÊNDICE C.

\subsubsection{Cálculos}

- Consumidores Desligados [ $\left(\boldsymbol{D}_{e s l) W_{0} a t e ́(}\left(\boldsymbol{D}_{e s l) W_{d}}\right]\right.$ : Ver APÊNDICE D.

$$
\left(D_{e s l}\right)_{W}=\sum_{i=1}^{j}\left\{\left(N C_{m}\right)_{i} \cdot\left[\left(C I_{H}\right)_{W}\right]_{i}\right\}=\sum_{i=1}^{1}\left\{(5000)_{i} \cdot\left[\left(C I_{H}\right)_{W}\right]_{1}\right\}
$$

- $\Sigma D_{\text {esl }}=18.255 .000$, de $W_{0}$ até $W_{d}$. 
- Chamadas Oferecidas [ $(\text { COf })_{\mathrm{w}_{\mathbf{0}}}$ até $\left.(\mathbf{C O f})_{\mathrm{w}_{\mathbf{d}}}\right]$ : Ver APÊNDICE E.

$$
(C O f)_{W}=(C A)_{W} \cdot \frac{1}{1-(I C O)_{W}}
$$

- Relação $\boldsymbol{\beta}$ : Ver APÊNDICE F.

$$
(\beta)_{W}=\frac{(C O f)_{W}}{\left(D_{e s l}\right)_{W}}
$$

- Dispersão e Regressão de $\beta$ : Conforme Gráfico 10.

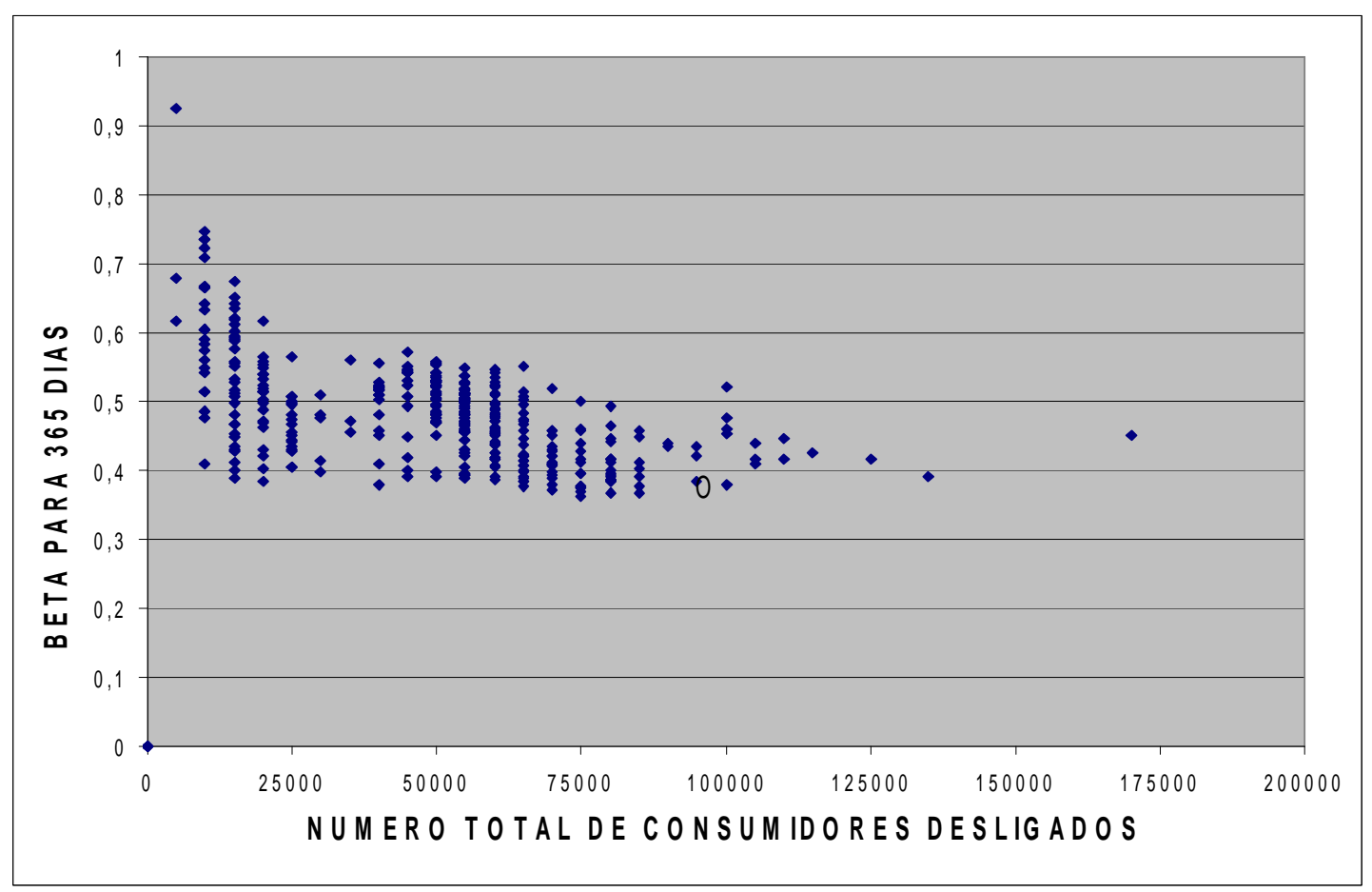

Gráfico 10: Gráfico de Dispersão de $\beta$

É possível obter a média da função que melhor representa a variável $\boldsymbol{\beta}$. O Fator $\mathbf{P}$ é a média da dispersão, e $\varphi$ é desvio padrão em relação a média.

- $\quad$ Fator $P=0,4803$ e $\varphi=0,0755$ 


\subsubsection{Determinação de $\mathrm{VMed}_{\mathrm{COf}}$ e $\mathrm{VE}_{\mathrm{COf}}$}

\subsubsection{Dados}

- $\operatorname{VMax}_{\text {COf }}=105.000$

- Fator $\mathrm{P}=0,4803$ e $\varphi=0,0755$

\subsubsection{Cálculos}

- $\quad \operatorname{VMed}_{\text {COf }}=\mathrm{P} \cdot \operatorname{VMax}_{\mathrm{COf}}=0,4803 \cdot 105000=50.433$

- $\operatorname{Para} q=1$ =>

Limite superior de $V E_{C O f}=(\mathrm{P}+q \cdot \varphi) \cdot \operatorname{VMax}_{C O f}=$ $=(0,4803+1 \cdot 0,0755) \cdot 105000=58.360$

Limite inferior de $V E_{C O f}=(\mathrm{P}-q \cdot \varphi) \cdot \operatorname{VMax}_{C O f}=$ $=(0,4803-1 \cdot 0,0755) \cdot 105.000=42.505$

- $\operatorname{Para} q=2=>$

Limite superior de $V E_{C O f}=(\mathrm{P}+q \cdot \varphi) \cdot \operatorname{VMax}_{C O f}=$ $=(0,4803+2 \cdot 0,0755) \cdot 105000=66.288$

Limite inferior de $V E_{C O f}=(\mathrm{P}-q \cdot \varphi) \cdot \operatorname{VMax}_{C O f}=$ $=(0,4803-2 \cdot 0,0755) \cdot 105000=34.577$

- $\quad$ Para $q=3$ =>

Limite superior de $V E_{C O f}=(\mathrm{P}+q \cdot \varphi) \cdot \operatorname{VMax}_{C O f}=$ $=(0,4803+3 \cdot 0,0755) \cdot 105000=74.215$

Limite inferior de $V E_{C O f}=(\mathrm{P}-q \cdot \varphi) \cdot V M a x_{C O f}=$ $=(0,4803-3 \cdot 0,0755) \cdot 105000=26.650$ 


\subsubsection{Resumo dos Resultados}

VMed $_{\text {Cof }}=\mathbf{5 0 . 4 3 3}$ chamadas em um Dia Crítico.

Para $\boldsymbol{q}=1$, Limite Superior de $\mathrm{VE}_{\mathrm{COf}}=58.360$ chamadas;

Para $\boldsymbol{q}=2$, Limite Superior de $\mathrm{VE}_{\mathrm{COf}}=66.288$ chamadas;

Para $\boldsymbol{q}=3$, Limite Superior de $\mathrm{VE}_{\mathrm{COf}}=74.215$ chamadas.

Para comparativo entre os cenários e resultados, veja Gráfico 11.

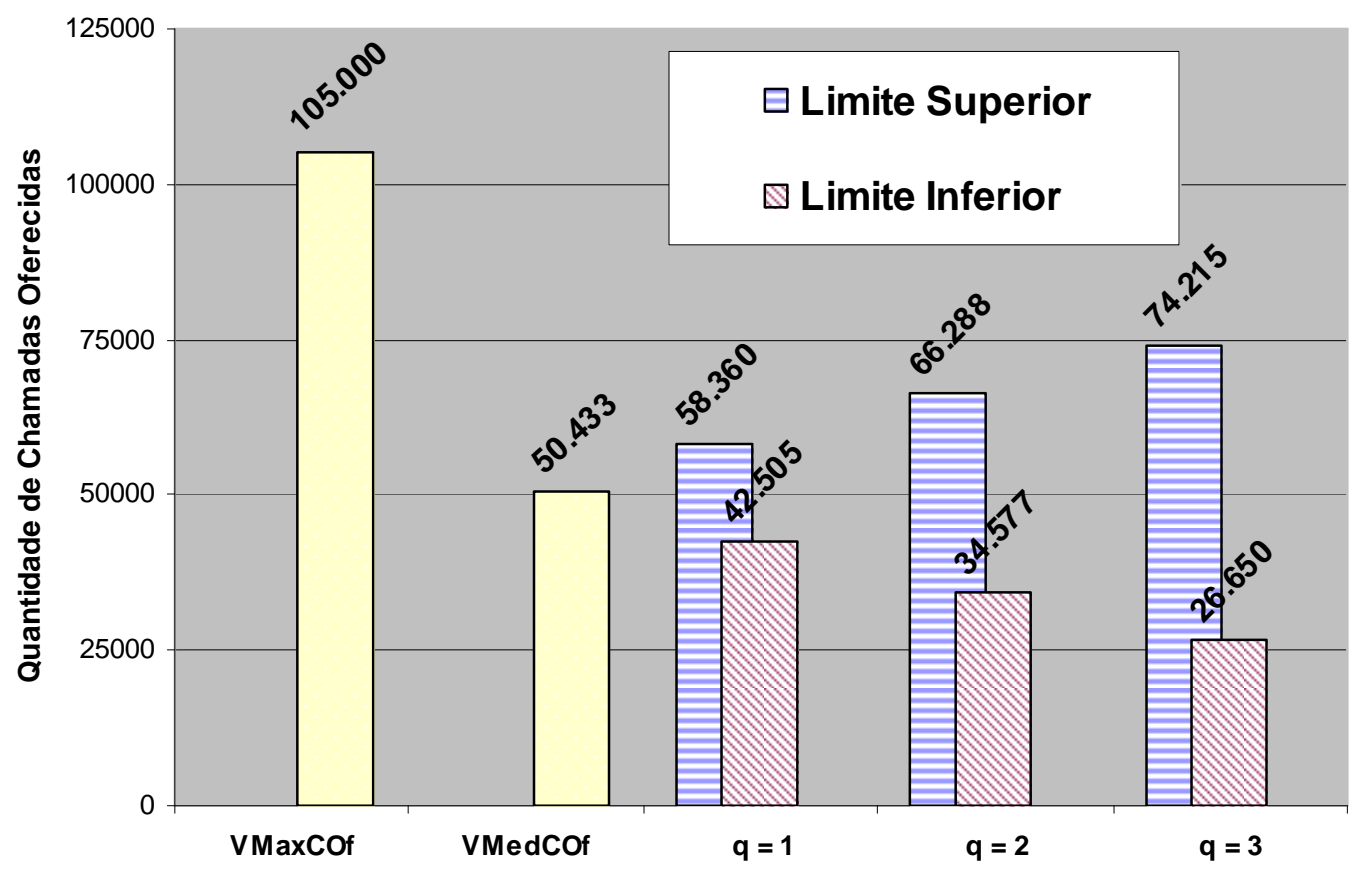

Gráfico 11: Comparativo da previsão de Quantidade de Chamadas Oferecidas (COf) em um Dia Crítico para cinco cenários diferentes.

Analisando um Histograma (de freqüências) cumulativo da Dispersão de $\boldsymbol{\beta}$, obtém-se que para:

$\boldsymbol{q}=1$, representa-se $90 \%$ dos Dias Críticos;

$\boldsymbol{q}=2$, representa-se $96 \%$ dos Dias Críticos;

$\boldsymbol{q}=3$, representa-se $99 \%$ dos Dias Críticos.

Mas, ao ser avaliado especificamente os valores da Dispersão de $\boldsymbol{\beta}$ para o caso estudado, conclui-se que a maioria dos Dias Críticos está com valores próximos da média desses dias. Logo, adota-se de forma não conservativa o limite superior de $q=1\left(\mathbf{V E}_{\mathbf{C o f}}=\right.$ $\mathbf{5 8 . 3 6 0})$, e de forma conservativa o limite superior de $q=3\left(\mathbf{V E}_{\mathbf{C o f}}=\mathbf{7 4 . 2 1 5}\right)$. 


\subsection{ENGENHARIA DE TRÁFEGO TELEFÔNICO}

Os resultados de 9.1.4 foram ponderados dentro do contexto do item 8.5 deste trabalho e da Resolução № $57 / 2004$ da ANEEL.

\subsubsection{Dados}

- Conforme Tabela 9.

Tabela 9: Resumo dos Dados para Cálculos de Engenharia de Tráfego.

\begin{tabular}{|c|c|c|}
\hline DADOS & VALOR & UNIDADE \\
\hline Fonte de Chamadas $=\mathbf{V E}_{\mathbf{C O f}}(\mathbf{q}=\mathbf{1})$ & 58.360 & chamadas por dia \\
\hline $\mathbf{T}$ & 420 & minutos \\
\hline $\boldsymbol{\gamma}$ & 0,6667 & adimensional \\
\hline Tempo Médio de Atendimento (TMA) & 120 & segundos \\
\hline Tempo Médio de Espera (TME) & 30 & segundos \\
\hline
\end{tabular}

\subsubsection{Cálculos e Tabela de Resultados}

- $\lambda=93$ chamadas por minuto;

- $\mu=1 / 120$ segundos;

- $\rho=185$ Erlangs.

Tabela 10: Resultados de Engenharia de Tráfego de Acordo com os Modelos Adotados

\begin{tabular}{|c|c|c|c|c|}
\hline \multirow{5}{*}{ Erlang B } & $\begin{array}{l}\text { Metas do Ano } \\
\text { da ANEEL }\end{array}$ & ICO & $\begin{array}{c}\text { Linhas } \\
\text { Telefonicas }(k)\end{array}$ & \\
\hline & 2005 & $15 \%$ & 163 & \\
\hline & 2006 & $10 \%$ & 174 & \\
\hline & 2007 & $7 \%$ & 182 & \\
\hline & 2008 & $4 \%$ & 191 & \\
\hline \multirow{9}{*}{$\begin{array}{l}\text { Extended } \\
\text { Erlang B }\end{array}$} & $\begin{array}{l}\text { Metas do Ano } \\
\text { da ANEEL }\end{array}$ & ICO & IAb & $\begin{array}{c}\text { Linhas } \\
\text { Telefonicas }(k)\end{array}$ \\
\hline & 2005 & $15 \%$ & $24 \%$ & 169 \\
\hline & 2006 & $10 \%$ & $24 \%$ & 178 \\
\hline & 2007 & $7 \%$ & $24 \%$ & 185 \\
\hline & 2008 & $4 \%$ & $24 \%$ & 193 \\
\hline & 2005 & $15 \%$ & $4 \%$ & 164 \\
\hline & 2006 & $10 \%$ & $4 \%$ & 175 \\
\hline & 2007 & $7 \%$ & $4 \%$ & 182 \\
\hline & 2008 & $4 \%$ & $4 \%$ & 191 \\
\hline \multirow{5}{*}{ Erlang C } & $\begin{array}{l}\text { Metas do Ano } \\
\text { da ANEEL }\end{array}$ & INB & $\begin{array}{c}\text { TME } \\
\text { (segundos) }\end{array}$ & $\begin{array}{c}\text { Posiçõos de } \\
\text { Atendimento }(\alpha)\end{array}$ \\
\hline & 2005 & $80 \%$ & 30 & 190 \\
\hline & 2006 & $85 \%$ & 30 & 191 \\
\hline & 2007 & $90 \%$ & 30 & 192 \\
\hline & 2008 & $95 \%$ & 30 & 194 \\
\hline
\end{tabular}




\section{DISCUSSÃO DOS RESULTADOS}

\subsection{VALIDAÇÃO DO MODELAMENTO ESTATÍSTICO DAS CHAMADAS OFERECIDAS}

Um modo encontrado de validar o modelo genérico é a partir dos resultados particulares do item 10.1.4, comparando a quantidade histórica de Chamadas Atendidas nos Dias Críticos (ou seja, dias que apresentaram 21 ou mais circuitos primários interrompidos) da concessionária estudada com o valor calculado de $\mathbf{V E}_{\mathbf{C o f}}$. Como dado histórico de $\mathbf{V E}_{\mathbf{C O}}$ da CPFL Paulista, apurado entre Out/2004 e Set/2005, têm-se a Tabela 11:

Tabela 11: Dados Históricos de Quantidade de Chamadas Atendidas em Dias Críticos pela Concessionária Estudada

\begin{tabular}{|c|c|c|c|c|}
\cline { 2 - 5 } \multicolumn{1}{c|}{} & $\mathbf{2 0 0 4}$ & \multicolumn{3}{c|}{2005} \\
\hline DIA & OUT & JAN & MAI & SET \\
\hline 4 & & 46.540 & & \\
\hline 5 & & 43.435 & & 65.192 \\
\hline 7 & & 46.615 & & \\
\hline 13 & & & 41.498 & \\
\hline 18 & 43.900 & & & \\
\hline 25 & & & 49.464 & \\
\hline
\end{tabular}

A média dos valores da tabela acima é 48.092, valor próximo do valor calculado para VMed $_{\text {Cof }}=\mathbf{5 0 . 4 3 3}$ (item 10.1.3.2), tendo a considerar ainda que o valor médio histórico de 48.092 são de Chamadas Atendidas efetivamente e não de Chamadas Oferecidas, o que significa que não inclui as Chamadas Ocupadas. A média anual de Chamadas Ocupadas na CPFL Paulista está em torno de $6 \%$ a $7 \%$.

Logo, é possível considerar o modelo estatístico válido, e possível de generalização para outras distribuidoras de energia elétrica.

\subsection{ENGENHARIA DE TRÁFEGO TELEFÔNICO}

\subsubsection{Discussão dos Resultados}

Nota-se na Tabela 10 que os resultados dos modelos Erlang B e Extend Erlang B pouco diferem entre si. 
Em uma análise menos conservativa dos resultados da Tabela 10, adota-se como resultado final as metas de atendimento do ano 2005 da ANEEL. Dessa forma, os cálculos indicaram a necessidade de um PABX com no mínimo 169 linhas telefônicas e 190 Posições de Atendimento. Em uma análise mais conservativa, adota-se como resultado as metas do ano 2008 da ANEEL. Dessa forma, os cálculos indicaram a necessidade de um PABX com no mínimo 193 linhas telefônicas e 194 Posições de Atendimento.

A grandeza desses números difere de dados reais da concessionária, que possui 90 Posições de Atendimento para a região de concessão estudada, o que significa que a concessionária deverá prover meios de comunicação e mídias alternativas de atendimento aos consumidores visando a demanda de ligações para a Central de Teleatendimento (se desejar manter-se pelo menos próxima das métricas de Qualidade de Serviço definidas pela ANEEL para os Dias Típicos), pois somente com o atendimento humano de 90 Posições de Atendimento irá prover um Índice de Nível de Serviço Básico (INB) inferior a $10 \%$.

$\mathrm{Na}$ verdade, a CPFL já possui uma URA (conforme descrito na página 74) com dezenas de canais de atendimento automático, canais estes que somados a quantidade de PAs humanas, constituem número total próximo da quantidade requisitadas pela análise mais conservativa da engenharia de tráfego, revelando que grande parte de seus consumidores nos Dias Críticos conseguem acesso à CTA.

Ou seja, mesmo optando por manter a quantidade de Posições de Atendimento atuais, o método pode indicar com precisão para as distribuidoras a quantidade necessária de canais de mídia alternativos (URA, por exemplo) visando atender a demanda dos Dias Críticos.

\subsubsection{Validação da Equação (22)}

Para validar a Equação (22), relativa a taxa média de chegada de chamadas, e $\mathbf{T}=\mathbf{4 2 0}$ minutos, será ensaiado o modelo de tráfego Erlang $C$ para os Dias Típicos mantendo todas as demais variáveis inalteradas:

$$
\begin{aligned}
& \operatorname{VMax}_{\text {COf DIAS TIPICOS }}=\sum_{i=1}^{j}\left[E_{\left(D Q C I_{C}\right)}\right]_{i} \cdot\left(N C_{m}\right)_{i} \\
& \operatorname{VMax}_{\text {COf DIAS TIPICOS }}=11,3 \cdot 5000=56.500 \\
& \operatorname{VMed}_{\text {COf DIAS TIPICOS }}=\mathrm{P} \cdot \operatorname{VMax}_{\text {COf DIAS TIPICOS }} \\
& \text { VMed }_{\text {COf DIAS TIPICOS }}=0,4803 \cdot 56.500=27.137
\end{aligned}
$$


A partir de VMed $_{\text {Cof }}$ DIAS TIPICOS $=\mathbf{2 7 . 1 3 7}$, constrói-se a Tabela 12:

Tabela 12: Cálculo de Posições de Atendimento Para Dias Típicos

\begin{tabular}{|c|c|c|c|c|c|c|}
\hline & $\begin{array}{c}\text { Metas do } \\
\text { Ano da } \\
\text { ANEEL }\end{array}$ & $\begin{array}{c}\text { VE }_{\text {Cof }} \\
\text { (chamadas } \\
\text { por dia) }\end{array}$ & INB & $\begin{array}{c}\text { TMA } \\
\text { (segundos) }\end{array}$ & $\begin{array}{c}\text { TME } \\
\text { (segundos) }\end{array}$ & $\begin{array}{c}\text { Posições de } \\
\text { Atendimento } \\
\boldsymbol{\alpha}\end{array}$ \\
\cline { 2 - 7 } Erlang C & 2005 & 27.137 & $80 \%$ & 120 & 30 & 91 \\
\cline { 2 - 7 } & 2006 & 27.137 & $85 \%$ & 120 & 30 & 92 \\
\cline { 2 - 7 } & 2007 & 27.137 & $90 \%$ & 120 & 30 & 93 \\
\cline { 2 - 7 } & 2008 & 27.137 & $95 \%$ & 120 & 30 & 95 \\
\hline
\end{tabular}

Os números da última coluna da tabela acima são muito semelhantes com as $\mathbf{9 0}$ Posições de Atendimento da concessionária estudada, validando assim a Equação (22).

\subsubsection{Análise de Sensibilidade}

A relação porcentual entre $\mathbf{V E}_{\mathbf{C O f}}=\mathbf{5 8 . 3 6 0}($ para $q=1)$ e $\mathbf{V E}_{\mathbf{C O f}}=\mathbf{7 4 . 2 1 5}($ para $q=$ 3) é de $27 \%$, e outras simulações indicam que os resultados da Tabela 10 também crescem próxima dessa porcentagem quando é adotado $\mathbf{V E}_{\mathbf{C O f}}=\mathbf{7 4 . 2 1 5}$, o que indica certa linearidade nessa parte do dimensionamento do tráfego telefônico.

Verifica-se ainda que os resultados são sensíveis ao Tempo Médio de Atendimento (TMA). Se o TMA for aumentado de 120 segundos para 180 segundos (50\%), ocorre um acréscimo também da ordem de 50\% na quantidade de Posições de Atendimento necessárias. O mesmo não acontece em relação ao Tempo Médio de Espera (TME). Se for aumentado de 30 segundos para 150 segundos (500\%) o TME, será reduzida a quantidade de Posições Necessárias na ordem de 5\%.

Essa análise indica uma estratégia de atendimento para a concessionária para aumento virtual da capacidade: acelerar o atendimento e assim diminuir a duração da conversação. 


\section{CONSIDERAÇÕES FINAIS}

\subsection{RECOMENDAÇÕES}

Os números anteriormente demonstrados reforçam a tese sobre a necessidade de serem implantados outros serviços e mídias alternativas para atendimento ao consumidor nos Dias Críticos. Tese que acarreta na resposta de uma questão fundamental: qual é o meio de comunicação mais adequado para manter informado o maior número de consumidores possíveis numa situação de desligamento em massa? Diversas tecnologias de comunicação foram apresentadas no Capítulo 6, mas uma única resposta para esta pergunta não existe. A estratégia mais completa de escolha de veículos de comunicação deve abranger mídias diferenciadas por consumidor, tanto receptivas quanto ativas. Devem ser receptivas e ativas devido a necessidade de interatividade que o processo exige. Mídias de maior abrangência e maior penetração devem ser combinadas com mídias de penetração a públicos mais restritos.

Empregando o método de qualificação presente no item 7.2, na Tabela 13 (página seguinte) há uma lista considerando as tecnologias discriminadas no Capítulo 6, lista essa propondo qual deve ser a prioridade de implantação dos novos serviços de atendimento pelas concessionárias de distribuição de energia elétrica. Entre os critérios para estabelecer essas prioridades (Altíssima, Alta, Média e Baixa) estão em dar preferência para serviços da classe Auto Service, que atendem o público Geral, e de Ampla Penetração.

Ou seja, ao estabelecer prioridades de investimentos na implantação de novos sistemas de comunicação, a distribuidora deverá apresentar preferências pelas aquelas que atingem um maior público, que tem uma maior penetração e que prestam um serviço de menor interação com os atendentes humanos. É certa a conclusão que os meios de comunicação que visem atender o público em massa devem considerar a convergência da telefonia móvel como o meio de mais ampla abrangência e penetração.

A distribuidora poderá ainda aprimorar seus sistemas de comunicação para as interrupções de emergência, mas para isso exigindo do consumidor pagamento de taxa de serviço extra pela informação adicional transmitida via canal de comunicação não convencional, como por exemplo via SMS. Como a obrigatoriedade desse serviço ainda não é regulada, as distribuidoras podem fazer essa cobrança para o consumidor que requisitar o serviço diferenciado. $\mathrm{O}$ valor arrecadado pode ser reinvestido na melhoria dos sistemas de comunicação como um todo. 


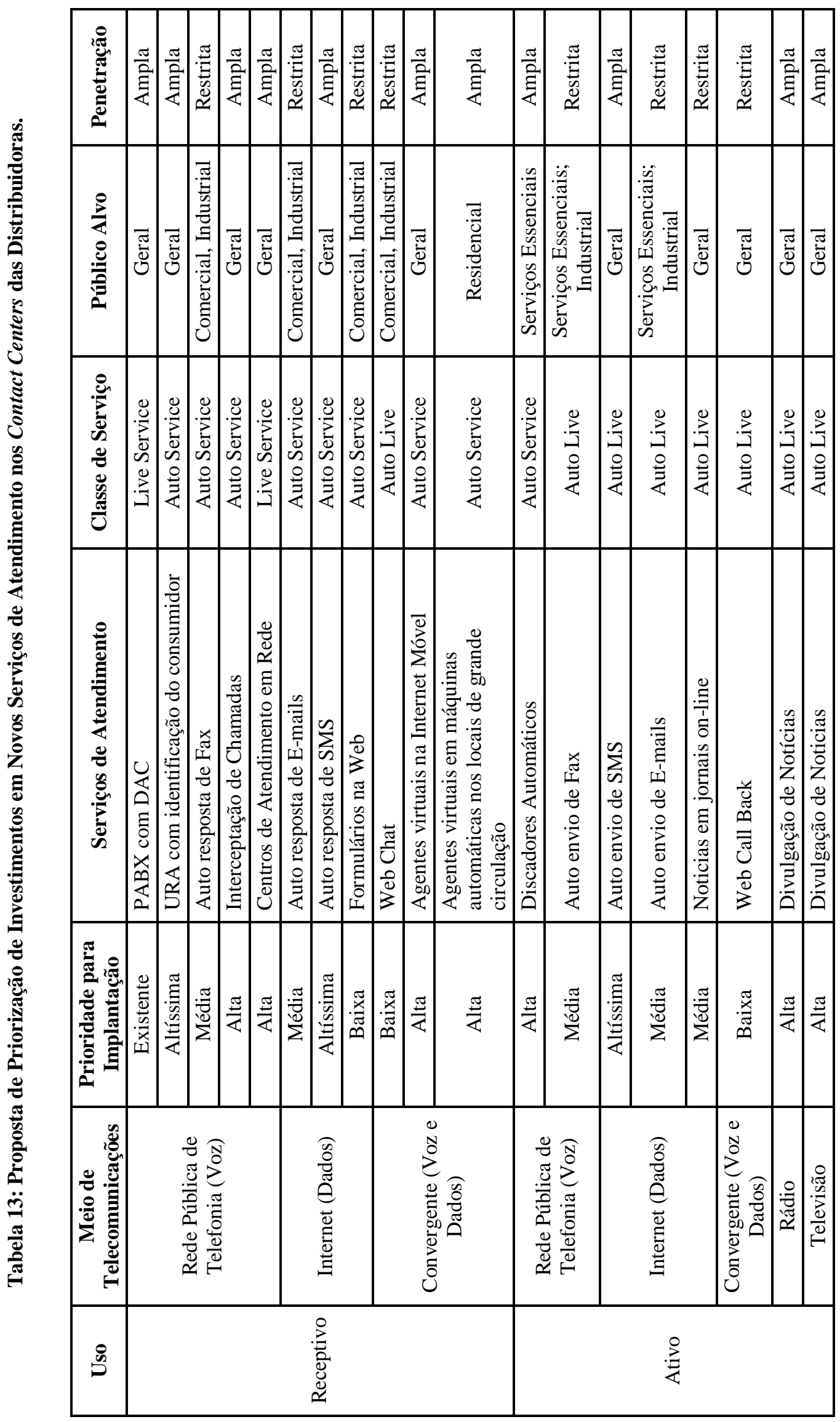


Todavia, a experiência adquirida por cada concessionária é de vital importância para definir a solução do problema de relacionamento em tempo real com o consumidor, pois o perfil dos consumidores também varia de acordo com a região de concessão. Ou seja, cada concessionária deve buscar conhecer seus consumidores. Para tanto há modernas técnicas de Marketing entre elas o Marketing One to One, citado neste trabalho. No caso dos grandes consumidores, os clientes corporativos (de média ou alta tensão) ou prestadores de serviços especiais, a melhor alternativa é criar um contact center específico, de forma a diferenciá-los do mercado de massa. Dessa forma, tais consumidores poderão ter acessos às informações de forma mais ágil, além de um tratamento mais especializado, criando inclusive um diferencial competitivo no mercado livre de energia.

Cada concessionária deve também adotar uma forte política de atualização de dados de contato sobre os consumidores, pois tais dados são tão significativos quanto a tecnologia de informação em si. É imperativo que as distribuidoras criem estratégias (considerando até estímulos econômicos) que incitem os clientes a manterem os seus cadastros atualizados,

como número de telefone residencial, comercial, celular, fax, endereço de e-mail, CEP, etc.. É notório que hoje no Brasil existe um alto índice de troca de número de aparelho celular por conta da grande concorrência entre as concessionárias de telefonia. É também interessante que as distribuidoras começassem a identificar no seu cadastro algumas funcionalidades do aparelho celular de seus clientes, ou seja, se estes celulares suportam o tipo de formato de mensagens que serão encaminhadas.

\subsection{CONCLUSÕES}

Relacionar-se, satisfazer as expectativas e interagir: essas serão tarefas inadiáveis dos prestadores de serviços públicos, em especial os de energia elétrica, tendo em vista o valor que esta atividade representa em termos econômicos e sociais. A comunicação em tempo real, a divulgação de informação em grande escala, a rapidez com que elas são absorvidas, e a amplitude com que atingem o público serão preocupações crescentes das distribuidoras de energia elétrica e do órgão regulador.

Comparando-se com outros setores da atividade econômica, há bastante espaço para melhora da comunicação das distribuidoras com o seu público externo e ou consumidor. Mas não faltam barreiras. Uma dessas dificuldades é que o fato que comunicação de massa em tempo real é, sobretudo, uma comunicação dirigida a um público vasto, heterogêneo e anônimo - diferentemente da comunicação pessoal, a qual o comunicador conta com imediato e contínuo feedback da audiência. 
A análise dos resultados do Capítulo 10 conduz para a primeira importante conclusão: é improvável a existência, na prática, de uma Central de Teleatendimento, em uma distribuidora de energia elétrica, que atenda com uma alta qualidade de serviço os consumidores nos Dias Críticos somente utilizando os expedientes tradicionais. Tal conclusão deve-se principalmente aos investimentos necessários para tal instalação, e também aos altos custos mensais com manutenção de equipamentos e recursos humanos.

Ao longo da dissertação foi destacado o papel do moderno contact center na solução dos problemas apontados. O contact center será o núcleo de interação com os clientes, e o moderno contact center deve considerar os paradigmas citados nesta pesquisa, criando uma estratégia nesse contexto da expectativa do consumidor de amanhã quanto à convergência, mobilidade, e alta disponibilidade de informação em tempo real. E uma das variáveis desta equação, conforme demonstrou o Capítulo 6, é infra-estrutura tecnológica.

Quanto aos aspectos legais, conforme o Capítulo 4 evidenciou, houve grande evolução da questão do direito de informação do consumidor de energia elétrica, principalmente com o advento da Lei Federal № 8.078, da Resolução № 27 e da Resolução № 57 da ANEEL. Mas considerando que a ANEEL tem poderes para normatizar o assunto, ainda não ocorreu a completa legitimação da salvaguarda do direito de informação do consumidor nos casos de interrupções de emergência em Dias Críticos. Este tipo de desligamento exige outros processos de comunicação e metas de atendimento diversas das existentes.

Ao analisar o Estado da Arte e demais contextos desta pesquisa, concluí-se que em termos práticos as recomendações da OFREG descritas no Capítulo 3 são grandes desafios. Mas a Northern Ireland Eletricity (NIE) implantou essas recomendações, e obteve excelente resultados. O fato que é a solução destes desafios certamente passa por novos sistemas informatizados capazes de:

- Receber informações dos consumidores através de diferentes meios e mídias, tendo em vista desafogar os centros de atendimento telefônicos tradicionais, e que estas informações possam ser inseridas na plataforma de gerência de rede elétrica;

- Automatizar a tomada de decisões, avaliando diversas variáveis (como o tipo de desligamento, tipo de consumidor, cadastro de clientes, duração da interrupção, horário da interrupção, etc.);

- Iniciar comunicação com consumidor sobre o tempo de restauro de seu circuito, utilizando diversas mídias sem interação humana, controlando os sucessos e insucessos e novas tentativas de contato e aviso. 
Historicamente, as empresas em geral têm escolhido seus fornecedores de sistemas informatizados entre aqueles que detêm o estado da arte da tecnologia; todavia ressalta-se que em geral tais sistemas não são conectados entre si, revelando pouca estratégia de tecnologia de informação, o que abre espaço para o aprimoramento da organização interna, que por sua vez levaria a unificar alguns projetos. Isto deve ser evitado, e neste trabalho foram identificadas modernas técnicas de gestão de tecnologia que auxiliam nesta tarefa, bem como questões relativas à segurança e garantia da disponibilidade da informação.

\subsection{SUGESTÕES PARA NOVAS PESQUISAS}

Dentro do contexto analisado na presente dissertação, ocorreu a desconsideração de certos aspectos do problema descrito em 2.1. Isto se deu visando obter uma primeira solução, ou quando o detalhamento demasiado fugia dos objetivos da pesquisa. Novos trabalhos podem ser feitos na luz desses detalhes. Além disso, alguns outros contextos do problema não foram indicados, e poderiam ser mais bem explorados. São eles:

\subsubsection{Modelamento das Chamadas Oferecidas}

- Conforme o item 9.3.1, poderia ser introduzida completamente a variável Tempo de Restauração, pois neste trabalho admite-se que todos os desligamentos seriam resolvidos dentro do período de até um dia após a ocorrência, não importando encadeamento individual dos eventos de interrupção ou a sequiência da resolução dos problemas. Mas à medida que o tempo de interrupção aumenta, ou dependendo da correlação dos circuitos primários interrompidos, um maior número de consumidores tende a ligar para a Central de Teleatendimento visando informações atualizadas, o que levará a uma falha do modelo de quantidade de Chamadas Oferecidas;

- Execução de um software para ser usado pelas concessionárias da distribuição, constituído dos métodos apresentados no Capítulo 9;

- Modelamento alternativo do método proposto no Capítulo 9 através de técnicas de inteligência artificial.

\subsubsection{Contexto Econômico}

Neste contexto, algumas óticas podem ser traçadas e merecem tratamento futuro: 
- Não raro, depois de esperar um longo período em uma linha tipo "ligação gratuita", o consumidor abandona a chamada telefônica, acarretando custo dobrado pela concessionária, pois certamente uma parcela destes consumidores irá tentar contatar a empresa novamente. Esse fato econômico motiva a renovação de tecnologias e de processos, além da procura de outras mídias menos onerosas às distribuidoras em Dias Críticos tendo em vista o Retorno do Investimento;

- Já que a instalação das tecnologias descritas no Capítulo 6 certamente exigem investimentos, é possível que tenha boa relação custo benefício a diminuição dos riscos de interrupção de emergência na rede primária, evitando a demanda de chamadas para a Central de Teleatendimento. Esse risco pode ser diminuído, por exemplo, com a automatização da rede, substituindo cabos antigos por mais modernos, tornando a rede subterrânea, ou mesmo construindo circuitos alternativos redundantes. Há certos circuitos primários mais deficitários, com maior índice de falhas, e estes poderiam ter investimento priorizado. Esse tipo de análise precisa comparar os preços de cada instalação, e exige levantamentos minuciosos de custos, tanto da tecnologia de informação quando das técnicas de melhoria da rede primária.

- Considerando que a informação sobre a duração da interrupção de emergência pode trazer benefícios de ordem econômica para o consumidor (que poderia tomar mediadas pró-ativas de resgatar alimentos de congeladores, antecipar ou adiar trabalhos, etc..), pesquisas podem ser realizadas para apurar o custo para a sociedade da eventual desinformação. Esse custo para a sociedade pode ser comparado em termos unitários com o montante de investimento necessário para acrescer um canal de comunicação (posições de atendimento, ou canais de URA, por exemplo) nas Centrais de Teleatendimento;

\subsubsection{Contexto da Gerência de Falhas}

Podem ser estudadas as modernas técnicas de detecção das falhas nos circuitos da rede de distribuição, pois quanto mais rápida e exata essa detecção, mais precisa será a informação dada ao consumidor, e mais rápida a restauração dos circuitos interrompidos, o que por sua vez diminuíra o volume de chamadas esperadas na Central de Teleatendimento. Entre essas técnicas encontram-se as baseadas em Automatic Meter Reading (AMR) e sistemas de Power Line Comunication (PLC). Existem ainda sistemas de Predição de Danos e de Despacho de Equipes que também podem ser mais bem estudados. 


\section{REFERÊNCIAS}

AGÊNCIA NACIONAL DE ENERGIA ELÉTRICA (ANEEL). IASC 2005: Índice ANEEL de Satisfação do Consumidor: Relatório Brasil. Brasília, DF, jun. 2006. Disponível em: <http://www.aneel.gov.br/526.htm>. Acesso em: 6 out. 2006.

AGÊNCIA NACIONAL DE TELECOMUNICAÇÕES (ANATEL). Crescimento das Comunicações Móveis (1999-2006). Disponível em: <http://www.anatel.gov.br/indicadores/default.asp>. Acesso em 20 out. 2006.

AGÊNCIA NACIONAL DE TELECOMUNICAÇÕES (ANATEL). Números da TV por Assinatura (1996-2006). Disponível em: 〈http://www.anatel.gov.br/indicadores/default.asp〉. Acesso em 20 out. 2006.

ALENCAR, Marcelo Sampaio. Telefonia Digital. Editora Érica. 1998. 472 p..

ALLBUSINESS.COM. Drive for Blackout Warnings Running Into Legislative Wall. Disponível em: <http://www.allbusiness.com/periodicals/article/781115-1.html>. Acesso em: 11 jul. 2006.

AMORIM, Andréa Rodrigues. O desenvolvimento de aplicações móveis com J2M2. Disponível em: <http://www.teleco.com.br/tutoriais/tutorialj2me/default.asp>. Acesso em: 26 maio 2005.

ARANHA, Maria Lucia de Arruda. Filosofando: Introdução a filosofia.. Editora Moderna. São Paulo, 1986. 443 p.

ASSOCIAÇÃO BRASILEIRA DE E-BUSINESS. Estudo traça panorama e aponta novas tendências no marketing digital. Disponível em: <http://www.ebusinessbrasil.com.br/txt_perfil_pain.php?id=462>. Acesso em 17 nov. 2006.

AVAYA. Avaya Voice Portal: Configuration Note 3910. Avaya Inc. Milpitas, 2006. 12 p.. Disponível em: <http://support.avaya.com/elmodocs2/voice_portal/config/CN3910.pdf>. Acesso em: 16 out. 2006.

AVAYA. Challenger to Contact Center Improvements. Avaya Inc. 2006. Disponível em: <http://www.avaya.com/gcm/master-usa/en-us/wowtopics/contactctservices>. Acesso em: 23 out. 2006.

AVAYA. Predictive Dialing System (GCC0909-04). Avaya Inc. Milpitas, 2003. 12 p.. Disponível em <http://www.avaya.com/master-usa/enus/resource/assets/brochures/gcc0909.pdf>. Acesso em 16 out. 2006. 
BAER, Werner; MCDONALD, Curt. Um retorno ao passado? A privatização de empresas de serviços públicos no brasil: o caso do setor de energia elétrica. Revista de Planejamento e Política Pública do Instituto de Pequisa Econômica Aplicada (IPEA). № 16. 1997. Disponível em: <http://www.ipea.gov.br/pub/ppp/ppp16.html>. Acessado em: 12 Abr 2007.

BALAKRISHNAN, Ravi; PAHWA, Anil. A computer assisted intelligent storm outage evaluator for power distribution systems. IEEE Transaction on Power Delivery, Vol. 5, № 3. jul 1990. 7 p..

BARAKATY, Chadi; THIRAN, Patrick; IANNACCONE, Gianluca; DIOT, Christophe. Modeling Internet backbone traffic at the flow level. IEEE Transactions on Signal Processing - Special Issue On Networking. Vol. 51, № 8. Ago 2003. 12 p..

BEAR, D. Principles of telecommunication: traffic engineering. Editora Stevenage. Peregrinus, 1976.

BLACKIE, N; LINGIE N; BROWN P. Advanced Customer Services, Bringing the Call Center to the Home. IEE Metering and Tariffs for Energy Supply. 28 maio 1999. 5 p..

BRASIL. ANATEL. Regulamentação de Sinalização para Usuários: Anexo a Resolução № 252, de 20 de dezembro de 2000. Brasília, DF, 21 dez 2000.

BRASIL. ANATEL. Resolução № 329, de 29 de janeiro de 2003. Brasília, DF, 29 jan 2003.

BRASIL. ANEEL. Aprova o modelo do Contrato de Prestação de Serviço Publico de Energia Elétrica para Unidades Consumidoras Atendidas em Baixa Tensão. Resolução Normativa № 615, de 6 de Novembro 2002. Brasília, DF, 7 nov. 2002.

BRASIL. ANEEL. Estabelece as disposições relativas à Continuidade da Distribuição de energia elétrica às unidades consumidoras. Resolução Normativa № 24, de 27 de janeiro de 2000. Brasília, DF, 25 jan. 2000.

BRASIL. ANEEL. Estabelece as condições de atendimento por meio de Central de Teleatendimento (CTA) das concessionárias ou permissionárias, critérios de classificação de serviços e metas de atendimento. Resolução Normativa № 57, de 12 de abril de 2004 . Brasília, DF, 13 abr. 2004.

BRASIL. Constituição (1998). Constituição da República Federativa do Brasil, Brasília, DF: Senado, 1988.

BRASIL. Decreto № 2.335, de 6 de Outubro de 1997. Constitui a Agência Nacional de Energia Elétrica - ANEEL. Brasília, DF, 07 out. 1997.

BRASIL. Lei № 10.406, de 10 de Janeiro de 2002. Institui o Código Civil. Brasília, DF, 11 jan. 2002. 
BRASIL. Lei № 8.078, de 11 de Setembro de 1998. Código de Proteção e Defesa do Consumidor. Dispõe sobre a proteção do consumidor e dá outras providências. Brasília, DF, 11 set 1998.

BRASIL. Lei № 8.987, de 13 de Fevereiro de 1995. Dispõe sobre o regime de concessão e permissão da prestação de serviços públicos previsto no art. 175 da Constituição Federal, e dá outras providências. Brasília, DF, 7 nov. 2000.

BRASIL. Lei № 9.074, de 7 de Julho de 1995. Estabelece normas para outorga e prorrogações das concessões e permissões de serviços públicos e dá outras providências. Brasília, DF, 28 set 1998.

BRASIL. Lei № 9.427, de 26 de Dezembro de 1996. Institui a Agência Nacional de Energia Elétrica - ANEEL, disciplina o regime das concessões de serviços públicos de energia elétrica e dá outras providências. Brasília, 27 dez 1996.

CALIFORNIA STATE SENATE. Bill ABX1 52: Legislation. Disponível em: $<$ http://info.sen.ca.gov/pub/01-02/bill/asm/ab_0051-

0100/abx1_52_bill_20010329_amended_asm.html>. Acesso em: 11 jul. 2006.

CEGRELL, T.; EKSTEDT M.; FORSGREN P. Management of enterprise information systems for the power system control and operation. Power System Management and Control - Conference Publication № 488. IEE. 2002. 7 p.

CISCO. Traffic Analysis for Voice over IP. Disponível em < http://www.cisco.com/univercd/cc/td/doc/cisintwk/intsolns/voipsol/ta_isd.htm>. Acesso em: 15 nov. 2006.

CISCO. Voice Over IP: Per Call Bandwidth Consumption. Disponível em <http://kbase/paws/servlet/ViewFile/7934/bwidth_consume.xml>. Acesso em: 15 maio 2006.

CODEBABY. CodeBaby Corporation. Apresenta tecnologia e exemplos de agentes virtuais. Disponível em: <http://www.codebaby.com>. Acesso em: 18 ago. 2006.

CONEDISON. Summer Preparedness 2005: Electrical System Reinforcement. Disponível em: <http://www.coned.com>. Acesso em: 3 out. 2005.

CONNEX. SMS Updates. Disponível em: <http://www.platypusworld.com/connex/webreg/sms_updates.htm>. Acesso em 21 ago. 2006.

COPEL Distribuição. Relatório da Administração e Demonstrações Contábeis 2004. Curitiba, 2004. 86 p.. Disponível em: <http://www.copel.com.br>. Acesso em: 6 nov. 2006.

COSTA NETO, Pedro L. O.; CYMBALISTA, Melvin. Probabilidades. Editora Edgar Bluncher. São Paulo, 1974. 140 p.. 
COX, D. R.; SMITH, Walter L. Queues: Monographs on Applied Probability and Statistics. Editora Chapman and Hall. Londres, 1971. 180 p..

COX, D. R.; SMITH, Walter L. The Statistical Analysis of Series of Events: Monographs on Applied Probability and Statistics. Editora Chapman and Hall. Londres, 1978. 285 p.

DAMAS, J; MIRANCOS. F.; ARIEIRO P. Sistema de Aviso de Interrupções do Fornecimento de Energia Elétrica. SENDI 2004. São Paulo, 2004. 9 p..

DEFESA CIVIL DE SÃO PAULO. Operação Verão. Disponível em: <http://www.defesacivil.sp.gov.br/opverao.asp>. Acessado em: 04 dez. 2006.

ELETROPAULO. Ligado 26: Nov Dez 2005. Disponível em: <http://www.eletropaulo.com.br/portal/page.cfm?conteudo_id=549>. Acesso em: 13 jul 2006.

ERICSSON. Integração CTI. São Paulo, 02 ago. 2000. 17 p..

ERICSSON. Mobile Multimedia: the next step in richer communication. Ericsson Enterprise AB, Estocolmo, mar. 2004. 22 p.. Disponível em: <http://www.ericsson.com/mobilityworld/ >. Acesso em: 31 jul. 2006.

ERICSSON. Solidus eCare Business Integration. Ericsson Enterprise AB, Estocolmo, abr 2004. 4 p.. Disponível em: <http://www.ericsson.com/enterprise/ >. Acesso em: 13 out. 2006.

ERICSSON. Solidus eCare Product Description. Ericsson Enterprise AB, Estocolmo, 2005. 24 p.. Disponível em: <http://www.ericsson.com/enterprise/ >. Acesso em: 13 out. 2006.

ERLANG, Agner Krarup. Solution of some Problems in the Theory of Probabilities of Significance in Automatic Telephone Exchanges. Copenhague, 1917.

ERLANG, Agner Krarup. The Theory of Probabilities and Telephone Conversations. Copenhague, 1909.

FERREIRA, Cláudio. O mercado amadureceu: e agora? Revista TI Inside, São Paulo, № 19, p. 20-21, nov. 2006.

FLORIDA POWER \& LIGHT (FPL). Customer Service. Apresenta modos de reportar defeitos na rede de distribuição. Disponível em: <http://www.fpl.com/residential/customer_service.shtml>. Acesso em: 16 nov. 2005.

FLORIDA POWER \& LIGHT (FPL). Restoration Plan: Storm Center. Disponível em: <http://www.fpl.com/storm/contents/index.shtml>. Acesso em: 16 nov. 2005.

FONSECA, Nelson Luís Saldanha da. Dimensionamento de Links da Internet. Universidade de Campinas. Disponível em: <http://www.gta.ufrj.br/quaresma/publicacao.htm>. Acesso em: 24 abr. 2005. 
GAMA, Maria Gabriela. Quando o Inferno desce a Terra: A gestão de crises e sua problemática. Universidade do Minho. Departamento de Ciências de Comunicação. Portugal, 2000. 8 p.. Disponível em: <https://repositorium.sdum.uminho.pt/handle/1822/5509>. Acesso em: 8 dez. 2006.

GARCIA, Camilo. A batalha do WiMAX. Revista Nacional das Telecomunicações - RNT, São Paulo, № 311, p. 16-20, nov. 2005.

GOVERNO DO ESTADO DE SÃO PAULO. Secretaria da Energia e Recursos Hídricos. Série Informações Energéticas: Boletim Informativo Setembro 2006. Disponível em <http:www.cspe.gov.sp.br>. Acesso em: 7 nov. 2006.

GOVERNPUB. Communication. Disponível em <http://www.governpub.com/gt/communicaion.html>. Acessado em: 13 nov. 2006.

HEWLETT-PACKARD. HP iPAQ hw6900 Mobile Messenger. Disponível em $<$ http://h20285.www2.hp.com/estore/families.asp?chassis=handheld\&value=22\&p_family_id $=78 \&$ family_id=622> . Acesso em: 17 nov. 2006 .

INSTITUTE OF ELECTRICAL AND ELECTRONICS ENGINEERS (IEEE). Information Security: Na Integrated Collection of Essays. IEEE Computer Society Press. Disponível em <http://www.acsac.org/secshelf/book001/book001.html>. Acesso em: 02 fev. 2005.

INSTITUTO BRASILEIRO DE GEOGRAFIA E ESTATISTICA (IBGE). Pesquisa Nacional por Amostra de Domicílios 2005. Disponível em: <http://www.ibge.gov.br/home/estatistica/populacao/trabalhoerendimento/pnad2005/default.s htm>. Acesso em: 23 out. 2006.

INTEL Telephony Fundamentals: An Introduction to Basic Telephony Concepts. Intel in Communications. Parsippany, 2003. $11 \quad$ p.. $\quad$ Disponível em <http://www.intel.com/network/csp/pdf/3146wp.htm>. Acesso em: 14 dez. 2006.

INTEL The Next Big Opportunity on the Web. Intel e-Business Center. Parsippany, 2001. 8 p.. Disponível em: <http://www.intel.com/network/csp/resources/white_papers/6942web.htm>. Acesso em: 14 dez. 2006.

INTEL. Communication Web Services: Bringing the Value of the Web to Voice Solutions. Inter Corporation. Parsippany, 2004. 9 p.. Disponível em: <http://www.intel.com/network/csp/pdf/8857wp.htm>. Acesso em 14 dez. 2006.

INTEL. Megatrends in the Contact Center. Intel in Communications. Parsippany, 2004. 10 p.. Disponível em: <http://www.intel.com/network/csp/pdf/9167wp.htm>. Acesso em: 14 dez. 2006.

INTERNATIONAL TELECOMMUNICATION UNION (ITU-D). Teletraffic Engineering Handbook. Geneva, 2005. 350 p.. 
INTERNATIONAL TELECOMMUNICATION UNION. Telecommunication Standardization Sector (ITU-T). Recommendation E.492: Telephone Network and ISDN Quality of Service, Network Management and Traffic Engineering. 1996. 6 p..

INTERNATIONAL TELECOMMUNICATION UNION. Telecommunication Standardization Sector (ITU-T). Recommendation E.500: Traffic intensity measurements principles. 1998.

INTERNATIONAL TELECOMMUNICATION UNION. Telecommunication Standardization Sector (ITU-T). Recommendation E.733: Overall Network Operation, Telephone Service, Service Operation and Human Factor. 1998. 13 p..

JEFKINS, Frank. Public Relations Techniques. Butterworth-Heinemann, Oxford, 1994. 372 p..

JESZENSKY, Paul Jean. Sistemas Telefônicos. Editora Marole. Barueri, 2004. 651 p..

KEARNEY, Steve. How Outage Management Systems Can Improve Customer Service. IEEE. 1998. 7 p..

KENDALL, David G. Stochastic Processes Occurring in the Theory of Queues and their Analysis by the Method of the Imbedded Markov Chain. EUA, 1953.

KIRSCHEN, Daniel S.; VOLKMANN, Terry L.. Guiding a power system restoration with an expert system. IEEE Transactions on Power Systems, Vo1. 6, № 2. Maio 1991.

KLINKMANN. GSM Control SMS software for PC. Helsinki, 2005. 4 p.. Disponível em <http://www.klinkmann.com>. Acesso em: 22 ago. 2006.

KOOLE, Ge. Call Center Mathematics. 2006. Vrije Universiteit Amsterdam. Disponível em: <http://www.math.vu.nl/ koole/ccmath>. Acesso em: 10 jul. 2006.

KOOLE, Ge. GANS, Noah. MANDELBAUM, Avishai. Telephone Call Centers: Tutorial, Review, and Research Prospects. 2003. Vrije Universiteit Amsterdam. Disponível em: <http://www.math.vu.nl/koole>. Acesso em: 10 jul. 2006.

LASTRES, Helena M. M. Informação e conhecimento na nova ordem mundial. Instituto Brasileiro de Informação e Ciência e Tecnologia. Brasília, 1999. Disponível em: <http://dici.ibict.br/archive/00000190/01/Ci[1].Inf-2004-366.pdf>. Acesso em: 14 dez. 2006.

LAU, Marcelo. Análise das fraudes aplicadas sobre o ambiente de Internet Banking. Dissertação de Mestrado. Programa de Pós-graduação da Escola Politécnica da Universidade de São Paulo, São Paulo, 2006. 119 p.. 
LAVESQUE, Carl J.. Outage Management: Liability or Marketing ? Public Utilities Reports. Viena, 15 fev. 2000. Disponível em: <http://www.pur.com/pubs/3405.cfm>. Acesso em 23 out. 2006.

LEITE, Leonardo Henrique de Melo. Modelo de Interceptação Autorizada de Chamadas para o Sistema Telefônico Brasileiro. Dissertação de Mestrado. Programa de PósGraduação em Engenharia Elétrica da Universidade Federal de Minas Gerais, Belo Horizonte, 2005. 151 p..

LUBKEMAN, David; JULIAN, Danny E.. Large Scale Storm Outage Management. IEEE. Ano provável: 2001.7 p..

MACFARLANE, Derek. Outage Management in Scottish Power. IEEE. 1998. 6 p..

MIRANDA, Antonio. Sociedade da informação: globalização, identidade cultural e conteúdos. Instituto Brasileiro de Informação em Ciência e Tecnologia. Brasília, 2000. Disponível em: $<$ http://www.ibict.br/cienciadainformacao/include/getdoc.php?id=594\&article=295\&mode=p df: Acesso em 14 dez. 2006.

MOREIRA, Gabrielle. A tal da terceirização. Revista B2B Magazine, São Paulo, № 68, p. 58-62, set 2006.

MURPHY, C., BALLENTINE, R.; ROONEY, Hugh. In search of world class performance during fault situations. IEE CIRED 2001. 21 jun. 2001. 5 p..

NATIONAL ASSOCIATION OF STATE OF ENERGY (NASEO). Office of Eletricity Delivery and Energy Reliability. Florida State's Energy Emergency Response to the 2004 Hurricanes. Disponível em: $<$ http://www.naseo.org/Committees/energysecurity/documents/florida_response.pdf $>$. Acesso em 28 nov. 2005.

NET.COM. Solução Shout IP para serviços VoIP de Nova Geração. São Paulo, 1 jul. 2005. 21 p.. Disponível em: <http:www.net.com>. Acesso em: 14 dez. 2006.

NOGUEIRA, Nadia Gasparotto. SMS na Telefonia Fixa. 2005. Disponível em: <http://www.teleco.com.br/tutoriais/tutorialsms/default.asp>. Acesso em: 26 abr. 2006.

NOKIA.

Tecnologias.

Disponível

em:

<http://www.nokia.com.br/nokia/0,8764,43724,00.html>. Acesso em: 16 out. 2006.

NORTHERN IRELAND ELECTRICITY (NIE). Contact Us. Disponível em: <http://www.nie.co.uk/contactus/index.htm>. Acesso em: 16 out. 2006.

OFFICE FOR THE REGULATION OF ELECTRICITY \& GAS (OFREG). Northern Ireland Snowstorms Report. Disponível em: <http://ofreg.nics.gov.uk/9\%20May\%202001.htm>. Acesso em: 16 nov. 2005. 
OFFICE OF ELECTRICITY DELIVERY AND ENERGY RELIABILITY. U.S. DEPARTMENT OF ENERGY. Hurricane Katrina Situation Report \#1. Washington, August 26, $2005 \quad(10: 30 \quad$ AM $\quad$ EDT $) .22$ p.. Disponível em: <http://www.oe.netl.doe.gov/docs/katrina>. Acesso em: 28 nov. 2005.

OFFICE OF ELECTRICITY DELIVERY AND ENERGY RELIABILITY. U.S. DEPARTMENT OF ENERGY. Hurricane Katrina Situation Report \#8. Washington, August 29, $2005 \quad(16: 00$ AM EDT). Disponível em: <http://www.oe.netl.doe.gov/docs/katrina>. Acesso em: 28 nov. 2005.

PEPERS AND ROGERS GROUP. CRM Series: Marketing One to One. Makron Books. $2^{\circ}$ edição. São Paulo, 2001. 102 p..

PEPPERS, Don; ROGERS, Martha. The One to One Future: Building Relationships One Customer at a Time. Doubleday Publishing. New York, 1993.

PROMOM. Mobilidade: A grande tendência do futuro. Business \& Technology Review. São Paulo, 2005.

PROMOM. Segurança da Informação. Business \& Technology Review. São Paulo, 2005.

RABAÇA, Carlos Alberto. BARBOSA, Gustavo. Dicionário da Comunicação. Editora Campus. 2001. Brasil.

RIZZO, Esmeralda. Uma Análise Comparativa entre o Marketing de Massa e "One to One" Marketing, no Cenário de Empresas Competitivas. Universidade da Beira Interior. Portugal, Covilhã, 2003. Disponível em: <http://www.bocc.ubi.pt/pag/rizzo-esmeraldaanalise-comparativa.pdf>. Acesso em: 14 dez. 2006.

ROCHA, Antonio A. de A.; SILVA, Edmundo de Souza; LEÃO, Rosa M. M.. Uma ferramenta para estimar características fim-a-fim na Internet. Universidade Federal do Rio de Janeiro. Rio de Janeiro, 2003. 4 p.. Disponível em: <http://www.rnp.br/_arquivo/wrnp2/2003/ufecf01.pdf>. Acesso em: 19 set. 2005.

ROESLER, Valter; FINZSCH, Peter; ANDRADE, Maiko; LIMA, José Valdeni de. Análise do mecanismo de pares de pacotes visando estimar a banda da rede via UDP. Universidade Federal do Rio Grande do Sul. Porto Alegre, 2004. 16 p.. Disponível em: <http://www.inf.unisinos.br/ roesler/publicados/2003_sbrc/pp_sbrc2003.pdf >. Acesso em: 19 set. 2005.

SCOTTISH POWER. Contact Us. Disponível em: <http:/ /www.scottishpower.co.uk/contactus/contactus.asp>. Acesso em: 16 out. 2006.

SHANnON, C. E.. A Mathematical Theory of Communication. The Bell System Technical Journal. Vol. 27, pp. 379-423, 623-656. EUA, Out 1948. 55 p.. 
SIEMENS. Hipath ProCenter. São Paulo, jun. 2001. 24 p.. Disponível em: <http://www.siemens.com.br/catalogosemanuais>. Acesso em 16 out. 2006.

SRIDHARAN, Krishna; SCHULZ, Noel N.. Outage Management Through AMR Systems Using an Intelligent Data Filter. IEEE Transactions on Power Delivery, Vol. 16, № 4, out. 2001. 7 p..

STANTON, M.A; BARRA, L.F.S; BASTOS, C.A.M. Integração de Serviços na Internet. Universidade Federal Fluminense. Niterói, 1996. 45 p.. Disponível em: <http://www.ic.uff.br/ michael/SocVirt.htm>. Acesso em: 14 dez. 2006.

STOCKER, Kurt P. Strategic Approach to Crisis Management: The handbook of strategic public relations \& integrated communications. Caywood, Clarke L. Editora McGraw-Hill. New York, 1997. 608 p..

SUN Microsystems. Java Technology. Disponível em: <http://www.sun.com/java>. Acesso em: 16 out. 2006.

TELETIME. Atlas Brasileiro de Telecomunicações. Editora Glasberg. São Paulo, 2006. 170 p..

TERZIAN, Françoise. Todo poder ao Cobit. Revista Info Corporate, São Paulo, № 38, p. 60-71, nov. 2006.

UNITED STATES OF AMERICA DEPARTMENT OF ENERGY. National Electric Delivery Technologies Roadmap - Transforming the grid to revolutionize electric power in North America. Washington, nov. 2003. 72 p.. Disponível em: $<$ http://www.oe.energy.gov/DocumentsandMedia/Electric_Vision_Document.pdf $>$. Acesso em: 19 set. 2005

UNITED STATES OF AMERICA DEPARTMENT OF ENERGY. Power Outage Task Force Posts Public Recommendations on August 2003 Blackout, Seeks Further Comment. Press Room: 4 de Fevereiro de 2004. Disponível em: <http:// www.energy.gov/news/1263.htm>. Acesso em: 19 set. 2005

VOICE XML FORUM. Fórum global que discute e sugere padrões para o XML. Disponível em: <http://www.voicexml.org>. Acesso em: 30 jan. 2006.

WALTER, Rob. Computer Telephony Integration. Editora Artech House. $2^{\text {a }}$ Edição. Norwood, 1998. 462 p..

ZIVIANI, Artur. DUARTE, Otto Carlos M. B. Metrologia na Internet. XXIII Simpósio Brasileiro de Redes de Computadores SBRC'2005. Fortaleza, maio 2005. 44 p.. Disponível em: <http://www.gta.ufrj.br/ftp/gta/TechReports/ZiDu05.pdf>. Acesso em: 14 dez. 2006. 


\section{APÊNDICE A}

Tabela 14: Quantidade total diária de Circuitos Interrompidos em situação de emergência [ CIH ], apurado no período de 12 meses

\begin{tabular}{|c|c|c|c|c|c|c|c|c|c|c|c|c|}
\hline & \multicolumn{1}{|c|}{ ANO DE 2004 } & \multicolumn{10}{|c|}{ ANO DE 2005 } \\
\hline DIA & OUT & NOV & DEZ & JAN & FEV & MAR & ABR & MAI & JUN & JUL & AGO & SET \\
\hline 1 & 12 & 9 & 17 & 9 & 13 & 15 & 10 & 3 & 14 & 9 & 15 & 9 \\
\hline 2 & 9 & 3 & 12 & 8 & 9 & 11 & 4 & 16 & 12 & 5 & 16 & 12 \\
\hline 3 & 2 & 16 & 11 & 19 & 13 & 11 & 3 & 14 & 10 & 3 & 11 & 3 \\
\hline 4 & 12 & 12 & 4 & 23 & 12 & 15 & 12 & 12 & 4 & 16 & 11 & 4 \\
\hline 5 & 12 & 11 & 3 & 22 & 6 & 4 & 13 & 12 & 2 & 12 & 10 & 34 \\
\hline 6 & 10 & 3 & 17 & 19 & 3 & 4 & 14 & 14 & 13 & 16 & 5 & 12 \\
\hline 7 & 11 & 3 & 10 & 22 & 6 & 12 & 12 & 5 & 11 & 12 & 2 & 5 \\
\hline 8 & 11 & 12 & 8 & 8 & 3 & 13 & 14 & 2 & 13 & 16 & 17 & 11 \\
\hline 9 & 4 & 10 & 13 & 3 & 9 & 14 & 4 & 13 & 10 & 3 & 13 & 10 \\
\hline 10 & 6 & 14 & 8 & 13 & 13 & 11 & 2 & 14 & 12 & 2 & 13 & 4 \\
\hline 11 & 11 & 13 & 3 & 11 & 12 & 15 & 13 & 12 & 3 & 12 & 12 & 3 \\
\hline 12 & 2 & 14 & 2 & 8 & 3 & 5 & 11 & 13 & 2 & 14 & 10 & 15 \\
\hline 13 & 15 & 4 & 12 & 12 & 2 & 2 & 11 & 21 & 11 & 16 & 3 & 11 \\
\hline 14 & 14 & 1 & 7 & 11 & 10 & 17 & 11 & 4 & 13 & 15 & 2 & 12 \\
\hline 15 & 16 & 2 & 16 & 5 & 11 & 14 & 12 & 2 & 10 & 12 & 14 & 11 \\
\hline 16 & 8 & 20 & 15 & 4 & 11 & 11 & 4 & 16 & 9 & 5 & 14 & 12 \\
\hline 17 & 15 & 13 & 20 & 14 & 12 & 10 & 3 & 14 & 12 & 4 & 11 & 5 \\
\hline 18 & 21 & 15 & 10 & 17 & 11 & 11 & 16 & 12 & 5 & 20 & 11 & 2 \\
\hline 19 & 20 & 14 & 2 & 10 & 8 & 6 & 11 & 9 & 3 & 16 & 11 & 12 \\
\hline 20 & 20 & 4 & 12 & 10 & 3 & 3 & 12 & 11 & 12 & 14 & 5 & 12 \\
\hline 21 & 18 & 1 & 10 & 10 & 11 & 15 & 3 & 3 & 11 & 16 & 2 & 10 \\
\hline 22 & 16 & 13 & 12 & 4 & 12 & 11 & 8 & 4 & 16 & 16 & 21 & 8 \\
\hline 23 & 3 & 14 & 9 & 3 & 15 & 11 & 3 & 10 & 17 & 5 & 15 & 10 \\
\hline 24 & 2 & 12 & 4 & 13 & 13 & 12 & 2 & 16 & 10 & 3 & 13 & 4 \\
\hline 25 & 17 & 10 & 3 & 11 & 15 & 2 & 12 & 25 & 5 & 18 & 8 & 4 \\
\hline 26 & 16 & 8 & 5 & 9 & 7 & 3 & 13 & 4 & 2 & 15 & 8 & 10 \\
\hline 27 & 10 & 6 & 13 & 10 & 3 & 1 & 11 & 8 & 13 & 10 & 7 & 8 \\
\hline 28 & 11 & 5 & 9 & 9 & 14 & 10 & 13 & 4 & 10 & 13 & 3 & 8 \\
\hline 29 & 10 & 19 & 8 & 5 & 0 & 11 & 27 & 2 & 12 & 12 & 12 & 11 \\
\hline 30 & 4 & 13 & 11 & 3 & 0 & 11 & 5 & 11 & 10 & 5 & 10 & 9 \\
\hline 31 & 2 & 0 & 5 & 11 & 0 & 10 & 0 & 13 & 0 & 3 & 10 & 0 \\
\hline & & & & & & & & & & & \\
\hline
\end{tabular}




\section{APÊNDICE B}

Tabela 15: Chamadas Atendidas [ CA ], apurado no período de 12 meses

\begin{tabular}{|c|c|c|c|c|c|c|c|c|c|c|c|c|}
\hline & \multicolumn{3}{|c|}{ ANO DE 2004} & \multicolumn{9}{|c|}{ ANO DE 2005} \\
\hline DIA & OUT & NOV & DEZ & JAN & FEV & MAR & ABR & MAI & JUN & JUL & AGO & SET \\
\hline 1 & 25444 & 17987 & 34235 & 18785 & 27384 & 27731 & 26075 & 6400 & 26011 & 23880 & 29593 & 24418 \\
\hline 2 & 17518 & 8862 & 26329 & 20632 & 24608 & 27990 & 8588 & 30703 & 25091 & 11398 & 29417 & 23479 \\
\hline 3 & 5733 & 39372 & 25903 & 41313 & 27425 & 28113 & 6186 & 28864 & 24340 & 8322 & 27700 & 9040 \\
\hline 4 & 30480 & 31461 & 11136 & 46540 & 30686 & 28123 & 29873 & 28833 & 10046 & 30768 & 23405 & 12317 \\
\hline 5 & 31391 & 25068 & 6992 & 43435 & 14428 & 10264 & 29717 & 28259 & 6314 & 25484 & 24031 & 65192 \\
\hline 6 & 27031 & 7753 & 33214 & 40064 & 6519 & 10811 & 30080 & 28612 & 28468 & 31468 & 10095 & 28773 \\
\hline 7 & 21573 & 8357 & 27043 & 46615 & 14277 & 32157 & 27417 & 10101 & 26480 & 32841 & 7455 & 10700 \\
\hline 8 & 25030 & 26569 & 20808 & 18280 & 6439 & 30626 & 29507 & 6658 & 27456 & 35795 & 32072 & 25671 \\
\hline 9 & 10978 & 25656 & 28982 & 8819 & 24361 & 32034 & 9428 & 30383 & 25517 & 8657 & 26913 & 24752 \\
\hline 10 & 11923 & 26608 & 20335 & 32891 & 27331 & 29034 & 5131 & 28667 & 24908 & 6041 & 26460 & 11065 \\
\hline 11 & 23134 & 25847 & 8910 & 23601 & 27732 & 34390 & 30764 & 28566 & 9315 & 32805 & 26186 & 7461 \\
\hline 12 & 5122 & 27532 & 4094 & 22190 & 7996 & 11682 & 30148 & 26931 & 5475 & 32006 & 23489 & 30770 \\
\hline 13 & 28140 & 8404 & 24997 & 23157 & 5830 & 7349 & 26545 & 41498 & 26423 & 30927 & 10114 & 26907 \\
\hline 14 & 27199 & 3084 & 19612 & 28052 & 26799 & 38952 & 25308 & 10438 & 25965 & 31260 & 5607 & 29419 \\
\hline 15 & 31676 & 5428 & 30869 & 11081 & 27682 & 36239 & 27376 & 6420 & 26471 & 31279 & 28523 & 28866 \\
\hline 16 & 15183 & 43033 & 28223 & 9269 & 28146 & 27686 & 10764 & 32037 & 24821 & 14148 & 28518 & 24311 \\
\hline 17 & 32060 & 35815 & 49459 & 29415 & 28963 & 27617 & 7598 & 30346 & 24389 & 11305 & 28171 & 12396 \\
\hline 18 & 43900 & 28158 & 25483 & 34975 & 27309 & 25839 & 30917 & 27601 & 10737 & 37825 & 27741 & 5909 \\
\hline 19 & 45204 & 27891 & 6650 & 26371 & 18007 & 12391 & 25585 & 24378 & 6732 & 31311 & 21324 & 29341 \\
\hline 20 & 43786 & 7655 & 31714 & 24671 & 5990 & 5818 & 27306 & 27087 & 32430 & 31617 & 12467 & 25140 \\
\hline 21 & 39183 & 3394 & 26359 & 25162 & 28197 & 27129 & 9607 & 9507 & 27507 & 32871 & 7341 & 23603 \\
\hline 22 & 35250 & 25421 & 28322 & 10280 & 27045 & 26251 & 16343 & 9394 & 37237 & 33262 & 43080 & 20648 \\
\hline 23 & 9747 & 28685 & 20224 & 8876 & 29584 & 26781 & 9273 & 27871 & 31191 & 12508 & 34615 & 19518 \\
\hline 24 & 4761 & 29693 & 10375 & 31401 & 32124 & 27256 & 4863 & 33316 & 24145 & 7006 & 27365 & 9936 \\
\hline 25 & 38142 & 25060 & 8246 & 28492 & 37497 & 6054 & 27794 & 49464 & 11863 & 39584 & 20857 & 10270 \\
\hline 26 & 33348 & 20095 & 10728 & 25724 & 16533 & 7930 & 32644 & 10624 & 7088 & 32933 & 20399 & 26888 \\
\hline 27 & 26132 & 15261 & 24853 & 22562 & 9178 & 4629 & 29564 & 20681 & 26414 & 26556 & 15922 & 20936 \\
\hline 28 & 28415 & 11053 & 22208 & 22808 & 29909 & 24022 & 24439 & 8044 & 26144 & 24936 & 7231 & 21089 \\
\hline 29 & 27740 & 36470 & 19223 & 12039 & & 22245 & 52241 & 7220 & 26152 & 24999 & 27204 & 21591 \\
\hline 30 & 9735 & 33380 & 27296 & 7656 & & 21783 & 12652 & 24437 & 19873 & 10899 & 26527 & 23485 \\
\hline 31 & 6632 & & 12678 & 25186 & & 23464 & & 25244 & & 6788 & 23856 & \\
\hline
\end{tabular}




\section{APÊNDICE C}

Tabela 16: Índice de Chamadas Ocupadas [ ICO ], apurado no período de 12 meses

\begin{tabular}{|c|c|c|c|c|c|c|c|c|c|c|c|c|}
\hline \multirow[b]{2}{*}{ DIA } & \multicolumn{3}{|c|}{ ANO DE 2004} & \multicolumn{9}{|c|}{ ANO DE 2005} \\
\hline & OUT & NOV & DEZ & JAN & FEV & MAR & ABR & MAI & JUN & JUL & AGO & SET \\
\hline 1 & $0,13 \%$ & $0,01 \%$ & & $0,05 \%$ & & & & & & & & \\
\hline 2 & & & & & & & & & & & & \\
\hline 3 & $3 \%$ & & & $0,05 \%$ & $0,01 \%$ & & $05 \%$ & & $05 \%$ & $0,01 \%$ & $01 \%$ & $10 \%$ \\
\hline 4 & $3 \%$ & $0,01 \%$ & & $5,00 \%$ & & & & & $0,05 \%$ & & & $0,10 \%$ \\
\hline 5 & $13 \%$ & $0,01 \%$ & & $5,00 \%$ & $0,01 \%$ & $0,01 \%$ & $0,05 \%$ & & $0,05 \%$ & $0,01 \%$ & $0,01 \%$ & $15,00 \%$ \\
\hline 6 & $13 \%$ & $0,01 \%$ & $0,08 \%$ & $0,05 \%$ & $0,01 \%$ & $0,01 \%$ & $0,05 \%$ & & $0,05 \%$ & $0,01 \%$ & $0,01 \%$ & $0,10 \%$ \\
\hline 7 & & & & & & & & & & & & \\
\hline 8 & & & & & & & & & & & & \\
\hline 9 & & & & & & & & & & & & \\
\hline 10 & & & & & & & & & & & & \\
\hline 11 & & & & $0,05 \%$ & & & & & $0,05 \%$ & & $01 \%$ & \\
\hline 12 & & & & $0,05 \%$ & $0,01 \%$ & & & $0,10 \%$ & $0,05 \%$ & & $0,01 \%$ & \\
\hline 13 & $0,13 \%$ & $0,01 \%$ & $0,08 \%$ & $0,05 \%$ & $0,01 \%$ & $0,01 \%$ & 0,0 & 5,0 & $0,05 \%$ & & $0,01 \%$ & $0,10 \%$ \\
\hline 14 & $0,13 \%$ & $0,01 \%$ & $0,08 \%$ & $0,05 \%$ & $0,01 \%$ & 0,01 & 0,05 & & $05 \%$ & & & \\
\hline 15 & & & & & & & & & & & & \\
\hline 16 & & & & & & & & & $05 \%$ & & & \\
\hline 17 & & & & & & & & & $0,05 \%$ & & & \\
\hline 18 & & & & $0,05 \%$ & 0,0 & & $\%$ & & $5,00 \%$ & & $0,01 \%$ & \\
\hline 19 & & $0,01 \%$ & & $0,05 \%$ & $0,01 \%$ & $0,01 \%$ & & & $0,05 \%$ & & $0,01 \%$ & $0,10 \%$ \\
\hline 20 & $5,00 \%$ & $0,01 \%$ & $0,08 \%$ & $0,05 \%$ & $0,01 \%$ & $0,01 \%$ & & & $0,05 \%$ & & $0,01 \%$ & $0,10 \%$ \\
\hline 21 & $0,13 \%$ & $0,01 \%$ & $0,08 \%$ & $0,05 \%$ & $0,01 \%$ & $0,01 \%$ & $0,05 \%$ & $0,10 \%$ & $0,05 \%$ & 0,01 & $0,01 \%$ & $0,10 \%$ \\
\hline 22 & & & & & & & & & & & & \\
\hline 23 & & & & & & & & & & & & \\
\hline 24 & & & & & & & & & $0,05 \%$ & & & \\
\hline 25 & $3 \%$ & $0,01 \%$ & 0,0 & $0,05 \%$ & $0,01 \%$ & $0,01 \%$ & $0,05 \%$ & $00 \%$ & $0,05 \%$ & $0,01 \%$ & $0,01 \%$ & $0,10 \%$ \\
\hline 26 & $0,13 \%$ & $0,01 \%$ & & $0,05 \%$ & $0,01 \%$ & $0,01 \%$ & $0,05 \%$ & $0,10 \%$ & $0,05 \%$ & $0,01 \%$ & $0,01 \%$ & $0,10 \%$ \\
\hline 27 & $0,13 \%$ & $0,01 \%$ & $0,08 \%$ & $0,05 \%$ & $0,01 \%$ & $0,01 \%$ & $0,05 \%$ & $0,10 \%$ & $0,05 \%$ & $0,01 \%$ & $0,01 \%$ & $0,10 \%$ \\
\hline 28 & $0,13 \%$ & $0,01 \%$ & $0,08 \%$ & $0,05 \%$ & $0,01 \%$ & $0,01 \%$ & $0,05 \%$ & $0,10 \%$ & $0,05 \%$ & $0,01 \%$ & $0,01 \%$ & $0,10 \%$ \\
\hline 29 & $0,13 \%$ & $0,01 \%$ & $0,08 \%$ & $0,05 \%$ & & $0,01 \%$ & $1,00 \%$ & $0,10 \%$ & $0,05 \%$ & $0,01 \%$ & $0,01 \%$ & $0,10 \%$ \\
\hline 30 & $0,13 \%$ & $0,01 \%$ & $0,08 \%$ & $0,05 \%$ & & $0,01 \%$ & $0,05 \%$ & $0,10 \%$ & $0,05 \%$ & $0,01 \%$ & $0,01 \%$ & $0,10 \%$ \\
\hline 31 & $0,13 \%$ & & $0,08 \%$ & $0,05 \%$ & & $0,01 \%$ & & $0,10 \%$ & & $0,01 \%$ & $0,01 \%$ & \\
\hline Soma & $18,50 \%$ & $5,25 \%$ & $7,38 \%$ & $16,53 \%$ & $0,19 \%$ & $0,36 \%$ & $2,53 \%$ & $12,85 \%$ & $6,48 \%$ & $0,31 \%$ & $0,22 \%$ & $17,97 \%$ \\
\hline
\end{tabular}




\section{APÊNDICE D}

Tabela 17: Consumidores Desligados $\left[\left(D_{\text {ess }}\right)_{\mathrm{w}_{0}}\right.$ até $\left.\left(D_{\text {esi }}\right)_{\mathrm{w}_{d}}\right]$

\begin{tabular}{|c|c|c|c|c|c|c|c|c|c|c|c|c|}
\hline \multirow[b]{2}{*}{$\begin{array}{c}\mathrm{W} \\
\text { (dia) }\end{array}$} & \multicolumn{3}{|c|}{ ANO DE 2004} & \multicolumn{9}{|c|}{ ANO DE 2005} \\
\hline & OUT & NOV & DEZ & JAN & FEV & MAR & ABR & MAI & JUN & JUL & AGO & SET \\
\hline 1 & 60000 & 45000 & 85000 & 45000 & 65000 & 75000 & 50000 & 15000 & 70000 & 45000 & 75000 & 45000 \\
\hline 2 & 45000 & 15000 & 60000 & 40000 & 45000 & 55000 & 20000 & & 60000 & 25000 & 80000 & \\
\hline 3 & 10000 & 80000 & 55000 & 95000 & 65000 & 55000 & 15000 & 70000 & 50000 & 15000 & 55000 & 15000 \\
\hline 4 & 60000 & 60000 & 20000 & 115000 & 60000 & 75000 & 60000 & 60000 & 20000 & 80000 & 55000 & 20000 \\
\hline 5 & 60000 & 55000 & 15000 & 110000 & 30000 & 20000 & 65000 & 60000 & 10000 & 60000 & 50000 & 170000 \\
\hline 6 & 50000 & 15000 & 85000 & 95000 & 15000 & 20000 & 70000 & 70000 & 65000 & 80000 & 25000 & 60000 \\
\hline 7 & 55000 & 15000 & 50000 & 110000 & 30000 & 60000 & 60000 & 25000 & 55000 & 60000 & 10000 & 25000 \\
\hline 8 & 55000 & 60000 & 40000 & 40000 & 15000 & 65000 & 70000 & 10000 & 65000 & & 85000 & 55000 \\
\hline 9 & 20000 & 50000 & 65000 & 15000 & 45000 & 70000 & 20000 & 65000 & 50000 & 15000 & 65000 & 50000 \\
\hline 10 & 30000 & 70000 & 40000 & 65000 & 65000 & 55000 & 10000 & 70000 & 60000 & 10000 & 65000 & 20000 \\
\hline 11 & 55000 & 65000 & 15000 & 55000 & 60000 & 75000 & 65000 & 60000 & 15000 & 60000 & 60000 & 15000 \\
\hline 12 & 10000 & 70000 & 10000 & 40000 & 15000 & 25000 & 55000 & 65000 & 10000 & 70000 & 50000 & 75000 \\
\hline 13 & 75000 & 20000 & 60000 & 60000 & 10000 & 10000 & 55000 & 105000 & 55000 & 80000 & 15000 & 55000 \\
\hline 14 & 70000 & 5000 & 35000 & 55000 & 50000 & 85000 & 55000 & 20000 & 65000 & 75000 & 10000 & 60000 \\
\hline 15 & 80000 & 10000 & 80000 & 25000 & 55000 & 70000 & 60000 & 10000 & 50000 & 60000 & 70000 & 55000 \\
\hline 16 & 40000 & 100000 & 75000 & 20000 & 55000 & 55000 & 20000 & 80000 & 45000 & 25000 & 70000 & 60000 \\
\hline 17 & 75000 & 65000 & 100000 & 70000 & 60000 & 50000 & 15000 & 70000 & 60000 & 20000 & 55000 & 25000 \\
\hline 18 & 105000 & 75000 & 50000 & 85000 & 55000 & 55000 & 80000 & 60000 & 25000 & 100000 & 55000 & 10000 \\
\hline 19 & 100000 & 70000 & 10000 & 50000 & 40000 & 30000 & 55000 & 45000 & 15000 & 80000 & 55000 & 60000 \\
\hline 20 & 100000 & 20000 & 60000 & 50000 & 15000 & 15000 & 60000 & 55000 & 60000 & 70000 & 25000 & 60000 \\
\hline 21 & 90000 & 5000 & 50000 & 50000 & 55000 & 75000 & 15000 & 15000 & 55000 & 80000 & 10000 & 50000 \\
\hline 22 & 80000 & 65000 & 60000 & 20000 & 60000 & & 40000 & 20000 & 80000 & & 105000 & 40000 \\
\hline 23 & 15000 & 70000 & 45000 & 15000 & 75000 & 55000 & 15000 & 50000 & 85000 & 25000 & 75000 & 50000 \\
\hline 24 & 10000 & 60000 & 20000 & 65000 & 65000 & 60000 & 10000 & 80000 & 50000 & 15000 & 65000 & 20000 \\
\hline 25 & 85000 & 50000 & 15000 & 55000 & 75000 & 10000 & 60000 & 125000 & 25000 & 90000 & 40000 & 20000 \\
\hline 26 & 80000 & 40000 & 25000 & 45000 & 35000 & 15000 & 65000 & 20000 & 10000 & 75000 & 40000 & 50000 \\
\hline 27 & 50000 & 30000 & 65000 & 50000 & 15000 & 5000 & 55000 & 40000 & 65000 & 50000 & 35000 & 40000 \\
\hline 28 & 55000 & 25000 & 45000 & 45000 & 70000 & 50000 & 65000 & 20000 & 50000 & 65000 & 15000 & 40000 \\
\hline 29 & 50000 & 95000 & 40000 & 25000 & 0 & 55000 & 135000 & 10000 & 60000 & 60000 & 60000 & 55000 \\
\hline 30 & 20000 & 65000 & 55000 & 15000 & 0 & 55000 & 25000 & 55000 & 50000 & 25000 & 50000 & 45000 \\
\hline 31 & 10000 & 0 & 25000 & 55000 & 0 & 50000 & 0 & 65000 & 0 & 15000 & 50000 & 0 \\
\hline
\end{tabular}




\section{APÊNDICE E}

Tabela 18: Chamadas Oferecidas [ $(\mathrm{COf})_{\mathrm{w}_{0}}$ até $(\mathrm{COf})_{\mathrm{w}_{\mathrm{d}}}$ ]

\begin{tabular}{|c|c|c|c|c|c|c|c|c|c|c|c|c|}
\hline & \multicolumn{3}{|c|}{ ANO DE 2004} & \multicolumn{9}{|c|}{ ANO DE 2005} \\
\hline W (DIA) & OUT & NOV & DEZ & JAN & FEV & MAR & ABR & MAI & JUN & JUL & AGO & SET \\
\hline 1 & 25476 & 17989 & 34262 & 18795 & 27386 & 27734 & 26089 & 6406 & 26024 & 23882 & 29595 & 24443 \\
\hline 2 & & & & & & & & & & & & \\
\hline 3 & 440 & 39375 & 5924 & 41336 & 27427 & 28116 & 189 & & & 8323 & & \\
\hline 4 & 518 & 1464 & 11145 & 8989 & 30688 & 28126 & 29889 & 28861 & 10051 & 30771 & 23407 & 12330 \\
\hline 5 & 430 & 25070 & 6998 & 45721 & 14429 & 10265 & 29733 & 28287 & 6317 & 25487 & 24033 & 76696 \\
\hline 6 & 7065 & 7754 & 33240 & 40086 & 6519 & 10812 & 30096 & 28640 & 28483 & 31471 & 10096 & 28802 \\
\hline 7 & 600 & 8358 & 27064 & 49068 & 14278 & 32161 & 27431 & 10111 & 6494 & 32844 & 7456 & 10711 \\
\hline 8 & 061 & 26571 & & 18290 & 6439 & & 29523 & & & 35799 & & \\
\hline 9 & 992 & 256 & & 8824 & 243 & & +33 & & & 8658 & & 24777 \\
\hline 10 & 938 & & & 32909 & 273 & & 134 & & & 6042 & & \\
\hline 11 & 3 & & & 23614 & 27734 & & 30780 & & & 32808 & & 7469 \\
\hline 12 & 128 & 27534 & 4097 & 22202 & 7997 & 11683 & 30164 & & 478 & 32009 & 23491 & 30802 \\
\hline 13 & 8175 & 8405 & 25017 & 23170 & 5830 & 7350 & 26559 & & 26436 & 30930 & 10115 & 26935 \\
\hline 14 & 233 & & 19628 & 28067 & 26801 & 38957 & 25321 & & & 31263 & 5607 & 29449 \\
\hline 15 & 716 & 5428 & 30894 & 11087 & 27684 & 36243 & 27390 & 6426 & 85 & 31282 & & 28896 \\
\hline 16 & & & & & & & & & & & & \\
\hline 17 & & & & & & & & & & & & \\
\hline 18 & 1 & & 25503 & 34994 & 273 & 258 & 30933 & & 1302 & 37829 & 277 & \\
\hline 19 & 583 & 27893 & 6655 & 26385 & 18008 & 12392 & 25599 & 24402 & 6735 & 31314 & 21326 & 29371 \\
\hline 20 & 091 & 7656 & 31739 & 24684 & 5990 & 581 & 27320 & 27114 & 32447 & 31620 & 12468 & 25166 \\
\hline 21 & 232 & 3394 & 26380 & 25176 & 28199 & 27132 & 9612 & 9516 & 27521 & 32874 & 7342 & 23627 \\
\hline 22 & 35294 & 25423 & 28344 & 10286 & 27047 & 26254 & 16352 & 9403 & 37256 & 33265 & 43083 & 20669 \\
\hline 23 & & & & & & & & & & & & \\
\hline 24 & & 29696 & & 31418 & & & 4866 & & & 7007 & & \\
\hline 25 & 3190 & 25062 & 8253 & 28508 & 37500 & 605 & 27809 & 520 & 11869 & 39588 & 20858 & 10281 \\
\hline 26 & 33390 & 20097 & 10737 & 25738 & 16534 & 7931 & 32661 & 10634 & 7092 & 32936 & 20400 & 26916 \\
\hline 27 & 26165 & 15262 & 24873 & 22574 & 9179 & 4630 & 29580 & 20701 & 26427 & 26559 & 15923 & 20957 \\
\hline 28 & 28451 & 11054 & 22226 & 22820 & 29911 & 24025 & 24452 & 8052 & 26157 & 24938 & 7232 & 21111 \\
\hline 29 & 27775 & 36473 & 19238 & 12046 & 0 & 22248 & 52769 & 7227 & 26165 & 25002 & 27206 & 21613 \\
\hline 30 & 9747 & 33383 & & 7660 & 0 & & 12659 & & 19883 & 10900 & 26529 & 23509 \\
\hline 31 & 6640 & 0 & 12688 & 25200 & 0 & 23467 & 0 & 25269 & 0 & 6789 & 23858 & 0 \\
\hline
\end{tabular}




\section{APÊNDICE F}

Tabela 19: Relação $\beta$

\begin{tabular}{|c|c|c|c|c|c|c|c|c|c|c|c|c|}
\hline \multirow{2}{*}{$\begin{array}{c}\mathbf{W} \\
\text { (DIA) }\end{array}$} & \multicolumn{3}{|c|}{ ANO DE 2004} & \multicolumn{9}{|c|}{ ANO DE 2005} \\
\hline & OUT & NOV & DEZ & JAN & FEV & MAR & ABR & MAI & JUN & JUL & AGO & SET \\
\hline 1 & 0,4246 & 0,3998 & 0,4031 & 0,4177 & 0,4213 & 0,3698 & 0,5218 & 0,4271 & 0,3718 & 0,5307 & 0,3946 & 0,5432 \\
\hline 2 & 0,3898 & 0,5909 & 0,4392 & 0,5161 & 0,5469 & 0,5090 & 0,4297 & 0,3842 & 0,4184 & 0,4560 & 0,3677 & 0,3917 \\
\hline 3 & 0,5740 & 0,4922 & 0,4713 & 0,4351 & 0,4220 & 0,5112 & 0,4126 & 0,4127 & 0,4870 & 0,5549 & 0,5037 & 0,6033 \\
\hline 4 & 0,5086 & 0,5244 & 0,5573 & 0,4260 & 0,5115 & 0,3750 & 0,4982 & 0,4810 & 0,5026 & 0,3846 & 0,4256 & 0,6165 \\
\hline 5 & 0,5238 & 0,4558 & 0,4665 & 0,4156 & 0,4810 & 0,5133 & 0,4574 & 0,4715 & 0,6317 & 0,4248 & 0,4807 & 0,4512 \\
\hline 6 & 0,5413 & 0,5169 & 0,3911 & 0,4220 & 0,4346 & 0,5406 & 0,4299 & 0,4091 & 0,4382 & 0,3934 & 0,4038 & 0,4800 \\
\hline 7 & 0,3927 & 0,5572 & 0,5413 & 0,4461 & 0,4759 & 0,5360 & 0,4572 & 0,4044 & 0,4817 & 0,5474 & 0,7456 & 0,4284 \\
\hline 8 & 0,4557 & 0,4429 & 0,5206 & 0,4573 & 0,4293 & 0,4712 & 0,4218 & 0,6665 & 0,4226 & 0,4475 & 0,3773 & 0,4672 \\
\hline 9 & 0,5496 & 0,5132 & 0,4462 & 0,5883 & 0,5414 & 0,4577 & 0,4717 & 0,4679 & 0,5106 & 0,5772 & 0,4141 & 0,4955 \\
\hline 10 & 0,3979 & 0,3801 & 0,5088 & 0,5063 & 0,4205 & 0,5279 & 0,5134 & 0,4099 & 0,4154 & 0,6042 & 0,4071 & 0,5538 \\
\hline 11 & 0,4211 & 0,3977 & 0,5945 & 0,4293 & 0,4622 & 0,4586 & 0,4735 & 0,4766 & 0,6213 & 0,5468 & 0,4365 & 0,4979 \\
\hline 12 & 0,5128 & 0,3933 & 0,4097 & 0,5551 & 0,5331 & 0,4673 & 0,5484 & 0,4147 & 0,5478 & 0,4573 & 0,4698 & 0,4107 \\
\hline 13 & 0,3757 & 0,4203 & 0,4170 & 0,3862 & 0,5830 & 0,7350 & 0,4829 & 0,4160 & 0,4807 & 0,3866 & 0,6743 & 0,4897 \\
\hline 14 & 0,3890 & 0,6168 & 0,5608 & 0,5103 & 0,5360 & 0,4583 & 0,4604 & 0,5224 & 0,3997 & 0,4168 & 0,5607 & 0,4908 \\
\hline 15 & 0,3965 & 0,5428 & 0,3862 & 0,4435 & 0,5033 & 0,5178 & 0,4565 & 0,6426 & 0,5297 & 0,5214 & 0,4075 & 0,5254 \\
\hline 16 & 0,3801 & 0,4530 & 0,3766 & 0,4637 & 0,5118 & 0,5034 & 0,5385 & 0,4009 & 0,5519 & 0,5660 & 0,4074 & 0,4056 \\
\hline 17 & 0,4280 & 0,5510 & 0,5206 & 0,4204 & 0,4828 & 0,5524 & 0,5068 & 0,4339 & 0,4067 & 0,5653 & 0,5122 & 0,4964 \\
\hline 18 & 0,4401 & 0,3755 & 0,5101 & 0,4117 & 0,4966 & 0,4699 & 0,3867 & 0,4605 & 0,4521 & 0,3783 & 0,5044 & 0,5915 \\
\hline 19 & 0,4758 & 0,3985 & 0,6655 & 0,5277 & 0,4502 & 0,4131 & 0,4654 & 0,5423 & 0,4490 & 0,3914 & 0,3877 & 0,4895 \\
\hline 20 & 0,4609 & 0,3828 & 0,5290 & 0,4937 & 0,3993 & 0,3879 & 0,4553 & 0,4930 & 0,5408 & 0,4517 & 0,4987 & 0,4194 \\
\hline 21 & 0,4359 & 0,6788 & 0,5276 & 0,5035 & 0,5127 & 0,3618 & 0,6408 & 0,6344 & 0,5004 & 0,4109 & 0,7342 & 0,4725 \\
\hline 22 & 0,4412 & 0,3911 & 0,4724 & 0,5143 & 0,4508 & 0,4773 & 0,4088 & 0,4702 & 0,4657 & 0,4158 & 0,4103 & 0,5167 \\
\hline 23 & 0,6506 & 0,4098 & 0,4498 & 0,5921 & 0,3945 & 0,4870 & 0,6185 & 0,5580 & 0,3671 & 0,5004 & 0,4616 & 0,3908 \\
\hline 24 & 0,4767 & 0,4949 & 0,5192 & 0,4834 & 0,4942 & 0,4543 & 0,4866 & 0,4169 & 0,4831 & 0,4671 & 0,4210 & 0,4973 \\
\hline 25 & 0,4493 & 0,5012 & 0,5502 & 0,5183 & 0,5000 & 0,6055 & 0,4635 & 0,4165 & 0,4748 & 0,4399 & 0,5215 & 0,5141 \\
\hline 26 & 0,4174 & 0,5024 & 0,4295 & 0,5720 & 0,4724 & 0,5287 & 0,5025 & 0,5317 & 0,7092 & 0,4391 & 0,5100 & 0,5383 \\
\hline 27 & 0,5233 & 0,5087 & 0,3827 & 0,4515 & 0,6119 & 0,9260 & 0,5378 & 0,5175 & 0,4066 & 0,5312 & 0,4549 & 0,5239 \\
\hline 28 & 0,5173 & 0,4422 & 0,4939 & 0,5071 & 0,4273 & 0,4805 & 0,3762 & 0,4026 & 0,5231 & 0,3837 & 0,4821 & 0,5278 \\
\hline 29 & 0,5555 & 0,3839 & 0,4810 & 0,4818 & 0,0000 & 0,4045 & 0,3909 & 0,7227 & 0,4361 & 0,4167 & 0,4534 & 0,3930 \\
\hline 30 & 0,4874 & 0,5136 & 0,4967 & 0,5107 & 0,0000 & 0,3961 & 0,5064 & 0,4447 & 0,3977 & 0,4360 & 0,5306 & 0,5224 \\
\hline 31 & 0,6640 & 0,0000 & 0,5075 & 0,4582 & 0,0000 & 0,4693 & 0,0000 & 0,3888 & 0,0000 & 0,4526 & 0,4772 & 0,0000 \\
\hline
\end{tabular}

